University of San Diego

Digital USD

2006-05-01

\title{
The Reluctant Sorority: Stories of American Wives of Prisoners of War and Missing in Action, 1965-1973. Lessons in Exercising Leadership in the Absence of Power
}

Steven L. Smith EdD

University of San Diego

Follow this and additional works at: https://digital.sandiego.edu/dissertations

Part of the Leadership Studies Commons

\section{Digital USD Citation}

Smith, Steven L. EdD, "The Reluctant Sorority: Stories of American Wives of Prisoners of War and Missing in Action, 1965-1973. Lessons in Exercising Leadership in the Absence of Power" (2006). Dissertations. 760.

https://digital.sandiego.edu/dissertations/760

This Dissertation: Open Access is brought to you for free and open access by the Theses and Dissertations at Digital USD. It has been accepted for inclusion in Dissertations by an authorized administrator of Digital USD. For more information, please contact digital@sandiego.edu. 
THE RELUCTANT SORORITY:

STORIES OF AMERICAN WIVES OF PRISONERS OF WAR

AND MISSING IN ACTION, 1965-1973/

LESSONS IN EXERCISING LEADERSHIP

IN THE ABSENCE OF POWER

by

STEVEN L. SMITH

A dissertation submitted in partial fulfillment

of the requirements for the degree of

Doctor of Education

University of San Diego

May 2006

Dissertation Committee

Robert Donmoyer, Ph.D.

Theresa Monroe, Ed.D.

Kenneth P. Gonzalez, Ph.D. 
(C) Copyright by Steven L. Smith 2006

All Rights Reserved

Reproduced with permission of the copyright owner. Further reproduction prohibited without permission. 


\begin{abstract}
Increasingly, political action committees and special interest groups dominate the national policy-making process. Critics charge that campaign contributions buy access to and influence with policy makers, and that the differential ability to make such contributions results in disproportional representation. The question then becomes: how do ordinary citizens who are unable to use substantial financial contributions to "purchase" access to power mobilize people to influence public policy. To state the question another way: how can people provide leadership when they possess neither positional power nor the means commonly used to influence those with positional power?

This historical study examines these questions via oral history data gathered from a group of military wives who had a significant impact in both the national and international policy arenas after their husbands became prisoners of war (POWs) or were declared missing in action (MIA) in North Vietnam between 1965 and 1973. Data from documents and letters retained by the wives also were employed to extend and triangulate interview data.

In addition, the study entailed interviewing former governmental officials, including high-ranking officials of the Nixon administration, and analyzing presidential papers held by the National Archives and accessed through the Freedom of Information Act. The major purpose of this second round of data collection and analysis was to explore linkages between the wives' actions, on the one hand, and governmental policy shifts, on the other.
\end{abstract}

The data demonstrate that the wives had a significant impact on reversing the State Department's policy of "Quiet Diplomacy" and on keeping the POW and MIA 
issue front-and-center during the Nixon Administration's peace negotiations with the North Vietnamese. The study also reveals a number of strategies that the wives used to influence public officials and that others who wish to provide leadership in the absence of formal power might employ heuristically. These strategies can be characterized as seven "lessons learned": (a) do your homework; (b) resist the organizational urge to be big; (c) tell a compelling story; (d) nothing is more important than a personal visit; (e) stay focused and remain non-partisan; (f) form partnerships, but keep partners at arms-length; and, (g) don't get "slick"/avoid public relations professionals. 


\section{Dedication}

To my wife, Tempest, for your patience and support

To my children, Aubrie, Summer, Jordan, for your inspiration

To the POW and MIA wives, for your remarkable courage and resolve 


\section{Acknowledgements}

My interest in American POW and MIA matters began in the late 1960s when I remember seeing a bamboo prison cage in a grocery store parking lot. The display was advertising the type of inhumane treatment American POWs in South and North Vietnam were receiving. Like so many from that era, I too remember the POW and MIA bracelets, bumper stickers, and the general concern over POW and MIA matters. In early 1973, I watched the television coverage of the return of the POWs to American soil, which was a national celebration. In May 1973, Colonel Robbie Risner, USAF, spoke at my high school graduation class breakfast. After 1973, I read several books written by American prisoners held captive by the North Vietnamese in Hanoi. In 1996, while on active duty in the United States Navy, I conducted the burial at sea service for Captain Harry Jenkins, POW, 1966-1973, from the flight deck of USS DENVER (LPD 9). Though it is not naval policy, the Navy made an exception to its rule to permit Captain Jenkins' two sons and his bother to join the crew and assist in the burial. During one of our conversations I had with the sons, they spoke about their mother's experience and her difficult days as a POW wife. They spoke with admiration, respect, and a sense of awe of what their mother had endured.

Even though I had read Vice Admiral James B. and Sybil Stockdale's book, In Love and War, over ten years earlier, I reread it with my eyes focused on Sybil's story. Soon I realized, as the literature review shows, that though there are hundreds of books and thousands of articles written by and about the men, there was a dearth of material by or about the wives, as well as the mothers and fathers who were highly active in the national and international political arena. 
I am well aware that those directly living the experience might challenge or debate portions of the story or my findings, I take full responsibility for the interpretation of the data, its organization, the findings, and resultant conclusions. However, the reader must bear in mind my overall desire was, with a shadow of illumination, to focus on a period of history where a group of women were key and significant players in the policymaking process.

I want to acknowledge the work of Bob Donmoyer, who endured long hours of work and discussion. Most importantly, he believed in the project, and understood its historical importance and current relevance to a number of academic studies. Also, I want to thank Terri Monroe for her remarkable teaching and coaching style that has made me a better person and helped me to see events from different perspectives. For Ken Gonzalez, who helped me to see the implications of this study and its relation to other disciplines. To Bev Callaway, for your patience and perseverance in editing. To Beth Yemma, thank you for all the emails to keep me on track and all the administrative support. To Mike Hogg, a servant of servants and trusted friend, who convinced me to apply to the USD program; Frank "Soupy" Sailes, a man who knew the inferno of battle from the cockpit, a great office-mate who encouraged me to persevere to the end; and to Dr. Edie Eger, a survivor herself, who threw her support behind my endeavors. To my Navy Cohort: We each began the program with hopes, dreams, and aspirations. In the midst of professionally demanding jobs, which often times took us to foreign shores for extended periods, we nonetheless continued with the program and our own journeys. I cannot thank you enough for your support, encouragement, discussions, insight, and friendship. 
I owe a debt of sincere gratitude to Mr. Melvin Laird, Mr. Robert Dole, Mr.

Richard Capen, Mr. Alexander Butterfield, and Mr. Al Haig, Jr., for their willingness to participate in this project by granting an interview or providing personal correspondence to a series of questions. These men have served the American people in elected or appointed positions in our government and are deserving of respect and admiration for their commitment to the greater good.

Special and Significant Appreciation

- In Honor -

Karen Butler

Husband captured on April 20, 1965, returned on February 12, 1973

Jenny "Connell" Robertson

Husband captured on July 15, 1966, died in captivity, negotiated remains returned

Sandy Dennison

Husband captured on July 19, 1966, died in captivity, negotiated remains returned

Marie Estocin

Husband shot down on April 26, 1967, officially listed as MIA, POW, then KIA

Phyllis Galanti

Husband captured on June 17, 1966, returned on February 12, 1973

Marty Halyburton

Husband captured on October 17, 1965, returned on February 12, 1973

Sherry Martin

Husband captured on July 9, 1967, returned on March 4, 1973 


\section{Chloe Moore}

Husband captured on March 11, 1967, returned on March 4, 1973

Bonnie Singleton

Husband captured on November 6, 1965, returned on February 12, 1973

Shirley Stark

Husband captured on May 19, 1967, returned on March 4, 1973

Sybil Stockdale

Husband captured on September 9, 1965, returned on February 12, 1973

Alice Stratton

Husband captured on January 5, 1967, returned on March 4, 1973

Mary Winn

Husband captured on August 9, 1968, returned on March 14, 1973 


\section{Contents}

CHAPTER ONE: LEADERSHIP IN THE ABSENCE OF POWER: THE STORIES OF AMERICAN WIVES OF PRISONERS OF WAR AND MISSING IN ACTION IN VIETNAM, 1965-1973

BaCkgRound to THE STUdy/Statement Of THE Problem .........................................

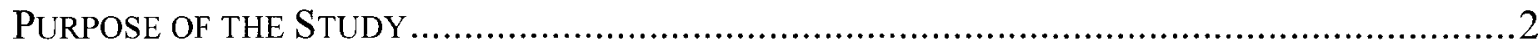

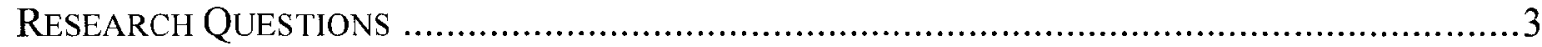

CHAPTER TWO: REVIEW OF RELATED LITERATURE ......................................4

Literature Associated with Participation in the Policymaking Process ................5

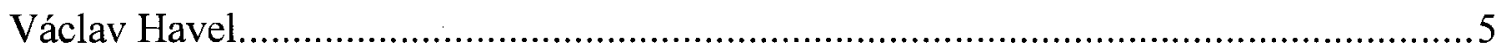

Charles Lindblom and Edward Woodhouse .......................................................

John Kingdon ............................................................................................. 11

Margaret Placier, Peter Hall, Sherron McKendall, and Karen Cockrell ........................ 15

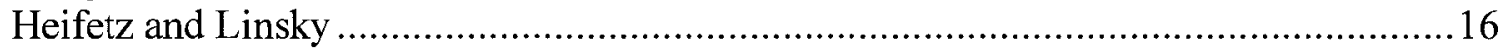

LITERATURE ABOUT VIETNAM POW AND MIA WIVES ..............................................20

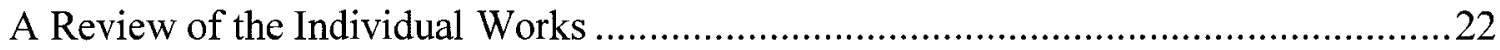

Cross-Cutting Themes in the Literature About POW and MiA Wives .....................34

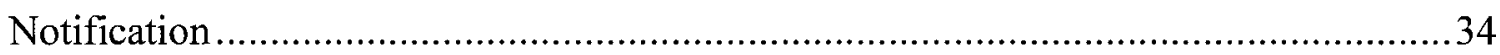

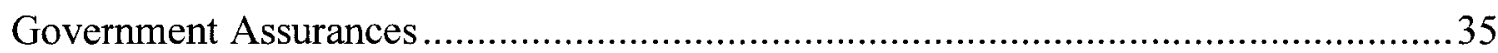

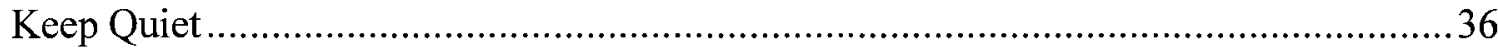

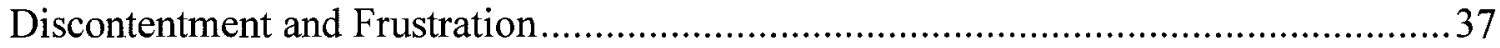

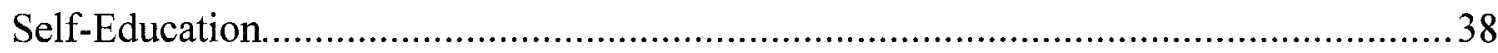

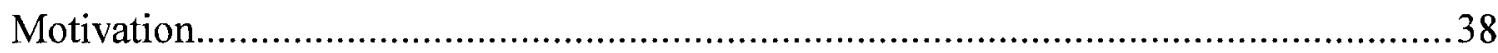

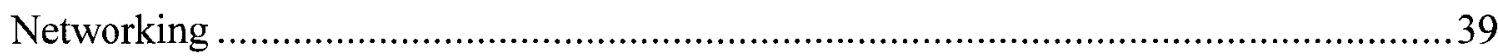

Contacting Elected and Appointed Officials .................................................40

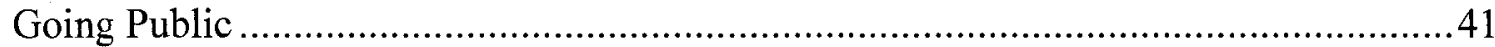

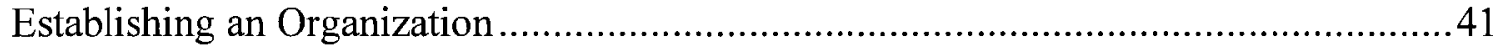

Publicizing the POW/MIA Issue on a National Scale.............................................43

Disagreement Within the League............................................................44

Years of Work Take a Toll: Exhaustion.............................................................45

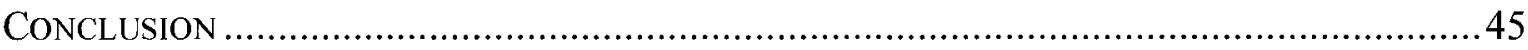

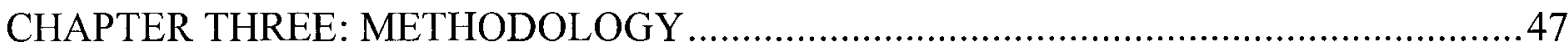

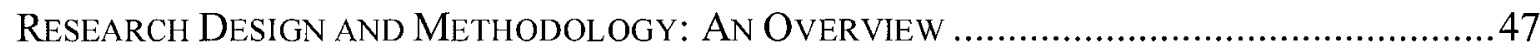

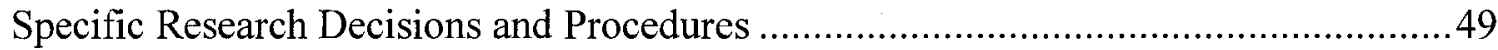

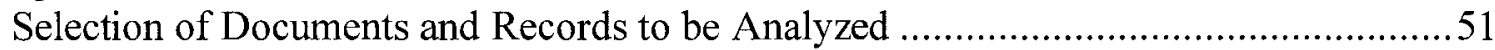

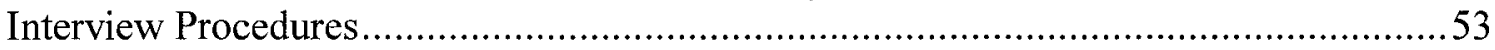

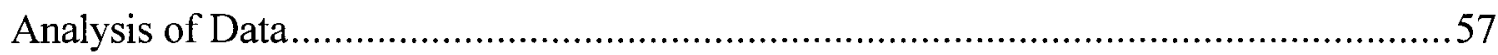

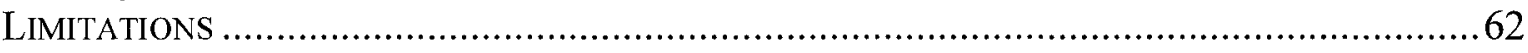

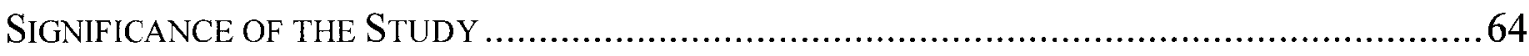

CHAPTER FOUR: THE RISE OF THE RELUCTANT SORORITY ...............................65

REKINDLING OF SUPPORT AND REMEMBRANCE OF PAST DAYS......................................65

Historical CONTEXT OF THE Prisoner of WAR AND Missing IN ACTION ISSUE.............68

xii 


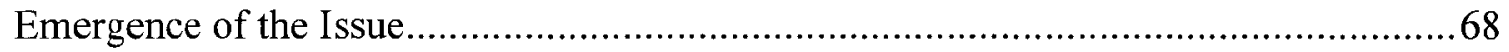

The Cultural Context and Women's Roles .............................................................. 70

The Government's Prisoner of War Policy: Whose Policy Is It, Anyhow?......................74

Geneva Convention Relative to the Treatment of Prisoners of War...............................77

Changing Status, Stark Realizations, AND ReQuisite AduUstments.........................79

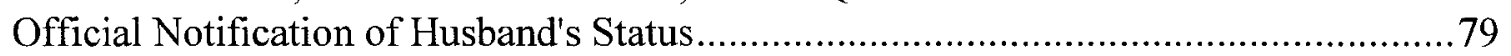

A Common Remembrance: The Keep Quiet Policy .................................................82

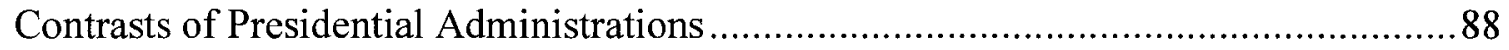

Personal Motivation for Involvement with the POW and MIA Issue.............................91

Politicians, APPoINTEes, AND THE AMERICAN Public ATtITUde ...................................93

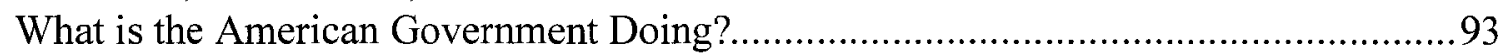

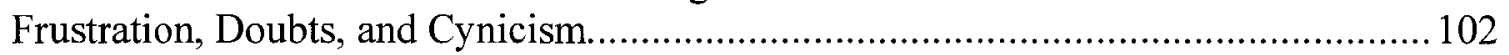

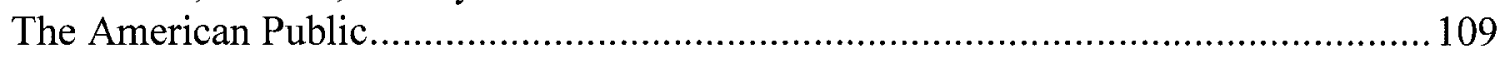

CHAPTER FIVE: ADAPTING TO THE CHALLENGE-FROM INFORMAL

RELATIONSHIPS TO A FORMAL ORGANIZATION ................................................ 114

Establishing SuPport, NETWorking, AND DEVELoPING AN AGENDA..........................114

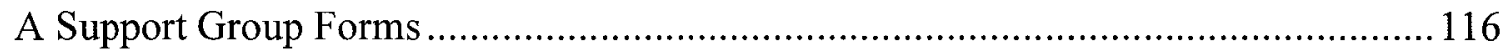

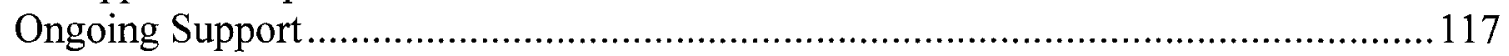

Support for Those Who Lived Outside of San Diego ...............................................119

From Support Group to Limited Political Activism …………................................... 121

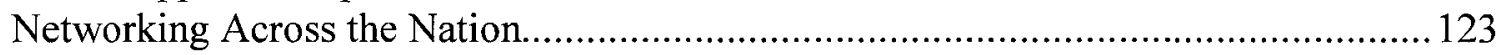

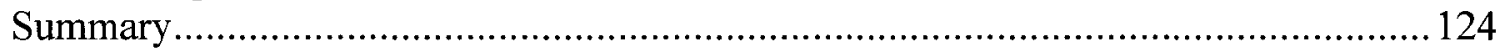

MAINTAINING APPROPRIATE BEHAVIOR WITH GOVERNMENTAL OfFICIALS.......................125

INFLUENCING THE GOVERNMENTAL POWER STRUCTURES..............................................128

Personal Contact Becomes an Imperative …………............................................ 128

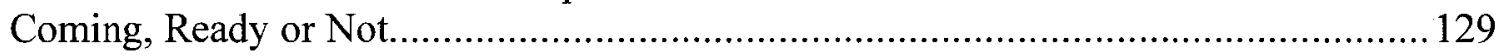

Another Reason for Contact …………..............................................................130

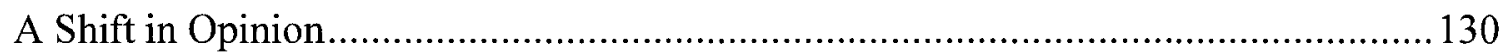

CHAPTER SIX: DEVELOPING AN ORGANIZATION FOR EXPOSURE OF THE

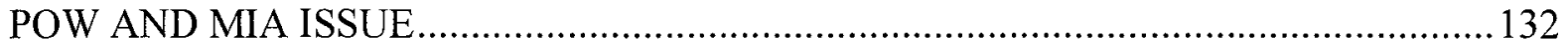

The League of Wives of American Vietnam Prisoners of War becomes, The National League of Families of American Prisoners in Southeast Asia, which Becomes, The National League of Families of American Prisoners and Missing

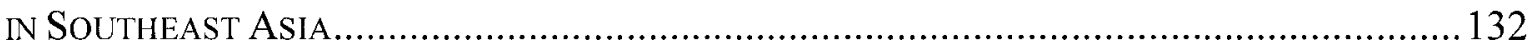

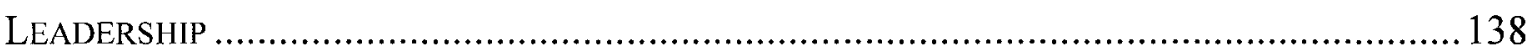

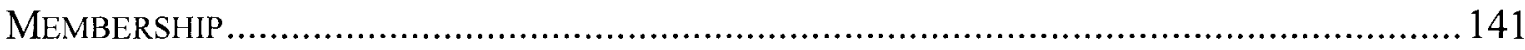

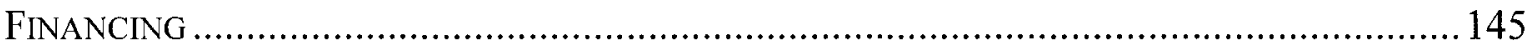

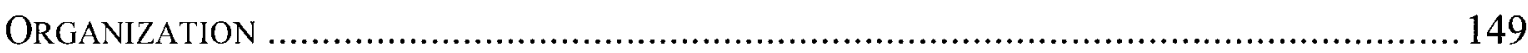

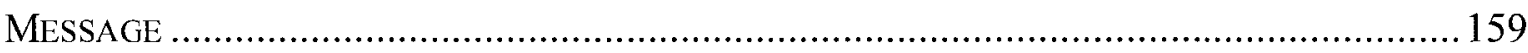

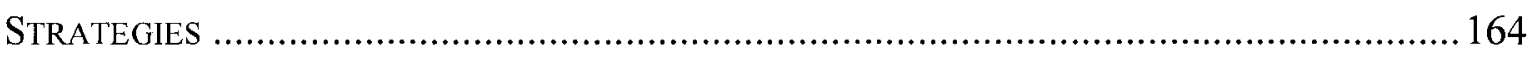

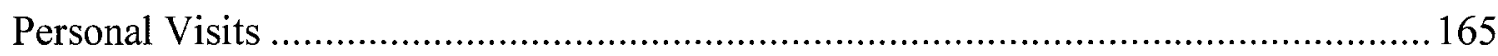

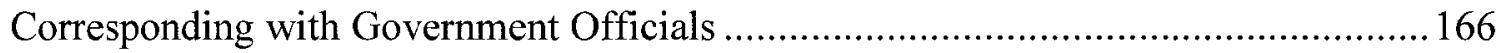

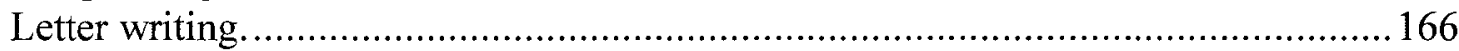

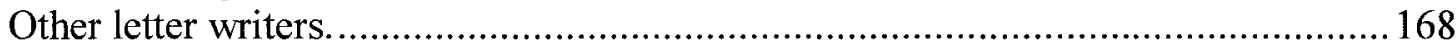

A unique approach to contacting government officials: the "telegraph-in.".............. 169

xiii 


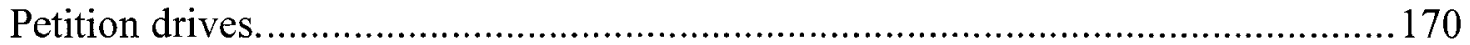

Corresponding with world leaders...............................................................171

Communicating with government officials indirectly rather than directly ................172

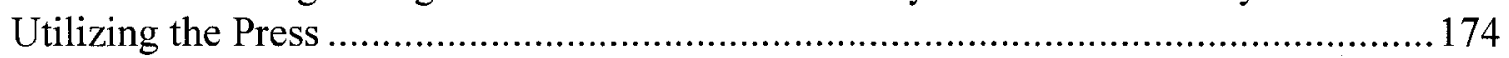

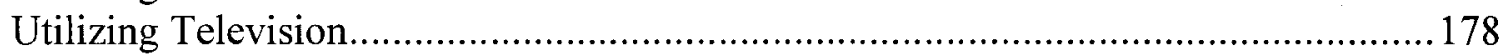

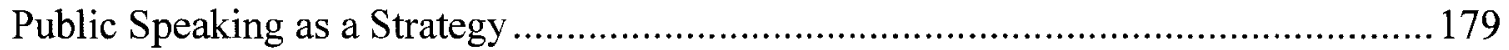

Refraining from Partisan Politics and Taking a Position on the War ...........................184

Working With (and, in Some Cases, Helping to Form) Affiliated Groups...................188

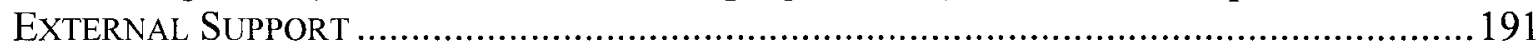

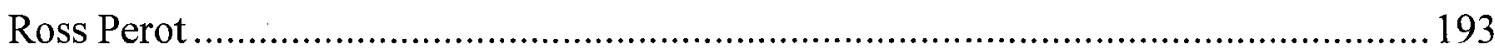

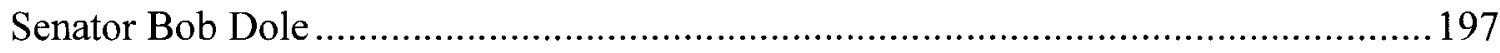

Other External Support: The National Advertising Council's Campaign ....................200

Putting External Support in Context ...................................................................2202

Bold Maneuvers: The National League Becomes a Player on the World Stage ...........203

CHAPTER SEVEN: THE UNITED STATES GOVERNMENT RESPONDS ...................210

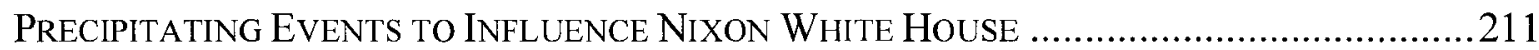

The League of Wives Telegraph-In .......................................................................211

The League of Wives Official Request to Meet with Nixon .......................................215

Capital Hill Visits and the Congressional Record ................................................219

A Defining Moment: Secretary of Defense Melvin Laird Goes Public and

SHIFT'S THE GOVERNMENT'S POW AND MIA POLICY ……….....................................222

Melvin Laird: The Reluctant Secretary of Defense .................................................222

Richard Capen: A Second Ally in the Department of Defense ....................................223

Laird's Publicly Announces a Change in POW and MIA Policy ................................225

The Washington Road Show Rolls Again!..............................................................228

So, What Did the Wives Play in Laird's Decision to Reverse the Quiet Diplomacy

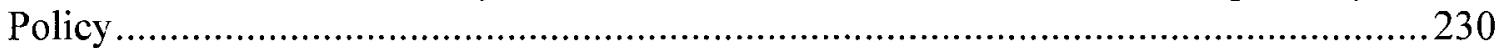

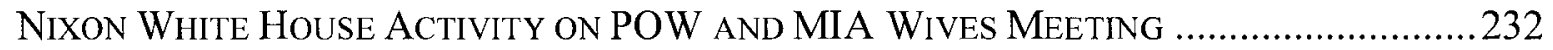

White House Considers Plans for POW and MIA Wives to Meet with the President...235

Internal White House's Debate over the Proposed Visit ..........................................236

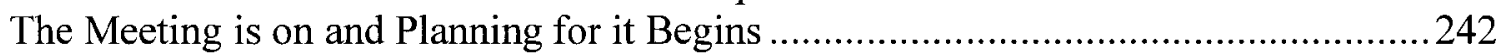

President Nixon Meets with POW and MIA Wives and Mothers ..............................248

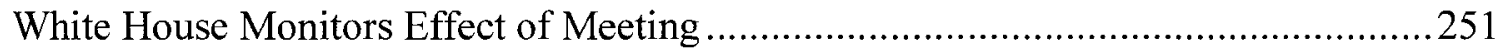

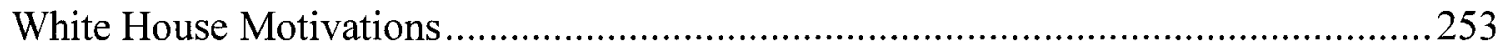

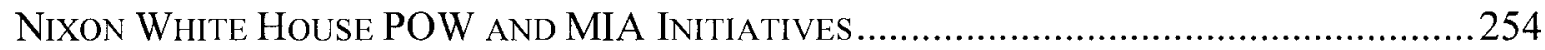

White House Develops Propaganda Offensive for POW and MIA Issue ......................254

White House Includes POW and MIA Issue into War Settlement ..............................261

White House Ability to Influence Support...............................................................265

Attention Must be Paid! The Wives Interactions with the President and

OTHER White House OfFicials IN THE EARLy 1970s ................................................268

The Multiple Meanings of Meetings with White House Officials.................................268

Nixon and Laird Speak at a National League Convention ..........................................273

The National League Demands/the Administration Responds: The Formation of the

Non-Partisan Political Action Committee ..................................................................2275

President Nixon Meets with National League Leadership .........................................282 
NiXON'S SUPPORT OF THE POW AND MIA ISSUE IN THE EARLY 1970s ..........................285

Pressure to KEEP THE POW AND MIA ISSUE ON THE AGENDA ..................................28

The Bottom Line Question: What Difference Did the Wives Make? ....................291

CHAPTER EIGHT: A PERSONAL POSTSCRIPT - THE PSYCHOLOGICAL TOLL OF EXERCISING LEADERSHIP IN THE ABSENCE OF POWER ............................. 296

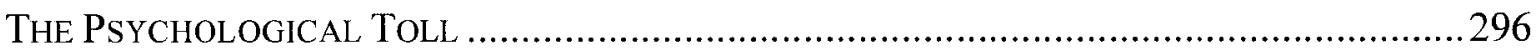

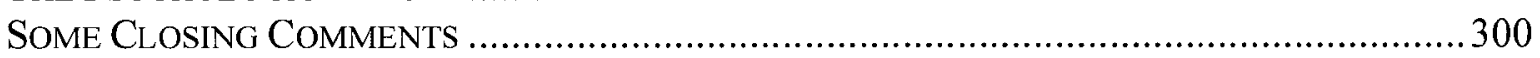

CHAPTER NINE: DISCUSSION AND RECOMMENDATIONS ..................................301

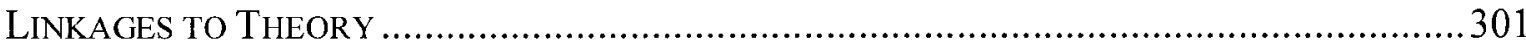

Linkages to Ronald Heifetz's Leadership Without Easy Answers...............................302

Linkages to Heifetz and Linsky's Leadership on the Line ...................................... 304

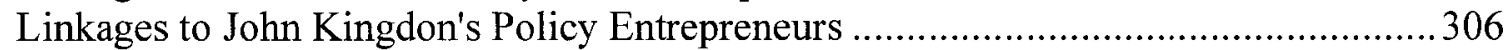

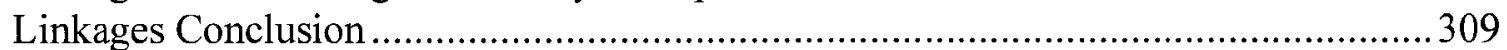

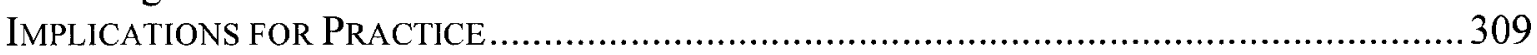

Lesson \# 1: Do Your Homework ........................................................................ 310

Lesson \# 2: Size Matters; Resist the Organizational Urge to be Big .......................... 311

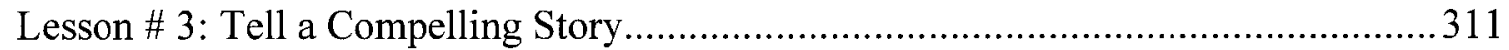

Lesson \# 4: Nothing is More Important than a Personal Visit .................................. 312

Lesson \# 5: Stay Focused/Remain Non-Partisan ................................................... 312

Lesson \# 6: Form Partnerships, but Keep Partners at Arms-Length.............................313

Lesson \# 7: Don't get Slick/Avoid Public Relations Professionals ...........................313

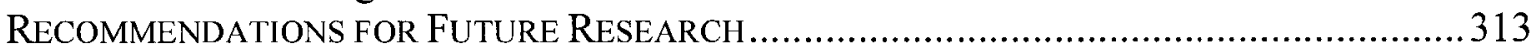

Studies of Other Influential Individuals or Groups on the POW/MIA Issue ................ 314

Studies of Other Groups That Have Exercised Leadership on Other Public Policy

Issues in the Absence of Positional Power/Constructing Grounded Theory..................314

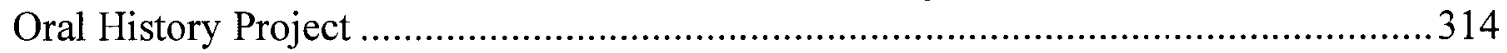

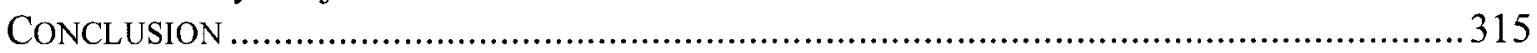

APPENDIX A PARTICIPANT CONSENT FORM .............................................. 316

APPENDIX B SURVEY QUESTIONNAIRE: POW AND MIA WIVES ......................318

APPENDIX C SURVEY QUESTIONNAIRE: GOVERNMENT OR MILITARY

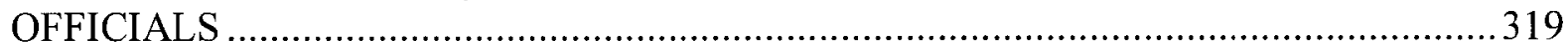

APPENDIX D GENEVA CONVENTION ARTICLES RELATIVE TO THE TREATMENT OF PRISONERS CITED BY WIVES …......................................320

APPENDIX E ADVICE TO POTENTIAL PRISONER OF WAR FAMILIES.................322

APPENDIX F ADDITIONAL REFERENCES ON INHUMANE TREATMENT OF THE PRISONERS................................................................................ 324

APPENDIX G HOW TO HANDLE YOUR CONTACTS WITH THE MEDIA................325 
APPENDIX H REMARKS OF THE PRESIDENT AT THE ANNUAL MEETING OF THE NATIONAL LEAGUE OF FAMILIES OF AMERICAN PRISONERS AND MISSING IN SOUTHEAST ASIA

APPENDIX I ADDRESS BY THE HONORABLE MELVIN R. LAIRD 329

APPENDIX J NATIONAL WEEK OF CONCERN FOR AMERICANS WHO ARE PRISONERS OF WAR OR MISSING IN ACTION

BIBLIOGRAPHY .335 
Chapter One: Leadership in the Absence of Power: The Stories of American Wives of Prisoners of War and Missing in Action in Vietnam, 1965-1973

\section{Background to the Study/Statement of the Problem}

Leadership Studies scholars increasingly suggest that leadership should not be equated with positional power or formal authority derived from an organizational structure. Nor should it be viewed as a set of personal characteristics. For example, in his seminal work, Leadership without Easy Answers, Ronald Heifetz writes, "We ought to focus on leadership as an activity - the activity of a citizen from any walk of life mobilizing people to do something." ${ }^{1}$ Heifetz warns that "by restraining the exercise of leadership to legitimate authority, we also leave no room for leadership that challenges the legitimacy of authority or the system of authorization itself... [yet] social progress may require that someone push the system to its limit."

Except for Ronald Heifetz, most leadership scholars focus on organizational issues rather than large-scale policy issues. The result of this is a limited amount of work in the leadership studies field that systematically explores how individuals without formal positional power and who lack the resources to literally buy access to power can exercise leadership in a national policymaking context. Even in the field of political science, studies of the policy making process tend to focus on well established interest groups that normally are represented by formal organizations and professional lobbyists.

There is a need, therefore, to begin to examine the exercise of leadership in the public policy domain by individuals and groups that have neither formal positional power

${ }^{1}$ Heifetz, Leadership Without Easy Answers, 20. 
Chapter One

nor the sorts of resources that normally are used to influence those with formal policy making authority. This study responded to this need.

\section{Purpose of the Study}

The purpose of this study was to increase understanding of how citizens without formal positional power can provide leadership in the national policymaking context and, in fact, influence the policies that get adopted and implemented. Specifically, this study focused on how a group of military wives became significant players in the national and international policy contexts after their husbands became prisoners of war (POW) or were declared missing in action (MIA). This group was especially appropriate to study since, as this study documents, the wives had a significant impact on policy within both the national and international policy arenas, even though they entered these arenas with neither formal positional power nor the sorts or resources that traditionally are associated with influencing those with positional power.

To accomplish its more general goals, the study focused on three more specific interrelated goals: (a) gather and configure life history data from POW and MIA wives, with a particular focus on their individual and collective activities on the POW and MIA issue; (b) triangulate the women's stories with documents such as letters, newsletters, and newspaper accounts that focused on the women and the organization they eventually formed, the National League of Families; and (c) document the impact that the women and their organization had on public policy through interviews with former high-ranking officials and a review of documents held by the National Archives and Records Administration (NARA) and accessed through the Freedom of Information Act.

\footnotetext{
${ }^{2}$ Ibid., 21.
} 


\section{Research Questions}

The purposes that were articulated in the prior section can be distilled into the following three research questions:

- What triangulated stories do the women tell about their experiences and the strategies they employed?

- What do former high ranking government officials and archived government documents say about the policy impact of the women and their organization?

- What insights do the interview data and the document analysis provide about exercising leadership in the policy arena when one has neither formal positional power nor the sorts of resources that normally are used to gain access to and influence those with formal policymaking authority?

\section{Overview of the Dissertation}

The next chapter reviews literature that is relevant to the study being reported here. Chapter 3 describes the research methods employed in the study. Chapters 4 through 8 are findings chapters. The first three of these chapters document the evolution of the womens' political activities; chapter 7 looks at the women's activities from the perspective of government officials and explores the actual impact the women's actions had on policy; and chapter 8 is a kind of postscript about the emotional toll on the women. The concluding chapter, Chapter 9, is organized around three tasks: (a) linking the findings of this dissertation study with relevant theory; (b) explicating specific strategies the women used to influence public policy that could be used heuristically by others who wish to exercise leadership in the absence of positional power; and (c) discussing implications of this study for further research. 
The literature on leadership has increasingly suggested that leadership should not be equated with positional power or legitimate authority derived from a social structure. Nor should the concept be limited to a set of personal characteristics that determine the qualification or competence of an individual to lead. In his book, Leadership Without Easy Answers, in fact, Ronald Heifetz wrote, "Leadership is an activity-the activity of a citizen from any walk of life mobilizing people to do something. ${ }^{3}$ Except for Ronald Heifetz, most leadership scholars focus on organizational issues rather than large-scale policy issues. Literature on how individuals without formal positional power or institutional legitimate authority can exercise leadership in a national policymaking context must be gleaned from literature in fields other than Leadership Studies. Even much of the literature in these fields has limitations, however.

In the field of political science, for example, studies of the policymaking process tend to focus on established interest groups that normally are represented by formal organizations and professional lobbyists. According to Heifetz, this is problematic: "By restraining the exercise of leadership to legitimate authority we also leave no room for leadership that challenges the legitimacy of authority or the system of authorization itself. ... [S]ocial progress may require that someone push the system to its limit." Gary Hart, a former politician, made much the same point in his book, Restoration of the Republic. He wrote, "Civil, legal, and political rights are most in jeopardy . . . when government

\footnotetext{
${ }_{4}^{3}$ Heifetz, Leadership Without Easy Answers, 20. Ibid., 21.
} 
becomes detached and remote from the citizenry, when elected representatives fall under the sway of interests, when the concerns of the powerful, usually commercial, elites outweigh the common good in the halls of power, and when individual citizens lose their sense of participation in the public life of the community and nation."

Part of what Hart grapples with is the perplexing question of how ordinary citizens can effectively participate in a democracy. That question, of course, is the underlying question of this dissertation. Because this dissertation focused on documenting the impact that a specific group of military wives had on the policymaking process and surfacing the strategies that they employed to have an influence, it seemed prudent to not only review literature produced by or about the wives but also to examine other, more general literature about citizen participation in the policymaking process. These discussions can provide insight into the policymaking process, in general, and how people devoid of legitimate authority or positional power can work to influence the system and process, in particular. This sort of insight can serve as a theoretical backdrop for the five findings chapters that make up the bulk of this dissertation.

Thus, the first part of this chapter focuses on literature about political participation. The second part focuses more directly on literature about the Prisoner of War and Missing in Action issue during the Vietnam ear.

\section{Literature Associated with Participation in the Policymaking Process}

\section{Václav Havel}

In his seminal essay, Power of the Powerless, Václav Havel examined the potential of the powerless under "the dictatorship of a political bureaucracy" in

5 Hart, Restoration of the Republic, 15. 
Chapter Two

Czechoslovakia during the 1970 s. ${ }^{6}$ Havel's work is important because his basic argument derives from a philosophical premise about the subtle destructiveness of citizenry apathy and conformity in the face of an institutionalized ideology. Furthermore, Havel raised two pivotal questions regarding citizenry involvement in the existing dictatorial political system. First, "Is it within the power of the 'dissidents' - as a category of subcitizen outside the power establishment - to have any influence at all on society and the social system?" Second, "can they actually change anything?"?

Havel's essay is constructed around a concert example: the greengrocer who dutifully exhibits the required political sign, with its governmental sanctioned slogan, in his shop's window. The greengrocer's behavior and act of obedience to the power of the socio-political hierarchy, as Havel argues, is not done to promote the truth or validity of a slogan. For the greengrocer, the words contained in the slogan are not his real opinion. Rather, the greengrocer accepts the "prescribed ritual, by accepting appearances as reality, by accepting the given rules of the game." ${ }^{8}$ To do otherwise is to be excluded, isolated, and alienated from workers and society, loosing peace, tranquility, and security. The greengrocer's behavior, therefore, supports and is at least tolerant of the power based socio-political rules. The result, writes Havel, is that the greengrocer "must live within a lie. ${ }^{19}$

Havel goes on to ask what the impetus is for a citizens not to succumb "to a profane trivialization of his or her inherent humanity, and to utilitarianism" in a regime

${ }_{7}^{6}$ Havel, Power of the Powerless, 24.

${ }_{8}^{7}$ Ibid., 23.

Ibid., 31 .

Ibid., 31 
Review of the Related Literature that is built on coercion and requires conformity of its citizens? ${ }^{10}$ Havel answered this question by further developing the story. Havel wondered what would happen if the greengrocer rebels, rejects his part in the prescribed ritual, and decided to break the rules by not placing the slogan in the shop's window? What if he began to state honest thoughts at political meetings as well as align himself with those his conscience could support? What if he began to "live within the truth"?

Havel noted the consequence of such action would be readily dealt with by those in powerful political positions. The greengrocer would lose his management position, be transferred to a menial job with limited influence, harassed by superiors, experience a pay cut and cancellation of his vacation, and find that his children would not receive a higher education. Havel contended that those who enforce the penalties for the greengrocer's disobedience do so, not out of personal conviction, but under pressure from the regime authorities that are nothing more than agents of the political bureaucracy automatism. ${ }^{12}$ The enforcers also live and act out a lie, in other words. Thus deciding to live within the truth, Havel contended, has the potential for "incalculable political power."

Havel went on to develop the view that powerless people, when living in the truth, possess significant amounts of power to influence the system. He noted, for example, that ultimately, power is immaterial and resides within an individual. The ultimate confrontation between the powerful and the powerless, he wrote, "does not take place on the level of real, institutionalized, quantifiable power which relies on the various instruments of power, but on a different level altogether: the level of human

$$
\begin{aligned}
& { }_{11}^{10} \text { Ibid., } 38 . \\
& { }_{11} \text { Ibid., } 39 . \\
& { }_{12} \text { Ibid., } 39 \\
& \text { Ibid., } 41 .
\end{aligned}
$$




\section{Chapter Two}

consciousness and conscience, the existential level." ${ }^{14}$ Based on this understanding, Havel contrasted observable power with power that is unseen and unexpected.

Ultimately, according to Havel, power does not reside in the strength of definable political or social groups, but chiefly in the strength of a potential, which is hidden throughout the whole of society, including the official power structures of that society. This more subtle form of power does not participate in any direct struggle for power; rather it makes its influence felt in the obscure arena of being itself.

Thus, Havel's philosophy for political engagement is rooted in a belief in truth and a sort of existential revolution that quicken the hearts, minds, and souls of citizens. Coupled with these beliefs is a vision of a new form of government. According to Havel, governmental structures need to be open, relatively small, dynamic, and rooted in shared common community feelings; in short, they must be the antithesis of structures that are rigidly hierarchical. This new political environment, according to Havel, would lead to the rehabilitation of "values like trust, openness, responsibility, solidarity, [and] love." ${ }^{15}$

Havel also opposed the "strategic agglomeration of formalized organizations." He preferred organizations that sprang up ad hoc, because they were more likely to be "infused with enthusiasm for a particular purpose and disappearing when that purpose had been achieved." ${ }^{17}$ Additionally, Havel believed that organizations should be rooted in the shared experiences and personalities of their members.

In many respects, the world Havel inhabited (and which influenced his thinking)

\footnotetext{
${ }_{15}^{14}$ Ibid., 41. ${ }_{16}^{15}$ Ibid., 93 .

Ibid., 93.

Ibid., 93 .
} 
was radically different from the world inhabited by the women who are the focal point of this dissertation. Yet there are also intriguing similarities. In the early years, for example, the women were forced to live their own version of the lie Havel writes about as they acquiesced to a government policy that they increasingly believed was wrong. They also formed the sort of personal organization that Havel touts as the best form of government and used the power of this personal organization to impact more formal governmental structures (a possibility that Havel's somewhat utopian view of government does not really explore). Thus, despite the seemingly different contexts in which Havel and the women who were the focal point for this study worked, elements of Havel's thinking often can be quite comfortably layered on to the wives' experiences. Readers are encouraged to think of Havel's ideas as they read the women's story recounted in Chapters 4 through 9.

\section{Charles Lindblom and Edward Woodhouse}

Like Gary Hart and Václav Havel, Charles Lindblom and Edward Woodhouse appeal for the policy process to be inclusive of all citizens. Indeed, they wrote, "We suggest that helping ordinary people to think more clearly about social problems and possibilities is the best hope for shaping a better world." ${ }^{18}$ In addition, they advocate for "rethinking and changing power relations to better promote the intelligence of democracy." 19

According to Lindblom and Woodhouse, the rethinking process must begin with reconsidering terminology. They argue that traditional terminology--terms such as

\footnotetext{
${ }_{19}^{18}$ Lindblom and Woodhouse, Policy Making Process, viii.

Ibid., viii.
} 


\section{Chapter Two}

"leader"- unduly limit our thinking about political participation and the policymaking process in general. "It is misleading to refer to those in positions of authority as 'the policy makers' or 'leaders' or 'decision makers, ${ }^{\prime \prime 2}$ they write, since policy is the product of a wide array of forces operating in often-serendipitous ways. Therefore, what citizens have learned about the political process must be unlearned so the focus is not "excessively on government officials," who all too often makes citizens dependent and confined to an institutional structure.

In order to bring about greater citizen participation, Lindblom and Woodhouse prefer the use of the term functionary for those performing an official function in relation to the policy process. Altering the language we use to discuss the policymaking process, they believe, will facilitate a needed perspective change that promotes and endorses citizenry involvement in the policymaking process.

Lindblom and Woodhouse go on to argue that elections provide exceedingly limited opportunities for citizen participation and that these opportunities do not necessarily translate the needs and convictions of voters into policy that is consistent with citizen's needs and wishes. Forms of participation other than voting are required for government officials to respond adequately to citizens' needs and concerns.

Lindblom and Woodhouse, however, are not naïve; they acknowledge that power, position, elitism, economic status, as well as other inequitable influences often mitigate citizenry advocacy. Nonetheless, they are convinced that problematic societal issues are best dealt with by improving the thinking of ordinary citizens, and they argue that the

$$
\begin{aligned}
& { }^{20} \text { Ibid., } 4 . \\
& \text { Ibid., } 4 .
\end{aligned}
$$


development of critical thinking by the public is contingent on policy professionals allowing for the articulation of competing ideas and diverse recommendations for addressing social problems.

A major criticism of the Lindblom and Woodhouse book is that it is exceedingly short on specifics about what ordinary citizens can actually do to influence the political process. Even the claim that the public's thinking ability can be improved if policy professionals encourage the articulation of competing ideas can seem like wishful thinking, especially in this age of mass-media manipulation. Thus, this dissertation has the potential to add a degree of concreteness to the good intentions on display in The Policy Making Process by describing the strategies a group of citizens actually used to introduce ideas that were not initially sanctioned by government officials into the public discourse. This topic will be revisited in the final chapter of this dissertation, after the findings from the study have been presented.

\section{John Kingdon}

John Kingdon's Agendas, Alternatives, and Public Policies outlines a theoretical framework that brings a degree of rationality and order to a process that can often seem disjointed and chaotic. Even as he did this, however, Kingdon acknowledged the limitations of his work due to the fact that the area of policy development is "particularly untidy." ${ }^{22}$

Despite the untidiness of the phenomena_or, arguably, because of it_-Kingdon considers precision in the use of terms and concepts essential for developing understanding. Thus, he defines one of his key terms, agenda, as follows: "The agenda,

${ }^{22}$ Kingdon, Agendas, Alternatives, and Public Policies, 2. 


\section{Chapter Two}

as I conceive of it, is the lists of subjects or problems to which governmental officials, and people outside of government closely associated with those officials, are paying some serious attention at any given time. So, the agenda-setting process narrows this set of conceivable subjects to the set that actually becomes the focus of attention. ${ }^{23}$

In order to unpack the public policy process, Kingdon identified two categories that potentially influence the agenda and its alternatives: the participants and the processes that lead to an issue receiving attention. He divides participants into two broad categories: those within government and those outside of government. This distinction, of course, is relevant to this dissertation. Chapters $4,5,6$, and 8 focus on a small group of women who clearly belong to the latter group; chapter 7 focuses on the former group, including the President of the United States and his senior officials. More specifically, the dissertation focuses on how the latter group managed to make its agenda a part of the agenda of government officials, including the President.

According to Kingdon's research, a government official such as the President "may be able to dominate and even determine the policy agenda, but is unable to dominate the alternatives." ${ }^{24}$ In spite of this, top government officials such as the President still have means to influence the agenda setting process through such things as Presidential vetoes and the ability to hire and fire staff to maintain organizational unity. Additionally, high-ranking government officials such as the President have a significant ability to command the attention of the public, especially if they maintain their popularity.

$$
\begin{aligned}
& { }_{23}^{23} \text { Ibid., } 3 . \\
& \text { Ibid., } 23 .
\end{aligned}
$$


Outside the government, Kingdon considers "interest groups, researchers, academics, consultants, media, parties and other elections-related actors, and the mass public" to be key actors in the agenda setting process. ${ }^{25}$ The single most important distinction between those inside the government and those outside is that of formal authority. Those within the government have it; those on the outside do not.

Despite their lack of formal power, however, Kingdon observed that, at times, "interest group pressure does have a positive impact on the government's agenda, and does so with considerable frequency. A group that mobilizes support, writes letters, sends delegations, and stimulates its allies to do the same can get government officials to pay attention to its issues." ${ }^{26}$ The problem for interest groups, according to Kingdon, is that they lose the ability to completely control the discussion, agenda, and alternatives as the process proceeds. What interest groups do have in their favor, however, are the resources they bring to bear on the issue. Some groups with geographical dispersion have the "ability to mobilize their members and sympathizers: and their numbers, status, or wealth—are thought to have an ability to affect election outcomes." ${ }^{27}$ Furthermore, if a group convinces governmental insiders that their organization speaks with one voice, there is a greater likelihood that it will influence the policymaking process.

Furthermore, Kingdon argues that problems help establish an agenda. Problems, however, are not always apparent to the whole of society or to governmental officials. But problems are often thrust into the forefront as a result of one of the three elements: when a crisis or disaster of some proportion occurs; when an issue becomes defined by a

$$
\begin{array}{r}
{ }_{26}^{25} \text { Ibid., } 45 . \\
{ }_{27} \text { Ibid., } 49 . \\
\text { Ibid., } 51 .
\end{array}
$$




\section{Chapter Two}

powerful symbol that has mass appeal; or when a policy maker utilizes his or her personal experience. ${ }^{28}$ Kingdon does not discuss which of these has the greatest impact on the groups he studied. However, he emphasized the ability of a symbol to focus attention and capture reality because it provides visual understanding and comprehension to the masses.

A significant element of Kingdon's research is his discussions about "policy entrepreneurs." ${ }^{29}$ Policy entrepreneurs have one defining characteristic: "[a] willingness to invest their resources - time, energy, reputation, and sometimes money - in the hope of a future return." ${ }^{30}$ These entrepreneurs, Kingdon surmised, have the ability to sense problems and advocate for a solution to solve that problem. They "attempt to 'soften up' policy communities, which tend to be inertia-bound and resistant to major changes, and larger publics, getting them used to new ideas and building acceptance for their proposals." ${ }^{31}$ Furthermore, this softening up specifically educates the public on problems that influence policy issues and initiatives. Additionally, those entrepreneurs, whether inside or outside of the government, educate the populace via the means at their disposal: speeches, congressional hearings, studies, reports, or other papers that will garner attention.

Why are entrepreneurs influential? Kingdon argued that they have some claim to a hearing, and that this claim is normally rooted in one of three things: expertise, ability to speak for others, or an authoritative decision-making position. ${ }^{32}$ Also, the entrepreneur

\footnotetext{
${ }_{29}^{28}$ Ibid., 93-94.

${ }_{30}^{29}$ Ibid., 122.

${ }_{31}$ Ibid., 122.

32 Ibid., 128.

Ibid., 180.
} 
Review of the Related Literature

is known for his or her political connections or negotiating skill. ${ }^{33}$ Finally, successful entrepreneurs are persistent. Entrepreneurs, in fact, spend a great deal of time giving talks, writing position papers, sending letters to important people, drafting bills, testifying before congressional committees and executive branch commissions, and having lunch, all with the aim of pushing their ideas in whatever way and forum might further the cause. $^{34}$

Clearly, the women who are the focal point for this dissertation possess many of the characteristics of Kingdon's entrepreneurs. But they also represent a special category of entrepreneurs, a category that does not surface in Kingdon's own research. There will be more about this uniqueness in the dissertation's final chapter.

\section{Margaret Placier, Peter Hall, Sherron McKendall, and Karen Cockrell}

Margaret Placier, Peter Hall, Sherron McKendall, and Karen Cockrell, in Policy as the Transformation of Intentions, " argued that focusing on intentions is central to understanding the policy process. "Policies convey intentions, and policy making cannot be understood without understanding actor's intentions," ${ }^{35}$ the authors wrote. Essentially, from these authors' perspective, the policymaking process becomes an arena where actors with multiple purposes, goals, and interests—-i.e. differing intentions — seek to influence and motivate other actors through various means to achieve their desired objective.

Placier and her co-authors developed their intentions-based view of policymaking in a study that was qualitative iu design and examined the development of a multicultural education policy. Key actors included school board members, administrators,

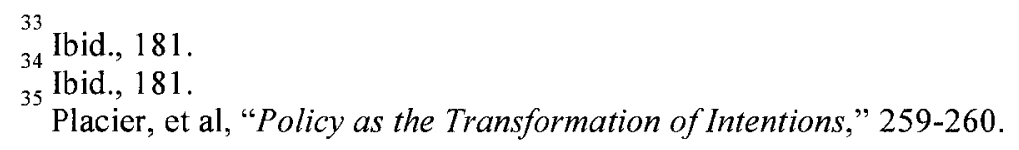




\section{Chapter Two}

participants from the community, and parents. The study revealed that a group's intentions were often ambiguous. Intentions also were tranformed, at least somewhat, by a political process that is multifaceted and a highly interactive.

The notion of intentions, of course, could be seen as a reasonable facsimile for Kingdon's concept of agendas. What the Placier, et. al. study adds is a sense of the dynamic nature of intentions/agenda. Although the women in this study essentially followed the Kingdon dictum to both stay focused and stay on message, doing this was not always easy and did not happen simply by accident. Among other things the book by Placier, et. al. sensitizes us to the fact that organizations are not individuals and that even individuals can change their minds over time. Thus, getting an organization to speak with one consistent voice is not something that happens automatically.

\section{Heifetz and Linsky}

In Ronald Heifetz's most recent book, Leadership on the Line, he, and co-author Marty Linsky provide a pragmatic approach to exercising leadership in the policymaking process. Like the other authors, Heifetz and Linsky emphasize the importance of identifying, conceptualizing, formulating, and articulating problems. Problem framing is important because the frames selected constrain and guide the search for solutions. Heifetz and Linsky's unique contribution is their emphasis on the complexity of the problem framing task and the resulting need for leadership.

In Leadership on the Line, as in Heifetz's earlier book entitled Leadership Without Easy Answers, problems are classified as either technical or adaptive. Technical problems are those for which people "have the necessary know-how and procedures" ${ }^{36}$ to

\footnotetext{
${ }^{36}$ Heifetz and Linsky, Leadership on the Line, 13.
} 
solve. Adaptive problems, on the other hand, are those that "require experiments, new discoveries, and adjustments from numerous places in the organization or community." Appeals to higher authority or authoritative expertise and a reliance on standard operating and well-established procedures do not solve adaptive problems - these are technical responses that are inappropriate for dealing with adaptive challenges.

Because adaptive problems are not solved by technical responses, Heifetz and Linsky emphasize the importance of leadership. They note, for example, that, characteristically, people look to authorities for solutions to all sorts of problems, yet they do not want authorities to disrupt their world and "confront them with disturbing questions and difficult choices." ${ }^{38}$ This is because the disruption "challenges habits, beliefs, and values." ${ }^{39}$ Yet, leadership focused on resolving adaptive problems requires this essential unpleasantness, and leaders who confront adaptive problems must expect to encounter resistance.

Heifetz and Linsky identify four dangerous responses that leaders encounter from others when the leaders confront adaptive challenge: marginalization, diversion, attacks, or seduction. Marginalization, overt or covert, subtle or obvious, removes the leader from being able to make any significant contribution to the process of the adaptive challenge. Diversion is a tactic that brings about a loss of focus on the problem at hand. Attacks refocus the group's attention on the person leading the group rather than the problem or issue being addressed. Seduction is the process by which an individual or a group loses their sense of purpose. The result of the aforementioned dynamics is the reduction of ${ }_{38}^{37}$ Ibid., 13.
Ibid., 20.
Ibid., 30. 


\section{Chapter Two}

disequilibrium, which Heifetz and Linsky believe is necessary for people to address issues and problems. The primary purpose of these responses, according to Heifetz and Linsky, is to "maintain the familiar, restore order, and protect people from the pains of adaptive work." ${ }^{40}$

To adequately respond to any or all of the tactics outlined above, a leader must engage in the simple yet also very difficult activity of gaining perspective in the midst of whirling action. The author uses the metaphor of the balcony and dance floor that Heifetz employed in his earlier book to conceptualize this activity. They contend, "Seeing the whole picture requires standing back and watching even as you take part in the action being observed." ${ }^{41}$ By gaining the balcony perspective, there is a clearer view of what is really taking place; consequently, it is less likely that the leader will "misperceive the situation and make the wrong diagnosis, leading to misguided decisions." ${ }^{42}$ However, in order for the leader to affect events, he or she must return to the dance floor to make interventions and remain engaged in the process to observe what is also happening in real time. Being involved in the balcony-dance floor process enables leaders to distinguish technical from adaptive challenges, as well as to discover where others are at in the process. This latter characteristic, of knowing where others are at, is indicative of placing a high priority on the establishment of personal relationships and valuing their perspective in the process.

In working within the political process, Heifetz and Linsky emphasize that creating, developing, and nurturing networks is crucial for addressing problems. Heifetz

$$
\begin{aligned}
& { }_{41}^{40} \text { Ibid., } 48 . \\
& { }_{42} \text { Ibid., } 52 . \\
& \text { Ibid., } 53 .
\end{aligned}
$$


Review of the Related Literature

and Linsky acknowledge, however, that in exercising leadership in the political arena there must be an ability to think politically, which involves learning to work and deal with all sorts of people, i.e., people who support one's issue, those who oppose it, and those who are uncommitted. This latter group, according to Heifetz and Linsky, are "the people you are trying to move."

Heifetz and Linsky are not naïve and do not assume that participants in the adaptive process will automatically support a proposed agenda or course of action. They acknowledge, therefore, that conflict is inevitable. What is the best way to deal with conflict? Heifetz and Linsky contend that conflict must be orchestrated and managed. When generating "adaptive change [the challenge] is to work with differences, passions, and conflict in a way that diminishes their destructive potential and constructively harnesses their energy." ${ }^{44}$ Differences, passions, and conflict will challenge deeply held convictions and experiences, which can also be sources of personal transformation. To lead people through the processes of the adaptive challenge, however, Heifetz and Linsky noted that leaders cannot become the embodiment of the conflict. The objective is to permit the generation of enough heat by those involved in the process in order for the work to be done that only they can do.

Heifetz and Linsky acknowledge that focusing attention on a problem is not without inherent difficulty. Those in positions of authority can more readily direct and redirect attention to a problem through various means at their disposal. Unfortunately, the effort to bring attention to a problem without positional authority involves risks and is a

$$
\begin{aligned}
& { }_{43}^{43} \text { Ibid., } 75 . \\
& \quad \text { Ibid., } 102 .
\end{aligned}
$$




\section{Chapter Two}

greater challenge. This may include forming alliances with those in authority positions greater than one's own because of their ability to bring attention to those issues deemed critical. Additionally, it may mean the "need to escalate [personal] behavior or rhetoric" to heighten or force attention to a specific problem. ${ }^{45}$ Engaging in such action, however, requires people to operate beyond their authority. Furthermore, as Heifetz and Linsky note, they "tread a thin line between acting out a role such that people will notice, and being so extreme that your issue (and perhaps you) will be dismissed." ${ }^{46}$

The Heifetz/Linsky view of leadership and their discussion of the adaptive nature of problems figure prominently in the story that is recounted in Chapters 4 through 8 . What this story adds is a level of specificity about exercising leadership and influencing national policy that is not generally evident in the Heifetz and Linsky book. There will be more on this in the final chapter of this dissertation.

\section{Literature About Vietnam POW and MIA Wives}

Between February 12, and April 1, 1973, 591 American POWs in North and South Vietnam were repatriated during Operation Homecoming. This term came from Secretary of Defense, Melvin Laird, who sensed that the long-awaited repatriation of the Americans captured in Southeast Asia deserved a more meaningful, more humanly engaging title than the one assigned years earlier by the Joint Chiefs of Staff: Egress Recap. $^{47}$

In the months and years that followed the prisoners' release, voluminous collections of personal accounts were produced: books, articles, interviews, papers, and

\footnotetext{
${ }_{46}^{45}$ Ibid., 157.

${ }_{47}^{46}$ Ibid., 158.

Davis, Long Road Home, 491.
} 
text of speeches. Researchers, historians, graduate students, and journalists have also contributed to an immense repository of material related to the POW experience and government policy. The Historical Office in the Office of the Secretary of Defense holds the most extensive collection of classified and unclassified archival material on the experience of American POWs in Southeast Asia.

Inconspicuous and often overlooked, however, is material written by or about the experiences of the wives and other family members of the POWs and MIAs. During the imprisonment of their husbands, many of the wives and family members wrote letters to editors, gave speeches, testified before congressional hearings, were featured in newspapers and magazines, and on television and radio. After repatriation, their letter writing campaigns and public speaking engagements on behalf of POWs and MIAs essentially ended as the women once again played the role of military wife (or, in some cases, military widows).

There were some exceptions, however. From the period immediately before repatriation of the men until today, the women have written nine books. Five books are memoirs; three of these were co-authored with husbands. The other four are fictional presentations, three of which were written under pseudonyms.

There is also a tenth account that was written neither by the wives nor by their husbands: It is a masters' thesis that examines the work and influence of one of the wives.

Two of the fictional books, Safekeeping by Jonellen Heckler and To Have and To Hold by Fern Michaels, could not be located or obtained through professional search services and therefore were not reviewed. This section of the chapter reviews the other 


\section{Chapter Two}

works alluded in the previous paragraphs. The first part of the review describes the individual works; the second part focuses on themes that cut across all of the works.

\section{A Review of the Individual Works}

Silver and Gottlieb's, Limbo. Before the end of the Vietnam War and Operation Homecoming, Joan Silver and Linda Gottlieb wrote the fictional work Limbo. The novel was crafted from interviews with POW and MIA families and a review of their personal and official correspondence. It is an account that takes the reader into the very personal and turbulent experiences of three wives who lived with the knowledge that their husbands were listed as either a POW or an MIA. This fictionalized account focuses on how the book's protagonists coped with family responsibilities, personal turmoil, governmental and military bureaucracy, civil unrest, and the growing frustration fueled by not whether the war would end and their husbands would return.

The Rutledges', In The Presence of Mine Enemies. The first collaborative effort between husband and wife came in 1973 with the publication of In The Presence of Mine Enemies by Phyllis Rutledge and Howard Rutledge. The book is divided into two parts. In the first part, Howard Rutledge wrote about his experience as a POW. Phyllis Rutledge wrote about her own experiences in the second part of the book.

There is a fundamental imbalance in the book reflective of the literature on the POW and MIA issue in general. The Rutledges' book has 111 pages; Phyllis' account, however, is only nineteen pages long.

In her nineteen pages, Phyllis Rutledge wrote about her strong religious convictions and described their sustaining power during the seven-year ordeal while her husband was imprisoned. She indicated that, like many other POW and MIA wives, she 
did not know whether she was a wife or widow for the first five years. This uncertainty contributed to mental anguish and incomprehensible stress while Phyllis attempted to rear four children and deal with two significant family tragedies.

As noted, in her section of the book, Phyllis conveys a message of faith in divine providence during arduous and trying circumstances and the resiliency of the human spirit not to succumb to fear or despondency. She did acknowledge the following, however: "I have to admit that I wasn't aware that God was working in my life during those first years of waiting." Then she quickly added: "But as I look back, it is plain to see that God was working, even then. He was working through people who cared enough to reach out and lift us up." ${ }^{48}$

The Stockdales', In Love and War. The second collaborative effort between a husband and a wife came in 1984 with the publication of In Love and War: The Story of a Family's Ordeal and Sacrifice During the Vietnam Years by Sybil Stockdale and James B. Stockdale. This is the most definitive work of the eight personal accounts written to date due to its detailed references, careful documentation, and concise chronological presentation of events. Sybil and Jim Stockdale alternate writing chapters with parallel chronological accounts of events in Vietnam (in James Stockdale's chapters) and on the home front (in Sybil Stockdale's chapters).

Sybil Stockdale's chapters reveal that initially, like most of the women, she trusted the wisdom and guidance of the Department of Defense, Department of State, and the President of the United States. However, Mrs. Stockdale indicates that the wisdom of the trust approach soon came into question, especially after government and military

${ }^{48}$ Rutledge and Rutledge, In the Presence, 115. 


\section{Chapter Two}

officials who were unable to provide consistent information and, in fact, often provided contradictory responses. At that point, Mrs. Stockdale indicates that she and some of the other wives immersed themselves in a self-education process about the war, Vietnam, and the Geneva Convention provisions related to the Treatment of Prisoners of War. Mrs. Stockdale indicates in her chapters that the knowledge she acquired emboldened her to approach and confront leaders at the highest levels within the government and military. Her sustaining motivation throughout the many years of her husband's captivity, however, came from an internal compulsion to find something that she could do to help her husband.

In the chapters she authored, Mrs. Stockdale indicates that a primary irritation for her and others the government's Keep Quiet policy. (The terminology is hers and the other wives with whom she interacted; officially, the Department of State policy was characterized as "Quiet Diplomacy.") The Department of State's, Quiet Diplomacy/Keep Quiet policy, meant that the United States government would not criticize North Vietnam for violations of the Geneva Convention provisions about the humane treatment of prisoners of war, as well as, referring to a strategy of using diplomatic pressure on North Vietnam to handle and/or address POW and MIA matters. For family members, this policy translated into directives to refrain from publicly discussing the status of their husbands or, in the case of parents, their sons. Sybil's frustration and anger with this policy led to activist activity that resulted in the eventual formation of the National League of Families of American Prisoners and Missing in Southeast Asia. This organization designed itself to become a potent force within the Department of Defense, Department of State, Congress, presidential administrations, and with the North 
Vietnamese delegation in Paris. Simultaneously, the members of the organization were highly influential in acquiring the support of the American public and the private business sector once they went public with the truth about the treatment and violations of the Geneva Convention. In both arenas, Sybil was able to utilize her influence, the influence of other wives, and the power of the League to force the POW issue into the forefront of American policy and the American consciousness.

In some respects, the findings that follow cover much of the same ground that Sybil Stockdale covers in the chapters she wrote for In Love and War. This is hardly surprising since Sybil Stockdale was a key informant—and, arguably, the key informant for the study being presented here.

This dissertation study, however, also tells the stories of other women who aligned themselves with Sybil and her work, and it tells even Sybil's now-triangulated story in considerably more detail than the story she, herself, told in her chapters in the book she wrote with her husband. More importantly, the dissertation study also examined events from the government perspective through the analysis of Presidential papers and interviews with key government officials of the era. This latter component is especially important since, until the information that was uncovered in the review of documents and interviews with government officials was shared with Sybil and her compatriots, they doubted the influence they had had. This dissertation documents this influence and makes it part of the historical record.

Keenan's, Every Effort. The first single-authored historical account was written in 1986 by Barbara Mullen Keenan and titled Every Effort: One Woman's Courageous Search For Her Missing Husband-A True Story. Keenan's story begins much like the 


\section{Chapter Two}

others: recalling marital happiness, family togetherness, family trips to exotic places, and an unabashed pride in her husband's profession and commitment to serve his country. She also tells of her life before her marriage. During that period, she championed American ideals by venturing to Bangkok, Thailand, to work for the Voice of America. Patriotism, the American Dream, and stopping the spread of Communism were rallying cries that she, personally, had responded to much as military men like her Marine husband had done when they marched off to battle.

Much like Sybil Stockdale's part of In Love and War, Keenan recounted in Every Effort her early years as a dutiful Marine wife obeying the dictates of the government policy for wives of POWs and MIAs. She also chronicled her growing anger at the futile attempts by the Department of State, Department of Defense, and United States Marine Corps to locate her husband. Like many other wives, she immersed herself in the activities of the National League that Sybil Stockdale and her compatriots had founded, but she indicated that she soon was at odds with the League's direction and refusal to question national policy regarding the war in Vietnam.

Her personal commitment to challenge the government's policies related to the war-and not just focus on the treatment of the POWs-took her into the halls of Congress to meet with and support the Vietnam policy measures of Senators Ted Kennedy (D-MA), George McGovern (D-SD) and Congressmen Pete McCloskey (R-CA) and Robert Leggett (D-CA). Even though she remained out of sync with the official stance of the National League of Families, Keenan remained a member to influence the direction of the organization from within. 
Review of the Related Literature

Eventually, she wrote that she and others parted with the League because of its unwillingness to criticize President Nixon's policies and her belief that the League was solidly pro-Nixon administration. This split resulted in the formation of "The Families for Immediate Release." She did not cease criticizing the National League of Families, however, and, in fact, in her book, she reveals her cynicism and utter contempt for what she believed the League had evolved into: a pawn and propaganda tool of the Nixon administration. In her book, Keenan also wrote, with surprising candor, about the divisions between POW and MIA wives within the National League and The Families for Immediate Release, which were aired privately, publicly, and in congressional hearing rooms.

Keenan, whose husband was shot down in Laos and listed as an MIA, detailed how she anxiously awaited for the official release list to be presented in January 1973. Much to her horror, dismay, and disbelief she realized that nothing in the Paris Peace Accords addressed the POWs held in Laos. In spite of her efforts to appeal to the President, the Department of State, Department of Defense, and United States Marine Corps-nothing happened because too many Americans thought the war was over.

Keenan's Every Effort is an important compendium text for this dissertation because it focuses on people and activities that this dissertation study did not cover. Until someone writes a more systematic history of the anti-Vietnam group within the "community" of POW/MIA wives and family members and the organization this group formed after breaking with the National League, Keenan's highly personal account will continue to be a valuable resource. It certainly provides an alternative perspective on the events described in the findings chapters of this dissertation. 


\section{Chapter Two}

Taylor's, Honorbound. Laura Taylor book, Honorbound, is another fictionalized account of the experiences of a wife of a POW. The book also tells about the character's husband. The book's structure, in fact, is highly reminiscent of the Stockdales' nonfiction book, In Love and War. Here, too, alternating chapters depict the experiences of a POW in North Vietnam - in this case named Matt—and his wife, Eden, back home. Of course, despite the structural similarities between the two books, there is a highly significant difference: Taylor's Eden and Matt are fictional characters, though, fictional characters that, undoubtedly, bear more than a family resemblance to Taylor and her husband.

Taylor's novel conveys a simple but meaningful story of love, tragedy, hardship, personal growth, and love renewed. Interestingly, Taylor does not develop her female protagonist, Eden, as someone who courageously adjusts to the news of a missing husband. Rather, the story Taylor tells is of a young woman experiencing ceaseless inner turmoil who must cope with the death of her infant son; subsequent depression and alcoholism; emotional and physical loneliness; and a sexual interlude. All the while, she does not know if she was a wife or a widow.

In time, Eden, matures beyond the level of her peers and develops an inner intuitive spirit. The story is not a moralistic judgment on a woman's behavior; nor is it a psychological profile of a young woman caught in an emotional struggle to cope and find meaning in life. The value in the book, regardless of it being a novel, is that it focused on the emotional toll the POW/MIA wife experience took on the women who were forced into that role. This aspect is alluded to in Chapter 8 of this dissertation; the dissertation, however, focuses on other things. Thus, Taylor's fiction can be viewed as yet another 
important supplement to the work presented here. It tells in fictionalized form, the emotional piece of the story that, arguably, can best be told in novel form.

McDaniel's, After the Hero's Welcome. In After the Hero's Welcome: A POW Wife's Story of the Battle Against a New Enemy, Dorothy McDaniel not only traced her experiences from 1967 to 1973 when her husband was classified as Missing in Action. She also described what happened after Operation Homecoming in 1973 when her husband did not come home and she had to confront the possibility that American military personnel — including her husband - were left behind in Vietnam and Laos.

Like so many other wives, McDaniel experienced the harsh reality of the continuous lack of information from the Department of State and Department of Defense. What she did know came from the official Navy telegram, which not only informed her of her husband being shot down but also indicated that to ensure his safety and well being, she could only tell immediate family members about his disappearance. After a few months, other messages arrived that contained admonitions and assurances from the White House and the Department of State about official efforts on behalf of the men. Soon these messages began to have a familiar ring: They talked about secret negotiations, maintaining trust in the government, and contained the standard punch line: "We're doing everything we can."

Like Sybil Stockdale, McDaniel refused to be quiet and began making trips to Washington DC for answers. She sought out and made appointments with both elected and appointed governmental officials. These meetings led McDaniel to conclude that the

${ }^{49}$ McDaniel, After the Hero's Welcome, 52. 


\section{Chapter Two}

status and treatment of the men was not a preeminent concern of people in governmental positions.

Like most of the other wives who turned into activists, McDaniel's passion and commitment were fueled by a desire to do something for her husband. This commitment took her back to Washington DC again and again to confront those in positions of authority who had the power to make policy. After joining the National League, she along with other wives in the Virginia Beach area where she lived, became committed to informing the public - through whatever means - about the plight of the prisoners. By doing this, McDaniel and the other Virginia Beach wives believed they would put pressure on the American government to do something that would embarrass Hanoi into abiding by the Geneva Convention.

In time, the National League, POW and MIA families, and the prisoners themselves were front-page news. McDaniel recalled the development of the National League from a loosely organized group into one that was highly organized with coordinators in every state. Between 1971 and 1972, McDaniel was aware that the relentless pace of keeping the prisoners front-page news, maintaining the pressure on Washington, and focusing public attention on Hanoi had become exasperating. Candidly, she writes briefly about the 1972 meeting of the National League, which she considered a melee of accusations fueled by years of frustration.

Like many of the other works discussed here, McDaniel's book is an important compendium to this dissertation study. Among other things, it focused on activities on the East coast, while this dissertation could be thought of as West Coast centric, even though six of the thirteen wives were from the Midwest or east coast. In short, the McDaniel 
book reminds us that, although the idea of National League was "hatched" by the women who gathered around Sybil Stockdale's table in Coronado, California, there was other activity happening elsewhere. These other activities are discussed all-too-briefly in this dissertation. The work of the Virginia Beach chapter that McDaniel describes is, most certainly, underplayed due to space and focus considerations here.

The McDaniel book is also a valuable compendium to what is being presented here for one other reasons: Like Keenan's Every Effort, this book reminds us that some women's ordeals did not end with Operation Homecoming. Operation Homecoming brought some semblance of closure for ten of the thirteen women interviewed for this study. The McDaniel book reminds us that this was not the case with everyone.

The Purcells', Love and Duty._The last book published by a POW wife was a book that Anne Purcell published with her husband, Ben Purcell, in 1992: Love and Duty. The Purcell's appear to have written their book to inspire others, to demonstrate courage and commitment to each other in the face of extreme adversity and to acknowledge their faith in Providence. The Purcell's compelling story also demonstrates that, even nearly twenty years after Operation Homecoming, the experience of being a POW wife remained highly significant.

Ann Purcell was a woman with five children when confronted with the first official message of her husband's MIA status. Like other MIA wives, this news meant dealing with the haunting question: Am I a wife, or am I a widow? Twenty-two months after her husband's disappearance, Purcell and her children joined 147 other family members of POWs and MIAs for a trip to Paris to meet the North Vietnamese delegation at the Paris Peace Talks. For Purcell, this trip (and her involvement with the National 


\section{Chapter Two}

League) strengthened her resolve to make public the inhumane actions of the North Vietnamese. Her goal was to turn public opinion against the North Vietnamese and force American support for the POWs by having the government embrace a policy that would ensure their humane treatment.

Purcell recounted the activities of the League in summary fashion but detailed certain events in order to acknowledge the significant influence they had made on the public and political arena. Unlike the authors of other historical memoirs, her involvement was limited to her state of Georgia, though she did travel to Washington DC for National League meetings. Her arena, however, was the Columbus, Georgia area where she dutifully carried out the request of the League to make the plight of the prisoners known. Thus, the Purcell book provides a case in point of how the League's use of regional coordinators played out at the local level. In this respect, at least, it, too, can be considered a compliment to the findings that are being reported in this dissertation.

Garrett's, The Power of One. In addition to the works written by the wives themselves, there is also one master's thesis that focuses on one of the POW/MIA wives: David Garrett's The Power of One: Bonnie Singleton and American Prisoners of War in Vietnam. In his thesis, Garrett describes the events that lead up to Bonnie Singleton's activities with other wives and mothers on behalf of the prisoners. Bonnie Singleton's husband, Jerry, was officially designated as MIA for five years before Bonnie learned that he was, in fact, a POW. Like the other wives, Singleton wrote that she knew about the government's policy requiring wives to "keep quiet" about their husbands' situation.

Garrett's thesis traces Singleton's transformation from an obedient military wife to an activist. The transformation, according to Garrett, began when the wife of the 
Review of the Related Literature

Commanding Officer of the USS PUEBLO (Navy ship captured by North Korea in 1968) spoke out against the government and used news conferences to discuss the plight of the men in captivity in North Korea. This led Singleton, along with other wives in the DallasFort Worth area, to organize in order to gain information from the government about their husbands and, possibly, provide aid to them.

Garrett porfrays Singleton as a tireless public activist who spearheads the POW and MIA issue before the American public, politicians, and North Vietnamese diplomats in Hanoi and Paris. Though other wives are mentioned in the thesis, they appear in supporting roles and their activities are framed as support for Singleton's goals and objectives.

Garrett attempted, without thorough documentation, to connect Singleton's activities with governmental policy shifts. Among other things, he detailed Singleton's meeting and subsequent follow-up conversations with Tricia Nixon (daughter of President Richard Nixon) during a campaign stop she made with her father in Dallas, Texas. Their conversation, he wrote, resulted in Tricia Nixon telling her father about Bonnie and her story about being the wife of a POW. Garrett inferred that this directly and single-handedly led to President Nixon releasing a statement about how he would handle the POW issue as President, though the evidence to support this claim is circumstantial, at best.

Although Garrett's work focused on one person and, almost certainly, overstated the impact of a single individual, his thesis does provide a valuable supplement to this dissertation. Bonnie Singleton was also one of the wives interviewed in this study, and her activities in the Dallas area are alluded in this dissertation. There was not space, 


\section{Chapter Two}

however, to provide the sort of detail about Singleton's work in Dallas that can be found in Garrett's work. On the other hand, this dissertation puts Singleton's considerable achievements into a larger context and, consequently, tells a story of collective leadership rather than reinforcing a great person or lone ranger view of the leadership process.

\section{Cross-Cutting Themes in the Literature About POW and MIA Wives}

The previous section briefly examined each of the individual works about the POW/MIA wives in isolation. Here the focus is on themes that cut across all of the works reviewed.

The literature that was reviewed as part of this dissertation study is, in fact, amazingly consistent. Presumably some of this consistency is attributable to the fact that many of the authors interacted with each other and, consequently, constructed social reality in similar ways. It is also possible — and even likely - that those who wrote their books later rather than sooner had read and were influenced by earlier publications. For whatever reason(s), all the publications - even the fictional ones and ones written by those with somewhat different political agendas_emphasize the same sort of events: the official notification by military personnel; receiving assurances from the government about their husbands' well-being; being informed about the government's Keep Quiet policy: and a growing discontent and frustration with the government.

\section{Notification}

All the authors began their stories by recalling, in vivid detail, the experience of being notified that their husbands had been shot down and were, consequently, classified as either POWs or MIAs. The richness of each author's narrative revealed how this episode has been permanently etched into the wives' consciousness. Emotional trauma, 
disbelief, mental anguish, and confusion were common experiences. In each account, the process of notification was depicted as a formal and highly ritualized event with two or more uniformed officers, one usually being a chaplain, arriving in a black car to deliver the official message from the Department of Defense or a branch of the military. The opening verbiage was somewhat routine and included expressions of regret.

Not surprisingly, the news always came as a shock. The authors described a multitude of psychological and physiological reactions: feeling numb, walking about in a daze, attempting to find some direction, burying oneself with efforts to make plans on how to proceed, feeling concern for the children (if the couple had children), and feeling grave concern and interest in the status and well being of their spouse.

\section{Government Assurances}

Once the wives had been officially notified, they were given assurances that the government was taking appropriate action on behalf of their husbands. The actions specified differed somewhat depending on the context. Wives were assured either that the military was attempting to locate their husbands, that search and rescue efforts would be undertaken, or that there was an effort to determine their husbands' status: killed in action (KIA), MIA, or POW. Frequently, government officials assured the women that everything possible was being done to ensure the men were being well treated-and even that they had no reason to doubt that the North Vietnamese would treat their husbands humanely. In each of the accounts, however, the wives, in time, understood they had many reasons to doubt the government's claims about humane treatment. 
Chapter Two

Keep Quiet

Every book referred to the wives requirement to comply with established governmental guidelines. According to Keenan, these guidelines had five elements:

- Refrain from furnishing any persons outside of your immediate family with any background data regarding your husband's personal history and military service.

- Do not speak with the media.

- Refrain from providing any information that could be used to adversely affect your husband.

- The Department of Defense, governmental or private organizations will not be of help to assist with additional information.

- Do not write to communist leaders or heads of state.

Collectively, the books reviewed suggest that, often, these guidelines were articulated during the official notification. On other occasions, the guidelines were contained in a follow-up telegram, or included in a letter from the Department of Defense or the relevant branch of the military. The guidelines normally were accompanied by a warning: Any violation might result in harm to a wife's husband.

For McDaniel, Stockdale, Keenan, and Singleton, at least, the Keep Quiet policy quickly was perceived as a ruse to keep the pressure off politicians and disguise the fact that they were not really doing much to help. All the wives, in both the fictionalized and the nonfiction accounts, eventually came to believe that the politicians and military officials possessed information that would not be disseminated to wives and that they

${ }^{\text {so }}$ Keenan, Every Effort, 18. 
were attempting to cover up the fact that the government officials were pursuing a flawed policy.

In a visit to Washington DC in June 1967, Stockdale wrote that she requested from Ambassador Harriman that a representative from the Department of State travel to San Diego to speak with the wives about the government's efforts to ensure humane treatment for the men. This request reflected her conviction that the "government should be doing something besides keeping quiet."

\section{Discontentment and Frustration}

In addition to discussing the government's directive not to talk publicly and its perfunctory assurances of the men's well-being, the women wove into their narrative accounts of the growing discontent and frustration with their lack of information regarding their husbands. Oftentimes the information that they did receive was inconsistent with previous disclosures. Stockdale, for instance, said that she was "completely disappointed by the incompetence of the system." ${ }^{52}$ Keenan wrote that the "words that trickled in from Southeast Asia and Washington confused us."

Six weeks after learning that her husband had been shot down, McDaniel still had not heard or received any additional information from the Department of State, Department of Defense, the United States Navy, or her husband's squadron. "Six weeks of screaming silence" she wrote. ${ }^{54}$ Purcell was somewhat more fortunate. She indicated that she received her first piece of official information from her husband's commanding

\footnotetext{
${ }_{52}^{51}$ Stockdale and Stockdale, In Love and War, 216.

${ }_{53}$ Ibid., 121.

${ }_{54}^{53}$ Keenan, Every Effort, 35.

McDaniel, After the Hero's Welcome, 37.
} 
Chapter Two

officer a month after she had been notified. She indicated, however, that she "felt he should have written sooner."

\section{Self-Education}

Three women, Stockdale, Keenan, and McDaniel, made numerous references to their obsession with obtaining as much knowledge and information they could about Vietnam, North Vietnam, the war, the Washington DC bureaucracy and power brokers, and the Geneva Convention. Their writings indicated that they used a wide array of resources: books, newspapers, magazines, television, government documents, conversation with political and military officials, and through written inquires.

In the fall of 1965, Sybil Stockdale requested a reading list from the Department of State. She received it six months later.

\section{Motivation}

Half of the wives claimed that their motivation for being persistent-even relentless - with the Department of State, Department of Defense, Congress, and the Johnson and Nixon administrations - came from a commitment to their husbands. "Somehow, some way, I had to find something I could do to help Jim," wrote Stockdale. ${ }^{56}$ McDaniel wrote of "choos[ing] a course of action, not for reasons of expedience or convenience, but because it is the right thing to do." ${ }^{57}$ Even though she wrote very little of her experience, Rutledge nonetheless, wrote of her efforts "to keep

\footnotetext{
${ }_{56}^{55}$ Purcell and Purcell, Love and Duty, 72.

${ }_{57}^{56}$ Stockdale and Stockdale, In Love and War, 231.

McDaniel, After the Hero's Welcome, 201.
} 
our men remembered." ${ }^{58}$ Keenan recalled that, on sleepless nights, she would plot searches to uncover information about her husband.

McDaniel noted that, in 1970, the Virginia Press Women awarded the "Newsmakers of the Year" to the POW wives. The citation read in part: "Armed with love, they are fighting the battle for their husbands."

\section{Networking}

As the number of POWs and MIAs increased, the number of wives and family members increased, especially in certain geographical locations where there were major military installations. Since deployments to Vietnam were in the form of squadrons or similar sorts of units, wives were able to ascertain, through various means, the names of other wives who had been notified of their husbands being listed as a POW or MIA. Unfortunately, the Keep Quiet policy continued to influence a number of wives. For instance, when attempting to organize a wives get-together on October 7, 1966, Stockdale discovered a number of women who were fearful to talk to her on the phone because it violated one of the guidelines. In spite of the policy, there was a growing interest among most of the wives to get-together and talk about their situation, find out who had been told what and by whom, share other sorts of information, and provide moral support.

Initially a network of wives sprung up in San Diego, California, through the efforts of Stockdale; in Virginia Beach, Virginia, through the efforts of Louise Mulligan; and in Dallas, Texas, through the efforts of Bonnie Singleton. As the networking became more organized within geographical locations, Stockdale led the effort from her home in

\footnotetext{
${ }_{59}^{58}$ Rutledge and Rutledge, In the Presence, 120.

McDaniel, After the Hero's Welcome, 201.
} 


\section{Chapter Two}

Coronado, California, to disseminate information, via telephone and form letters, to other wives or family members of POWs or MIAs. The result was an expanding network of wives, mothers or fathers who, at least in one respect, had a shared identity: a loved one was either missing in action or a prisoner of war. Keenan echoed a common sentiment among the wives about discovering and talking with others in the same situation. "You can't image how alone I've felt," she told POW wife Louise Mulligan, "No one else, no one can understand what it's been like except another woman who's been through it." ${ }^{60}$ As these enclaves were growing and linking up across the nation, McDaniel noted that the wives who attended the meetings were "slowly becoming an activist group." Yet, she added, "None of us were brave enough-yet—to defy the keep-silent rule." Contacting Elected and Appointed Officials

The accounts that were reviewed indicated that, in time, both individually and in small groups, the wives began making contact with officials in Congress, the Department of State, and the Department of Defense who they believed could provide answers to their questions. Three women, Stockdale, Keenan, and McDaniel, relatively quickly began contacting officials in the government and the military. During her trips to Washington DC, McDaniel felt that many congressmen seemed uninformed and that she, as well as many of the wives, ended up educating them not only on the POW and MIA issue, but also about the war itself. Stockdale's connection to Washington DC was initially accomplished by phone calls, letters, and telegrams - and then personal visits.

\footnotetext{
${ }_{61}^{60}$ Keenan, Every Effort, 43.

${ }_{62} \mathrm{McDaniel}$, After the Hero's Welcome, 53. Ibid., 53.
} 
All three women, however, knew that nothing took the place of a personal visit to people in positions of authority - especially those in Washington DC.

\section{Going Public}

Through the early part of 1968 , Stockdale continued to maintain contact with various government and military officials. Two men, Ambassador Harriman and Admiral Moorer, continually expressed their belief that the prisoners were being treated humanely, though Sybil had grave doubts about Harriman and Moorer's belief. While making the rounds in Washington, Sybil Stockdale asked Commander Boroughs, an officer in Naval Intelligence division and one of her primary contacts in the Navy, about his thoughts on her going to the press. By the end of the summer of 1968 , she had convinced herself and Commander Boroughs that it was time to go public with her story.

The literature indicated that other wives followed Stockdale's lead. McDaniel recalled her own response: "With no holds barred, I jumped into the public arena that Sybil [Stockdale] and Louise [Mulligan] and some of the other wives and mothers had already entered." ${ }^{63}$ The literature revealed that the wives' public statements focused on three more-or-less related tasks: informing the public about the plight of the men, putting pressure on the United States Government to address the POW and MIA issue, and compelling the government to demand that North Vietnam abide by the Geneva Convention Relative to the Treatment of Prisoners of War.

\section{Establishing an Organization}

Stockdale's chapters in In Love and War describe the formation of, first, a regional and, then, a national organization. There are two significant dates related to the

\footnotetext{
${ }^{63} \mathrm{McDaniel}$, After the Hero's Welcome, 55.
} 
Chapter Two

formation of these two organizations that Stockdale's writings addressed. First, on October 7, 1967, the League of Wives was formed in San Diego, California; second, the decision to form a national organization was made on June 20,1969 , and was announced to the 350 families on the mailing list in that month's newsletter.

In June 1970 , an ad hoc committee met to discuss and then vote on officially incorporating as a non-profit organization in Washington DC. This same committee decided that membership in the incorporated version of the National League would be limited to family members of POWs or MIAs.

The formal event signaling the incorporation of the National League occurred on June 30, 1970, at the League's offices at 1 Constitution Avenue, Washington DC. Before officially incorporating, the League followed used largely informal networking to hold its organization together. The Stockdale account indicates that networking continued to be an essential component to the more formal-and legally recognized-organization that was founded in June of 1970 . The difference was more one of degree than one of kind: traditional networking and lobbying activities now occurred on a much grander scale and had a far more reaching impact.

All the reviewed literature discussed the wives' knowledge of and involvement with the League. For some wives, the League became a centerpiece of their lives while, for others, the organization was more a peripheral part of their day-to-day lives. Of course, as noted previously, one wife, Keenan, eventually left the National League and formed her own organization that was critical of the administration's war effort. 
Publicizing the POW/MIA Issue on a National Scale

The literature revealed that the League utilized a broad range of strategies to publicize its concerns. The strategies included: massive letter writing campaigns to politicians and major newspaper editors; newspaper advertisements; petition drives; television and radio interviews; public speaking; and adopting the bracelet developed by Voices In Vital America (VIVA).

The individual accounts provided specifics about the strategies employed. In Virginia Beach, Virginia, for example, McDaniel worked with the Junior Chamber of Commerce to get the national Jaycees organization to initiate a POW and MIA awareness campaign. The result was the creation of a nationwide campaign that centered on the theme, The World is Watching. McDaniel's account also indicates that her son started the Don't Let Them Be Forgotten campaign at his school in Virginia Beach.

The master's thesis about Bonnie Singleton described how she initiated an organization with a publicity program to maintain a high profile awareness campaign: Youth Cares and Dallas Cares. The purpose was to campaign for the prisoners' cause and to enlist non-family members in the effort.

Even those who were not part of the national organizations insider group indicated that they got on the National League's publicity bandwagon. Purcell, for instance, wrote that, though she did not involve herself in the internal politics of the League, she did support its goals to educate the world and keep the POWs and MIAs foremost in the minds of Americans.

Finally, Sybil Stockdale made clear in the book she wrote with her husband that she understood the need to keep the plight of the POWs and the truth about the North 


\section{Chapter Two}

Vietnamese violations of the Geneva Convention in the public's consciousness, whether through local groups, the national organization, public and private citizens, or a variety or civic or corporate organizations. She also indicates that during a visit to the New York Times, she learned that the media had become the National League's strongest ally. She indicates that she understood that this relationship had to be maintained.

\section{Disagreement Within the League}

The accounts of Stockdale, Keenan, McDaniel, and Singleton all describe a major schism within the League. Keenan, especially candid about this matter, devoted considerable attention to describe the devisive issues. Stockdale, by contrast, wrote very little about the League's disagreements. She did write, however, that she did not believe there was any harm in having a "radical fringe group as part of [the] organization." ${ }^{64}$

McDaniel recalled that the May 1972 meeting of the National League was a melee "with families shouting at one another, venting their frustration on people who were suffering just as they were." ${ }^{65}$ She recalled that derogatory accusations were tossed back and forth among members and that wives who supported President Nixon were accused of being caught up in the "Rose Garden scene. ${ }^{66}$ Even though McDaniel was not an active participant in the melee, she still felt that the bureaucrats behind the scenes were saying, "Keep them happy at any cost." ${ }^{67}$ Keenan, wrote of that time, she "wanted to be concerned again with ordinary things. . . I feel all-out sad." ${ }^{68}$

\footnotetext{
${ }_{65}^{64}$ Stockdale and Stockdale, In Love and War, 390.

${ }_{66}^{65} \mathrm{McDaniel}$, After the Hero's Welcome, 78.

${ }_{67}^{6}$ Ibid., 78.

${ }_{68}$ Ibid., 79.

Keenan, Every Effort, 281 and 300.
} 


\section{Years of Work Take a Toll: Exhaustion}

The depressing sentiments and numb feelings that Keenan expressed quite eloquently in the last sentence above are reflective of other women. In five of the nine accounts, there is some mention of the emotional and psychological effects of events. The women had endured significant and sustained emotional stress that was exacerbated by constant uncertainty over their husband's well-being or status. Coupled with this was the plethora of obstacles they had to work relentlessly to overcome.

\section{Conclusion}

This review of the literature has set the stage for the presentation of findings from this dissertation study by focusing on two quite different bodies of literature. One body contains largely theoretical discussions of citizen participation; the other body of literature contains accounts, some of them fictionalized, about citizens' attempts to participate in the policymaking process at the National Level.

Both bodies of literature set the stage for what is to follow, but both also has inadequacies. The theoretical discussions about citizen participation provide a broad outline of what might happen when groups of citizens make an attempt to get involved in the policy-making process, but this body of literature is short on details. The second body of literature is rich in details but, because it contains autobiographical and even fictionalize accounts of experience, does not provide a more distanced, theoretical perspective. The second body of literature also makes no attempt to actually document the impact of the tactics the women employed on government officials and "connect the dots" between the women's actions and policy changes. 


\section{Chapter Two}

The findings that followed, to some extent at least, address the limitations of both bodies of literature that were reviewed in this chapter. Before the findings are presented, however, the methods that were employed to generate them must be discussed. This is the topic of the next chapter. 
Chapter Three: Methodology

\section{Research Design and Methodology: An Overview}

The purpose of this study was to examine how a group of military wives during the Vietnam War became significant players in the national and international policy process after their husbands were listed as POWs or declared MIA. Through life history interviews, I collected data from the wives about their experiences as POW or MIA wives and their subsequent public activism within the policymaking arena. These data were triangulated through document analysis. Documents that were analyzed included letters kept by the wives, organizational newsletters, and newspaper accounts of the women's activities and of the organization they founded.

Additional primary source material came from individuals associated with the executive branch and the Department of Defense. Some of these data were gathered through interviews and/or correspondence with former high-ranking government officials. Presidential papers accessed through the National Archives and Records Administration and the Freedom of Information Act also were used as data in reconstructing the government's response to the wives and their organization and, more specifically, in tracing the impact of the wives' actions on public policy.

Thus, the research contained in this dissertation presents the stories of thirteen wives of POW or MIA in North Vietnam 1965-1973, ${ }^{69}$ the perspectives of five high ranking officials during the Presidential administration of Richard M. Nixon, and

${ }^{69}$ One wife decided, several months after the interview and her review of the transcript, to withdrawal from the study. Since her material was rich in detail and depth, I requested her permission to use a pseudonym along with omitting her geographical location. She declined and I removed her material from the study. 
Chapter Three

information gleaned from documents and records taken from governmental or personal archival material. Due to the historical nature of events, participants permitted the use of their actual names.

My intent with every interview I conducted was to discover how participants would "impose order on the flow of experience to make sense of events and actions in their lives" ${ }^{70}$ and "give meaning to their experience of temporality and personal actions." ${ }^{71}$ The analysis of the data, which will be discussed below, was guided by Riessman's admonition: "The challenge is to find ways of working with the texts so the original narrator is not effaced, so she does not loose control over her words." ${ }^{72} \mathrm{My}$ responsibility, therefore, was not to obscure the voices of the wives of Prisoners of War or Missing in Action with my own theorizing but to represent the women's thoughts and feelings as they might themselves represent them if they were writing this dissertation.

Fulfilling this responsibility was not easy because what the wives narratives continually emphasized was the continuous movement of ideas, events, actions, challenges, frustrations, and accomplishments. Their work was clearly improvisational and often characterized by serendipity. Furthermore, the women tended to eschew the use of the narrative historian's standard organizational device, chronology, and tended to tell their stories thematically. The thematic organization helped highlight the ad hoc and improvisational nature of the work, but it also could be confusing, given that the events they were describing did, indeed, unfold over time.

\footnotetext{
${ }_{71}^{70}$ Riessman, Narrative Analysis, 2.

${ }_{72}$ Polkinghorne, Narrative Knowing, 11.

Riessman, Narrative Analysis, 34.
} 
In this retelling and amalgamation of the stories that were told to me, and the stories implicit in various documents that were reviewed, I have not totally abandoned the use of chronology to bring some semblance of order to complex events. Nevertheless, I have leavened the chronological account with a focus on many of the themes that the women used to structure their reconstructions of their highly personal individual histories. Thus, the meta-story that is told here in Chapters 4 through 8 will frequently cover the same ground multiple times, albeit from varying perspectives. This is especially the case when the focus shifts, in Chapter 7, to the government's response to the women's attempts to exercise leadership and influence public policy on the POW and MIA issue.

Of course, before this history could be written, many other methodological decisions had to be made and enacted. The remainder of this chapter describes these decisions and the research procedures associated with them.

Specific Research Decisions and Procedures

\section{Selection of Research Participants}

The participants in this study were either the wives of Vietnam-era POWs or MIAs or high-ranking government officials who dealt with the POW and MIA issue during the Vietnam era. Thirteen wives were interviewed; they were selected because they had been actively involved with other POW and MIA wives prior to the development of a national organization but had also participated in the development of the national organization. Demographically, seven were from west coast and six were from the Midwest or east coast. More specifically, interviewees met the following criteria: 
Chapter Three

- The wife's husband became a POW or was listed as MIA during the Vietnam War prior to May, 19, 1969;

- The wife had a substantial involvement with other POW and MIA wives prior to the formation of the National League of Families on June 20, 1969;

- The wife was actively involved with the League of Wives and/or the National League of Families.

In addition, an attempt was made to enlist a minimum of six elected or appointed officials, as well as a private citizen who had been worked with the POW and MIA issue and with the wives. Two of these individuals declined to participate in the study after a lengthy negotiation process with members of their staffs, though, in at least one case, the Presidential papers that were reviewed provided considerable evidence of the stance he took and the role he played.

The following criteria were used in selecting governmental officials:

- they were knowledgeable about the government's policy concerning the POWs and MIAs

- they had had direct experience with the POW and MIA wives, as well as one or both of the organizations the wives had formed, i.e., the League of Wives or the National League of Families

A list of potential participants was drawn from the literature review. James and Sybil Stockdale's book, In Love and War, was especially helpful in generating a list of potential interviewees. As had happened in some research that I had conducted as a kind of trial run for this dissertation, initial interview participants readily recommended other wives and governmental officials for participation in the research project. This type of 
sampling, known as snowball sampling, is the most common form of purposeful sampling in qualitative research. ${ }^{73}$

In the end, more interviewees who met the criteria listed above were suggested than could be interviewed. Those who I judged could provide the greatest amount of information about the women's story - and, in the case of government officials, the government's reaction to the Leagues' agenda—-were selected to be interviewees for this study.

Selection of Documents and Records to be Analyzed

Primary source documents and records from wives, officials, White House Files, and material from Congressional hearings and the Congressional Record were reviewed as part of the data gathering effort. Lincoln and Guba distinguish between two types of materials that can be analyzed based on whether or not they were written for a public purpose. They characterize materials prepared for a public purpose as records and materials generated for private use as documents. ${ }^{74}$ Both types of materials were used in this study. The women generously opened their personal files to me; often these files contained a treasure trove of documents. The National Archives contained both records and documents from the Nixon Administration.

The review of National Archives documents and records was intentionally openended. The selection of material began by determining what particular files contained POW and MIA material related to the Vietnam War and, more specifically, President Nixon. In 2001, I contacted the National Archives with a specific request to review POW

\footnotetext{
${ }_{74}^{73}$ Merriam, Qualitative Research, 63.

Hodder, "The interpretation of documents and material culture," 703.
} 


\section{Chapter Three}

and MIA files from 1968 to 1973 . The archivist assigned to materials catalogued under "Nixon Presidential Materials Staff" sent me a number of informational papers about National Archives procedures that needed to be reviewed before a researcher began to utilize materials in the National Archives. The papers I was provided with included:

- Reference Information Paper on POW AND MIA Records

- Documents Relating to POW AND MIA Matters Among the Nixon White House Files of the National Security Council

- White House Central Files, Subject Categories, ND 18-3 Prisoners, National Security - Defense

- White House Communications Agency Sound Recordings

These papers were invaluable in mapping a strategy to search specific files and boxes of records and documents.

A cursory reading of the listed references belies the magnitude of material available for review, which numbers in tens-of-thousands of pages, not to mention the hundreds of subcategories within each major file. Based on a thorough reading of the papers sent to me - and a subsequent meeting with the Nixon archivist-I narrowed my focus to materials contained in the following files: White House Central Files-National Security Defense (Prisoners) (ND 18-3); Nixon Presidential Materials Staff; White House Special Files-Staff Members and Office Files; White House Special Files-Alexander P. Butterfield; President's Office Files-Memoranda for the President; President's Office Files-President's Handwriting; and National Security Council Files-Henry A. Kissinger Office Files and POW AND MIA Files Collection. These materials were read and detailed notes were taken. 
Interview Procedures

The primary data collection method used in this study was life history interviews. Watson and Watson-Franke wrote; "Life history is any retrospective account by the individual of his life in whole or part, in written or oral form, that has been elicited or prompted by another person." ${ }^{75}$ Furthermore, Tierney notes that "life history is related to biography, it is a retrospective account, and it involves some form of narrative statement." ${ }^{76}$ In an influential work on narrative research, Donald Polkinghorne wrote: Narrative is a scheme by means of which human beings give meaning to their experience of temporality and personal actions. Narrative meaning functions to give form to the understanding of a purpose to life and to join everyday actions and events into episodic units. It provides a framework for understanding the past events of one's life. . . It is the primary scheme by means of which human existence is rendered meaningful. ${ }^{77}$

The life history methodology was best suited for this study because it permitted the participant to develop and recall her story as she remembered it. The interviewing process included one or more scheduled interviews (this included telephone and face-toface interviews) with the interview being tape recorded and transcribed by the interviewer. Interviews were not formally bounded by time constraints, though participates were asked to set aside two to three hours, in part, because of the distance I traveled on some occasions, but also because this length of time permitted a more conversational approach to interviewing that let the interviewees, themselves, rather than

\footnotetext{
${ }_{76}^{75}$ Tierney, "Undaunted Courage," 539.

${ }_{77}$ Ibid.

Polkinghorne, Narrative Knowing, 11.
} 
Chapter Three

a formal interview protocol structure the interview process. The two to three hour time frame, in short, represented an attempt to follow Mishler's admonition to "invite... [participants] into... [your] work as collaborators, sharing control with them, so that together...[you] try to understand what their stories are about." ${ }^{78}$ To state this point another way: the length of time was "in the interest of giving greater control to respondents."

Interviews were semi structured. An interview guide was used, largely to initiate the interview and to check for coverage at the end of the interview period. (Refer to Appendices B and C for survey questions.) During most of the interview time, however, the interviewees normally took the lead in structuring what often seemed to be more a conversation than an interview.

In short, throughout the interview process, I attempted to engage in a delicate balancing act. On the one hand, I attempted to heed Max Van Manen's caution about open ended/conversational interviewing. Van Manen argued that the interviewer must not initiate the interview "without first carefully considering what interest the interview is to serve." ${ }^{80}$ In conjunction with having a clear intent for the purpose of the interview, he underscored that "the interview process needs to be disciplined by the fundamental question that prompted the need for the interview in the first place. ${ }^{81}$ Conversely, I tried not to lose sight of Fontana and Frey's argument that "unstructured interviewing can provide a greater breadth of data than the other types, given in qualitative nature. ${ }^{82} \mathrm{My}$

\footnotetext{
${ }_{79}^{78}$ Ibid., 164.

${ }_{80}^{79}$ Riessman, Narrative Analysis, 55.

${ }_{81}^{80}$ Van Manen, Researching Lived Experience, 66.

${ }_{82}$ Ibid., 66.

Fontana and Frey, "The interview," 652.
} 
challenge throughout the interviewing process, in other words, was to maintain direction without interfering in the conversational nature of the interview. Since the purpose of every interview in this study was to discover how participants "impose order on the flow of experience to make sense of events and actions in their lives" ${ }^{83}$ and "give meaning to their experience of temporality and personal actions," Fontana and Frey side of the tightrope I was continually walking.

Initial interviews began with the following open-ended question: Would you tell me what it was like being the wife of a POW or MIA? (Interviews conducted with governmental officials or military personnel also began with the open-ended question: Would you tell me what you knew about the activities of the wives of POW and MIAs and the National League of Families?) A preliminary study with three POW wives conducted in preparation for doing this larger dissertation study demonstrated that my initial question for the women elicited a narrative response lasting from one to two hours. I intentionally began the interview with an open-ended question to avoid unduly framing what respondents told me. Often an interviewee's (often lengthy) response to the initial questions generated additional questions in my mind that were not on the interview guide I had developed. When this happened, I asked these interviewee-generated questions and only referred to the questions on the interview guide near the end of the interview time to be sure that areas that I wanted to cover had, indeed, been covered in the more-or-less natural conversation the interviewee and I had been having.

I did insert one other predetermined task into the interview. I asked each

\footnotetext{
${ }_{84}^{83}$ Riessman, Narrative Analysis, 2.

Polkinghorne, Narrative Knowing, 11.
} 


\section{Chapter Three}

interviewee to construct a timeline of key events that they recalled. The pilot study had revealed that the three women interviewed tended to recall their stories chronologically, beginning with the date of when their husband was shot down. I wanted to access each of the interviewee's sense of the chronology and the key events they recalled in their chronological accounts because, at the time, I had assumed that the history I would write would be organized almost entirely chronologically.

For the most part, however, the interviews were more structured by the interviewees than the interviewer. To be sure, this somewhat improvisational type of interviewing process can and did have a level of frustration associated with it. Rubin and Rubin have noted that researchers who employ the interview strategy used in this study must "have a high tolerance for uncertainty ... because the design will continue to change as the researcher hears what is being said." Rubin and Rubin also write, however, that the approach to interviewing used in this study also "generates tremendous excitement because you have to do so much thinking on the spot and because there is genuine delight when you discover something new." ${ }^{85}$ After nine months of interviewing, I found myself agreeing whole-heartedly with both of Rubin and Rubin's points.

One final point about the interviewing process: After interviews were completed and transcribed, all participants were provided a copy of their interview to review, edit, or clarify their story via written input or additional conversation with the interviewer. No participant made substantive changes to what they had said initially. Changes were either grammatical, or they elaborated on or further clarified what had been said initially. After the dissertation defense, chapters 4-8 were sent to the POW and MIA wives who

$$
{ }^{85} \text { Ibid., } 41 .
$$


participated in the reseaerch project. Four reviewed all the chapters sent, two reviewed portions of each chapter, and three women, were not able to review the material by the deadline required. Overall the recommended changes were were corrections with names, for example, Roberts to Robertson and Mae Rose to MaeRose and a clarification of location in one instance.

Analysis of Data

At the outset, I think it is critically important to recall the admonition written by Riessman: "The challenge is to find ways of working with the texts so the original narrator is not effaced, so she does not loose control over her words." ${ }^{86}$ To achieve this, as best as I could, I combined analysis methods suggested by Jerome Bruner, on the one hand, and Donald Polkinghorne, on the other.

Though Bruner does not provide a formal analysis methodology with carefully articulated sequential steps, he nonetheless addresses specific issues in narrative research that are to be taken into account "to show how human minds and lives are reflections of culture and history." ${ }^{87}$ These include such key concepts as cultural sensitivity, symbolism, ontological belief, constituency, protagonist, framing, and turning points. These concepts were very much in the back (and often in the front) of my mind as I engaged in the lengthy and complex analysis process. Fortunately, the work of Donald Polkinghorne has taken Bruner's thinking and translated it into somewhat more procedural terms.

Donald Polkinghorne's article, Narrative Configuration in Qualitative Analysis, ${ }_{87}^{86}$ Riessman, Narrative Analysis, 34.
Bruner, Acts of Meaning, 138. 
Chapter Three

describes two analysis processes, which he refers to as the analysis of narrative and narrative analysis. The analysis of narrative process involves subsuming the individual stories told by the researcher's participants under coding categories and then reporting the narrative data thematically rather than as a chronological story. This is the traditional approach to analysis used in qualitative research within the social sciences.

Because I was writing a history, my plan was to the alternative analysis strategy Polkinghorne articulated and named narrative analysis. Essentially this process reconfigures data into a chronological storyline using the literary elements of plot. Or, to use Polkinghorne's words, the researchers' responsibility is to "collect descriptions of events and happenings and synthesize or configure them by means of a plot into a story or stories." ${ }^{88}$

Polkinghorne noted that, during the interview process, participants normally tell their stories in a variety of ways, only some of which entail chronology. The task of the researcher engaged in narrative analysis is, according to Polkinghorne, "to configure the data elements into a story that unites and gives meaning to the data as contributions to a goal or purpose." ${ }^{89}$ A critical analytical task is for "the researcher to develop or discover a plot that displays the linkage among the data elements as parts of an unfolding temporal development culminating in the denouement." ${ }^{90}$ This requires an integrating operation that Polkinghorne refers to as the "emplotment." ${ }^{91}$ As a result, when human activities and events are "configured or emplotted, they take on narrative meaning [and] are understood

\footnotetext{
${ }_{89}^{88}$ Polkinghorne, Narrative Configuration in Qualitative Analysis, 12.

${ }_{90}^{8}$ Ibid., 15.

91 Ibid., 15.

Ibid., 5 .
} 
from the perspective of their contribution and influence on a specified outcome." Polkinghorne's initial method to achieve this was as follows: (a) list all events from the stories, (b) highlight and recognize the contributions of certain events to the outcome, and (c) determine how these events gleaned from the second stage are interrelated and interconnected. $^{93}$

Polkinghorne emphasized that "data does not follow an algorithmic outline, but moves between the original data and the emerging description of the pattern." Polkinghorne attempted to choreograph this back and forth movement in his seminal article Narrative Configuration in Qualitative Analysis, by articulating a number of strategies researchers engaging in narrative analysis could use. These strategies include the following:

- Discovering and developing a plot that displays linkage among the data elements.

- Relating of events and actions to one another by configuring them as contributors to the advancement of a plot.

- Describing events and happenings diachronically.

- Constructing a plot outline.

- Organizing data elements into a coherent development account.

- Synthesizing of events into an explanation of the specified outcome.

${ }_{93}^{92}$ Ibid., 5 .

${ }_{94}$ Ibid., 5.

Polkinghorne, Narrative Knowing, 177. 
Chapter Three

- Searching for pieces of information that contribute to the construction of a story. 95

Polkinghorne also emphasizes that data other than interview data "that contribute to the construction of a story" ${ }^{196}$ need to be a part of narrative analysis and included in the story that narrative analysis yields. In this study, these other data included the records and documents alluded to above.

Polkinghorne wrote that "a narrative configuration is not merely a transcription of the thoughts and actions of the protagonist; it is a means of making sense and showing the significance of them in the context of the denouement." ${ }^{97}$ Because of this, Polkinghorne endorsed the use of Dollard's criteria for judging life history research in narrative analysis. These criteria include the following:

- The researcher must include descriptions of the cultural context in which the storied case study takes place.

- The researcher needs to attend to the embodied nature of the protagonist.

- The researcher needs to be mindful not only of the general cultural environment and the person as embodied, but of the importance of significant other people in affecting the actions and goals of the protagonist.

- The researcher needs to concentrate on the choices and actions of the central person (the protagonist).

- The researcher needs to consider the historical continuity of the characters.

\footnotetext{
${ }_{96}^{95}$ Polkinghorne, Narrative Configuration, 15-18.

${ }_{97}^{9}$ Polkinghorne, Narrative Configuration, 18.

Ibid., 19.
} 
Methodology

- The researcher must mark the beginning point of the story and the point of denouement (bounded temporal period).

- The researcher needs to provide a story line or plot that serves to configure or compose the disparate data elements into a meaningful explanation of the protagonist's responses and actions. ${ }^{98}$

As noted, I had planned to use the narrative analysis procedures outlined by Polkinghorne and articulated above (along with the considerably more general constructs articulated by Bruner) to analyze the data in this study. To a large extend, I did this. Dollard's criteria were especially helpful as formative evaluation tools as the historical account was being constructed.

I discovered, however, that, with the sort of data set employed in this study, the process of narrative analysis was considerably more complex than Polkinghorne's procedural description suggests. To state this another way: there were multiple subplots in this story. Furthermore, as was noted previously, the women, themselves, often organized their stories more thematically than chronologically.

In part to adequately represent the women's voices-but also to accommodate the complexity of the data - I found myself employing a kind of hybrid of chronological and thematic organization. Chronology was the overarching organizational device, but the chronological account frequently needed to be interrupted to explore ideas in ways that were closer to what Polkinghorne calls the analysis of narrative as opposed to narrative analysis. In this study, the women who were interviewed suggested the themes that were

${ }^{98}$ Ibid., 15-18. 


\section{Chapter Three}

addressed. To summarize, in this study, Polkinghorne's two approaches to analysis were more complimentary than distinct.

I also found the need to tell multiple stories and to cover the same ground from a different vantage point. As noted above, the most obvious example of this is the findings chapter, Chapter 7, which covers the same material covered in earlier findings chapters, but this time from the perspective of government officials. Attempting to integrate everything into a single, unified story was simply too difficult to do rhetorically. Had I tried, I feel sure I would have simply confused the reader.

There is one other analysis decision that should be mentioned. The life history data could have been presented either individually (the custom in life history research) or collectively. In other words, I could have chosen to present each participant's individual story or reconfigure the individual stories into one composite story.

Each approach had advantages and disadvantages. The individual story approach would have made for an easier analysis process and, almost certainly, an easier "read" for the consumers of this research. In the end, however, I opted for the composite approach, in part because the individual approach had already been used in much of the literature that was reviewed in Chapter 2. Furthermore, the composite approach permitted the integration of the governmental reaction to what the women and their organization did. Integrating this material was essential for answering a question that many of the women continued to ask themselves: Did they really influence policy?

\section{Limitations}

There is a need to acknowledge the limitations within this study's use of life history methodology. First, the narratives are, in the words of Riessman, "limited 
portraits" that "we are interpreting and creating texts at every juncture, letting symbols stand for or take the place of the primary experience, to which we have no direct access." ${ }^{99}$ Second, the transcribed narrative text represents a partial reality. Riessman wrote that a story, which has been given to the researcher, often comes with additional interpretative elements. Third, any attempt to generalize from this study must take into account the unique cultural, gender, and generational issues. All the participants were the wives of career military officers and their stories are derived from the mid-1960s. As will be suggested in this dissertation's final chapters, the study can yield heuristics to guide thinking; it cannot provide formulas for action.

Beyond the methodological issues described above, a possible limitation was that I am a male, which might introduce unknown variables on the way the women responded to my questions and the way I framed additional quesetions based on their comments. Furthermore, I grew up during the Vietnam War and had acquired a knowledge of the POW and MIA issue while in junior high and high school. After after the prisoners were repatriated I continued my intereset by reading books and articles written by or about the men. Certainly, I bring my situational frame of reference to the research. Bringing this frame of reference has benefits but also limitations.

Finally, the sample of women was predominantly taken from Navy wives, which, can be argued, tilts the story toward a "Navy" perspective. Furthermore, mothers and fathers of single men who were listed as POWs or MIAs were not interviewed. This was not intentional, but due to the passing of four decades most parents involved with the National League of Families are deceased.

${ }^{99}$ Riessman, Narrative Analysis, 15. 
Chapter Three

\section{Significance of the Study}

There is significance to the study for several reasons. First, for historians it provides the first known collective body of life histories from women whose husbands were listed as POW or MIA in Vietnam. There are ample documents and records produced by and about the prisoners while the same regarding the women is regrettably insufficient. Second, for political scientists, it provides an account of the development and influence of a minority group of citizens who became public activists to challenge governmental policy and policy makers. Third, for those in leadership studies, the research focused on citizens, without formal power or legitimate authority, who, while adapting to circumstances and situations, exerted influence on policy makers for a policy change. Their actions demonstrated that, at least under certain circumstances, citizens can mobilize and influence a large spectrum of society and governmental officials to take action when a policy is shown to be destructive and detrimental to other citizens. To state this another way: It is possible to lead, even in the national and international policy arenas, in the absence of positional power or when one does not have the resources normally used to purchase access to power and influence those with formal authority to act. 
Chapter Four: The Rise of the Reluctant Sorority

"I think it's an example of unconditional love. It is what it is.

It isn't altered by some superficial reality."

Karen Butler

Rekindling of Support and Remembrance of Past Days

"The bonds formed 35 years earlier had been stretched but not broken."

Jenny Connell Robertson

On a sun-drenched Sunday afternoon in April 2005, I gathered with a group of ten women on backyard porch in Coronado, California. Approximately thirty-five to forty years earlier, these women's lives - and the lives of a number of other women across the United States — had been inextricably linked. ${ }^{100}$ These were young women, some were newly married, and some had infants or young children. The experiences that linked them together are undeniably unique and without parallel, because, between 1965 and 1973 , world events thrust these women into the policy arena where they became a potent political force that influenced world events and made even the most powerful men in the world attend to their collective agenda.

The world event alluded to in the previous paragraph was the Vietnam War. The women were wives of military officers, mostly pilots, captured by the North Vietnamese

${ }^{100}$ It is important to acknowledge the work and participation of numerous mothers, fathers and family members of single men who were held captive in or listed as MIA in South and North Vietnam. Even though this research project focused on the wives of POWs and MIAs, I acknowledge the importance of their contribution to the POW and MIA issue. 


\section{Chapter Four}

or the Viet Cong and were listed as Prisoner of War (POW), or if their status was

unknown, they were classified as Missing in Action (MIA).

All of this had happened a long time ago, of course. The first prisoner of war, in fact, was shot down and captured in 1964 and by March 1973, all known prisoners were released. ${ }^{101}$ For the women who gathered on that sunny Coronado porch thirty-two years after the release of the final prisoner - and a number of other women who were not physically present but who were present in spirit-the memories of what had happened, were still fresh.

They remembered in visceral detail when they were told that their husbands had been captured or were missing. Some remembered the joy of their husband's return.

Others, like the vibrant, smiling, and "little package of dynamic" as other wives have described her, Jenny Connell Robertson remembered the absence of a happy ending. "For those whose husband's came home," Jenny told me, "it was a joyous occasion. For the rest of us, our lives had to take a different path."

They also continued, these many years later, to remember what they had accomplished together and the support they provided each other during difficult times. Sherry Martin, one of the POW wives, referred to the group, during an interview with me, as "the reluctant sorority." She quickly added: "Nobody wanted to join."

Three decades later, the "sorority sisters" still look to each other for support. The support effort was rekindled in 2002 when Jenny Connell Robertson's second husband died of Alzheimer's. Unknown to her, Marie Estocin—a woman considered by others as

101

There has been ample national debate regarding the possibility of prisoners being left in Southeast Asia along with a full accounting of MIAs. Between 1978 and 1991, the House Committee on International Relations, Subcommittee on Asian and Pacific Affairs, held hearings on POW and MIA matters. In 1991 and 1992, the Senate Select Committee on POW and MIA Affairs held hearings. 
The Rise of the Reluctant Sorority the group's Rock of Gibraltar — contacted other wives to inform them about Jenny's husband's death. Jenny said she was "dumbfounded" when she saw friends she had not seen in years at her husband's funeral. She said, "It was as if the safety net had been reformed and I felt secure in that support." It was then, as Jenny recalled, that the group pledged "not to let that much time pass again" before they get together.

The women now gather every other month. The April 2005 gathering was the third gathering in nine months I was able to attend. At each of the gatherings I attended, I heard the women talk of past hardships without dwelling on personal pain. I listened as they exchange information about other women who had once been part of the group and I heard how everyone obviously still cared deeply about these women from the past. Their friendship defies definition or adequate description. Their love and admiration for one another is unmistakable. The protection of their bond is evident and their passion to maintain the rekindled friendship does not dim.

I saw and heard all of this. But, mostly I heard them laugh! Their laughter was contagious and exuded warmth. Considering the odyssey of their lives, their sense of humor is remarkable and a testimony to the resiliency of their spirit. A few days after the gathering on April 2005, Jenny told me, "The level of emotional support and trust exhibited in this group of women is unique. Words cannot convey the depth of that bond."

I left the April 2005 gathering with a sense of having been in a holy place - a holy place of sacred memories. What follows is a brief glimpse behind the curtain of these women's holy place. 


\section{Chapter Four}

As this chapter and the three that follow it unfold, the reader must understand that the story told is not just a personal story. The story is also about a turbulent period in this nation's history and the wives' struggle to exercise power and influence in the absence of formal positional authority or the resources normally required to impact policy these turbulent times. The story begins with a brief article in the August 6, 1964, issue of the New York Times.

Historical Context of the Prisoner of War and Missing in Action Issue

"The people and the government of the Democratic Republic of Viet Nam consider the ... pilots who have carried out pirate raids, destroying the property and massacring the population of the Democratic Republic of Viet Nam, as major criminals caught flagrant delicto [sic] and liable for judgement [sic] in accordance with the laws of the Democratic Republic of Viet Nam, although captured pilots are well treated."

Letter from the Democratic Republic of Vietnam (North Vietnam), provided by the International Committee of the Red Cross, June 1965

"I really think the cultural setting is important. I really do.

I think you have to understand the times. The cultural setting explains it a little bit."

$$
\begin{gathered}
\text { Jenny Connell Robertson, Wife of POW } \\
\text { "I'm a product of the '50s." } \\
\text { Sherry Martin, Wife of POW }
\end{gathered}
$$

Emergence of the Issue

On August 6, 1964, the New York Times published a short 135-word article that reported an incident that would eventually thrust an obscure but influential governmental 
policy into the public arena via a most unlikely group. The event was the shooting down of an American Navy pilot, Lieutenant Junior Grade (LTjg) Everett Alvarez Jr. and his subsequent capture by the North Vietnamese. As the war in Vietnam escalated during the mid to late $1960 \mathrm{~s}$, the number of military aircraft shot down over North Vietnam resulted in a growing number of American aviators classified as POWs or MIAs.

Eventually, this group of POWs and MIAs became a significant factor in negotiations between the United States and the North Vietnamese to end the Vietnam War. For example, a National Security Council memorandum, dated February 22, 1971, from John Holdridge, Staff Member, National Security Council (1969-1973), to Dr. Henry Kissinger, Assistant to the President for National Security Affairs, discusses a comment made by Vitaly Petrochenko, Deputy Editor of the Soviet magazine $U S A$ to $L A$ Times correspondent Stuart Loory. Holdridge noted in his memo that Mr. Petrochenko had indicated that the North Vietnamese "would be willing to ransom the American POW's for a billion dollars." Mr. Holdridge commented to Dr. Kissinger "it is highly improbable that the North Vietnamese would, for any amount of dollars, sell a bargaining counter as valuable as the American POW's." ${ }^{102}$ Whether or not Holdridge's assessment of Petrochenko's comments was accurate, what Holdridge wrote to Dr. Kissinger clearly demonstrated that the POWs had become a significant factor in the negotiation process.

The POWs and MIAs became a factor — and even a bargaining chip—in large part because of the visibility of the POW and MIA issue. This visibility was essentially the result of the actions from a tenacious but unlikely group of actors in the policy arena: the

${ }^{102}$ John Holdridge, Member, National Security Council, to Dr. Henry Kissinger, Assistant to the President for National Security Affairs, Washington, DC, Feb. 22, 1971; White House Central Files; ND 18-3 Prisoners; 1/1/71 [1972]; Nixon Presidential Materials; National Archives at College Park, College Park, MD. 


\section{Chapter Four}

wives of POWs or MIAs. To achieve such a position of influence, the wives had to transcend an array of cultural and personal taboos.

\section{The Cultural Context and Women's Roles}

During my interviews with POW and MIA wives and other influential political actors at the time, various individuals mentioned the era and its influence on the events, which are the focus in this research. Several acknowledged that, at the time, women's roles were changing domestically, professionally, and within the military culture. Richard Capen, Deputy Assistant Secretary of Defense for Public Affairs during the Nixon administration, rightly noted that most of the husbands and wives in the military "were career people. ${ }^{103}$ Wives of military officers, he observed, thought of themselves and their husbands as inseparable from a career standpoint. This career mindedness, he noted, established a great sense of patriotism, support of Presidents, and a clear understanding of the risks involved with military service.

Jenny Connell Robertson, on the other hand, suggested that Capen's characterization of military families was more typical of the times than a unique characteristic of military families. She spoke about the generational expectation for all wives, not just military wives, was to stay at home and raise the children while husbands went to work.

An unintentional consequence of such a traditional mindset, however, manifested itself when the wives received notification of their husband's imprisonment or missing in action status. Richard Capen noted that this dual element of career and culture made the

103

In 1971, Richard Capen was awarded the Department of Defense's Distinguished Service Medal, in part, for his work on behalf of POWs in Vietnam. 
The Rise of the Reluctant Sorority

wives "hesitant to say a lot because they didn't know whether it was going to help get information on their husbands or whether it would hurt their lives."

Comments made by Sherry Martin, who was thirty-three years of age with two children when her husband was shot down in 1967, reinforced Capen's point. She recalled that, for the most part, the wives cultural mindset toward military or governmental officials was based on trust in those assigned to positions of authority. With unabashed candor she said, "I'm a product of the 50's. I can't speak for all of us, but a lot of us never question authority. If authority said, 'This is the way you do it' [then] this is the way you do it. We weren't challenging. We respected authority figures because they [the people in authority] got there somehow."

In short, Sherry indicated that she — and many other military wives_-"figured . . . [government officials] certainly knew a lot more" than she and the other wives did. After all, most government officials were highly educated, which lead Sherry and others to other assume that education equated to a sense of trustworthiness and conferred a sense of legitimate authority. In time, however, she and the other wives learned such an assumption was not "always the case."

While some aspects of Navy culture (and, to some extent, the general culture of the times) needed to be transcended before the wives could become a potent political force, Sherry provided an additional insight about the military culture that turned out to be a facilitating factor in the transition process. Sherry noted that, in the military, spouses often take on leadership roles and assume positional authority based on their husband's rank. Sherry actually seemed a bit conflicted about this cultural norm. At one point, for instance, she indicated that she did not support the concept of a wife "wearing her 
Chapter Four

husband's rank." At another time, however, she posed a question to me that seemed more rhetorical than real: "Don't you defer to the Commanding Officer's wife?" Clearly, the military culture had taught Sherry that the answer to this question was, obviously, yes. This was made clear in her comments about the role of the Commanding Officer's wife when she told me, "I would expect her to take the leadership."

Bonnie Singleton, a relatively inexperienced twenty-three year old when her husband was shot down, made a similar point. A couple of years after he husband was taken prisoner, she recalled that she took her cue from Sybil Stockdale, the wife of the ranking senior officer among the group of captives in Hanoi. Sybil Stockdale, herself, during one of my interviews with her, also took note of the Navy tradition of officer's wives exercising leadership to a degree that was commensurate with their husbands' rank. Jenny Connell Robertson, as well, spoke of the Navy tradition of deferring to the senior officer's wife. It was her conviction that this element of Navy culture and tradition, along with other aspects of the Navy's rigid traditional culture, were enabling factors for the wives during their transition from military wives to influential political activists.

For many of the wives, however, Navy traditions also constrained, especially when they were reinforced by the prescribed gender roles of the larger culture. On the other hand, Karen Butler-who told me that even in the 1960s she "was still a product of the '50s"- suggested that the larger cultural context also inadvertently pushed women beyond their traditional roles once their husbands were listed as a POW or MIA. She recalled, with laughter, how she was "turned down for a house to rent in La Jolla [California] because [she] was a married woman without a man." Sybil Stockdale--who, in part because of her positional power but also because of her keen intelligence and 
The Rise of the Reluctant Sorority

personal charisma was the impetus, genius, and mastermind of the wives political activism-had a newspaper article in her personal files that suggested the situation that Karen Butler was forced to confront and deal with was hardly unique. The article was from the August 8, 1966, edition of the New Haven Register; it described the "legal limbo" a wife was thrust into when her husband's status was POW or MIA. ${ }^{104}$ The article illustrated the problem with several stories; one of a woman required to sell the family car because she could not obtain her husband's signature for new license plates, another of a federal tax bureau that refused to process a joint tax return until the POW wife obtained the signature of her husband.

These stories, and others, illustrated the inability of women to conduct basic business transactions while living in conformance to societal and military expectations of behavior and existing social mores. This inability to conduct business transactions, however, forced on many women new roles that prepared them for the more public and high-stakes role in the public policy arena they would eventually participate in. Still, even with the dress rehearsal opportunities provided by rigid and inflexible bureaucratic requirements, it is important to understand how difficult it was for most of the women to take on this new role. As Richard Capen said to me:

It wasn't a natural thing for women to be taking a mic and blasting anybody, or, going to Paris and demanding to see the Peace Negotiators from North Vietnam. It's an era when women were not as deeply involved in leadership roles in business or government. The whole issue of women's rights and the comfort of women to speak out on issues were very different and limited.

${ }^{104}$ Sybil Stockdale, unpublished data, private collection. 
Chapter Four

During my interview with Jenny Connell Robertson, she reinforced the point made by Capen. She noted that the transformation to being a public figure within the policy arena contradicted the prevailing societal etiquette of the day and the traditional way of rearing women. Consequently, she remembered the transformation process as "being painful in some ways. . . . It might have put you in situations you particularly didn't want to be in." Nevertheless, she also recognized the transition "had positive and negatives at the same time" because it "forced" the performance of various activities on behalf of the men in Hanoi and those who were missing. Additionally, Jenny spoke about how the transformation developed into an adventure of self-discovery. It led, she said, to "finding out about yourself pretty quickly; what kind of person you're made of and can you make it through this." She and the others did not know at the time the immense skill and internal fortitude required to deal with such a behemoth bureaucracy as the Untied States government. In time, however, they learned this lesson well. The Government's Prisoner of War Policy: Whose Policy Is It, Anyhow? "Isn't everybody in this government working together?"

\section{Sybil Stockdale}

One of the wives internal contacts within the Navy was Commander Robert (Bob) Boroughs, Naval Intelligence. Now deceased, Commander Boroughs not only provided a sympathetic ear to the wives but also was an individual of strategic importance in mediating between the women and various governmental officials and departments. On occasions, he advised and/or recommended courses of action to further the goals of the women-as well as help the Navy. Sybil Stockdale, whose husband had been in prison since September 1965, recalled that Commander Boroughs broached the subject about 
The Rise of the Reluctant Sorority her engaging in covert communications with her husband as a confined prisoner in Hanoi. This act alone was fraught with danger and serious consequences if discovered by prison authorities. At the same meeting when the covert communication was discussed, Commander Boroughs also asked Sybil to pay a courtesy call on Ambassador Averell Harriman, President Johnson's ambassador-at-large for Southeast Asia affairs, at the Department of State. Sybil responded by asking why he wanted her to see him.

Commander Boroughs replied, "I'd like to know what he tells you." Years later, Sybil told me her response to Boroughs question, "Isn't everybody in this government working together?"

The dialogue between Sybil and Boroughs was a glimpse behind the governmental bureaucracy of two major agencies - the Department of State and the Department of Defense - and an indicator of the breakdown in communication between these two agencies, and the distrust that often existed between them. Contrary to what most wives thought, the Department of Defense was not in charge of POW matters. Rather, responsibility for the POW matters had been delegated to the Department of State. Primarily, this was due to the prevailing belief that the prisoner matter was a diplomatic function requiring Department of State authority and expertise. However, this was questioned months before LTjg Alvarez was shot down over North Vietnam by the Joint Chiefs of the military. The Joint Chiefs sent a formal memorandum on February 26, 1964, to Robert McNamara, Secretary of Defense, expressing their concerns about the status of POW matters, the current POW policy, and the limited involvement of the Department of Defense in POW matters. 
Chapter Four

Defense and Department of State senior officials reviewed the memorandum, which was also circulated to other agencies, including the Central Intelligence Agency. The staffing process sought advice and information for an appropriate response to the Joint Chiefs. The ensuing communiqués between the State and Department of Defense officials, documented in the book, The Long Road Home: U.S. Prisoner of War Policy and Planning in Southeast Asia by Vernon E. Davis, revealed the continuing disagreement about which governmental agency should be delegated the responsibility for dealing with the growing POW issue. The communiqués revealed that the Department of Defense officials remained skeptical about the resolve and commitment of the Department of State to deal with the POW problem in ways that officials in the Department of Defense deemed appropriate.

In November 1965, after twenty-two months of study and discussions between State, Defense, and the CIA, and after further appeals by the Joint Chiefs of Staff to the Secretary of Defense, Defense Secretary McNamara replied to the Joint Chiefs of Staff. He informed the Joint Chiefs that the Department of State had completed its review of their memo but he decided he would not change the diplomatic approach to the handling POW issue. He then indicated that Defense and State were exploring the effectiveness of a "demarche" to the Soviet Union. By the time the staffing study concluded, the number of United States prisoners in South and North Vietnam numbered over seventy.

Tragically, the North Vietnamese maintained a position that the men held captive were not to be accorded humane treatment or given proper care as specified by Geneva Convention Relative to the Treatment of Prisoners of War. The North Vietnamese maintained this position even though they had signed the agreement. 
Geneva Convention Relative to the Treatment of Prisoners of War

"It was sort of a forgone conclusion-we knew they were being maltreated."

\section{Sherry Martin}

Over three decades later, the women I interviewed for this study were quite familiar with the contents of the Geneva Convention Relative to the Treatment of Prisoners of War, adopted in August 12, 1949. This knowledge had been purposefully acquired and effectually used. During one of my interviews with Sybil Stockdale, for example, she noted: "I had invested a tremendous amount of my time educating myself about the subject." This education process included writing a letter to Vice Admiral B. J. Semmes, Jr., Chief of Naval Personnel, requesting "a bibliography which," she wrote, "will allow me to learn as much as possible about any and all aspects of the conditions and people with whom my husband may be 'associating."' ${ }^{105}$

Although the women had transformed themselves into experts on the Geneva Convention, not all of the key government actors possessed such expertise. In preparation for our interview, for instance, Phyllis Galanti, who had been a young Navy wife of twenty-five and mother of two little boys when her husband was captured, reviewed the personal records she had kept. Phyllis discovered in her notes taken from a meeting that she and some of the wives had had with Dr. Kissinger that she "registered [her] horror" regarding his apparent lack of in-depth knowledge about the Geneva Convention. Until she prepared for the interview, she said, it was something she had not remembered.

Though Secretary Kissinger may not have been familiar with the Geneva

105

Sybil Stockdale to Vice Admiral B. J. Semmes, Jr., Chief of Naval Personnel, Coronado, CA, Sept. 17, 1965, unpublished data, private collection. 


\section{Chapter Four}

Convention agreement on prisoners of war, the wives knew, and used, specific key components from the Geneva Convention (Appendix D). Even though the North Vietnamese were signers to the Convention, they refused to abide by the provisions due to their opinion that the conflict in Vietnam was not a declared war by the United States Congress. This interpretation led to a whole host of abuses on the POWs. For instance, many pilots, when captured, did not receive protection from violent acts or insults by the local populace; they also were tortured in prison and used as instruments for propaganda purposes. In addition, they were not provided with adequate food, health care, sanitary conditions. The North Vietnames also did not permit inspections of prisoners and facilities by the International Red Cross. All of these things were required by the Geneva Convention agreement.

In spite of such abuses, the American government maintained publicly that the men were well treated and in good health. This storyline, which became the official position, was repeated to the wives during the notification process about their husbands' capture and imprisonment. The wives, however, quickly learned the real story and - as it will be shown-when they became activist and told the real story publicly, they invoked the Geneva Convention Relative to the Treatment of Prisoners of War to raise public awareness about the POW issue. Among other things, they correctly noted that Article 2 of the Geneva Convention mandated that the Convention apply in cases of declared war or armed conflict "even if the state of war is not recognized by one of them." Therefore, they argued, international law dictated that their husbands receive the sort of treatment spelled out in the Geneva Convention Articles. 
Changing Status, Stark Realizations, and Requisite Adjustments

\section{Official Notification of Husband's Status}

"We need to talk to you."

Spoken to Marie Estocin by Official Notification Party

"If someone had asked me if I would like to be a POW wife;

I probably would not have accepted the job."

\section{Chloe Moore}

The first question I asked the wives was a grand tour question-"Would you tell me what it was like being the wife of a POW or MIA?" This question allowed them to formulate their own narratives and to recall elements of their stories that left indelible impressions on their hearts and minds. All thirteen of the interviewed women began their discussions by describing notification process. For some the memories of the notification brought forth tears; some looked in a different direction; some had a momentary pause, and for most, there was a simple but deep verbal sigh.

All the women invariably recalled the notification process in detail. They remembered the type of day, what they were doing, whom they were talking to, the "black car" (black was the color of military vehicles conducting official business, including notification of a husband's capture or death—in short order the black car became a symbol of bad news), the individuals who delivered the news, and the bewildering and lingering feelings of numbness.

All of the stories were the same, yet each was also unique. Marie Estocin, a young mother of two and one of the wives who endured several status changes of her husband 


\section{Chapter Four}

during and after the war, had just laid down her daughters for their afternoon nap. ${ }^{106}$ After laying the girls down, she had decided that this was a good opportunity to go outside, sit in the sun, and read a book. She was just settling down with her book when the doorbell rang. When she opened the door, she saw the Commanding Officer of the base, the chaplain, and the squadron skipper's wife. Instantly she knew why they were there. To forestall the news, she instinctively slammed the door and ran into the back room. Those that had come to speak with her found her huddled by the washer and dryer in the laundry room. Graciously they said, "Let's come out into the living room; we need to talk to you." A mother of just two months, the self described pragmatist of the group, Karen Butler, heard a knock on the door at six thirty in the morning. Because of the makeup of the group on her porch, she "knew exactly what it was." She remembered-both at the time and decades later - that the wife of the casualty officer standing on her porch and delivering the bad news had, just two months before, shared a maternity room when their children were born.

Like many of the women, both Marie Estocin and Karen went through the notification process more than once because of changing reports from commands overseas, or later from intelligence reports. For both their husbands were initially listed as "presumed dead."

Bonnie Singleton also received multiple notifications, but in her case the notification was nor in person. She received telegrams; the first informed her that her husband was MIA; then fourteen months later she received a second telegram that

\footnotetext{
${ }^{106}$ Marie Estocin's husband's status changed from MIA to POW, to Presumed Finding of Death (PFOD).
} 
notified her that her husband was a POW. The first telegram brought shakes, trembling and sleeplessness; the second brought confusion because she did not have access to the "sufficient evidence" that caused the military to change her husband's official status. All she had as a cursory telegram.

After the initial notification, most of the wives developed a mental plan for coping and functioning in their new role. Though it would be difficult, Sherry Martin believed she could cope with her new role and situation. As a mother, she said, she did not have any other choice because her children needed care regardless of the circumstance. For Mary Winn, whom Sybil Stockdale considered an "intelligent and persistent lady," the new role would be guided by her conviction that it was her responsibility to represent her husband "well in all I did and said and in the way I looked — not sad but hopeful and solid — cheerful but not silly in the face of adversity. ${ }^{107}$ Her operative word was "calm," which would ensure her not going "to pieces."

Chloe Moore - a wife who afforded many other wives moments of laughter and was known as one who did not seek credit for the work done- - responded by mixing a blend of humor and pragmatism. She told me she "wasn't given a choice" when it came to being a POW wife. She immediately recognized, however, that "it was a matter of having a family to take care of and going about ... [her] business." This business included signing a new teaching contract each school year with the thought, "He'll be home by then ... one more year." She signed six contracts before her husband's return but, as she said, "You just live and tell yourself, 'I can do another year.'"

${ }^{107}$ Sybil Stockdale and Mary Winn were close in age and background, which contributed to an instant friendship. They used each other as a sounding board to vet ideas; especially ways to bring pressure on the governments of North Vietnam and America, as well as ways to publicize their story to millions of Americans. 


\section{Chapter Four}

Overtime, the wives found each other and became, in Sherry Martin's word, "the reluctant sorority." The "sorority" was more an informal than formal organization. The wives' common experiences and a number of emergent rituals held it together. One of these rituals involved remembering the date that each of the others wives' husbands had been shot down. Even thirty-two years later, the women I interviewed remembered these dates.

An emergent factor that also held the group together was a shared distaste for the government's policy that dictated government officials' response to the POW and MIA issue. The government, during the Johnson administration, labeled the policy, "Quiet Diplomacy." To the women, however, it was the "Keep Quiet" policy.

\section{A Common Remembrance: The Keep Quiet Policy}

"Keep Quiet."

Phrased used by POW and MIA Wives to Describe American Governmental Policy for POW and MIA Matters

In some form, all of the wives recall that, as part of the official notification process, military representatives also conveyed specific instructions or guiding principles intended to govern their conversations and actions. Although the remembered details differed somewhat from person to person, more than one of the wives mentioned receiving the following directives as part of the notification process:

- Keep quiet

- Don't talk about husband's status

- Don't tell anybody

- Never talk to the press or give interviews 
- Don't tell anyone about your circumstance

- Show any mail from your husband to the Navy

- Never intercede in any way on behalf of the prisoner (it might disturb what the government is doing) ${ }^{108}$

Although I could not locate an official government memorandum specifying that the above directives should be part of notification, one document does substantiate, in part at least, the guidance given to the women when notified of their husbands' fates. ${ }^{109}$ The document was a telegram sent to Sybil Stockdale on September 10, 1965, by Vice Admiral B. J. Semmes, Jr., Chief of naval Personnel. The telegram confirmed her husband's POW status but also stated the following: "You are again reminded to reveal only the name, rank, file number and date of birth of your husband to inquiries outside your immediate family."

Another piece of evidence that documents the government's directives to the wives is a one-page memo, Advice to Potential Prisoner of War Families (Appendix E), that Sybil Stockdale, in her role as the senior officer's wife, had prepared and sent to those she heard about who shared her situation. The paper articulates the directives she had received after being notified of her husband's status. Other than telegrams, this unofficial paper is the earliest documentation of the policies and procedures articulated

\footnotetext{
108 Later the guidance was amplified to specify "without State Department approval" and "independent actions could seriously damage negotiations being conducted in behalf of the prisoner by the State Department." Sybil Stockdale, unpublished data, private collection Vice Admiral B. J. Semmes, Jr., Chief of Naval Personnel, telegram dated September 10 and 11,1965, to 8 Sybil Stockdale. Sybil Stockdale, unpublished data, private collection Ibid.
} 


\section{Chapter Four}

by governmental and military authorities during the notification process. ${ }^{111}$ These policies and procedures were reflective of the State Department's policy of Quiet Diplomacy.

The Department of State's notion of Quiet Diplomacy referred to the strategy of using diplomatic pressure on the North Vietnamese through various channels to handle and/or address POW and MIA matters. The strategy — which the wives, over time, renamed the Keep Quiet policy and which Melvin Laird, President Nixon's Secretary of Defense, in an interview with me, called the "Do Nothing" policy-represented, from the wives perspective, an attempt to curtail their access to the media and an effort to keep them from acting, in any way, on their husbands' behalf.

The basis of the Quiet Diplomacy policy came, at least in part, from a conviction held by Robert McNamara, Secretary of Defense between 1961 and 1968, and Clark Clifford, Secretary of Defense, from 1968 to 1969. It was their conviction that any overt activity on the POW and MIA issue would, according to Richard Capen "annoy the North Vietnamese" to the point that they would "continue to torture and if not kill the men."

Furthermore, Richard Capen indicated other rationale for the policy. He said that officials in the Johnson administration were concerned it might jeopardize any resolution of the POW and MIA matter, or an ability to "end the war peacefully," or influence the "ability to negotiate a settlement in Paris." The overriding concern, Richard Capen said, was not to "embarrass the North Vietnamese," which "might back them into a corner [and] prolong the war." Therefore, "[the wives] were told to be quiet." Richard Capen,

${ }^{111}$ The government's position was published in a Fact Sheet issued by the National League of Families in January 1973. It stated: "The policy of the U.S. Government was to keep a low profile on the prisoner of war issue, and families throughout the U.S. had been encouraged not to discuss the problem in public." The Fact Sheet, republished due to the imminent return of the prisoners, was an updated copy from one the National League distributed in 1970. Phyllis Galanti, unpublished data, private collection. 
The Rise of the Reluctant Sorority

however, also conveyed what he and several governmental officials knew: if the "policy had continued there would have been a revolution and [the wives and families] couldn't of withstood the pressure of being quiet, and not knowing and feeling nothing was being done on behalf of these men."

Initially, however, several of the wives echoed the government's concern that they would do more harm to their husbands if they spoke out on POW and MIA issues. Sandy Dennison-known for her loyalty and willingness to take tough and thankless jobs as well as for being the wives letter-writer to governmental officials - remarked that the wives "were so afraid" since speaking out "would harm [the men] even more." Her personal fear was "that something could come back to harm my husband."

Sybil Stockdale remembered being warned, "Any information the press carried might be used against [the] men to torment them." Shirley Stark—who was thought of by the others as possessing a compassionate sixth sense because she just seemed always to know who required special care and attention—recalled, "You were walking on egg shells. ... I mean you dared not say anything to anybody because it might be . . they'd mistreat the men." One wife, Alice Stratton-considered as one of the intellects of the group and noted for her unwavering dedication to family and country—vividly remembered her neighbors coming to her door after seeing the official military black car come and leave from her home, but she never came out of the house. Finally a neighbor knocked on the door and asked Alice, "What's going on?" With tears streaming down her face she replied, "Oh, nothing." All she could remember was the warning that she could not say anything to anyone, a warning that, she said, came from "somebody in 


\section{Chapter Four}

Washington." Even though no one in Washington knew definitively what might happen, the concern - it seemed-was that "the men would get harmed in some way."

Some wives were admonished to keep quiet with the simple, "Don't tell anyone." Others recalled several specific guidelines, like those above, which were given either verbally or via a telegram. Though she did not receive specific guidelines, Jenny Connell Robertson remembered that military officials "gave you that indication" it was best to keep quiet, but she did not "recall anyone telling [her], 'You've got to be quiet.' . . . but it certainly was indicated." Overall, she felt, "They were in control."

Bonnie Singleton, on the other hand, remembered receiving a more specific directive. She was told she could only talk about her husband in terms of his "name, rank, date of birth and service number." The telegram that notified her of her husband's status also justified her compliance by stating, "This is the same information he must provide his possible captors."

When Phyllis Galanti was first told about the need to maintain silence, she also was given advice: "Don't even tell anybody he's been shot down. Say he's been extended." Phyllis told me that she thought, "That was a little hard to keep up and kind of ridiculous." Sandy Dennison, fearful of reprisals on her husband, admonished her parents to abide by the same rules she was told to follow: "Don't say anything. Don't do anything because this is what we were told to do." Eventually, however, as she seriously thought about the guidelines she concluded, "There was kind of this fear tactic" that kept her in line. She also thought: "There wasn't anything more that could hurt [the POWs] anymore than they already had been hurt." 
The Rise of the Reluctant Sorority

Other wives echoed Sandy's latter sentiments, which had been used as a coercive tactic by the government to maintain their silence. Marty Halyburton, for instance, who was only twenty-three when her husband was shot down, actually came to the same conclusion as Sandy. Marty was informed in February 1967, eighteen months after she was told her husband had been killed, that he was a prisoner in Hanoi. Immediately after the status change, she began to learn about the keep quiet policy via two other wives; Sybil Stockdale and Dot McDaniel. She said that she always "felt that keeping quiet was not going to help." With the change in her husband's status to POW, she was now asked to remain quiet about his new status. Several weeks later, however, the Navy informed her that they were considering a public announcement about his captivity to hold the North Vietnamese accountable for him. Shortly thereafter, the Navy went public, which was the lead story on NBC's national evening news, the Huntley-Brinkley Report.

The Navy's actions reinforced Marty Halyburton's immediate instincts about problems with the Quiet Diplomacy policy. Marty told me during our interview: "In something like this you fail to see it from other points of view ... We wanted our husbands back. When I look back ... I realize how I was looking at it from one perspective and it was as a POW wife."

So, for a number of years, the women publicly were well mannered and behaved ladies who did what the government told them to do. In part, this adherence to governmental instruction occurred because of the women's geographical isolation from each other. Also, some of the wives whose husband had been shot down between 1965 and 1968 remembered that they had, in fact, been prohibited from knowing the names of other military wives or family members in the same circumstance. This policy did not 


\section{Chapter Four}

appear to be adopted by all branches of the military services, nor was it clear at what level within the government this policy was made. What was clear, however, was that, from the wives' perspective, the administration of Lyndon Johnson treated the women and the whole POW and MIA matter with benign neglect. The women also believed that the way they were treated, and the POW and MIA matter more generally, changed with presidential administrations.

\section{Contrasts of Presidential Administrations}

"Dark, dark, dark night with the Johnson administration."

\section{Sybil Stockdale}

There is some debate about President Johnson's level of concern about the POW and MIA issue. In a Washington Post newspaper column, August 8, 1967, syndicated writer Jack Anderson, wrote:

Disturbing whispers have leaked out that the Johnson administration has not done all it could to arrange better treatment for American prisoners in enemy hands.

One high official complained to this column that prisoner problems have been given a low priority at the State Department. He quoted Secretary of State Rusk as telling aides that the captured Americans are not prisoners but hostages, that the Communists would demand a quid pro quo for treating them decently and that he had no intention of granting any concessions. ${ }^{112}$

Richard Capen, who was the Assistant Secretary of Defense in the subsequent administration, provided what might be considered a gracious reading on the Johnson administration's record on the POWs and MIAs. He noted, for instance, that President

\footnotetext{
112 Jack Anderson, "U.S. Accused of Prisoner Neglect," Washington Post, B11, August 8, 1967.
} 
The Rise of the Reluctant Sorority

Johnson was obsessed with trying to end the Vietnam quagmire and did not let himself get distracted by details such as the POW and MIA question. In addition, he noted that it was customary to address the POW question at the end of a war not during it. On the other hand, Capen also told me that military intelligence provided unambiguous evidence that the POWs in this situation were being tortured and that the North Vietnamese were not living up to international law in terms of their treatment of military prisoners. Thus, a case could be made for and against whether it was appropriate to judge President Johnson harshly on his approach to the POW and MIA issue.

From the wives' perspective, however, President Johnson and his administration were completely uninterested and/or unwilling to openly discuss the POW and MIA issue. What is quite clear is that, intentionally or unintentionally, the Johnson administration failed to effectively communicate with the wives, thereby irritating and disappointing many women like Marie Estocin, who was adamant in her conviction that Johnson was not pursuing "how the prisoners were being treated." Equally firm in her convictions, Shirley Stark proclaimed that when President Johnson was in power " the door was closed" to the wives. She quickly added, "He [President Johnson] had himself on his mind-not other people."

President Johnson's decision not to seek reelection in 1968 aroused additional anger and frustration among some of the wives. "I think really what made me most angry," Sherry Martin said, "was when President Johnson decided he wasn't going to run again. He just cut bait and ran. He abandoned us. Instead of solving it [the POW issue and the Vietnam War, itself], he cut and ran!" 
Chapter Four

In the private archives of Sybil Stockdale, I read the first letter she wrote to the POW wives that she had contact information for at the time. ${ }^{113}$ In it, Sybil wrote about her conversation with Governor Averell Harriman, Department of State's Ambassador-atLarge for POW matters, during a meeting she had with him in July 1966. She told the wives that even though she was not "a member of the political party of the present administration," she felt that their "husband's lives are in the hands of master statesmen who will do and are doing everything in their power to assure the safe return of the prisoners and bring the conflict to an early close." Governor Harriman told her that if at anytime she or any other wife "did not feel that he was doing his job," then "the best person to contact is Bobby Kennedy because Bobby Kennedy is constantly urging [him] on to greater effort."

Robert Kennedy, of course, was assassinated in June 1968, on the night of his victory in the California primary, and Richard Nixon, the Republican nominee, eventually became President. A number of the wives saw the election of President Nixon as a significant turning point on the POW and MIA issue. During their interviews, in fact, they spoke about the difference they experienced between the Johnson and Nixon administrations. Marty Halyburton, for example, declared unequivocally that "there was a move that [the wives] needed" and it came "when Johnson was out." The move that they needed, as she recalled, was the ability to openly talk about POW and MIA issues. Sandy Dennison said much the same thing: "It was kind of like a one-hundred-eighty degree turn from Johnson to Nixon," she told me. She felt the wives began to experience a

\footnotetext{
collection.

${ }^{13}$ Sybil Stockdale, to POW Wives, August 10, 1966. Sybil Stockdale, unpublished data, private
} 
The Rise of the Reluctant Sorority

freedom they had not known before - the freedom to talk about their situation and openly ask the public for support to bring pressure on Hanoi. Like many other wives, she possessed a newfound confidence that governmental officials in Washington DC "knew [the wives] were there." The stalwart Sybil Stockdale probably gave the most stark and vivid contrast between the Johnson and Nixon administrations. She said, "It was like night and day. Night--dark, dark, dark night with the Johnson administration. Bright sunny days in the Nixon administration."

What many of the wives did not appear to understand - even after three decades — was that the "bright sunny days" did not just happen with a change in administration. Rather, the climate changed because, as the insightful Sandy Dennison put it, "pressure had come to bear" on American government officials, both elected and appointed. Much of this pressure, of course, had been generated by the wives themselves who, by the start of the Nixon administration, had begun not only to form "the reluctant sorority" but also to transform the "sorority" into a potent organization with political force capable of influencing the Congress and, eventually, the President of the United States. The women, who were part of this forming group, organized and entered the political arena for a variety of reasons.

Personal Motivation for Involvement with the POW and MLA Issue

"To get our husbands home."

Sherry Martin

"Humane treatment."

Sybil Stockdale 


\section{Chapter Four}

During the interview process, some responses by the women triggered additional questions on my part. One of those additional questions dealt with their personal motivation for becoming active participants in the POW and MIA matter. The responses varied considerably but can be reduced to two general types of motives. Sherry Martin's response exemplifies one type of motive. When asked why she had become active, she responded, matter-of-factly: "To get our husbands home, of course." Sybil Stockdale, on the other hand, stated assertively that the immediate objective was not for President Nixon to bring the men home; rather, that the wives "were working to have them [their husbands] accorded humane treatment." As noted earlier, she knew the North Vietnamese were not abiding by the Geneva Convention Relative to the Treatment of Prisoners of War, which opened the door for additional maltreatment. Equally important, she was the sort of military wife who understood military traditions. One of these traditions, of course, was the tradition that Richard Capen had alluded to: The POW issue was normally resolved at the end rather than during a war. Consequently, during one of my interviews with Sybil, she stated that the servicemen held captive in North Vietnam "were all professionals and. . . they knew that it was dishonorable, of course, to come home before the end of the war."

Thus, the wives were motivated by somewhat different goals. Despite their different motives, however, the wives, collectively, managed to focus policymakers' attention on the POW and MIA issue and to effectively challenge the notion of Quiet Diplomacy or, in their words, the keep quiet policy. Doing this required transcending traditional ways of thinking and the learning of new roles. The learning process was, largely, not systematic or linear. Rather it was one of trial and error. And success was 
The Rise of the Reluctant Sorority certainly not immediate. The wives, in fact, had to quickly learn how to adapt and adjust when their initial strategies were less than successful, invent new approaches to get their message noticed in the policy arena, and, once they and their message did get noticed, find ways to confront and transcend governmental responses that were little more than procedural display.

Politicians, Appointees, and the American Public Attitude

What is the American Government Doing?

"Sybil aptly named it, 'The Washington Road Show.'"

Shirley Stark

"I found out that my husband was alive from the Today show."

Karen Butler

"We wanted to make this an issue in America."

Richard Capen

For the wives, information about their husbands was difficult to obtain from governmental agencies in Washington. They also had little to no information about any official plan or objective for resolving the POW and MIA issue. As a result, the wives began to question and complain to officials within the Department of Defense, Department of State, and to elected representatives.

Bonnie Singleton was convinced that what compelled the United States Air Force to finally respond to families was directly related to the growing number of aircraft shot down over North Vietnam. An ever-increasing number of families, as Bonnie recalled, "were wanting to know what the military was doing about this situation." Finally, in 1968, three years after Bonnie's husband was shot down, the Air Force Casualty Division 


\section{Chapter Four}

in San Antonio, Texas, arranged a meeting with families to discuss what the Air Force and non-military officials in Washington were doing and, as Bonnie told me, "why the policies were what they were."

There was a similar sort of pressure for information on the Navy side. Jenny Connell Robertson said, the wives "initially wanted the Navy to tell us what they knew about our husbands." She said, however, that the government-for whatever reason"wouldn't tell us what they knew about our husbands." Even after the North Vietnamese released a picture of her husband and proclaimed, "We have him," she could still not get answers to the most basic questions.

Over time, the women found other ways to get information. As the war progressed and the antiwar demonstrations became more intense, certain notable and controversial American citizens sympathetic to North Vietnam traveled to Hanoi and met with communist officials. Often these individuals returned with information on POWs and MIAs or letters from the POWs. It seemed odd, as even the wives felt; that they received information via antiwar leaders rather than their government. One of these wives was Sandy Dennison; she learned from information provided by Jane Fonda in 1971 that her husband had died in the prison camp. Even though this notification was not official, Sybil Stockdale advised Sandy to make the rounds on Capital Hill to inform lawmakers that she had obtained information about her husband's death from other sources other than the American government. For two days, Sybil "prepped" Sandy before she went to speak with elected officials on Capital Hill. However, when Sandy went to Capital Hill, she discovered the following: "Nobody would see me. Nobody wanted to talk to me. 
The Rise of the Reluctant Sorority

Nobody wanted to do anything." After this happened, Sybil advised Sandy, in Sandy's words, to go to the "press and tell them that my own government will not talk with me."

Eventually official Washington-undoubtedly prompted, at least in part, by media stories of the wives treatment by government officials - began to attend to the women and their concerns. From the wives' perspective, however, the response, for some time, was, highly formal and even perfunctory. The wives wanted information about their husbands and a commitment from government agencies to confront the North Vietnamese about their violations of international law as set for in the Geneva Convention. Both requests, of course, required reversing the government's official Quiet Diplomacy strategy, something the Johnson administration — and even the Nixon administration in its first months in power-was unwilling to do.

So, between 1965 and 1968, when the Johnson administration officially embraced Quiet Diplomacy as the operative method for dealing with the POW and MIA matter and met with the wives and other family members on an ad hoc basis, the substantive message was not much different from the message delivered during the official notification. Only the form had changed. In Karen Butler's words, the meetings "were 'dog and pony shows' to just make us feel important and assuage our frustration." Sybil Stockdale provided a similar characterization of the wives first meeting with President Johnson. She said that nothing of substance was discussed; rather it was a photo opportunity on the tarmac at North Island Naval Air Station, Coronado, California. It gave the appearance of concern but failed to convey genuine alarm or interest in the plight of the POWs or issues with the MIAs. 


\section{Chapter Four}

Sherry Martin agreed that, during the Johnson years, the wives were not "privy to anything," and Jenny Connell Robertson suggested that the women's growing activism and aggressively raising substantive questions was actively discouraged by government officials. Jenny also recalled that both military and civilian representatives treated the wives with condescension during the Johnson years. In her words, they were told, in effect: "If you guys would just be quiet, we will tell you what is going on and we'll give you all the information. You don't need to be searching any place else. We've got it and we'll give it to you if we've got it."

Jenny also remembered a very clear warning from American governmental officials that the North Vietnamese were "watching what [the wives] were doing." According to Jenny, the wives were also told about likely "Vietnamese spies" operating in the country, that the North Vietnamese had "dossiers" on the wives and their activities, and that North Vietnamese agents were "probably bugging [their] phones." None of this turned out to be accurate information, of course, and it was certainly possible - and maybe even likely - that those who were making these statements knew, at the time, that what they were saying probably was more fiction than fact. The subtext, however, was not subtle, according to Jenny. The message sent was that the situation required the women to remain silent and compliant!

The manner of addressing POW and MIA matter began to change, however, when President Nixon came to power. Even though the Nixon administration had made an official statement regarding the POWs and MIAs, high level officials within the Department of Defense, abandoned the ad hoc approach to "briefing" the women, and, instead, scheduled briefing sessions on a fairly regular basis in different geographical 
The Rise of the Reluctant Sorority

locations. What transpired during these now more frequent meetings was not radically different, however, at least not at first. Indeed, even though the intentions on the part of governmental officials in the Department of Defense were to be helpful, the wives referred to these periodic meetings cynically as "The Washington Road Show." Sybil Stockdale remembered the Nixon administration's first Washington Road Show, held in the spring of 1969 at Miramar Naval Air Station, San Diego, California, as an "incredibly volatile meeting."

Richard Capen was the person who had arranged the meeting that Sybil Stockdale, thirty-two years later, called volatile. At the outset of the Nixon administration, Richard Capen spoke to Melvin Laird, Nixon's Secretary of Defense, about the need to meet with the wives and other family members. Richard Capen was well aware that the wives had been told for five years to keep quiet. He also knew that the wives had begun to not only question that directive but also to actively challenge it. By the start of the Nixon administration, in fact, the women - who initially had refrained from publicly discussing their situations because they had been told such discussion would hurt their husbands - had become bolder in challenging the government's Quiet Diplomacy policy and the thinking that supported it. The wives and some family members of POWs and MIAs had also begun to function as an organization.

In an interview with me, Richard Capen indicated he understood all of this and his advice to Melvin Laird was based, in part, on a sense of duty to bring the wives "up to speed" regarding the Department of Defense's strategy in dealing with the POW and MIA issue. He also cited a more political reason for making the recommendation he made to Secretary Laid: He was aware of the wives' increased political activism and the likelihood 


\section{Chapter Four}

that the activism would continue and even increase if the government did not begin to treat them differently.

After Melvin Laird approved Capen's plan to brief the wives, Capen contacted Frank Sieverts, Assistant to the Secretary of State for Prisoner of War Affairs. He did this because, as noted earlier, the State Department, not the Department of Defense, was assigned responsibility for handling POW and MIA issues. This arrangement continued during the early months of the Nixon administration.

Capen recalled that Sieverts' initial response was that the contents of the Department of Defense's briefings needed to be cleared by someone at a higher level in the Department of State. Capen told Sieverts, "It's easier to get it cleared after it's been said. I want to do the right thing."

Richard Capen and Melvin Laird, by this point, were committed to, in Capen's words, "doing the right thing" with the wives and with the POW and MIA issue in general. The new leadership in the Department of Defense also had a mindset change; they began to see the wives as allies in their efforts on behalf of the POWs and MIAs. In an effort to do the right thing, Capen recalled he and his team went to over forty military bases throughout the country and talked with anyone wanting to meet with them. The number of family members that attended these meetings was a surprise, even to the family members, themselves, according to Capen. The meetings, in fact, were important in transforming the growing activism of a small nucleus of women whose husbands had been shot down between 1965 and 1968 into a much more extensive political movement. Until these meetings, in many cases, the women across the country who attended the meetings did not understand that were not alone in their ordeal. And 
both the indirect and direct messages of the meetings was new: The wives were now encouraged to talk with each other, and there was nothing about keeping quiet with others outside the group.

None of this was accidental. Rather, the briefing sessions represented a first step in a shift in policy on the POW and MIA question during the Nixon administration. Richard Capen indicted to me that it was the desire of Melvin Laird to initiate a POW and MIA policy change. One way this could happen, as he said, was to throw "fuel on the fire deliberately. ... We wanted to make this an issue in America."

Furthermore, this strategy was not entirely a clandestine one within the rest of the administration. In a memo from Brigadier General James D. Hughes, Military Assistant to the President, to President Richard Nixon, Hughes informed the President about the "last meeting of the Ad Hoc Interagency Coordinating Group on POW and MIA on Friday, 16 April [1969]." ${ }^{114}$ At this meeting, he told the President, there "were several developments which should be of interest to you." He reminded the President that earlier in the administration, joint Department of Defense, and Department of State briefing teams were dispatched around the country to meet with groups of POW and MIA families. The purpose, as he informed the President, was to bring them up-to-date on current events and to answer questions the wives and families might have at that time. These teams, he told the President, were successful in improving the morale of the families. (Some wives and families, undoubtedly, would challenge his conclusion.)

\footnotetext{
${ }^{114}$ Brigadier General James D. Hughes, Military Assistant to the President, to Richard Nixon, President of the United States, Washington, DC, Apr. 19, 1971; White House Central Files; ND 18-3 Prisoners; 1/1/71 [1972]; Nixon Presidential Materials; National Archives at College Park, College Park, MD.
} 


\section{Chapter Four}

In his memo, Hughes also informed the President of a new round of sessions that, he wrote, would "emphasize your interest in the families and in obtaining the early release of the prisoners and an accounting for all of the missing." He also informed the President that the teams have a more specific objective: "to explain the administration's position on the announcement of a firm troop withdrawal date and to reassure the families that [the administration's] withdrawal program does not abandon the prisoners." He also made the President aware of the teams' departure date, which was scheduled for May, and indicated that this date had been chosen "since a large number of families will be traveling until then to Geneva for a meeting of the International Red Cross, and to Budapest, Stockholm and other foreign capitols [sic]." ${ }^{115}$

Thus, there was a policy shift, of sorts, during the initial months of the new administration, and the President was kept informed that the shift was occurring. This shift was significant for wives and other family members who had not previously been privy to much information about their husbands and who had had little contact with each other. Of course, for some wives such as Sandy Dennison-who lived with the POW issue on a daily basis and who had kept herself informed about POW and MIA matters through direct and, often, indirect means - the briefings represented little that was new.

Twenty-eight years later, in fact, Sandy Dennison, recalled being frustrated by with what she and others referred to as "the Washington Road Show." She also was upset by the need to "start all over with the new administration." There was clearly exasperation in her voice, even twenty-eight years later, as she characterized her perspective at the time: "You'd have to hit the Hill again and then you'd have to go

${ }^{115}$ Ibid. 
The Rise of the Reluctant Sorority

through the Washington Road Show again. They'd come out and pat you on the back and you'd say, 'You don't have to pat me on the back.' 'I'm not going to cry. 'I'm not going to make you do anything.' 'I just want you to go back there and tell them what we want."'

Other members of the emerging activist organization were a bit more circumspect about the role that the government's efforts played in propelling them forward. Jenny Connell Robertson, for instance, remembered that an earlier Washington Road Show during the Johnson administration as the catalyst for the POW and MIA wives informal gatherings. She recalled Sybil saying, "Why don't we just get together and talk about this." The more formal organization that was eventually formed, as Jenny said, had its genesis in these "informal gathering ... to support each other and talk about what these government representatives had said."

It was during their discussions between 1965 and 1968, in fact, that the San Diego and Southern California wives became increasingly skeptical of the information they were receiving from Washington. The wives, as Sherry Martin noted, were not accustomed to questioning political leaders because, for one, they had never been in a position to do so. However, she added: "As time went on and we were being told nothing, we really felt they [the government officials] knew something and weren't telling us ... and we resented that." Thus, among the wives in San Diego, Lemoore, and the San Francisco Bay area, as well as in other military aviation concentrated areas with POW and MIA wives, there was a growing consensus by the end of the Johnson administration that governmental authorities "knew a lot more than they were telling us. . . they just were not passing the information on." Sherry, for instance, recalled that when the Secretary of the Navy, during the Johnson administration, spoke to the group of wives for 


\section{Chapter Four}

ninety minutes, she said that he said, "Absolutely nothing. Absolutely nothing!" She called it, "Big time talk."

Experiences like those that Sherry Martin described established a cognitive frame of mind for perceiving the efforts of the new administration. The frame, in effect, filtered out shifts - that, initially, at least, were quite subtle and not entirely definitive - in the government's message during the early months of the Nixon administration. ${ }^{116}$

Frustration, Doubts, and Cynicism

"I always felt we put them in a closet, a dark closet, and closed the door and nobody could open the door-that was the way I felt the government had done to the men."

\section{Shirley Stark}

Over a period of years, multiple factors brought about a growing disconcertion about the government's forthrightness about the POW and MIA situation among a group of women who, along with the parents of some of the captives, would become the nucleus of the POW and MIA movement. A reoccurring comment that many of the women recalled, both during the Johnson administration and during the early stages of the Nixon administration, had to do with assurances regarding the men held captive. The statement to Sybil Stockdale by Philip Heymann, Assistant to Ambassador Harriman, is characteristic of what most government officials working the POW and MIA issue were saying to the wives and other family members. As she recalled, he assured her that

\footnotetext{
${ }^{116}$ In my interview with Richard Capen, he acknowledged the difficulties that confronted the Secretary of Defense and his staff when they initiated the new round of briefings for wives and family members of POWs and MIAs. This was due, in part, he said to the fact that the families had been told to keep quiet for fear of endangering their husband's or son's lives or possibly negatively affecting the government's war settlement negotiations.
} 
The Rise of the Reluctant Sorority "everything possible was being done for the men's welfare and he had reason to believegood reason to believe - that the men were being well treated." Eventually, as Phyllis Galanti pointed out, the wives were no longer "swallowing every thing they [i.e., government officials] said hook, line, and sinker." In spite of their growing skepticism, however, most of the wives clung to often-repeated claim that the men were being well treated. "It was hope against hope, hope against hope, and hope against hope they could be right," Sybil Stockdale recalled during my interview with her. Sybil quickly added that, in time, the wives "finally found out they [the government officials] weren't right, over and over and over again." Sybil told me, "That's when you really become cynical."

It appears from the wives stories, in fact, that the more contact they had with governmental officials, the more they considered their statements perfunctory and, often, outright lies. Shirley Stark said it directly and unabashedly: "They lied!" Some governmental officials, as most the wives recalled, continually issued optimistic statements. Sybil, for instance, remembered a group of officials declaring, without any qualifications: "Don't worry, they'll be home by Christmas." This sort of statement made Sybil and many other wives feel government officials "were such liars - totalcomplete."

This judgment and the wives growing cynicism may see a bit harsh, but, in fact, from an historical perspective, the harsh judgments, and the wives' cynicism seem justifiable. As early as September 1966, in fact, when the wives and families were told that their men were being treated well by the North Vietnamese, there were clear indications government and military leadership were aware of the practice of torture by 


\section{Chapter Four}

the North Vietnamese on American prisoners. ${ }^{117}$ (See Appendix F for additional references regarding inhumane treatment of the prisoners after 1966.)

Furthermore, there was even evidence of torture that became public early on. Lieutenant Junior Grade (LTjg) Dieter Dengler, for instance, was shot down on February 1, 1966 - crash landing his plane in Laos. The following day, the communists' members of the Pathet Lao captured him. For six months, prior to his escape, LTjg Dengler endured torture, depravation, and human suffering. Among other things, he was "tied behind a water buffalo and dragged through the brush," and exposure to environmental elements. After his escape and an additional six-weeks of medical treatment, LTjg Dengler spoke at a news conference in San Diego, California, attended by fifty of the nations largest news agencies. He told those in attendance about his experiences as a prisoner. $^{118}$

For the women, government officials' patronizing method of communication could be as frustrating as the inaccurate message being communicated. With passion in her voice decades after the events occurred, Phyllis Galanti told me that the Department of State drove her "absolutely up the wall." She had the same reaction to "some Congressmen and Senators." She added: "You just felt like they were patting you on the head and telling you how brave you were, but that nothing was ever going to happen."

Karen Butler offered a somewhat more analytical characterization of government officials' treatment of the women. She felt that the officials she spoke with or those that came to address the wives were "just kind of paying attention to us and not telling us

\footnotetext{
117 "Ranger Pilot Tells Vietnam Escape Story," The North Islander (San Diego, CA), Friday, September 16, 1966. Sybil Stockdale, unpublished data, private collection. Ibid.
} 
The Rise of the Reluctant Sorority

really much of anything." Karen added: "It was more of a political reason of paying attention to us than really being informational."

Just as the wives were frustrated with government officials, the wives were equally frustrated with the antiwar activists, especially those who went to North Vietnam and visited the prisoners. Sherry Martin remembered that these antiwar activists inevitably returned to the United States to convey to the American people "a rosy picture" of the men held captive. "We all knew that was a bunch of bologna," Sherry told me.

A variety of events, some small and seemingly inconsequential and others that played out on the world stage, pushed the wives increasingly toward political activism despite their socialization to be the military-wife equivalent of Harriet Nelson. ${ }^{119}$ One of the seemingly inconsequential events (except, of course, the person who experienced it) involved Sybil Stockdale receiving a letter that the United States Navy had sent to her husband, Commander James B. Stockdale - even though he was in prison in Hanoi. Imagine Sybil's shock and disbelief when she opened the letter and read the following statement in the opening paragraph: "Congratulations, you have been selected for deep draft command." ${ }^{120}$ The letter convinced her, "if nothing else did, that it was hopeless not to just go to the top."

When Sybil and others such as Karen Butler began contacting high-ranking government officials, they took note of the fact that, among the governmental officials they were dealing with, Karen said, "there were factions that wanted to know what the

\footnotetext{
${ }^{119}$ In the ABC television series The Adventures of Ozzie and Harriet (1952-1966), Harriet Nelson played the character of a charming wife who adored and supported her husband while serving the family with absqlyte devotion.

Deep draft command is a professional selection to command a large amphibious ship, which is a prerequisite to commanding an aircraft carrier.
} 


\section{Chapter Four}

other was saying." This quest for inside information led Commander Boroughs to ask Sybil and Karen to secretly tape a meeting with Nixon administration and Department of Defense officials. The meeting occurred in May 1969 at Naval Air Station Miramar in San Diego, California, during one of the Washington Road Shows. Both were amused by their stints as sleuths; today they giggle and guffaw as they recount hiding listening devices in their girdles. But both also were seriously troubled-and, interestingly, continue to be seriously troubled - by the governmental infighting and failure to communicate that the request to "wear a wire" represented. Sybil recalled the primary Washington DC personalities in attendance were Richard Capen, Charlie Havens, and Frank Sieverts.

Sybil and Karen were set up with the microphone attached to their bra and a wire running down to the recording box at the top of their girdles and then to an on-off switch near their knee. All this paraphernalia was obscured by modest dress.

Sybil noted that the tapes they were "wearing" lasted no more than thirty minutes. Sybil told me that, after nearly an hour in the meeting, she raised her hand and said, "You know, we ladies have to have a restroom break." At that point, Sybil and Karen, as Sybil recalled, "whipped into the stalls" to turn the tapes over and return to the meeting.

Karen told me she thought the whole event was "hysterical." Laughing she said, "I remember being very cognizant of keeping my arm kind of protecting my body where the little box was so that somebody didn't bump into me and wonder why [I] had this metal box under [my] dress."

In fact, both women were amused by their stint as sleuths; today they giggle and guffaw as they recount hiding listening devices in their girdles. But both also were 
The Rise of the Reluctant Sorority

seriously troubled - and, interestingly, continue to be seriously troubled - by the governmental infighting they observed and government officials' apparent failure of to understand - much less be troubled-by what their request for the women to "wear a wire" represented.

Both Karen and Sybil never felt they were given any classified or secret information. Karen summed it up her view of the so-called Washington Road Showsand also the views of the other women I interviewed-as follows: "I never felt like there was significant information anyway. I never felt we really learned anything from anybody - it was more of a political reason of paying attention to us than really being information." Clearly, the government's "procedural display" approach to communication was a catalyst for the women's growing activism.

An international incident-and the events that transpired on the home front in its wake - also served as a catalyst for action. On January 23, 1968, North Korea seized the USS PUEBLO in what the United States said was international waters. The North Koreans disputed this claim and charged that the ship was engaged in ongoing spy activities. Along with the ship, eighty-two crewmembers were taken prisoner.

Rose Bucher, the wife of the Commanding Officer of the USS PUEBLO, did something immediately after the capture of the ship, that the wives of POWs and MIAs in North Vietnam had not done: She went public, criticized the United States government, and gathered public support for the captives' release. As Bonnie Singleton - who in the words of Sybil Stockdale was developing into a "real fire burner"—recalled, "My husband's plane had been down for three years when the Pueblo was taken captive, and within six months [actually eleven], the whole Pueblo crew was returned. So, I thought, if 


\section{Chapter Four}

I've been cooperative for all these years and stayed quiet and done what people said and kept all my questions to myself . . then maybe what she did was okay."

Bonnie Singleton was not the only POW wife who took note of what Joyce Bucher did and the eventual outcome of the USS PUEBLO incident. Among the informal POW and MIA wives groups scattered across the nation, Bucher's actions sparked a great deal of discussion and soul searching about keeping quiet and the wisdom of supporting the government's Quiet Diplomacy strategy.

Finally, the sheer amount of time and the perception that nothing was really happening was a significant factor in transforming the wives into political activists. Wives like Shirley Stark and Phyllis Galanti, for example, were incredibly frustrated by the debate at the Paris Peace Talks about the shape of the negotiation table. Decade's later, frustration continued to be evident. During my interview with her, Shirley Stark quipped, "I came so close to sending our dining room table . . . to Paris."

Other wives experienced similar sorts of frustration as months turned into years and their husbands were not home by Christmas as government officials had glibly promised. Sometimes privately and sometimes during discussion with the other wives or with trusted friends, the women began to arrive at a position that Phyllis Galanti articulated during my interview with her. She told me, "I think, for most of us, all of us military wives, the main frustration is that, if we were going to stay in this war, by-golly, do something to win it or end it; it just seemed to be going on forever. I mean the peace talks talking about the size and shape of the table for a couple of years. Bombing pauses-all those things were really awful for our morale." 
The Rise of the Reluctant Sorority

Thus, a variety of incidents and events, some that played out on the international and national stage, and some that were relatively inconsequential (except, of course, to the women experienced them), caused a growing number of wives to rethink very basic assumptions about the wisdom of their government and their own place in the scheme of things. However, although their numbers were growing, the group was still, most certainly, a minority even among those who qualified for membership in "the reluctant sorority." After all, none of the potential wives or family members had been socialized to enter the political arena, and, consequently, an extensive transformation process was required as a precursor to political activity on the part of the wives and families.

Socialization and social roles also were a factor for those who had begun to make the transformation. Sybil Stockdale and others, in fact, years later spoke of the significant challenge posed by the need to overcome the "male-female thing — the male thing —in Washington." This Washington DC attitude, as Sybil characterized it, assumed that females were members of the weaker sex that needed bureaucracies to "take care of you." To overcome the attitudes in Washington, the wives realized that they needed to end-run government officials. This meant taking their case directly to the American public. This task, however, turned out to be a bit more daunting than the wives originally realized. The American Public

"I felt like I had been dropped into the middle of another time."

\section{Karen Butler}

It was disconcerting to the wives, who were moving toward greater activism during the period from 1968 to 1969 , to discover that the American public knew very little about the POWs and MIAs in North Vietnam. Partly because of the public's 
Chapter Four

ignorance, the wives became more vocal and began talking to civic groups. Sandy

Dennison, for instance, recalled that she and others spoke at the Elk's and Lion's Clubs and that, afterwards, men would to come up and say, "We didn't even realize that there were prisoners over there." Sandy's bewilderment was captured in her own response, which she recounted to me decades later: "I thought, 'My God don't you read the newspaper or whatever?""

Karen Butler, who also began speaking to the same sorts of groups at about the same time, expressed a similar sentiment: "They didn't even know about Vietnam or didn't know there were POWs!" She added: "We had loved ones that were sitting over there in a prisoner camp for a long time already and people were totally oblivious to the fact that anything was really happening." She was astounded that educated people could function without basic knowledge of world events: "That was just incredible! It was mind-boggling!" she said. Then, in almost a prophetic voice, she crystallized what many of the wives also yearned to proclaim publicly: "People, it's important what's going on and what we're doing and the decisions that are being made."

Marie Estocin had similar experiences to the ones that Sandy Dennison and Karen Butler had had, and these experiences galvanized her commitment to make the "public more aware of what was going on." When cashing a check at a local bank in San Diego, California, a very large and significant Navy town, she was required to place her husband's duty station on the check. Accordingly, she wrote, "POW." Marie recalled, "The lady at the bank would look at me and say, 'What's a POW?"' Straightforwardly Marie said, "POW is a Prisoner of War!" The teller responded with, "A prisoner of war of what?" To Marie, this sort of response-which happened more than once-"seemed like 
'John Doe' wasn't involved." This lack of involvement frustrated her even more because the wives had been increasing their efforts to speak out and elevate public awareness of the POW and MIA issues.

Variations of Marie's story were told by the other POW and MIA wives whenever they gathered, and they repeated the stories to me when I interviewed them decades later. Mary Winn, for example, indicated that she, too, recognized that, in the early stages of the war, "People didn't even realize that we had prisoners of war in Southeast Asia." She heard comments like: "Prisoners?" "What prisoners?" "You mean Stillwater?" (Stillwater was a state prison in the area where Mary Winn lived at the time.) Mary told me that when she got this response she would frankly inform them, "Southeast Asia! They are held in Hanoi or camps in South Vietnam."

Mary also indicated that, at times, the public responses she encountered appeared to be fueled by something more than ignorance of the war and the POW and MIA issue. Mary recalled that, while collecting signatures at a bank to protest violations of the Geneva Convention Relative to the Treatment of Prisoners of War, a man asked her, "What's a nice looking woman like you doing out here with this?" She said, "Well, my husband is a prisoner of war." Drawing back, he said, "Your husband deserves what he got!" Sherry Martin also recalled war protestors who, on learning about the wives' husband in Hanoi, would respond cruelly by saying to the wives, "What in the world would we want them back for?"

Even groups that the women had reason to believe would be their allies were not always supportive in the early years. Sybil Stockdale recalled, that in the early days, "The National Navy League [a civilian organization dedicated to the education of Americans 


\section{Chapter Four}

and elected officials on Navy-Marine Corps issues and concerns] refused to pass a resolution supporting humane treatment for the Prisoners of War in 1967-68." Sybil explained this lack of support by noting that the POW and MIA issue "was not yet public ... There was no bandwagon."

Sherry Martin provided a less charitable interpretation of the situation. She stated, "America just didn't want to hear about" the POW and MIA issue. Rather, from Sherry's perspective, at least, Americans "were hoping the whole thing would go away without them having do a single thing."

Thus, the wives interpreted-and continue to interpret - the public's responses to their initial forays into the public arena somewhat differently. Despite their somewhat different interpretations, however, all agreed that the ignorance, indifference, and, at times, outright hostility they all had encountered represented a barrier every bit as large as the barriers they had encountered when dealing with Washington bureaucrats. The seemingly insurmountable barriers they faced, however, did not cause the women to retreat. Rather, they continued to wage their war to bring the POW and MIA issue into the political arena on two fronts: They continued to meet with and lobby government officials; they also continued their efforts to educate the public about the issue.

The latter campaign, as Alice Stratton would note decades later, "target[ed] the heartstrings of the American people." This sort of targeting meant that the wives conducted "many campaigns to get people involved in human-interest things," according to Alice. Eventually, as Alice Stratton later recalled, the POW and MIA issue "touched them and they responded." Alice speculated that the eventual success of their campaigns was due to "people feeling the unfairness of their [the prisoners'; mistreatment." Then 
The Rise of the Reluctant Sorority

she quickly articulated another hypothesis: "Maybe it is because we just kept the publicity up and hammering away and caught the attention." Alice also emphasized a point that is in no way ambiguous: "We sure didn't give up once we started. . . . They couldn't get rid of us."

Not surprisingly, the informal group's success with the public also gave them clout with politicians and government officials. In addition, the activities had an additional, largely unanticipated benefit: It brought the increasingly activists wives and families together through various informal networks, networks that also recruited new activists to the movement. These informal networks also served as the foundation for the more formal organization that would soon be created.. 
Chapter Five: Adapting to the Challenge—From Informal Relationships to a Formal Organization

"If I had to lose my husband, and he had to be shot down,

then I was fortunate in meeting these women

because we just grew up together-we really did."

Sandy Dennison

Establishing Support, Networking, and Developing an Agenda

"Everybody was so relieved to be talking

to someone else in the same circumstance."

Sybil Stockdale

After more than three decades, the women's voices still conveyed the sense of isolation and frustrations that they felt after learning their husbands were either a POW or MIA. The Keep Quiet policy had prompted uncertainty and isolation. They followed government official's directives, at first, and kept quiet because they were told that doing otherwise would bring suffering and hardship on their husbands.

None of this was easy. Jenny Connell Robertson, for instance, said to me that, after being told her husband was a POW, she felt "terribly isolated ... extremely isolated." Sandy Dennison remembered the "high level of frustration" that accompanied the rules and policies the wives had to follow. Marie Estocin said the lack of information and the inability to obtain answers to questions made the wives "totally frustrated ... [There was] lots of frustration." 
Adapting to the Challenge

Marie also told me about a small group of wives who began to reach out to each other in modest and tentative ways. The wives "were glued to the TV," she said, "calling each other because they were showing things on TV all the time." For the wives, any television clip that mentioned POW and MIA matters sparked discussion.

Slowly, sometimes haltingly, some of the women began to find each other; they gathered informally, at first, and provided each other tremendous personal support. The informal group also provided an opportunity to voice concerns and raise questions about the government's directives and policies, especially the government's Quiet Diplomacy approach to dealing with the POW and MIA issue. Soon the wives had renamed the Quiet Diplomacy approach "the Keep Quiet policy."

Over time, however, the women became increasingly less quiet and the concerns that they initially voiced to each other were translated into action. Their actions were modest, at first, but, in due course, the wives' voiced concerns became a full-fledged action agenda.

The incremental steps the wives took had three distinct organizational analogs. First, the informal group became the League of Wives of American Vietnam Prisoners of War (October 1967) which was still primarily an informal organization established to facilitate networking and the sharing of information and support among the wives. Second, the League of Wives, out of necessity, became the National League of Families of American Prisoners in Southeast Asia (June 20, 1969). And third, the organization underwent a name change when the League incorporated in Washington DC to National League of Families of American Prisoners and Missing in Southeast Asia (June 30, 1970). This section tells the group's organizational transformation story. 
Chapter Five

\section{A Support Group Forms}

Eventually, the wives discussions led to the formation of an informal group of POW and MIA wives in San Diego and Lemoore, California, who began to meet on a regular basis. When searching through Sybil Stockdale's personal archival files, in fact, I came across a piece a paper with the following written on it: "First Wives Meeting, October 6, 1966." In discussing this date with Sybil, it became clear that this October meeting was the first intentional gathering of a group of wives to discuss their situation. Sybil had learned from Patsy Crayton (another POW wife) that there was growing frustration about the government's Quiet Diplomacy policy, along with the desire for a more formal gathering of the wives to share information and discuss what was being disseminated from the government. Sybil had invited the group for lunch and, as she later recalled: "Everybody was so relieved to be talking to someone else in the same circumstance."

What was supposed to be a noon luncheon, lasting a couple of hours, went until after five in the evening. Sybil told me, "We just couldn't part." In a letter dated February 12,1967 , to Rene, a new POW wife in another location of the country, Sybil wrote the following about the wives group:

There are fourteen of us now here in this area and we get together about every three weeks for an exchange of information and social respite from family responsibilities. Among us we have about 30 children. Our next meeting will be a baby shower for a girl whose husband was shot down in November and who expects her fifth child in early March. The age span among the wives here goes from 42 (guess who she is) to 22 but the bond is close and overrides all the 
chronological differences. I was the only one here in my circumstance for several months and then was joined by two others ... one with four children and one with none who has a very responsible position with an Investment Company in San Diego. By September our number had risen to 10 and the girls asked me if I would plan a time for all who were interested to get together. Our first meeting was a luncheon here at my house and I must say that one had the feeling that a dam had burst as the questions and conversation tumbled one upon the other in a veritable race of communication. All stayed longer than she had intended and was reluctant to leave this newly found oasis of comfort and understanding from others who were almost literally "in the same boat." It certainly was not a morbid affair and I doubt that an unsuspecting caller would have guessed for a moment the purpose of our gathering. Only the hope and plan for another gathering soon finally allowed us to dissemble. ${ }^{121}$

\section{Ongoing Support}

After this first meeting, as Sybil Stockdale told me, the women "agreed that [they] would meet on a regular basis - as regular as squadron wives would always meet every month." This decision is hardly surprising. After all, as Sherry Martin told me, many of the wives "were already friends" when their husbands became prisoners or were classified as missing in action. In fact, the women who gathered in Sybil Stockdale's home on October 6, 1966, all lived on or near the military base and were part of a relatively closed and highly structured military community. Within this community, as Sybil comments suggest, wives' groups meetings a were well-established standard

${ }^{121}$ Sybil Stockdale, unpublished data, private collection. 


\section{Chapter Five}

operating procedure. Thus, it was natural and relatively easy for these women to turn to each other for assistance and support. Sherry noted, for example, that she "felt more comfortable talking about fears ... anxiety, worry ... with someone that has the same problem." She recalled that among the women "there was a comradely... . We could say anything to each other and we'd understand even if you went off and screamed in the bushes somewhere. We understood!"

Jenny Connell Robertson said much the same thing. She noted that it was often difficult "to be with other people because they didn't understand what you were going through." By contrast, there was a "comfort zone just being with POW wives. ... We became more like family."

This sentiment was also echoed in Sybil Stockdale's February 12, 1967, to Rene, cited above. She wrote: "Our meetings are not unlike the usual social times which wives have when their husbands are away. Most of them are held in each other's home as we feel a great need for privacy to freely discuss the problems which beset us all."

Family imagery was used frequently as the women attempted to characterize their coming together in the early years after their husbands were shot down. Karen Butler, for instance, recalled: "Maybe it was the traumatic aspect of it but I think it takes something fairly extraordinary to create the kind of bonding that occurred. We raised our children together in a man-less world. We did the holidays. It was a very strong, obviously female dominated, but I think it did provide extended family stability. It reached out to people and brought them together and helped them not to feel alone or like a freak if they were in an area that wasn't military-that nobody else in the town that was in that situation."

${ }^{122}$ Sybil Stockdale, unpublished data, private collection. 
Support for Those Who Lived Outside of San Diego

Not all military wives lived near a military installation and had a ready-made support group, because of their location, of course. Phyllis Galanti, for example, had to travel to be part of a group of women who shared her experience, but she indicated that she was willing to do this, despite the inconvenience. She told me: "When there's nobody else around who knows what you're going through, and you find somebody that you can converse with, it really helps."

Other women actually migrated to cities with large military bases where there was a concentration of POW and MIA wives. And even women who were already associated with a large military installation occasionally became part of the migration movement. For instance, a number of wives continued to live in base housing at Lemoore, California, for a time after their husbands had been shot down. However, the black military car entering the neighborhood to deliver unpleasant news to another wife was a painful reminder of their own black-car experience. After seeing the car drive down the street to another home too many times, some of the women decided to relocate to off-base housing in San Diego, California, where others had relocated.

The choice of San Diego was intentional. The Navy grapevine told of a vibrant and vital group of POW and MIA wives operating in San Diego. Today, we might call the group that had formed a "support group." Sandy Dennison, for instance, said the following about how the informal group functioned: "When one of you is down the other can be up and you just pick each other up. ... I can't tell you how many times we took care of each other's kids when one of them had to go to the hospital." And, in a light- 


\section{Chapter Five}

hearted voice that brimmed with laughter, Marie Estocin acknowledged: "It was a definite support group, but we didn't even know we were a support group at that time."

Similar groups formed in other cites, as well. Alice Stratton, for instance, told me that she and a group of wives in the San Francisco Bay area first met as a "social group" between 1967 and 1968. The social group was replaced by a support group, however, after a photograph of Alice's husband appeared in Life magazine in the infamous "bowing photograph" in which Alice's husband was pictured deferring to his North Vietnamese captors while in what looked like a near comatose state. Because of the international exposure of the photograph, the Navy permitted Alice to conduct "one interview" with the media. The interview and subsequent story appeared in several local and national newspapers along with her photograph. The result, she said, was that "other POW and MIA wives in the area called me up and ... we started to get together" on a regular basis. Women also began to "get together" in places like Virginia Beach, Virginia, Dallas, Texas, and Jacksonville, Florida, where there also were large concentrations of POW and MIA wives.

Chloe Moore talked about the twenty or more wives who lived on base at Naval Air Station Lemoore in Northern California. A number of wives stayed on base housing and as Chloe said there was an outpouring of support from other families, which she felt, had the attitude of "there by the grace of God go I." Chloe told me that during the holidays squadron personnel were very helpful if decorations needed put up or taken down. She said she never felt she was "being avoided or shrugged off because you were the one that had a husband that was gone." 
Not all POW and MIA wives lived in places where there were concentrations of POW and MIA wives, and most of these "outliers" were unable or unwilling to relocate to places that had women in similar situations. There was a concerted effort, however, to make these outliers a part of the network that was beginning to form. Some wives I interviewed, for instance, spoke of a resolute commitment to locate and communicate with other wives in remote geographical locations who were away from military installations. In spite of the official governmental directive to refrain from contacting other wives, the women made attempts to locate others via squadron "grapevines." In fact, each wife that I interviewed mentioned her ability to obtain names of other POW and MIA wives through this unofficial method.

The wives obtained names and made contact, as Sherry Martin told me, "to tell the other wives that were sitting in Kansas, Iowa, and other places . . . that there is somebody out there who cares, who is in the same situation, and trying to get as much information." Many of the wives I interviewed indicated that they wanted no one to be left out; some, however, told me that they had encountered a number of wives who wanted to remain alone and detached from the group, which was respected.

\section{From Support Group to Limited Political Activism}

A possible motive that these wives may have had for remaining detached was that the San Diego group was morphing from a support group into a group of political activists. Talk of politics and the venting of frustration with government officials and the government's keep quite policy, of course, had always been part of group meetings.

Indeed, some political talk even had occurred in the San Diego group's first official meeting in October 1966. The wives I interviewed who attended the first session 
Chapter Five

in San Diego, California, in fact, all agreed that the meeting not only provided personal support but also the need to communicate with government officials and begin asking them for information. Yet, in the early days, the women felt quite powerless. Decades later, Shirley Stark would characterize the group's thinking early on as follows: "Think about it? Coronado? This little place? What could we do here?"

Over the next several months, however, the women began to inch toward activism. Sherry Martin, for instance, spoke to me about how she, Sybil Stockdale and Shirley Stark, as early as 1967, would meet at Sybil's house nearly everyday to write letters, file correspondence, and talk. Even at this early stage, Sherry recalled that Sybil had begun to question comments made by Senators and was now teaching others to not only question the comments but hold officials accountable for such statements by writing letters to them. While reflecting back on these early days, Sherry Martin remembered that they "worked around [Sybil's] dining room table." Of Sybil, herself, Sherry stated, "She was really the instigator-a fantastic person."

Sybil's home was not the only San Diego area home where meetings were held. Marie Estocin, for instance, talked about meetings at Jenny Connell Robertson's home with Sybil Stockdale, Karen Butler, Jenny, and herself. Marie told me that they "would get together and say, 'What do we do?"' From their discussions, Marie said, that they "decided that writing letters was the first step." Clearly, this activity of airing their thoughts and writing letters became a precursor to the future, more formally organized campaign to hold elected officials accountable for public statements and to "pressure" the government to address the POW and MIA issue. 
Networking Across the Nation

The women's letter-writing campaigns mention above, however, was not only directed at public officials but internal to the group as well. Sherry Marin recalled that the wives' had another goal, which was "to keep [other wives and family members] abreast of what [they] were doing and what was going on." And Sybil Stockdale, with humor and unmistakable emphasis, proclaimed: "There is no communication system like a bunch of Navy wives!"

Thus, in their working sessions, in fact, Sybil Stockdale, Sherry Martin, and Shirley Stark — all from Coronado, California — developed contact files on other wives and family members of POWs and MIAs throughout the country. These files also proved useful in establishing the formal organization that eventually developed, as did the informal network that had begun to develop and informally coordinate activities. Alice Stratton of San Francisco Bay Area, who had become the communication conduit in Northern California, remembered Sybil Stockdale contacting her and telling her the San Diego group was "wanting to do something" beyond the support-group type meeting. Alice, who became the Northern California coordinator, was also working closely with two other wives MaeRose Evans and Julie Butler, remembered that the Bay Area groups of wives "were really ready to say, 'Yes!"' to this suggestion.

Sybil and her San Diego crew were not always the ones to initiate contact with those who became key players in the more formal organization that would eventually develop, however. Marty Halyburton, who was not living near a major military installation, was given Sybil Stockdale's telephone number by a Navy official after her husband's status had changed from KIA to POW. In February 1967, Marty contacted 


\section{Chapter Five}

Sybil and, at Sybil's encouragement, she, too, "began writing letters to those heads of state who maintained diplomatic relations with North Vietnam." Marty recalled that for the wives and families this letter writing campaign "was one of the early efforts" to get the attention of international leaders on the POW and MIA matter.

Mary Winn was another wife who initiated contact with Sybil and the San Diego group. Mary's husband was an Air Force, rather than a Navy, pilot. When he was shot down, she also was given Sybil Stockdale's name as a primary point of contact on POW and MIA matters. She remembered Sybil being characterized as "a woman in California knows a lot about this."

By April 1969 Mary had "tracked down this woman in California and telephoned her" and discovered that "she did know a lot about" the POW and MIA issues. A few months later, in August 1969 Mary Winn visited Sybil Stockdale at Summer Island in Branford, Connecticut. Sybil met Mary at the train station and they ended up sitting in Sybil's car where they talked for hours about POW and MIA matters. From these conversations, Mary learned Sybil was a seasoned veteran in the POW and MIA wives circuit and had an incredible amount of experience and knowledge about dealing with officials in Washington DC.

\section{Summary}

Thus, what began primarily as a support group and a forum to vent frustration and complain about government policy and government officials, slowly morphed into a political movement. To be sure, the morphing process was an incremental one. The first steps were relatively tentative: writing letters and visiting government and military officials. Eventually, however, the women would become more assertive and would 
Adapting to the Challenge

construct a formal organization out of their informal networks. It was this core group, as Jenny Connell Robertson recalled, "that developed into the League of Families." The League of Families, in turn, successfully challenged a diplomatic policy at the highest levels of government. Before all of this could happen, however, the wives had to learn to how to play a game they had never been taught growing up in the 1950s: the rough and tumble game of politics.

\section{Maintaining Appropriate Behavior with Governmental Officials}

"Be a lady and be yourself."

Mrs. Bailey, Mother of Sybil Stockdale

The wives consciously thought about how they should behave when dealing with government officials. No wife I interviewed recalled receiving advice on proper personal conduct when conducting business within governmental power structures, however. What Sybil Stockdale continued to bear in mind were the words of her mother, "Be a lady, and be yourself." Given the situations, she told me, it "was hard sometimes to do both at the same time." She knew she had to try however. She said: "I instinctively knew that we had to do it [interact with policymakers] in a dignified way. If we didn't, we weren't going to get anywhere because they'd write us off as a bunch of hysterical women. So I knew we had to be dignified about it."

This need to conduct herself in a dignified manner became an early entry into the diary Sybil started on September 11, 1965, two days after her husband was shot down. On Friday, September 17, she wrote, "I am in a rage of belligerence today. Why in hell 


\section{Chapter Five}

can't those slobs tell me whatever Stan Turner hinted he knew." ${ }^{123}$ Then she added the following comment:

The hell of it is I can't rage and scream as I would like to do because (1) It would work to my disadvantage as I would then be treated as an unstable neurotic (2) My observers would rejoice in announcing I am "cracking" at last-Thank heaven for [omitted] and [omitted] where I can pour out all my inner rage and know my confidence will be honoured $[\text { sic }]^{124}$

Despite the emphasis on remaining dignified, emotion was occasionally employed. The use of emotion, however, was always calculated. Mary Winn, for instance, told me: "Almost anything was fair, but we tried to be dignified—not hysterical-except if it seemed to serve a useful purpose. It was very controlled." She added: "The hysteria would have been very calculated because this was too serious."

One aspect of controlling emotions was controlling the content of public comments. Alice Stratton told me there was a standing policy developed by the emerging leadership group that governed the wives and family members personal conduct: They would not "deviate off into criticism of the government." Alice told me, "Sybil beat [this idea] into our heads and [the idea also was] what MaeRose Evans, a POW wife in San Francisco Bay area, talked to our group about."

The decision to control emotions and refrain from criticizing the government in public comments proved to be significant in gaining access to the highest levels of government. After President Nixon's inauguration in January 1969 Sybil Stockdale wrote 123

Admiral Stansfield Turner, a Naval Academy classmate of Sybil Stockdale's husband, held several prominent naval command positions during his career and served as President of the Naval War College, Newport, Rhode Island, 1972 to 1974 . From 1977 to 1981 he was the Director of the Central Intelligence Agency (CIA) during the Carter administration. 
a letter in which she requested an appointment to speak with President Nixon about POW and MIA matters. In staffing the request, Colonel James D. Hughes, Armed Forces Aide to the President, wrote to John D. Erlichman, Assistant to the President for Domestic Affairs, and commented on Sybil's "favorable character reference" from both Admiral Thomas H. Moorer, Chief of Naval Operations, and Mr. Frank Sieverts, Special Assistant for POW matters in the Department of State. Colonel Hughes also noted the following: "She has been described as an intelligent, stable and articulate woman."

Later the issue of emotional stability reappeared among White House staff when Melvin Laird, Secretary of Defense, sent a memorandum to President Nixon, in which he recommended to the President that a select group of POW and MIA wives and family members meet with him in the White House. Melvin Laird's memorandum initiated a flurry of discussion among the White House staff that reviewed Laird's recommendation and added their comments via official internal memorandum. In a memorandum drafted for Stephen Bull, Special Assistant to the President and Appointments Secretary, Colonel Hughes endorsed Laird's recommendation but added an important caveat: "I would not disagree with this provided that they were very carefully screened for emotional stability and judgment."

The meeting with President Nixon did eventually happen after nearly a year of discussion within the administration staff. In the time between Sybil's initial requests for a meeting with President Nixon in January 1969 until the meeting actually occurred in

${ }_{125}^{124}$ Sybil Stockdale, unpublished data, private collection.

Colonel James D. Hughes, Armed Forces Aide to the President, to John D. Erlichman, Assistant to the President for Domestic Affairs, Washington, DC, Jan. 30, 1969; White House Central Files ND 18-3/CO 165; Beginning; 12/31/69; Nixon Presidential Materials; National Archives at College Park, College Park, MD. Ibid. 


\section{Chapter Five}

December 1969 the women attempted to keep the POW and MIA issue alive by making many personal calls on a variety of government officials in Washington DC.

\section{Influencing the Governmental Power Structures}

"We came to know quickly that the men were not very high on Washington's list of priorities and it was up to us to make them seem very important."

$$
\text { Mary Winn }
$$

\section{Personal Contact Becomes an Imperative}

While discussing the various attempts to persuade elected and appointed officials to recognize their concerns about the status of the husbands, Sybil Stockdale articulated one of three "imperatives" that she had embraced during the wives' group's transformation from a support group to a potent political force. Two of these imperatives related to the establishment of rules and standard operating procedures of the formal organization that eventually would be established; these imperatives will be discussed in a later section of this historical account. The implementation of the third imperative, which related to contact with public officials, predated the establishment of the formal organization. Sybil characterized this third imperative as follows: "Nothing takes the place of a personal visit. Nothing! Nothing can be as strong as a personal visit. If you can, get in and see them face-to-face then that's ... the goal. You've got to talk to them face to face; until you do that you're not going to get anywhere. You're another layer . . you're a bother to them."

In fact, one of the ongoing activities of the wives was contacting officials in the Departments of State, Department of Defense, and members of Congress. One of the Congressmen the group contacted was the Honorable Melvin Laird (R-WI). The personal 
visits or letters written to his office paid dividends later on when Melvin Laird became President Nixon's Secretary of Defense. There will be more on this later.

Marie Estocin recalled: "We were just putting out a plea hoping that someone would start listening to us." Marie also echoed a common theme of the wives; they expected government officials "to be truthful. . . . to be honest. . . . to get information. ... . to let us know what was happening. . . to start making the general public more aware of what was going on."

Coming, Ready or Not

The women were not always given a warm welcome in the corridors of power, especially early on. Sandy Dennison put all of this in context: "What government official would want to see this wife who hasn't heard from her husband in four or five years descending on his or her office?". she asked rhetorically. She added that, despite the apparent discomfort, no governmental office would "treat us like a nonentity."

The women who traveled to Washington DC each had stories about the officials they met. Mary Winn's experience demonstrates the varied response between two nationally known political figures. She recalled, "Eugene McCarthy (D-MN) was invariably courteous and kind. He never failed to see me when I appeared at his office, whether or not I had an appointment. Hubert Humphrey (D-MN) had a different approach, he would call me unexpectedly, out of the blue, to ask how we were doing, and [ask] could he be of any help. His talks seemed more generally political than specifically related to the plight of our men." 


\section{Chapter Five}

\section{Another Reason for Contact}

Some wives such as Sherry Martin wrote letters, sent telegrams, or made phone calls, in part, to vent frustrations. Sherry, for instance, sent a telegram to the Secretary of the Navy stating her irritation with the way the government was handling a number of POW and MIA issues. The governmental response to this telegram was similar to responses received by the other wives. Sherry indicated she received "a very proforma type of letter." From her perspective, the response letter read as though the government official could now "put a check in that box" about communication with POW and MIA wives. Despite this proforma response, however, Sherry indicated she was glad she wrote this and similar sorts of letters that got similar responses. The communication with governmental officials, via telegrams or letters, was a way to vent, "It got it out of my system," she told me.

\section{A Shift in Opinion}

During my interview with him, Richard Capen noted, with considerable pride, that attitudes on the POW and MIA issue on Capital Hill were beginning to change in the early 1970s. As with any social change, there were undoubtedly a number of reasons for this shift, but, certainly, the continual contact by the POW and MIA wives would have to be among the reasons that, in Capen's words, the POW and MIA issue, "became popular . . the thing to do."

Congressional change in attitude was evident when Senator Bob Dole (R-KS) arranged a tribute to POWs in Constitutional Hall on May 1, 1970. The tribute was entitled: "Day of Appeal for International Justice for all American Prisoners of War and Servicemen Missing in Action in South East Asia." The tribute was designed to focus 
attention on POW and MIA matters and the detrimental influence of the husbands' imprisonment on their families. Seven days before the event, on April 23, 1970, Congress passed a Joint Resolution concerning POWs. Though this action had little real consequence and, therefore, could be seen as perfunctory, the act did demonstrate that Congress had, at least, become aware of the plight of the POWs and the families of the MIAs. The women considered this newfound awareness at least a modest victory.

What the wives were not aware of, however, was the "intense pressure" for the President or Vice President to attend the ceremony and officially greet the assembled group. ${ }^{127}$ In the end, neither the President nor the Vice President attended the Tribute. The decision not to attend suggests that, at the highest level of government, even an action that had little more than symbolic significance was believed to have high costs or high risks attached to it. Clearly, the wives had more work to do. Part of that work turned out to be the establishment and incorporation of a formal national organization, The National League of Families of American Prisoners and Missing in Action in Southeast Asia.

${ }^{127}$ General James D. Hughes, Armed Forces Aide to the President, to Jim Keogh, Chief of the White House research and writing staff, Washington, DC, Apr. 28, 1970; White House Central Files ND 18-3; Prisoner; [1969-1970]; Nixon Presidential Materials; National Archives at College Park, College Park, MD. 
Chapter Six: Developing an Organization for Exposure of the POW and MIA Issue

"The idea was to involve everyone emotionally so that they would put the whammy on the government to keep pressure on the North Vietnamese government, but also on our own government. We didn't say 'our own government' that was all kind of under the table and quiet. But boy it was there ... very much so."

Sybil Stockdale

The League of Wives of American Vietnam Prisoners of War becomes, The National League of Families of American Prisoners in Southeast Asia, which becomes, The National League of Families of American Prisoners and Missing in Southeast Asia "It is my personal opinion that they were particularly effective in being sure that the executive branch's attention remained fixed on the matter of their concern."

Al Haig, Jr.

Shirley Stark told me that the wives were "chipping away ... a little bit here and there" in terms of getting the government and the American public to attend to the POW and MIA issue. She also indicated, however, that progress was slow until the National League of Families of American Prisoners in Southeast Asia was formed in June 1969. (On June 30, 1970, the name was officially registered as the National League of Families of American Prisoners and Missing in Southeast Asia.)

The story of the formation of the national organization is a story an incremental evolution and improvisation. Decades later, in fact, Sybil Stockdale declared: "The whole thing was improvisation." Sybil, noted, however, that, throughout all the improvising, 
Developing an Organization for Exposure of the POW and MIA Issue there "was the commitment," that "was so personal that that is the difference. . . . It just wasn't some issue you wanted to accomplish. It was life and death. And, so you were willing to spend your money and do things that you wouldn't do normally."

The need for improvisation should be obvious from the contextual information that has already been presented. Phyllis Galanti summarized this contextual information as follows: She noted that the wives, via the National League, "became pretty powerful." She also noted, however, that the women's acquisition of power "was slow. . . We were neophytes," she told me. She also said as a group: "We didn't have any training." Phyllis, in fact, characterized the wives' formation of the National League as "a step into unknown territory."

Karen Butler told a similar story about the League's formation, albeit from a somewhat different perspective. Karen had participated in the informal wives' group that preceded the establishment of the National League, but, as she told me, she "never stayed intimately involved where it was my whole life." For a few years, Karen represented and spoke for the League of Wives and National League at the local level in San Diego. But, her involvement slowed down even more when she "made the decision that [she] needed to finish school and move forward in [her] life."

Despite the change in her level of involvement, however, Karen, told a similar story about the League's formation: "They were kind of learning as they were going [at first] ... The system [the wives had set up to communicate with government officials and each other] was not very well organized." She even wondered, somewhat humorously, whether "they had their act together" in the early years. 


\section{Chapter Six}

These early years, however, provided invaluable learning opportunities and set the stage for the more organized effort that was to follow. Gradually, sometimes haltingly, the group of wives that gathered around Sybil Stockdale's table in Coronado or some other home and began to reach out to other groups and individuals around the country. They also began to understand that their piecemeal approach that involved individuals contacting government officials either through correspondence or in person was having a limited impact. As noted before, but what seemed to materialize again in interviews, was Jenny Connell Robertson's recollection that the frustration and anger generated by the socalled Washington Road Show became an impetus for the women to realize that there was a need "to be more formal. ... We thought we needed to be a little more organized" to deal with governmental officials, Jenny said.

Karen Butler spoke about the idea for the formal organization and a greater level of wives activism was born around Sybil Stockdale's dining room table when the group was still relatively small and informal. Sybil, herself, described to me the founding of the League of Wives of American Vietnam Prisoners of War in 1967:

We wanted somebody from Washington to come to San Diego and tell us what was going on. We couldn't get anybody to come. We had been writing letters individually. Then we decided we would organize. I didn't know anything about the way you're supposed to organize a group. I looked the word 'league' up in the dictionary - that seemed to fit. We gave ourselves the League of Wives of American Vietnam Prisoners of War. We didn't say, "Missing in Action" because if they were missing they were either dead or prisoners of war. We rented a mailbox. We had stationary printed up and we elected officers. We instructed our 
Developing an Organization for Exposure of the POW and MIA Issue secretary to send a letter to Washington asking somebody from the Department of State to come and talk to us.

Sybil added: "In three weeks, Harriman's assistant was out here and talked to us. That, of course, showed us what organization would do. They responded when we asked them as a League to come. They didn't respond at all when we were individuals."

The lesson about the importance of having a formal organization was reinforced several years later when delegations of wives, on two separate occasions, traveled to Los Angeles to convince the writers and editors of Look magazine to run a story on their husbands' plight. The wives were rebuffed. Sandy Dennison recalled being told that their husbands "weren't news worthy enough." The comment shocked Sandy; three decades later, she still had emotion in her voice as she told me the magazine's reaction to their story pitch was "a terrible thing for a wife to hear." She described the magazine's rejection as "a low point" not only in her life but also in the lives of the others.

For Sybil Stockdale, however, the rebuff was a galvanizing moment. Sandy remembers Sybil's comment on their return trip to San Diego: "That's it," Sandy recalled Sybil saying. She noted that Look personnel were more interested in the informal organization the wives had formed than in their husbands' stories. Instantaneously, Sandy told me, Sybil "made the decision that she was going to form the National League of Families." Sybil, in other words decided, more or less instantaneously, to transform the League of American Wives of American Vietnam Prisoners of War, a more or less informal regional group that was little more than a Navy wives squadron group with a letterhead and a post office box, into a formal, national organization. Sybil, herself, 


\section{Chapter Six}

described the San Diego group's transformation into the National league, as follows: "We had become so by my magic wand of naming us as such."

Although Sybil made the decision to establish the national organization quickly, she had her concerns, which she knew about but not known by others. In May 1966 Sybil made a trip to Washington DC to meet with Commander Bob Boroughs in the Pentagon and Mr. Philip Heymann, one of Ambassador Averell Harriman's assistants in the Department of State. In a meeting with Commander Boroughs, he asked Sybil to consider assisting the office of Naval Intelligence with covert communications with her husband via her letters. She agreed to participate but decades later she told me that it was a very stressful experience and she feared making a mistake that would endanger her husband's life-if not result in him being killed.

Her concern, also, was that the covert communications with her husband might be discovered or compromised due to the forthcoming attention on the National League, in addition to her subsequent trips to Paris where she would confront North Vietnamese governmental officials. As the National League grew in prominence and activism, she recalled her feelings; "It was really very, very, very scary for me because I was deeply involved in the covert communication." Yet, as she told me, in time she was able to separate her work in the National League and her covert communications with her husband. She said, "I thought of them as quite separate."

Despite her fears and concerns, Sybil, with two of her youngest sons (the other two were in Prep School and College), left her home in Coronado, moved to Washington DC. There she pursued the goals of the National League, and in time, formally 
Developing an Organization for Exposure of the POW and MIA Issue established the National League of Families of American Prisoners and Missing in Southeast Asia in June 1970.

Retrospectively, Sandy remembers that Sybil's move to Washington and the establishment of a formal national organization "were kind of a turning point." She also acknowledged, however, that things might have changed "anyway because the administrations were changing and the war was going in a different way." My review of declassified government documents, however, suggests that, despite the significance of other two factors Sandy mentioned, the formation of the National League was essential for bringing the POW and MIA issue into the policy arena.

There will be more about the League's influence in a subsequent chapter. Before discussing this topic, however, more needs to be said about the formation of the League and its metamorphosis over time. As noted, the precursor of the National League was an ad hoc organization loosely based on a Navy aviation squadron wives' support group. While the structure of the ad hoc organization closely resembled the structure of a squadron wives' support group, the substance of what the group was actually quite different: This group became the voice of the POW and MIA wives and family members and quickly became the voice of the POW and MIA wives and family members with government officials and the general public. With increasing forcefulness, the group began to demand action from governmental officials and challenged the government's Quiet Diplomacy strategy, which has already been noted, the wives referred to as the "Keep Quiet" policy.

When this ad hoc group transformed itself into a national organization, the substantive agenda remained largely the same as the agenda pursued by the San Diego 


\section{Chapter Six}

squadron wives group. Although there were many changes, the League, in fact, never lost the wives' groups' focus on providing mutual support, gathering and disseminating information to wives and families, educating the American public, and demanding governmental responsibility for the well being of POWs and accountability of MIAs. The form of the organization, of necessity, changed rather dramatically, however.

The transformation of an informal group of squadron wives into an effective formal national organization, in fact, required making a number of fundamental decisions, adopting formal policies, and establishing basic standard operating procedures in a number of areas. These areas included making decisions about leadership, membership, funding, organizational structure, message, and strategies.

\section{Leadership}

"It's an era when women were not as deeply involved in leadership roles in business or government."

\section{Richard Capen}

Among the many questions an organization must resolve during its formation are questions about who will hold leadership positions and how those in leadership positions will be selected. Interestingly, the National League never formally addressed these questions until it was formally incorporated in the summer of 1970. At that time, a formal governance Board was established, along with procedures that were to be used by the Board to select the organization's National Director. Before formal incorporation, however, there was never any question about who the group's leader would be. Sybil Stockdale was the obvious--and unquestioned-choice. As Sherry Martin noted, Sybil 
Developing an Organization for Exposure of the POW and MIA Issue Stockdale the obvious leader "no matter what part of the country she was in.... From little ole Coronado around the dining room table to Washington."

Sybil Stockdale was the unquestioned leader of the group for a number of reasons. She had been the moving force behind the informal support group that had gathered around her dining room table in Coronado, California, and was also the leader of the League of Wives that had been established, mostly to facilitate information sharing among wives who did not live in Southern California and who, consequently, could not gather around Sybil's table. She also had transformed the League of Wives into the National League after the group had been rebuffed by Look magazine simply by, as she said, "waving her magic wand."

Even if the above factors had not existed, Sybil's personality, education, and presence undoubtedly would have made her the group's natural leader. One of the questions I posed during the interview dealt with where she and other influential members of the group derived their authority to lead a movement. Sybil responded immediately: "I never thought about it. Why would we not have authority? They were our husbands." Later she added: "Of course, we had authority. It was our business. For the government to have the authority, the sole authority - heaven help us—no way!"

In addition to her considerable intellectual and interpersonal skills and the personal leadership she had provided in the past, Sybil also was the obvious choice to lead the new organization because of the social role she played. When I asked Sherry the source-of-authority question, she quickly responded: "By rank." Although she indicated that she, personally, did not agree with a wife assuming the rank of her husband, she also noted that the tradition in the Navy was that junior wives, in that period, deferred to the 


\section{Chapter Six}

senior wives' guidance. In short, in the Navy, leadership is defined by position and this thinking applied to Navy wives as well as their husbands at the time-more so then than now. Thus, by virtue of her husband's rank —and also the longevity of his capture - Sybil would have been the obvious choice to serve as the group's leader even if she had not possessed the natural leadership proclivities and predilections alluded to earlier. It was these natural proclivities and predilections, however, which undoubtedly made Sybil an effective leader in the formal organization's formative period.

When the organization was incorporated in June 1970, Sybil decided to step aside as the organization's official leader for personal reasons. The years had taken their toll, and she needed a respite-and as she told me, quite candidly, "I hated Washington. It was awful." As noted, at that point, formal procedures were established to fill the National Director position. From an organizational standpoint, however, it is probably significant that the national organization, in its early years, did not have to contend with leadership struggles and find ways of managing the conflict that often accompanies power struggles within an emerging organization. It was certainly significant that someone with Sybil's experience, skill, and political acumen led the organization, during its early years. Her personal power will be readily demonstrated when government's response to Sybil and the organization she represented are discussed in the next chapter. 
Developing an Organization for Exposure of the POW and MIA Issue

\section{Membership}

"It was strictly a family organization."

\section{Sybil Stockdale}

It is impossible to determine precisely how many National League members there were at any given time due to the fact that records, files, and historical documents of the National League have been lost. ${ }^{128}$ The only estimate of the size of the membership I could find was in a memorandum from Colonel Hughes, Armed Forces Aide to the President, to John D. Erlichman, Assistant to the President for Domestic Affairs. ${ }^{129}$ The memo from Hughes estimated that the number of women who were members of the National League was fifty. During our discussions about this, Sybil Stockdale told me that she would estimate a more realistic membership numbered around sixty. It is interesting that in a 1970 television interview with Sybil, Barbara Walters introduced Sybil as "the leader of 3,000 women and members of American families whose men are believed to be Prisoners of War." ${ }^{130}$ To this date, neither Sybil, nor any of the other wives I interviewed know where Barbara Walters acquired this number. It may have been extrapolated from estimates of the number of POWs and MIA family members. Of course, most of these family members had not joined the National League.

\footnotetext{
${ }^{128}$ One wife I interviewed told me that the National League's historical files were "loaned" to a "researcher" and never returned. It is important to note that the some of wives I interviewed did not anticipate the continuation of the National League beyond the return of the prisoners in 1973. The women, however, understood the importance of the National League's documents for historical purposes, but at the time, when the prisoners returned, the cataloging and securing of documents was not a priority.

Colonel James D. Hughes, Armed Forces Aide to the President, to John D. Erlichman, Assistant to the President for Domestic Affairs, Washington, DC, Jan. 30, 1969; White House Central Files ND 18-3/CO 165; Beginning; 12/31/69; Nixon Presidential Materials; National Archives at College Park, College Parkk, MD.

Sybil Stockdale, interview by Barbara Walters, Today show, NBC, Jan. 20, 1970.
} 


\section{Chapter Six}

Two things are clear, however. First, the membership was, by design, quite small. Membership, in fact, was restricted, initially, to wives of POWs and MIAs, later, to mothers and fathers of POWs and MIAs, and eventually to other family members. ${ }^{131}$ The reasons for restricting membership to blood relatives of POWs and MIAs will be discussed below.

Second, not all POW and MIA wives and family members chose to become members of the organization. Marty Halyburton, for instance, spoke of attempting to contact wives or other family members and discovering that there were those "who didn't want to be a part of any of this." The League's response was to respect their decision. There was, in fact, a prevailing notion that other wives and family members should be respected and allowed to handle the situation in their own way. Graciously, Marty said, "We held no hard feelings. It was just their way of dealing with it." ${ }^{132}$

As suggested above, there were reasons for restricting membership in the organization. When Sybil Stockdale discussed the reasons why the League and National League became so influential, in fact, she cited restrictive membership as one of the most significant components of organization' success: "We never had anybody that was not related in some way to a POW or MIA. It was strictly a family organization. I think that was terribly key—very, very important." The intent was to ensure that formal members

\footnotetext{
${ }^{131}$ The decision to include mothers and fathers was one impetus for the organization's first name change from the League of Wives of American Vietnam Prisoners of War (October 1967) to the National League of Families of American Prisoners in Southeast Asia (June 1969). The second name did not include the term Missing in Action because Sybil, as she told me, the "MIAs were with us always but when it came time to expand the name it seemed only logical to include MIA" in the title. The League, in fact, underwent a third name change, which included "Missing" to signify the inclusion of MIAs and the presence of MIA wives and families. This occurred when the National League incorporated in June 1970.

Even with the limited membership, there was growth with each passing year; however, a minority of members were activists in the political and public arena. Richard Capen acknowledged this and told me that "there were a lot more members but there were a relative small number who were really leading this effort."
} 
Developing an Organization for Exposure of the POW and MIA Issue were committed to resolving the POW and MIA issue and also to ensure that the story the organization told was a compelling one, i.e., a highly personal one.

Mary Winn, in my interview with her some thirty years later, reinforced the logic for restricted membership when she stated that restricted membership was important in maintaining perceptions about "the legitimacy of the group." There could never be any doubt, Mary said, that "every person who was with the League had to be a genuine member."

As has already been noted, initially, membership was restricted to wives and this restriction was undoubtedly significant because it kept the organization small and closeknit during its formative years. The organization's size and its informal relationships allowed structures to emerge more or less naturally. It also permitted incremental, trial and error learning, something that was obviously important, given the wives' lack of experience in running large-scale organizations.

Eventually parents were permitted to join the group. Their entry, in fact, was part of the reason for the League's first name change: the League of Wives of American Vietnam Prisoners of War became the National League of Families of American Prisoners in Southeast Asia. ${ }^{133}$ Eventually, other family members were permitted to become part of the group. Sybil indicated that the League "wasn't designed that way, but it happened over time." During another conversation, Sybil said the following: "In time...it got to be cousins and so forth. And that was okay if you were a cousin, if you wanted to [help]."

${ }^{133}$ (See note 131.) 


\section{Chapter Six}

Sybil also indicated, however, that there was a line that would not be crossed in terms of membership: "We never had anybody that was not related in some way to a POW or MIA. It was strictly a family organization. I think that was terribly key-very, very important." Even when approached by an earnest young man from a neighboring community who wanted to help, Sybil would not yield on the issue of limiting membership to family members. Instead, Sybil invited the young man to her house in Coronado, and they jointly created a plan to form an affiliated organization: Concerned Citizens of America. This organization eventually became one of the many informally affiliated organizations that non-family members interested in working on the POW and MIA issue could join.

Thus, the decision to limit the League's membership - first to wives, then to wives and parents, and, finally, to any blood relative-was, in fact, significant for a number of reasons. First, as has already been noted, the membership restriction kept the League relatively small, and the League's small size, in turn, made it possible for leaders to continue to rely on somewhat informal and highly personal ways of doing business. Second, the family connection also meant that the organization had a built-in, compelling story to tell.

Third, the decision to restrict membership to family members also was instrumental in thwarting an attempt to take over the organization. In April 1970, Commander Boroughs informed Sybil Stockdale that a group of retired military officers wanted to gain control of the National League and permit public membership. Sybil knew that "the organization would lose what made it unique and gave it public appeal—only relatives of POWs or MIAs could be members." This argument proved to be convincing 
Developing an Organization for Exposure of the POW and MIA Issue to the National League membership, and the takeover attempt failed. To thwart any future takeover attempts, two months later when the National League incorporated, it inserted into its by-laws the following language: "The League shall be composed solely of family members of missing or captured Americans in Southeast Asia. Family members shall be given the broadest, possible interpretation and include, among other categories recognized by the Board of Directors, a blood or lawful relative of the American who is now or has been a prisoner or missing in Southeast Asia and his or her spouse."

\section{Financing}

"We paid our own bills."

\section{Sybil Stockdale}

At the outset of many of my interviews with Sybil Stockdale, she would share with me what she normally referred to as "key" and/or "imperative" ideas from our prior discussion. Some of these related to the formal and informal organizations that had been formed during the POW and MIA crisis. One "key," for instance, was a kind of dictum that guided action in both the informal squadron wives group and in the national organization: "Nothing takes the place of a personal visit." Another key that Sybil highlighted related to the membership issue that was just discussed: "We were strictly a family organization." A third imperative or key that Sybil highlighted in her conversations with me related to the topic of this section: the financing of the organization. The imperative was captured in one of Sybil's more pithy statements: "We paid our own bills!"

\footnotetext{
${ }^{134}$ Phyllis Galanti, unpublished data, private collection.
} 


\section{Chapter Six}

In Sybil's mind, when members of an organization depend on others to fund their work, they give their power and authority away. The dynamics of the organization change, and "a whole different complexity" is introduced into organizational life. Sybil stated: "The minute you start to collect money, you're in a whole different ballgame. They [i.e., financiers] feel that because they have contributed an amount of money that you owe them something."

Thus, as Sherry Martin, decades later, remembered: "Anything of any expense at all ... we absorbed it." This meant that the women absorbed costs personally rather than organizationally. The National League did not even have a treasurer, and no dues were ever collected. None of this was easy because the women were not wealthy. Sherry, for instance, recalled how the wives really did not have a lot of money to cover expenses, even phone calls, which made the nickel stamp a much better use of personal resources. Like many of the women, she juggled personal finances to cover cost of mailings, phone bills, or trips. Similarly, Mary Winn recalled, "The game I played with money was not to go into debt during any single month." She too recalled that the "government never supplied any funds, nor did I or we ask for any money."

As is often the case in organizational studies, the fiscal reality was not quite as clear-cut as the rhetoric about financing. While it is certainly the case that the women did not solicit contributions or depend on substantial funding from others to do their work, it is also the case that they were offered and when appropriate accepted specific types of support. For instance, Sybil noted, "We were given free office spaces in the YMCA in San Diego." She also told me, "When I went to Paris [with the hope of confronting the North Vietnamese about POW treatment], I would buy the ticket, but Reader's Digest 
Developing an Organization for Exposure of the POW and MIA Issue reimbursed me." And, in the later years, after the group had been more or less embraced by the government, Sybil indicated that she "would travel back and forth [between Washington and California] on Mrs. Nixon's plane" if it was already traveling between cities. Other government flights-mostly those under the auspices of the Department of Defense-were available (space permitting, of course) to leaders within the organization in the latter years once the government and the National League had become apparent (though still somewhat suspicious and indirect) allies.

Even before the thaw had occurred, wives were able to take advantage of a Department of Defense policy that permitted spouses and their children to travel on military planes on a space-available basis. At least some of the wives took advantage of this privilege. This privilege was not immediately available, due to a bureaucratic technicality. The military policy was that family members had to fly with their husbands. The wives finally convinced the bureaucrats that their POW or MIA husbands could not possible accompany them and the policy was officially modified on May 2, 1968. As of July 18,1968 , the wives were permitted to travel on military flights without being accompanied by their husbands.

There was also substantial support from private businessman Ross Perot. More specifics of the support provided by Perot and others are discussed in a later section.

What is important here, however, is a distinction that, in the minds of women, at least, was quite clear: There was a difference between soliciting funds and accepting donations (or taking an advantage of scheduled military flights, a privilege accorded to all military wives). Soliciting funds was not an acceptable strategy, according to National 


\section{Chapter Six}

League thinking; it was appropriate to accept donations, however, if it was clear that the donations came with no strings attached.

On at least one occasion, according to Sybil, this clear distinction became a bit blurred. Commander Boroughs informed Sybil that the Fairchild-Hiller Corporation wanted to present her with a $\$ 1,000.00$ check but the stipulation was that she would personally need to pick up the check at their office in Washington DC. Sybil did not see the need for this personal appearance since, for one, she felt she was going to be examined by the corporate hierarchy as whether or not she was "emotionally stable." In addition, she was concerned about creating the impression that National League members or officials actively solicited funds to support the organization.

In the end, however, despite her misgivings, Sybil showed up at Fairchild-Hiller Corporate office in Washington DC to accept the check. Less than enthusiastic about doing this, however, because, in her mind, the public appearance at the company's office muddied a distinction that, to her and the others was quite clear: the group did not solicit funds; it only accepted donations.

To some, the distinction between soliciting funds and accepting donations may seem to be a bit arcane and academic, or even inconsequential, especially when viewed from the perspective of the sort of pragmatic decision just described. Anyone who has witnessed an organization in which the organization's substantive mission got ignored because of the need for ongoing intensive fund raising efforts, however, will understand that the conceptual distinction was almost certainly important in terms of keeping the National League "on message" and not distracted by organizational maintenance matters. 
Developing an Organization for Exposure of the POW and MIA Issue

The commitment to not solicit funds, in other words, was another manifestation of a commitment to keep things simple and focused on the task to be accomplished.

\section{Organization}

"The unity and strength of the League was more effective than individual efforts — and you could see this. You could see how

the organization was going to be a benefit."

Mary Winn

"As time went on, our organization really became refined in response to specific events." Sybil Stockdale

As noted, the National League of Families emerged out of a more-or-less informal group of Navy wives that, organizationally, was modeled after the traditional structure of wives groups within naval aviation squadrons-with some likeness in other branches of service. Of course, a national organization required the invention of somewhat different structures, and, over time, these different structures began to be put in place.

When discussing the organizational structure of the National League decades later, the majority of the women recalled that what was created structurally was primarily to facilitate effective and efficient communication. Bonnie Singleton, for example, noted that a major benefit of a national organization was the ability to "communicate with one another and pass on information and share ideas."

Sybil Stockdale, the prime mover in setting up the national organization, also knew that communication and dissemination of information was the key to a successful campaign to influence public officials. To facilitate communication, Sybil, established a National Coordinator and Area Coordinators located across the country. In time, she and 
Chapter Six

a couple of others, decided to align the area coordinator structure with the state structure, so that there was an area coordinator for each state rather than a coordinator for a region that might encompass several states. This was done because Sybil and Mary Winn had concluded that, as Mary put it, "people would be more responsive" if they could identify and represent their state - thereby providing a greater sense of ownership in the organization.

The establishment of the area coordinator structure and the communication patterns that flowed through these structures was, of course, facilitated by the fact that most of the key actors knew each other previously and had, in fact, already been communicating through informal networks before the formal organization was founded. Bonnie Singleton, for example, remembered that she already knew Sybil quite well when Sybil called Bonnie in Texas to inform her about the new national organization and request that she become the area coordinator for her region of the country.

Decades later, Sybil described to me the League's and National League's Area Coordinator's role and responsibilities:

The Area Coordinators - their job was to pass on the information ... to disseminate the information. For example, suppose we wanted to do our "Telegraph-In" [an effort to inundate President Nixon with telegrams urging him to promote humane treatment of POWs]. I would contact the area coordinator and tell them what we were going to do and they would go ahead and contact all their people. That was the way we disseminated the information.

I felt that it was important for me to speak out on the subject and that [also] was one of the responsibilities of the area coordinators. Since the purpose 
Developing an Organization for Exposure of the POW and MIA Issue was communication they, of course, would call television stations and give speeches. The more people we could get doing that the better.

Area coordinators and those who worked at the national level not only focused on communicating with those outside of the National organization but there was also a strong emphasis on within-organization communication. As a member of the National League's Board, Marty Halyburton knew it was important to keep in contact with the wives throughout the country. She told me, "We kept our 'troops' at home informed of the National League." To speed communication internally, the organization was designed in such a way that communication flowed in two directions, from the top down and from the bottom up. This meant that a new wife or family member to the organization, without any position in the League or National League, for any reason, could communicate up to the National level without any impediment just as the National leadership and area coordinators could send out their communiqués to the membership.

The organization's communication system was highly effective. Alice Stratton used a metaphor to make this point. She noted that, on various occasions, North Vietnamese officials gave letters written by prisoners to antiwar activists, who would bring them back to America. "When letters would come out and they'd hit the," Alice told me, "they were just like the jungle drums. ... We'd start hearing, 'They're coming, they're coming, they're coming.'" Alice also indicated that the jungle drums were equally effective when those at the national level needed to transmit information or promote a coordinated campaign. In short, during my conversations with her, Alice credited the network of communication that was formalized by the establishment of a national organization with both with keeping the wives and, eventually, other family members 
Chapter Six

knowledgeable and "tight" as well as allowing national leaders to quickly mobilize members of the group to influence national policy.

Thus, the establishment of a national organization cemented and broadened the tightly knit system of communication that had operated on a more piecemeal and ad hoc basis previously. In other respects, however, the national organization tended to be what organizational theorists refer to as a loosely coupled system. Mary Winn, for example, who served as one of the initial regional area coordinators and, later, as the coordinator for the state of Minnesota when area coordinators were designated for each of the states, did not recall any rigid mandates or standard operating procedures being imposed on those in the field. She noted, for instance, that there was no expectation coming from the national level about when or how often membership meetings should be held in a region or state. This and other matters were decided locally and were handled differently in different regions and states.

The absence of a highly bureaucratic organizational structure, however, should not be seen as signaling a lack of leadership at the national level. Rather, the loosely coupled structure permitted a type of leadership that encouraged grassroots initiative and trusted members' abilities and insights. Its form of leadership eschewed micromanaging or exercising excessive oversight, neither of which was needed given the members' shared and highly focused purpose.

Instead of meddling or spending their limited energy trying to control what happening locally, leaders at the national level organized campaigns to influence national policymakers and informed the public about the POW and MIA issue through the national media. Because of the small, close-knit nature of the organization, however, 
Developing an Organization for Exposure of the POW and MIA Issue those in Washington DC were aware of local initiatives and the strengths of those who worked at the local level. When appropriate, they tapped the special skills and talents of local actors to help the group, as a whole.

For instance, Sybil Stockdale asked Mary Winn, who worked at the local level as an area coordinator, to address the Air Force's policy that prohibited the disclosure of POW and MIA wives or family members to other women or family members in the same situation. The Air Force also had refused to provide this sort of contact information to the National League. Since Mary's husband was in the Air Force, Mary told me that Sybil suggested that she "make an appointment to see General John Ryan, then Air Force General Chief of Staff, and ask him to amend the Air Force policy to make it possible for effected family members to meet one another and derive whatever comfort could be gained from knowing others in our circumstances."

Mary requested such a meeting during which she asked General Ryan to clarify the Air Force's policy with respect to POW and MIA wives and family members. Mary told me that she said to him, "I cannot believe it is the intention of the Air Force to deny the family members the comfort of at least knowing one another in the same set of circumstances." General Ryan told her it was "not the intention of the Air Force" to do this, but he also expressed his concern that "not everyone will wish to" participate. Therefore, he asked her, "How do we preserve their privacy?" Mary and the General worked out a way to accommodate the Air Force's privacy concerns while still giving the League access to those wives and family members who indicated they wanted to be contacted. Essentially, the General agreed that the Air Force would contact relatives and ask whether they could release their names to the National League. Mary recalled that 


\section{Chapter Six}

most Air Force wives and relatives "decided they would like to know others and we soon had quite a group."

Those unfamiliar with military culture may not appreciate how unusual it was for someone of General Ryan's rank to agree to meet with a military wife, must less to attempt to accommodate her request; it was equally unusual, especially at that point in time, for a military wife to even request such a meeting. How much the existence of a national organization factored into General Ryan and Mary Winn's decisions cannot be determined. But it seems obvious that General Ryan would have been aware that the request came not just from an Air Force wife or even from a wife whose husband was a Vietnam prisoner; rather, as the letterhead on Mary's letter requesting a meeting made clear, the request came from an official of a national organization. And Mary, herself, most certainly understood that she was making the request, in part, in her national organization role.

Other wives have spoken of the significance of these sorts of factors. Jenny Connell Robertson, for instance, indicated that the establishment of the National League eliminated many of obstacles that the wives first had encountered in the years from 1965 to 1969. She also indicated that the organizational structure of the National League provided a sense of being "united . . quite strong," and a greater sense of confidence that their actions "were having some effect." Similarly, Sandy Dennison noted that the National League was a reminder to governmental officials, "We're here, and if you don't [address POW and MIA issues] then we're going to do this and this."

Both Sherry Martin and Shirley Stark stated that the move to Washington DC and the establishment of the National League was crucial for the group's effectiveness. 
Developing an Organization for Exposure of the POW and MIA Issue Sherry noted, for instance, that San Diego, California, was too far away from the "center [and] where things were happening." And Shirley said: "So much comes out of Washington. They could call a news conference ... put out information and hopefully some TV stations or networks, newspapers would pick up the stuff ... and we could make people aware of what was going on more."

At a more mundane- but no less important—level, the national organization provided support for activities that were initiated and carried out locally. The national organization also established policies — albeit a limited number-to manage emerging problems and protect the integrity of the organization as a whole. At least some of these policies represent a careful balancing act: they reflected a sensitivity to the importance of - and the need to not unduly inhibit or restrict—grassroots initiative and innovation, on the one hand, and a commitment to protecting and maintaining the organization's principles and mission, on the other hand.

An example was one of the national organization's by-laws approved in June 1970. This particular by-law was a response to a phenomenon that will be discussed in more detail below in the section on the strategies employed by the League. Simply stated, a number of local organizations began to affiliate with other organizations, some of which were aligned with anti-war activists - though the National League did not endorse this manner of activism or political persuasion - it would, however, attempt to use them to maintain their momentum and keep their options open. The particular by-law in question permitted such activity at the local level but, also, attempted to insulate the national organization. It stated: "Members may participate, facilitate and develop activities with other private or public groups or organizations and governmental agencies 


\section{Chapter Six}

which are working to achieve the same humanitarian objectives as the League, but the League's endorsement of these activities or organizations shall be subject to the approval of the Board of Directors."

Simply establishing a national organization, of course, is no guarantee that the organization will have the sort of impact that the National League, in fact, had. Consequently, the League's success story is much more complex and considerably more nuanced. Undoubtedly, a significant factor in the success story is the fact that legal incorporation came later rather than sooner. The process to legally incorporate the National League as a nonprofit organization, in fact, was not begun until late May 1970 when twenty representatives from the National League met in Washington DC to begin the process to incorporate the National League as a nonprofit organization. Even then, as noted in the discussion of membership issues, legal incorporation was, in part, a defensive move prompted by the takeover attempt by a group of retired military officers, whose intentions were to open National League membership to the public. It also, however, came from a small group of concerned citizens in and out of government looking out for the National League. Legal incorporation finally happened on June 30, 1970 - along with yet another name change designed to highlight the organization's concern with those men who were missing in action. Thus, as previously mentioned, the official name went from the National League of Families of American Prisoners in Southeast Asia to the National League of Families of American Prisoners and Missing in Southeast Asia. On that date, the newly incorporated organization also opened its new office at 1 Constitutional Avenue in Washington DC.

\footnotetext{
${ }^{135}$ Phyllis Galanti, unpublished data, private collection.
} 
Developing an Organization for Exposure of the POW and MIA Issue

The cavalier approach to legal incorporation, until it became a strategy to respond to a particular problem, was significant because it meant that the organization's structure could more-or-less evolve - and build on informal standard operating ways of doing business that had already been established - in a relatively unhurried and natural way. This evolutionary process, along with the small size of the organization that was a product of the decision to restrict membership to family members, also meant that the National League was an organization held together primarily by relationships rather than by bureaucratic rules and regulations. The relational nature of the organization, in turn, had implications for the morale and level of commitment of the organization's members. Incorporation, of course, did add a level of formality to the organization that had not been present before. When Sybil decided to step aside as the National Coordinator, which she had "elected herself" to when the organization was in its formative years, her personal choice for her successor - and the first National Coordinator of the legally incorporated entity — was Iris Powers, the mother of a MIA soldier. The Board, however, as Sybil told me decades later, "felt we ought to have a wife." Thus, Iris became the Assistant Coordinator and Joann Vincent, an Air Force wife, became the first National Coordinator.

Incorporation also required that certain aspects of the organization had to be written down and made explicit rather than implicit. The Articles of Incorporation and By-Laws of the National League, for example, clearly speak to the issue of the longevity of their organization: "The Corporation shall exist for so long as its purpose remains 


\section{Chapter Six}

unfulfilled - as long as men are missing or captured in Southeast Asia." ${ }^{136}$ The Articles also articulated an eight goals or purposes of the organization:

- Securing human treatment in accordance with the requirements of the 1949 Geneva Convention Relative to the Treatment of Prisoners of War and as recognized by general humanitarian standards for those Americans captured in Southeast Asia;

- By obtaining identification of all those who are being held captive by the North Vietnamese, the Viet Cong, the Pathet Lao and other hostile forces;

- By obtaining proper medical care for all;

- By making the American people and the people of the world aware of the unconscionable plight of those Americans who are missing or captured in Southeast Asia and their families;

- By facilitating and promoting communication of information of mutual interest among all families of missing and captured Americans;

- By facilitating and developing activities with other private or public groups or organizations and governmental agencies which are working to achieve the same humanitarian objectives;

- By maintaining and supporting the morale of all captured and missing Americans and their families; and above all

- By obtaining at the earliest possible time the release of and a complete accounting for all captured or missing Americans in Southeast Asia. ${ }^{137}$

\footnotetext{
${ }_{137}^{136}$ Phyllis Galanti, unpublished data, private collection. Ibid.
} 
Developing an Organization for Exposure of the POW and MIA Issue

The above purposes were hardly new, however. By the time they were codified as part of the Articles of Incorporation, they had already been lived on a day-to-day basis by the organization's members. And by the time organizational procedures had to be formally established, they had been tested and modified many times over. The legal organization created in the spring of 1970 , in short, for the most part mirrored a natural organization that had started around and evolved from a gathering around a dining room table in Coronado, California.

\author{
Message \\ "We kept it simple." \\ Alice Stratton \\ "To let people know that things were not all rosy." \\ Phyllis Galanti
}

By the time Sybil Stockdale appeared on the January 20, 1970, episode of the Today show, the wives who led the national organization had honed a relatively succinct message for what interviewer Barbara Walters characterized as the wives' "campaign." Essentially the message focused attention on the plight of the prisoners, a plight that most Americans were still unaware of when a formal national organization was established. There was also a corollary idea that was part of the carefully honed message: the need for the prisoners to be afforded humane treatment and, more specifically, the need for the North Vietnamese to adhere to the Geneva Convention endorsed and required ways of treating POWs.

In retrospect, the simple and straightforward message may appear to be obvious and articulating it and getting group members behind it might appear to have been an 


\section{Chapter Six}

easy task. In fact, as noted previously, initially there was disagreement about what goals should be pursued.

This message, which had also been honed over the years, came through loud and clear during Sybil's Today show interview. For instance, twice during the interview, Sybil referred to the "desperate plight of the prisoners," and, at one point, she told Barbara Walters, "We want to secure the protection of the Geneva Convention Relative to the treatment of Prisoners of War for the men."

Sybil also identified the target audiences for the group's message during the interview: Congress, the American public, the citizens of the world, and the North Vietnamese government itself. She predicted that, because of her organization, members of Congress "will become much more personally aware of how desperate the plight of all the men is." She added, "They will try to search harder for things personally they can do to help the men and to make their constituents aware of the plight of the men." ${ }^{139}$

Sybil also told Barbara Walters that the National League of Families was "trying to make the world aware of the desperate plight of the prisoners... . We have gone to many sources and many spheres of influence to try to make all people of their desperate plight." Then echoing an idea about the North Vietnamese's desire for respectability in the eyes of the world that she had read about between 1965 and 1966-and that she discussed in an exchange of letters with Averell Harriman, President Johnson's Ambassador-at-Large for POW matters, she turned her comments toward the North Vietnamese. Confidently she said, "We feel that if they are criticized that they will soon

\footnotetext{
${ }_{139}^{138}$ (See note 138.)

Ibid.
} 
Developing an Organization for Exposure of the POW and MIA Issue see the shortsightedness of incurring world disrespect for the sake of using our men as political pawns."

Thus, by the time the national organization was not only incorporated but also formed, it already had a clear-cut message. Equally interesting is what the message did not include: the organization's message said nothing about the legitimacy (or lack of legitimacy) of the war; nor did it endorse any political party or political candidate. The National League of Families, in fact, had a standing principle to remain neutral and refrain from public criticism of elected officials. As the war lengthened, the commitment to this principle was increasingly tested and the National League had to develop ways to balance a growing push from some of its members for political involvement, on the one hand, and the earlier commitment to remain non-partisan. But, in Sybil Stockdale's 1970 interview with Barbara Walters, the non-partisan message was clear and unequivocal: "The organization has taken the position that we ... do not feel qualified to say how the problem should be solved. We want to make the world aware of the truth and ... there are many more qualified than we are to come to a political conclusion."

Decades later, the other women I interviewed affirmed that the clear and straightforward message that Sybil communicated during the interview with Barbara Walters was, indeed, the organization's message and not just Sybil's personal beliefs. Chloe Moore, for instance, recalled that the group's mission was to constantly bring before the public North Vietnam's failures with respect to "abiding by the Geneva Convention." Similarly, Shirley Stark indicated that members of the organization held out

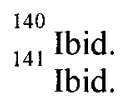




\section{Chapter Six}

the hope "that the more Americans became aware of what the truth was and what was really happening — that it might make a big difference."

Even Sherry Martin, who earlier had articulated a somewhat different goal for the group, eventually saw the national organization's message as being about humane treatment. Sherry told me that she was troubled by the American public's lack of concern with or interest in the POWs' plight. Even decades later, she stated, with considerable passion: "The whole populace of the United States should have been up in arms about the whole situation." She also talked about how she and the others understood that the public's apparent ignorance and indifference resulted, in part, from the fact that the POW issue did not directly "pertain to a majority of people" in the way that it did to the family members who made up the organization's membership. This hurdle, however, according to Sherry, became a motivating factor for the group to get its message out and "to keep that ball rolling [and] not to have it stagnate at all." Sherry added: "It was very important to keep this issue [about the need for humane treatment] before the American people."

Alice Stratton said the same thing about the organization's message that the other women I interviewed had said. Alice, however, did acknowledge that, even early on, there were disagreements among wives and family members about whether the organization should speak out against the war. She also noted, however, the commitment of the group's members to refrain from discussing their disagreements in public. Her position on this matter seemed to have been shared by most of the group's members: "I just think that [taking a position on the legitimacy of the war and engaging in partisan political battles about the war] would have diminished our message, and we would be 
Developing an Organization for Exposure of the POW and MIA Issue seen as one more interest group." The goal, Alice said, was to "continue with that one message-awareness of their treatment."

In retrospect, this thinking seemed to reflect considerable wisdom, and the decision not to engage in partisan politics appears to be a significant variable in explaining the influence of the group. As long as the group limited its discussions to the topic of prisoner treatment, the group, by virtue of representing wives and other family members of the prisoners, could speak with authority and legitimacy. The group members could also speak with one voice and provide a unified front; such unity would have been lost had the group strayed into other issues on which there was considerable disagreement within the group.

The importance of this unity should not be underestimated. Sandy Dennison, for instance, emphasized that not only was their simple, straightforward, and consistent message important to the group's success, it ultimately was the bond among the wives and families that made it possible for the organization to "move mountains." Furthermore, even the effectiveness of the group's message was inextricably linked with the messengers who delivered it. As long as the message was limited to the treatment of their husbands, sons and relatives; members could speak with undisputed authority. To quote Sybil, when asked about where she and the other members of the organization got their authority to speak on the POW issue: "Why would we not have authority? They were our husbands." 


\section{Chapter Six}

\section{Strategies}

"We were determined not to let the issue die."

\section{Marty Halyburton}

"We thought this was a major American problem!

We were trying to make it a national interest."

Sherry Martin

"Shutting our mouths wasn't working."

\section{Shirley Stark}

Essentially, the story of the development of the formal organization's strategies is very much like the stories that have already been told about the development of many of the other aspects of the organization. Like the story of the development of organizational structures, for example, the story of the development of strategies was one of improvisation and incremental change. Marty Halyburton acknowledged the absence of a grand design and the initial ad hoc approach to strategy development by laughing and stating, "There wasn't a plan; there was no planned strategy!" However, she quickly added that, while the wives were short on knowledge about how to do things at the start, they had a clear sense of what needed to be done. She said when the "wives got together to sort of work out their strategy," they were clear that they "wanted to make sure [governmental officials] knew they had to do something. They just couldn't sit there and shove it under the rug."

This clearly defined purpose, in turn, quickly made certain strategies self-evident. Retrospectively, Mary mused: "The...strategies were mostly [a] practical, sensible outgrowth of the circumstances. The circumstances were the foundation for the 
Developing an Organization for Exposure of the POW and MIA Issue strategies." She went on to explain: "The men were prisoners and we wanted and needed information about them. We wanted identification and accountability of what had happened to them. We wanted to improve their care and circumstances. And, we wanted to have them released, though we recognized that this was unlikely until a political solution was reached. We needed to have people know their plight and ours. . . The provisions of the Geneva Convention Relative to the Treatment of Prisoners of War were not being observed. The Red Cross was not being allowed in."

Given the agreed-upon need articulated by Mary and others, certain strategies quickly appeared. According to Jenny Connell Robertson, these strategies involved using methods to "contact representatives. . . the media. . . . and other people." Here, again, the strategy story aligned with other aspects of the organization's story that have already been told, because many of the most obvious strategies to accomplish the group's purpose were the same strategies members of the organization had used before the group became a formal organization.

Chief among these already tried and true methods were personal visits, letter writing, public speaking, and openness to innovation from others. Sybil Stockdale had developed and used these strategies even during the period when, as Marty Halyburton noted, the wives did not have "a whole lot of options" because of the government's "Keep Quiet" directive.

Personal Visits

Many of the women I interviewed spoke about various personal visits they made on various government or military officials either within their geographical area or in Washington DC. Most of the women, however, took the lead of Sybil Stockdale, who by 


\section{Chapter Six}

1968 had become adept at working the system to obtain appointments - especially through the office of Commander Bob Boroughs. Part of Sybil's motivation came from the lack of or the perfunctory response she received from the telegrams or letters she had written to government and military officials. In May 1966, Sybil traveled to Washington DC and met with Mr. Philip Heymann, Averell Harriman's assistant. Her first visit was followed by a personal visit three months later in August with Ambassador-at-Large Harriman. The meeting with Governor Harriman lasted for two hours, which focused on the North Vietnamese threat of trying the prisoners as war criminals. That same month, August 1966, she met with the Chief of Naval Operations, Admiral David L. McDonald (she requested her husband's official status to be changed from "missing" to "prisoner") and later with Vice Admiral B. J. Semmes, Jr., at the Bureau of Navy Personnel. During her meeting with Vice Admiral Semmes, she admonished him to write an information letter to all POW and MIA wives to keep them up-to-date on POW and MIA matters and to assure them that the Navy had not forgotten them. In May of 1967, she again called on Ambassador Harriman and Senator Everett Dirksen (R-IL). Two months later, she met with the new Chief of Naval Operations, Admiral T. H. Moorer.

\section{Corresponding with Government Officials}

\section{Letter writing.}

As noted, Sybil Stockdale was the early proponent of writing letters to government officials. She began the practice in September 1965 and perfected the strategy as the war progressed. With the formation of a formal national organization, as well as the demise of the government's quiet diplomacy policy, in fact, the scale and scope of the use of the letter writing strategy increased rather dramatically. 
Developing an Organization for Exposure of the POW and MIA Issue

Indeed, the sheer volume of mail the women could deliver to one or more government leaders was rather astounding. And, over time, the League members added international leaders to their list of people with which they corresponded. Letter writing campaigns also targeted television stations, newspaper and magazine editors and writers, public personalities, and corporations. In short, a strategy that had developed out of frustration and, in Sybil's words, a desire "to do something" when wives and family members felt constrained by government directives to them, became one of the formal organization's most potent and effective strategies.

To implement the strategy organizationally, Sybil would inform the wives: "We'll have a letter writing campaign." She would then compose three sample letters. Typically, the sample letters were brief and straightforward comments. They might include a comment like: "You know we didn't agree with what you said in the newspaper, please explain yourself."

Wives and other family members were strongly encouraged to translate the contents of the sample letters into their own words, so their letters did not have a canned feel or smack of being merely a form letter. At times letter writing campaigns responded to particular incidents, statements, or events, but, often, they were undertaken to simply remind elected and appointed officials that the family members were still around and to "give them [i.e., the government officials] a little bit of a boost" into action.

The domestic letter writing campaign was an absolute necessity according to Sherry Martin. She noted that it was the way to ask questions and keep pressure on elected and appointed officials in Washington. With a sense of urgency she said, "We had to do that to get them to respond to us . . to tell us." Sherry then recalled the 


\section{Chapter Six}

"continuousness of having questions ... going into our Representatives and our

Congressman." Letter writing campaigns and admonitions to persevere among wives

became part of their routine to keep the message out and buoy each other. Sherry stated:

"We would say to our fellow wives: 'Write your State Congressman. Tell him your

situation. Ask him what he's going to do about it. Ask him what the government policy

is.'" Then, sounding a bit like Sybil's comment that certain governmental officials needed

"a little bit of a boost," Sherry indicated that she considered the letters as a way to "pick

on him [the government official] a little." Sherry told me that by the late 1960 s there were POW and MIA wives and family members representing every State and they, all, "just kept pinging away."

\section{Other letter writers.}

Others added to the "pinging" noise. Alice Stratton and Phyllis Galanti, for instance, told me of ordinary citizens, on their own initiative, writing letters, which, both said, was an indicator to governmental officials that people cared about the issue and were not only willing to write but also to demand action. During an interview with Alice Stratton, she recalled the very first letter she wrote on November 1, 1969 to the Palo Alto Ministerial Council. In that letter, she requested help and prayers for the men; she specifically requested that people "also write letters."

Sherry Martin also acknowledged the contribution of non-League members who assisted with "typing letters to various Congressmen" (even though she indicated that she wrote and typed her own letters). Phyllis Galanti also remembered "hippies" working side by side with "some really right wing people" when producing letters for various POW and MIA campaigns. 
Developing an Organization for Exposure of the POW and MIA Issue A unique approach to contacting government officials: the "telegraph-in."

By the time President Richard Nixon assumed the presidency in January 1969 the National League, in Sybil Stockdale's words, "really became refined in response to specific events." One of the communication strategies the group employed was inspired by the tactics of war protesters. Sybil recalled that the late 1960 s was a time of "sit-ins" and "stand-ins" on college campuses and in governmental buildings across America in protest to the war of other civil issues of the day. She decided the National League would conduct a "telegraph-in."

Communicating with an estimated sixty wives across the country, who in turn communicated with other wives and family members, Sybil issued the directive to send as many telegrams as possible to President elect Nixon on Inauguration Day, January 20, 1969. According to Sybil, the message was simple: the wives were "asking him to give the prisoner situation a high priority in his administration." The result, she said, was over "two thousand telegrams on his desk that day after his inauguration."

The number, 2,000 had come from a conversation Sybil had had with Alexander Butterfield, Assistant Chief of Staff, and Special Assistant to President Nixon, at a function in Coronado, California, around 1998 or 1999. Sybil recalled that Butterfield, who was in Coronado to speak about his experiences in the Nixon White House, had told her privately that the "two thousand telegrams on his desk" the day after the presidential inauguration "really made a difference." There will be more on the White House's reaction to the organization's first "telegram-in" in the discussion of the White House's reaction to the women and the government's evolving approach to the POW and MIA issue in a subsequent section. 


\section{Chapter Six}

Two months later, the organization conducted another telegraph-in. This time the telegrams were sent to the Paris Office of Xuan Thuy, Chief of the North Vietnamese Delegation to the Paris Peace Conference. ${ }^{142}$

The telegraph-in strategy, as Sybil and others recalled, was used on only two occasions. The networking strategy employed with the two telegraph-ins to generate such a large amount of correspondence to officials at a particular point in time, however, was used in numerous letter-writing campaigns to public officials. Some of these snail-mail versions of the telegraph-in approach were used to get officials to attend to the POW and MIA issue; others were used to challenge or register displeasure with an official's actions or public comments.

\section{Petition drives.}

Some of those interviewed - though certainly not all of them-also recalled various petition campaigns. Shirley Stark and Sandy Dennison remembered wives taking turns sitting in front of various stores, requesting signatures to support their efforts for the North Vietnamese to abide by the Geneva Convention. Sandy also mentioned they would have mimeographed letters available for people to send to Congressman or other officials. Shirley recalled that some people were hesitant to sign POW and MIA petitions for fear the North Vietnamese would somehow do something to them personally. Sherry Martin remembered that the wives "felt that the more people [they] could get to sign this kind of thing and [then] present these volumes and volumes of petitions to the powers that be, that, at least, they would see this is not just some little interest group."

\footnotetext{
${ }^{142}$ Le Duc Tho succeeded Xuan Thuy in February 1970.
} 
Developing an Organization for Exposure of the POW and MIA Issue

\section{Corresponding with world leaders.}

It was not only the letter-writing campaign that changed with the formation of a national organization but the scope of letter writing activity expanded as well. For instance, organization members no longer limited their letter writing to government officials within the United States. Rather, world leaders were added to the list of people with whom the League's members corresponded.

Marty Halyburton recalled Sybil's guidance in the early stages of the campaign to write "letters to heads of state that maintained diplomatic relations with North Vietnam." Soon, she began a morning ritual of writing about "twenty letters a day," which targeted foreign governments and members of Congress. Marty, at the time and decades latter, was uncertain about the effectiveness of the international letter writing campaigns. But she spoke of the value of simply involving the wives and other family members in the activity: "It's pretty hard to sit back and do nothing," she said. She also echoed Sybil's words about this activity alleviating some of the feelings of helplessness among family members: "I think there obviously were a great many wives, mothers, fathers, brothers, and sisters who felt like this was something positive that they could do."

Alice Stratton was considerably more certain about the positive impact of the group's international letter writing campaigns. Alice, in fact, was certain that the letter writing campaigns had been significant and influential in gaining support and changing attitudes about the plight of the prisoners not only within the United States but also within the international community. Laughingly, she said that she did not "know if there has ever been that many letters written" to international leaders. She remembered "truckloads of letters" being "dumped . . . on the embassies." Like the number of the 


\section{Chapter Six}

women I interviewed, Alice also alluded to prisoners who, upon coming home in 1973, spoke of living conditions and treatment improving significantly after 1970. According to Alice and others, this alteration in treatment is evidence that the North Vietnamese "knew the prisoners were a liability if they didn't come back. ... We were at least keeping them alive while they were there."

As the war continued and the number of men imprisoned in North Vietnamese increased, the international letter campaigns also continued. Though Phyllis Galanti's husband was shot down in June 1966, she spoke about the "fabulous letter writing campaign in 1971" in Richmond, Virginia. This letter writing campaigned differed from previous ones in at least one important respect: The letters that had been generated were not mailed; instead, she went as a representative of the Richmond delegation to Stockholm, Sweden, considered an intermediary nation, to personally meet with Swedish officials and deliver the letters to them. This personal delivery strategy was repeated in 1972 when Phyllis and two other POW wives, under the auspices of the National League, traveled to Paris and then Versailles for the International Communist Conference on Indo-China, a conference that included over 800 delegates from communist countries. Armed with letters, as well as petitions, the group attempted to meet with various communist officials, including the Pathet Lao and the Viet Cong. Unfortunately, the group was rebuffed and the crop of letters remained undelivered.

Communicating with government officials indirectly rather than directly.

As she told me of the group's failure to deliver the letters, however, Phyllis recalled a more positive part of the international letter writing story. She noted that League members began targeting "newspapers in foreign countries." The message in 
Developing an Organization for Exposure of the POW and MIA Issue these letters was consistent with the message the organization was delivering in America: The men were being mistreated and the Geneva Convention Relative to the Treatment of Prisoners of War was being violated. Because of my request for an interview and our subsequent discussion about letter writing to international newspapers, Phyllis opened her personal archives, which she had kept closed for decades, and found newspapers from Berlin, Germany and Cairo, Egypt dealing with and headlining POW and MIA matters.

Of course, the women did not limit their letter writing to the foreign media. Domestic newspapers and other domestic media outlets were also recipients of the group's targeted correspondence. In fact, over time, the organization's leaders became quite astute about the value of communicating to policymakers through letters written to the media. For example, by 1970 it was common for Sybil Stockdale to correspond with the highest-ranking officials of government, including the President. However, during one of my interviews with her, Sybil told me about watching a television interview with President Nixon, conducted by Dan Rather, in the fall of 1972. It was her intention, as well as her practice, to "listen very carefully to see if President Nixon mentioned the prisoners ... and he didn't," Sybil recalled. When he did not, Sybil recalled that she "was really mad" and decided to share her anger with the President. Because of timing issues being of the essence, she corresponded in telegram rather than in letterform. But there was also a more important deviation from her standard operating letter-writing procedures: She decided to send her correspondence to Dan Rather and merely copy President Nixon. She explained her very conscious decisions as follows: "They had taught me... they had taught me so well exactly how the system works. If you wanted to communicate anything to the White House and be strong about it, you sent your 


\section{Chapter Six}

message directly to a reporter-preferably one [with] the influence of Dan Rather and then you sent a copy to the White House. . . that's how you communicate with them the most strongly."

The telegram generated a phone call from the White House by General Hughes who, according to Sybil, was not too pleased with her criticism of the President being sent to Dan Rather than to the President, himself. Even though General Hughes eventually apologized for his comments, the call, however, simply reinforced to Sybil the correctness of the lessons about how to influence the White House in the manner that "they had taught."

\section{Utilizing the Press}

Sybil's decision to contact Dan Rather illustrated another strategy used by the National League: send messages to pubic officials via the media. Once again, this strategy had been tried long before forming a national organization was even contemplated.

Before a national organization was formed, however, the women had had limited success to interest the press in telling their husbands' story. Mary Winn, recalled, for example, that she, with approval from the Air Force, went to the Minneapolis Star in May 1969 to talk to a reporter. "The young reporter astonished and confused me," Mary said. After listening to her he announced, "That's not news, lady!" As she thought about the reporter's, she realized he was right— the "POWs had been in Hanoi too long to be news."

Mary was not the only one who experienced rejection when telling their story to the press in the early years. Bonnie Singleton went to the Dallas Morning News with three other wives, with the same intention that Mary had had: to tell their story and 
Developing an Organization for Exposure of the POW and MIA Issue interest the paper in telling their story to the paper's readership. After making introductions in the reporters' bureau, a reporter conducted an interview. For forty-five minutes, their reporter, Mr. Simmons, listened and, then, promised to write an article based on their story. Bonnie told me that she and the two wives who had accompanied her were surprised and dismayed with what was published. She said: "The next day we saw two lines on the page opposite the obituary section: 'Two wives husband's are missing in action in Southeast Asia living in the Dallas area.'"

Even when papers did carry stories about the wives and their husbands, the results were, often, less than satisfying. Shirley Stark, for example, bemoaned the fact that "the press was not very good about ... putting in what you said."

Once the group went national - a move that, as already has been noted, was stimulated by a rebuff by the reporters from Look magazine - things began to change. How much the mere formation of a national organization factored into the change cannot be determined. What is obvious, however, is that leaders of the national organization were proactive in getting the attention of the press.

In July 1969, just a month after Sybil Stockdale, in her words-waved her "magic wand" in response to the Look magazine rebuff and "magically" transformed the League of Wives into the National League — she traveled to Washington DC to join other wives and parents in a meeting with Melvin Laird, Secretary of Defense in the Nixon administration. On her way to the meeting, Stockdale stopped in New York City to try to generate publicity for their cause. She had requested meetings with Life, Time, Parade, the New York Times, and the Today show. Only Parade had an interest and provided her with a forum to tell — and eventually publish — the wives' story. Elated by this turn of 


\section{Chapter Six}

events, she showed up the New York Times unannounced. By some good fortune, she met with Mr. Palmer, one of the editorial assistants. Palmer provided her with a list of newspapers he felt were highly influential, even though their circulations were small, but ones he felt the League needed to target. Since she was on her way to see the Secretary of Defense in Washington DC, Palmer also gave her the name of a New York Times reporter in DC to contact after her meeting with Melvin Laird. The efforts with this type of media networking resulted in the publication of a nearly full-page article in the New York Times on July 31, 1969.

Area coordinators and others working at the local level also began to experience some success in dealing with the media. Phyllis Galanti, for example, remembered a "wonderful supportive press" in Richmond, Virginia, though she also noted that wives in other cities had experienced a certain amount of hostility from the press, "particularly [the women in] San Francisco and New York had different experiences." (Whether this "hostility" continued after the formation of the national organization was not clear though Alice Stratton, who lived in the San Francisco Bay area, seemed to adjust and navigate the apparent hostility.) When I asked Phyllis what League activities had the greatest influence on people like Senator Ted Kennedy (D-MA), Senator Bob Dole (R-KS), administration officials, and White House staff, she did not hesitate in offering her answer: "We were getting to be very good with the press and the press was really following us ... I think this got their attention."

One example of individual members being successful with the press at the local level involved Shirley Stark. During my interview with Shirley, she mentioned an activity she initiated in 1967 when there was a League of Wives but no National League. She 
Developing an Organization for Exposure of the POW and MIA Issue contacted the editor of the local newspaper and requested that, on the Editorial page, a small section be set aside to count the number of days since the first POW was shot down. The editor agreed to do this; August 5, 1964, the day the first POW, LTjg Everett Alvarez, was shot down became day one. This simple idea and resultant daily publication contributed, in a small way, to the wives overall objective to keep the POW and MIA issues in the American conscious.

Working at the national level, Sybil Stockdale also understood that the press was vital to the campaign of the National League. She also understood, however, that, even though she knew that the wives "needed them [reporters and other news people] desperately. ... we didn't want to be used by them-we wanted to use them." The goal was a unique balancing act to neither irritate nor alienate the press while retaining at least some control over the telling of their story. I asked Sybil if she thought the wives succeeded in making the press their ally, and she responded, "Oh, absolutely without any question." She added, "I think when they [governmental officials] saw how the media was responding to us and how the human-interest story was spreading across the country."

All of this, amazingly, was accomplished without the assistance of public relations professionals. During my interview with Phyllis Galanti, in fact, she recalled having been asked a question about what public relations firm was representing the National League and wives. To her such a question "was such a riot because we just sort of stumbled ... we just sort of made this up as we went along." She acknowledged, however, that "we knew inside and out [what we were talking about] ... There was no way the press could catch us." 


\section{Chapter Six}

In fact, the wives eagerly (but informally) shared tips on dealing with the media. Once again, a strategy before the advent of a national organization was continued once the national organization was formed. Of course, once there was a national organization existed, there was a mechanism to create formal methods to supplement informal ones. Phyllis, for instance, provided me with a copy of the National League's basic primer on How to Handle Your Contacts with the News Media (Appendix G). The document provided wives and family members with not only pertinent interview guidelines but also strategies to further the National League's goal of educating Americans about the plight of the POWs, POW and MIA issues, and other related matters.

The absence of public relations professionals was not accidental, however. When Sybil met with Mr. Palmer, the Assistant to the Editor of the New York Times, he told her that the "slightest taint of Washington slickness was the surest turn-off for the media." Decades later, Sybil recalled that making media outlets their "strongest allies" necessitated that the National League maintain its integrity. Undoubtedly, maintaining integrity — or at least the perception that integrity was being maintained - was facilitated by the League's do-it-yourself approach to dealing with the media.

\section{Utilizing Television}

The national organization also embraced strategies that were not used extensively in the earlier, more informal campaigns. One of these newer strategies involved using television to communicate the group's message and indirectly influence government decision makers. Sybil Stockdale, for instance, viewed television as the most influential public medium. Reflecting on all her years of leading the National League and engaging in numerous activities to keep pressure on governmental officials, she commented, "The 
Developing an Organization for Exposure of the POW and MIA Issue power of television is absolutely staggering ... mind-boggling." Even though television was a relatively new medium at the time, she concluded: "If you're not on television, you're nobody. You're nothing."

As her previously discussed interview with Barbara Walters clearly indicates, by January 1970 Sybil managed to turn around her initial rebuff from the Today show and got herself — and her message about prisoner abuse—on television. Some wives at the local level also participated in television interviews. Like most people, the more they were in front of the camera, the more skilled they became in using the media to get the organization's story across to the American people and to influence, albeit indirectly, government officials to attend to the treatment of Vietnam prisoners.

\section{Public Speaking as a Strategy}

Whether or not there was a television camera present, the members of the organization were encouraged to speak publicly about the plight of the prisoners. As a result, public speaking became part of the list of standard operating strategies used by the National League.

In the early years, of course, the government's Quiet Diplomacy policy (or, the use the wives' nomenclature, the Keep Quiet policy), inhibited any public (and, often, even private) discussion of the POW and MIA issue. Like so many other things about the group, serendipity played a part in changing this situation. In early 1967 , the principal at the school where Sybil Stockdale taught was also the President of the Kiwanis Club in Imperial Beach, California. At the last minute, his scheduled speaker for a meeting of the group had cancelled, and this turn of events led him to ask Sybil to speak. As Sybil 


\section{Chapter Six}

remembered, his request was simple: "Tell about your husband's circumstances [and] about your circumstances."

Sybil agreed to speak - despite the government's directive to keep quiet - and what she discovered, consequently, was the publics' lack of awareness about POW and MIA issues. This lack of awareness compelled her to continue to challenge the government's existing policy and to make additional speeches. She also began to encourage others to speak out, and, both because of her positional power as the leader of the squadron wives' group and her personal power and the relationships among the wives that had already begun to be cemented as early as 1967 , other wives responded enthusiastically.

As the wives began to organize themselves-first as the more-or-less informal League of Wives of American Vietnam Prisoners of War, then as the still somewhat informal National League of Families of American Prisoners in Southeast Asia and, finally, as the legally incorporated (but still somewhat loosely coupled) National League of Families of American Prisoners and Missing in Southeast Asia-they became the definitive spokespersons for the POW and MIA issue. "We went around and gave speeches. We'd go anywhere to do our talking," Sybil told me. This speaking, in all sorts of venues, produced two results, according to Sybil: It spread the word and involved the public in POW and MIA issues. All the wives interviewed were involved with public speaking, although to varying degrees. Mary Winn talked about being on early morning radio talk shows and speaking at schools. She also told me that she spoke at Red Cross meetings, including both the annual meeting of the Red Cross in Milwaukee, Wisconsin, and the annual national convention of the Red Cross held in Chicago - at which she was 
Developing an Organization for Exposure of the POW and MIA Issue the keynote speaker. In Mary's words, she "took every opportunity to make known the plight of our prisoners." She also indicated that the activity provided some personal psychological and emotional relief: "It helped me, that is, to hurt less-not to focus too closely on [her husband] but to work for the benefit of all the POWs and their families."

Sandy Dennison, another frequent public speaker, recalled that, in their speeches, the wives would challenge groups, even high school audiences, to take the message home and ask other family members if they were aware of the plight of the prisoners. Phyllis Galanti also attempted to recruit supporters in her speeches and was quite successful in mobilizing an entire city to support the campaign to ensure humane treatment of the prisoners and adherence to the Geneva Convention agreement on prisoner treatment. Because of one speech, Phyllis met two individuals who wanted to help the POW and MIA families. In her words, "They just turned the city [Richmond, Virginia] upside down ... they got in touch with women's clubs, church groups, and schools and said, 'Do you need a speaker?"' They not only arranged for Phyllis to speak to groups; they, themselves, took on the speaker role when required to broaden the distribution of the message.

Like the other wives I interviewed, Karen Butler considered the speeches extremely useful in making people aware of the plight of the POWs and issues concerning MIAs. Chloe Moore indicated that she, also, made speeches that focused on making people aware of the obligation of North Vietnam to abide by the Geneva Convention. In her mind-and in the mind of the other women- the speeches were not the platform, and never became the platform, to appeal for the release of the men; rather, awareness and human treatment was her central theme. 


\section{Chapter Six}

Marty Halyburton was another wife who was frequently on the podium. Initially Marty realized some audience members did not know how to respond to the stark and disturbing story she was telling, but she discovered that, when the wives were open and candid, a speech "opens the door" for greater discussion. She also acknowledged the uniqueness of each story told, because, for each POW and MIA, there were many personal family stories. She believed the greatest benefit of the public speaking campaign was that POWs and MIAs, along with their families, became "human" to listeners. Names were given faces; it "wasn't just numbers." In her estimation, the human touch "made this a real issue" for the American people. Phyllis Galanti also voiced this same sentiment: "The more you can personalize it and get away from numbers and talk about your husband-that was better."

Marty told me of one especially memorable speaking engagement. Marty received a phone call from a college friend, whose father was a lawyer in Atlanta, Georgia. He asked her if she would address a group of attorneys in the near future, and she agreed to do this. After a couple of weeks, she received another phone call from the same individual informing her that a keynote speaker cancelled his appearance at the last minute; he asked Marty to push up her speaking date to that evening. Once again, Marty quickly agreed to the request. On entering the hotel in downtown Atlanta, she learned she would be addressing the American Bar Association and substituting for Senator Bobby Kennedy (D-NY). Marty recalled looking at the podium and seeing a multitude of microphones intended to capture the speech of the Senator. Marty rose to the challenge. Her speech led to a call from Ross Perot, who requested her presence at a news conference in Atlanta on POW and MIA issues. 
Developing an Organization for Exposure of the POW and MIA Issue

Even though all the wives spoke publicly, public speaking was not everyone's

forte. Alice Stratton, for instance, said she "was not accustomed to public speaking" and was nervous most of the time. "To some degree," she said, "nervousness is good because that means you're going to make sure you do a good job." Over time, however, she felt she improved but acknowledged the emotional aspect was always in her heart and mind.

Despite her anxiety about speaking in public, Alice indicated that did not consider tears useful. "The tears were always there behind the acceptance and behind the façade . . . the sadness was always there." She recognized a certain amount of emotion was effective but that it could also obscure the message. Therefore, she controlled all emotion as best as possible. That is why she had what she called "a standard prepared speech." She only changed it after POW Doug Hegdahl was released by North Vietnam, to which, she incorporated into her "stump" speech references of Hegdahl's confirmation of torture. Alice would also, on occasion, change her standard speech and encourage citizens to engage in a letter writing or telegram initiative being planned by the wives. Even if no specific initiatives were being planned at a given point in time, Alice said that, in her prepared speech, she always "had a whole list" of individuals for people to write.

Although Alice relied on her own standard speech, there was not a prescribed speech for the wives to make. Phyllis Galanti noted that the wives would share "what kind of things in our speeches got a good response," but she and others confirmed that, in the area of speech making, as in most other areas, the National League remained the quintessential grassroots organization. Marty Halyburton added that, even without a "patent[ed] speech," the group had "a compelling message." Once again, it seems that authenticity trumped technique. 


\section{Chapter Six}

\section{Refraining from Partisan Politics and Taking a Position on the War}

In discussing group members' speech making, Phyllis Galanti stressed that the members' speeches never asked the audience to take a specific "stand on the war." This commitment to neutrality on the war issue and a more general commitment to nonpartisanship, both of which were previously discussed, must also be added to the list of strategies employed by the group. These strategies, in fact, were adopted very early in the process.

Phyllis Galanti, for example, spoke of the group's conscious decision not to choose political sides and to ensure activities under the "flag of the National League" remained nonpartisan. This decision, in her mind, ensured "support from the whole spectrum" of politicians and public alike.

Sherry Martin also thought the group's commitment to nonpartisanship and neutrality on the war issue assisted the wives in establishing and maintaining their influence. Similarly, when Alice Stratton was asked whether she thought keeping criticism of the Johnson and Nixon administration private rather than public was effective she replied, "Oh, absolutely." Alice argued that being in "sync with the government" and refraining from "criticizing their conduct of the war" were important elements of the group's overall strategy. She added, "I think that is why we eventually won over the government." Alice also viewed the nonpartisan policy and non-criticism of elected officials as a way for the wives to be "seen as unified" and "saying the same thing."

In fact, the decision to say nothing about the war, itself, was indeed important in retaining at least the appearance of unity and for sending a unified and clear message about the treatment of the prisoners. In actuality, the women and other family members 
Developing an Organization for Exposure of the POW and MIA Issue were not unified on the legitimacy of the war and the different parties' proposal for dealing with the war issue. All of the wives I interviewed, in fact, alluded to this lack of unity. Phyllis Galanti, for example, acknowledged the wives held strong and often differing political feelings, but in most cases agreed that they would not have their feelings "voiced publicly." And Alice Stratton even acknowledged that "there were some splinter groups" who departed from the non-partisanship strategy; these groups "went off with their drumbeat against the government," according to Alice.

For the most part, however, those who remained in the National League's tent abided by the nonpartisanship strategy, especially in the early years of the National organization when the group was still attempting to make the treatment of prisoners a public issue. Alice Stratton, for instance, acknowledged that she and others "stuck to the party line of the National League" despite their "private gripes."

Adhering to this particular party line became increasingly difficult for some members of the group, especially after the group had been successful in getting the POW and MIA issue on the national policy agenda. What irritated a number of them was that the war dragged on with no conclusion in sight, participants at the Paris Peace Talks argued about such mundane matters as the shape of the table, and North Vietnamese officials continued to snub international protocol. When political factions did develop, one of the members of the National League, for example, agreed to second the nomination of George McGovern at the Democratic convention. Other wives, out of exasperation, protested the handling of the war in front of the White House during the summer of 1972. 


\section{Chapter Six}

There were also efforts in some states and regions to form alliances with groups that had obvious political agendas. Bonnie Singleton, for example, spoke of a group of anti-war activists who "wanted to be the ones to bring out the letters from the prisoners and take letters to the prisoners." They would act as a courier of sorts, who also gave antiwar groups desired publicity. Jane Fonda was part of one of the first groups of people to go to North Vietnam for this purpose. While Bonnie saw this turn of events in positive terms because it signaled, "everyone around the world was drawn to this issue of the Prisoners of War," other members of the organization saw it as a direct challenge to the group's commitment to remain nonpartisan and neutral.

As alluded to previously, the establishment of alliances with partisan groups resulted in the inclusion of a policy into the by-laws of the organization as part of its legal incorporation in the summer of 1970 . The by-laws stated: "Members may participate, facilitate and develop activities with other private or public groups or organizations and governmental agencies which are working to achieve the same humanitarian objectives as the League, but the League's endorsement of these activities or organizations shall be subject to the approval of the Board of Directors." ${ }^{143}$ Clearly, the wording of this particular by-law evidences an effort to balance the growing desire of some of the organization's members to choose up sides in the Vietnam debate with the group's articulated commitment to nonpartisanship and keeping the group neutral on the war.

Interestingly, even those who remained committed to nonpartisanship as a strategy began to modify their interactions with public officials somewhat. Even as early August 1966 Sybil had raised critical questions about the conduct of the war with

\footnotetext{
${ }^{143}$ Phyllis Galanti, unpublished data, private collection.
} 
Developing an Organization for Exposure of the POW and MIA Issue Admiral David L. McDonald, the Chief of Naval Operations, and in May of 1967, she raised similar issues during a private conversation with Republican Congressional leader, Senator Everett Dirksen (R-IL). In December 1967, Sybil Stockdale sent the following clear-cut-and quite confrontational - telegram to Ambassador-at-Large Averell Harriman: "I am enraged at the flaunting of mistreatment of prisoners by the North Vietnamese. What are we doing about it? I beg you to support our men who are in such agony. Yours Sincerely, Mrs. James B. Stockdale."

These challenges, especially by the League and National League, were initially, all made out of the view of the public eye. By 1972, however, as was alluded to in the earlier discussion of the group's use of the press, Sybil's decision to write to Dan Rather (and copy Richard Nixon) rather than to the President, himself, represented a willingness to be at least somewhat confrontational in public as well as in private.

Years later, Sybil confirmed that she knew precisely what she was doing when she made the decision to contact Dan Rather and only copy President Nixon. And she indicated to me: "I got the results I wanted-I got their attention!" Sybil noted that, initially, "getting their attention" resulted in a rather belligerent phone call from General Hughes, the military liaison officer in the Nixon White House. Within twenty-four hours, Sybil received a second phone call from General Hughes. This time General Hughes apologized for his earlier response; he also said, according to Sybil, "[In the future] you can use my plane to travel from Coronado to Washington DC, Mrs. Stockdale." Sybil told me that she replied: "Mrs. Stockdale will buy her own ticket. She will pay her own way."

The nonpartisan policy, in fact, never implied a lack of commitment to the overarching goal to bring about a governmental policy shift. As Alice Stratton told me, 


\section{Chapter Six}

"If you don't bring about some change in what's happening, what are you doing it for?" And, even though Chloe Moore felt "there was a lot more political stuff going on but," she still furthered the goals of the League of Wives and National League with official visits, letters, and attendance at League events in Washington DC. Nonpartisanship, in other words, was always a means to an end rather than an end to itself. As the war continued and the peace talks showed no indication of progress, the utility of this strategy began to be questioned, in modest ways by some and in ways more dramatic by others.

\section{Working With (and, in Some Cases, Helping to Form) Affiliated Groups}

The reference to working with other organizations in the previous section speaks to another relatively pervasive strategy employed by the National League. Again, the use of this strategy predated the founding of the national organization, as the discussion of the formation of Concerned Citizens of America in an earlier part of this discussion indicated. As was noted, earlier, the plan to form this organization was concocted by Sybil and a concerned citizen who was refused membership in the League of Wives (the group that predated the national organization) because he was, obviously, not a wife. Even other family members were not permitted to join the organization at that time. Thus Joe McCain, brother of POW and now Senator John McCain, was forced to join the Concerned Citizens group rather than the still somewhat informal (and local) organization that the wives had begun to create.

Operationally, the distinction between the two organizations was not particularly significant. Concerned Citizens (which was, like the wives' group, nonpartisan) and the League of Wives frequently worked together to accomplish the goal of calling attention to the prisoners plight and the failure of the North Vietnamese to abide by the Geneva 
Developing an Organization for Exposure of the POW and MIA Issue Convention agreements about the humane treatment of prisoners. For example, for some time, Joe McCain worked in an office space at the YMCA in downtown San Diego, California, that had been donated to the League of Wives. In fact, decades later, Sybil chuckled as she told me that Joe, in effect, "moved in-free rent. The volunteers said, 'I'm not going to come anymore until Joe McCain gets his underwear out of these desk drawers!"

The close working relationship evidenced between the League of Wives and Concerned Citizens of America was duplicated with other organizations. One such group was United We Stand, an organization formed by Ross Perot to publicize and generate public support for the POW issue. Another group was VIVA (Voices in Vital America). VIVA was important because it generated the idea of selling POW and MIA bracelets. Each bracelet was a simple metal band that contained the name and rank of a POW and the date on which he had been shot down. Carol Bates Brown, who co-founded VIVA when she was a university student, provided an historical account:

The idea for the bracelets was started by a fellow college student, Kay Hunter, and me, as a way to remember American prisoners of war suffering in captivity in Southeast Asia. In late 1969, television personality Bob Dornan (who, several years later, was elected to the US Congress) introduced us and several other members of VIVA (Voices in Vital America) to three wives of missing pilots. They thought our student group could assist them in drawing public attention to the prisoners and missing in Vietnam. ${ }^{144}$

${ }^{144}$ MIA Facts, "The Origin of the POW-MIA Bracelets," http://www.miafacts.org/bracelet.htm. Attempts to contact Ms. Bates Brown were unsuccessful. 
Chapter Six

The student group initially circulated petitions and letters to Hanoi demanding humane treatment for the POWs. Soon they came up with the bracelet idea. The POW and MIA bracelets quickly became one of the most visible symbols of the plight of the POWs and MIAs. All of the wives, when interviewed decades later, acknowledged the remarkable impact of the bracelets. As Alice Stratton said, "The bracelet wearing was really smart."

The affiliation-with-external-groups strategy also was employed, to good effect, at the local level, most notably in Dallas, Texas. In 1969, after the formation of the National League of Families, Bonnie Singleton - a POW wife from Dallas, Texasimplement an idea she had that involved forming an affiliated citizen group called "Dallas Cares." Bonnie felt the POW and MIA families could not handle the magnitude of the task before them as an exclusive family group. Bonnie estimated that she, herself, spoke, on average, five times a week to organizations in the North Texas area. To begin to rectify the problem, Bonnie helped form a citizen group that, among other things, had a speakers' bureau. The group was housed at the Dallas Naval Air Station, which provided free office space and a telephone. The group's purpose was much like the National League's: to bring attention to the POW and MIA issue and compliance with the Geneva Convention.

Other "Cares" organizations sprung up in other communities, though the record of where is sketchy, at best. Bonnie indicated that she knew of "organizations all over the country" but she could provide no other details about what had happened in other communities where local organizations were a product of grassroots initiatives and informal networking with wives and family members in other cities such as Dallas rather 
Developing an Organization for Exposure of the POW and MIA Issue than a push from the national organization. During the interview, Bonnie was candid that Cares did not have a "national cohesion" or "any national base" like the National League of Families.

This lack of national direction resulted in some Cares groups affiliating with peace groups and, in effect, challenging the national organization's commitment to nonpartisanship and neutrality on the war. As was noted in the previous section, this challenge did finally result in a modest, defensive reaction of the newly incorporated national group, an reaction that took the form of a by-law that both permitted local discretion but made the National League's endorsement of local groups' affiliation with other groups contingent on the National board's approval.

\section{External Support}

"You cannot believe what some of these organizations and people did."

\section{Bonnie Singleton}

The previous discussion of strategies indicated that the National League quickly established ways of operating that limited organizational membership to family members and prohibited the soliciting of funds. It is also the case, however, that the National League could not have functioned without the financial support and in-kind contributions of a number of groups and individuals. Individuals also provided other sorts of invaluable support, as well. This section discusses the groups and individuals that the wives I interviewed mentioned as being essential to their effort.

Before discussing the particular external groups and individuals cited by the wives as being especially important to the organization's operation, it seems important to articulate two caveats. The first caveat is a reminder of a point that was made earlier in 


\section{Chapter Six}

discussing the organization's fiscal strategies: Sybil was adamant that individuals, companies, or organizations "all donated" to the organization and that the National League "never solicited" contributions. Thus, from Sybil's perspective, when an official within the Retired Officers Association, who Mary Winn knew, offered the National League office space at 1 Constitution Avenue in Washington DC after Sybil and Mary had paid him a visit, the offer was not the result of a solicitation. Since there appeared to be no quid-pro-quo, the offer could be accepted, much like when the YMCA of San Diego had offered the Concerned Citizens of America free office space in downtown San Diego. The distinction, here, in Sybil's mind, at least, was important because the accepting as opposed to soliciting donations ensured that no one would be able to question the National League's motives.

The second caveat is that the National League, on some occasions, refused contributions. Mary Winn recalled, for instance, that the group was offered "professional help" in the areas of fund raising and public relations. Mary recalled that Sybil rejected this sort of help because she wanted the wives and families to do the work themselves, "even if we don't do it quite as smoothly as professionals would." In short, the decision to reject assistance suggests that there was a conscious decision to tilt toward authenticity rather than technique.

With the above caveats noted, we can turn to brief discussions of the individuals and groups whose external support the interviewees most frequently mentioned. Heading the list of supporters and support organizations was Texas billionaire, Ross Perot. 
Developing an Organization for Exposure of the POW and MIA Issue Ross Perot $^{145}$

The wives I interviewed who met Ross Perot all acknowledged his dedication and commitment - even at great personal expense - to support their efforts to make the plight of the prisoners known, turn the POW and MIA issue into a media spectacle thereby bringing the issue into American consciousness, and a determination to hold the North Vietnamese accountable. Marty Halyburton affectionately referred to Perot as having a "bee in his bonnet" about the POW issue. She also noted, "Perot's work was very public and dramatic," which is exactly what the wives required. In Sybil Stockdale's opinion, Ross Perot did "marvelous and wonderful stuff for the POWs ... he put the issue on the front page." She added, "His support as a private citizen was extremely important" in that he not only was instrumental in obtaining publicity but funding trips to Paris for the wives. It was during one trip to Paris that Perot funded that a small group of wives asked the North Vietnamese, "Are we wives, or are we widows?" The question, publicized throughout the world and, consequently, it brought attention to the prisoners' plight.

Unlike most other supporters, Ross Perot had the financial ability and connections to bring attention to bear on the POW and MIA issue. Karen Butler referred to Ross Perot as a "media magnet." "[He] amplified everything we tried to do a thousand times over," Karen said. She characterized Ross Perot's efforts as "very significant and very effective." Shirley Stark indicated that she was grateful that someone of prestige and influence "cared." Mr. Perot declined to be interviewed for this research project but subsequently, and graciously,
agreed to permit the author to review his personal POW and MIA files post dissertation. During our short
conversation on July 21,2005 , I discussed some of the preliminary findings and how the women recalled
his support and contribution to the POWs and MIAs matter. 


\section{Chapter Six}

Other wives I interviewed also appreciated the commitment and contribution of Ross Perot. Marie Estocin spoke about a meeting at Hotel del Coronado, Coronado, California, that Ross Perot hosted. The meeting launched a cross-country caravan of vehicles to publicize the POW and MIA issue. The caravan gathered letters across the United States, which were then delivered to governmental officials in Washington DC: Marie said wives understood that this was another way to make the public aware of the prisoners' plight, as well as make a statement to governmental officials that it was their duty to "keep the wives informed."

Bonnie Singleton attested to Perot's generosity. At one point, Perot asked Bonnie what he could do to help her and the Dallas Cares organization Bonnie had started in her hometown. She simply requested bumper stickers to publicize the POW and MIA issue. She was not aware, at the time, of Perot's vast wealth or his influence. His wealth, at least, soon became apparent as Bonnie and her group were inundated with bumper stickers carrying an array of messages that included: "POWs Never Have a Nice Day" (an adaptive use of the 1960s colloquial saying, "Have a Nice Day!"), and "MIA-Only Hanoi Knows." Soon the Perot-funded bumper sticker campaign went national.

Bonnie also soon began to realize the extent of Perot's influence. She told me that Ross Perot arranged for Bonnie and her son to appear in a full-page article in the Dallas Morning News. According to Bonnie, the article centered on Perot announcing that "he had met this three year old boy who had never seen his father and who deserved an answer about whether his father was alive or not." His objective, she recalled, was "to draw some attention to it" and then ask people to voice their concern. From this experience, Ross Perot started the "United We Stand" organization. 
Developing an Organization for Exposure of the POW and MIA Issue

Sybil Stockdale was convinced that Ross Perot "was working hand in glove with the Nixon administration" and that he was influential in obtaining President Nixon's support for the wives. The historical record is a bit more ambiguous on this point, however. It was clear from a number of White House memoranda that Ross Perot did speak with the President directly on his activities and issues related to POWs and MIAs. ${ }^{146}$ It is also clear that these talks resulted in certain actions.

For example, a memorandum from Nixon aide, Alexander Butterfield, summarized a meeting between President Nixon and Perot, which noted that, during the meeting; the President had been "reiterating his continued interest in resolving the POW dilemma." The memo also indicated that the President "felt that a separate team or organizations was needed, something independent of, or at least detached, from, the Department of State," and that these so-called action team approach "should serve to make the priority on this matter more clear. .. not only to the Hanoi Government and the U. S. Public, but our Departments of State and Defense as well." The memorandum also mentions Perot's strong conviction "that the action team system would certainly do more than is being done to relieve the plight of U. S. prisoners." The memo concluded by noting that President Nixon, by February 15, wanted "a game plan on how best to organize a White House team, the sole duty of which will be to work for" specific objectives. These objectives were as follows:

- impartial inspection of POW facilities

${ }^{146}$ Alexander Butterfield, Assistant Chief of Staff and Special Assistant to President Nixon, to Richard Nixon, President of the United States, Washington, DC, Jan. 31, 1970; Presidential Materials Project, Presidential Materials Review Board, Review on Contested Documents, White House Special Files; Staff Member and Office Files; Alexander P. Butterfield (Jan. 1970); Nixon Presidential Materials; National Archives at College Park, College Park, MD. 
- free exchange of mail and packages

- release of a list of names of all known prisoners

- the earliest possible release of all prisoners ${ }^{147}$

Given the State Department's well-established commitment to pursuing a strategy of Quiet Diplomacy - a commitment that did not simply disappear with the change of administrations - this decision during the Perot meeting to establish a White House team independent of the State Department could be considered as a significant move. Thus, the historical record at least partially supports Sybil Stockdale's assumptions about Ross Perot's influence within the White House.

My interview with presidential aide, Alexander Butterfield, however, suggests a somewhat contradictory—or at least a considerably more complex—story. Butterfield told me that Perot "was always more harm than he was good for us." He added that those in the White House actually "tried to distance [themselves] from the things Perot was doing." He went so far as to say, "We were scared to death of him."' Butterfield added that Perot was a "true loose cannon" and noted, "you can't have a Wildman attached to the President or to the White House or to the Department of State."

Butterfield did say, however, that Perot "is a very generous man, not a bad guy sitting around like this chewing the fat," and that "he's done some wonderfully generous

${ }^{147}$ Alexander P. Butterfield, Assistant Chief of Staff and Special Assistant to President Nixon, to The President's File, Washington, DC, February 1, 1970; President's Office Files; Memoranda for the President; Beginning January 4, 1970-May 31, 1970, February 1, 1970; Nixon Presidential Materials; National Archives at College Park, College Park, MD. Also located in Alexander P. Butterfield, Assistant Chief of Staff and Special Assistant to President Nixon, to The President's File, Washington, DC, February 1, 1970; White House Special Files; Staff Members and Office Files; Alexander B. Butterfield, Correspondence, File//January 1969 to June 1970; Nixon Presidential Materials; National Archives at College Park, College Park, MD. 
Developing an Organization for Exposure of the POW and MIA Issue things." ${ }^{148}$ He also noted that for "the wives he was very good ... very generous with his money ... his heart was in the right place." Thus, while his influence on the Nixon administration could be debated, his support for the National League and his assistance in spreading the League's message across to the nation is exceedingly clear. To this day, the wives I interviewed acknowledged and remained exceedingly grateful for this support.

\section{Senator Bob Dole}

Many of the wives who I interviewed also mentioned the support of Senator Robert Dole of Kansas and spoke of the work Senator Dole did to help them get the POW and MIA issue on the national agenda. Though Mr. Dole did not grant an interview, he sent me a number of important and pertinent documents related to his work on the POW and MIA issue. Richard Capen, Assistant Secretary of Defense during the Nixon administration, also provided information about Mr. Dole's contributions. Capen was the one who put the story of the significance of Dole's support in context. When I interviewed him, in fact, Capen spoke about his personal frustration with obtaining high ranking elected and appointed officials — even within the Nixon administration in which Capen served - to attend to the POW and MIA issue. "We couldn't get the interest of the Department of State. We couldn't get the interest of the White House. We couldn't get Kissinger's interest. They were all doing other things."

As in the Johnson administration, the "other things" dealt with ending the war. Capen said that whenever he and others raised the POW and MIA issue, the response,

148

At his own expense, Ross Perot chartered two airplanes for the express purposes of delivering 26 tons of food and Christmas presents to American prisoners in Hanoi in 1969. Though not successful, the act gained widespread media attention. 


\section{Chapter Six}

invariably, was, "We're not going to worry about this."

So Capen did an end-run of sorts, and attempted to use pressure from Congress to get the POW and MIA issue on the national agenda. An obvious point person for this effort would be World War II veteran, Senator Robert Dole (R-KS). Capen recalled telling Senator Dole that the POW and MIA situation not only was "an important issue" but that it also was an issue "right up [his] alley." Capen told me that "it was Bob Dole who took the issue" and ran with it, and many of the wives had similar recollections. Even Sandy Dennison, who was concerned that Senator Dole was overly hawkish on the war, acknowledged that his involvement with the POW and MIA issue was genuine and important.

Among the materials Senator Dole sent to me was his April 29, 1970, testimony before the house Foreign Affairs Committee, Subcommittee on National Security Policy and Scientific Developments. ${ }^{149}$ His statement to the committee acknowledged previous testimony and a plethora of documents that the committee had received that substantiated the "humiliation and abuse" of POWs and the "unpardonable manipulation of information" of North Vietnam. His statement also summarized how Congressional participation was taking a leading role to advocate for and demand humane treatment of POW, as well as a full accounting of MIAs. ${ }^{150}$

In his testimony, Dole also mentioned the National League of Families meeting that was scheduled to begin on May 2, 1970, and the designation of May 3 as a National Day of Prayer "for humane treatment and safe return of these brave Americans." ${ }^{151}$

\footnotetext{
${ }_{150}^{149}$ Senator Bob Dole, correspondence with author, March 28, 2003.

${ }_{151}$ Ibid. Ibid.
} 
Developing an Organization for Exposure of the POW and MIA Issue

Finally, Senator Dole mentioned a tribute to the POWs billed as: "Appeal for International Justice," scheduled for Constitutional Hall on May 1.

Senator Dole was instrumental in organizing the May 1 tribute. He did this after attending a similar sort of Constitutional Hall event several months earlier in February 1970. There were only 300 attendees at that earlier event in a venue that seats 3000 .

Because of the sparse turnout and support among colleagues, Senator Dole resolved to fill Constitution Hall in 90 days. $^{152}$ He accomplished this goal.

Ross Perot and Sybil Stockdale were named the honorary co-chairpersons of the May event, and Senator Dole was one of the speakers. In his correspondence to me, Mr. Dole included a copy of his opening remarks at the, "Appeal for International Justice" in Constitutional Hall. The speech is a clarion call for citizenry to become actively involved in the POW and MIA issue:

In Ancient Greece, a philosopher was once asked, "When will justice come to Athens?" He replied, "Justice will never come to Athens until those who are not injured start to become as indignant as those who are injured." Today we say that international justice will never come to Southeast Asia unless we who do not have loved ones missing or listed as Prisoners of War start to become as indignant as those who do. ${ }^{153}$

The Senator concluded his remarks by saying that being sympathetic to the prisoners and their families was insufficient. "We must organize," he said," to demonstrate continuing American concern for captured and missing American servicemen." Then laying down

${ }^{152}$ POW and MIA Tribute Day, $91^{\text {st }}$ Cong., $2^{\text {nd }}$ sess., Congressional Record 116 (March 12, 1970, to March 20, 1970): p. 8331. private collection.

Senator Bob Dole, Constitutional Hall, Washington, DC, May 1, 1970, unpublished data, 
Chapter Six

the gauntlet, he declared Americans "must mobilize the court of world opinion against these atrocities." ${ }^{154}$

Mr. Dole continued to bring the POW and MIA issue before the Senate, as attested by entries in the Congressional Record for May 20, 1970, July 20, 1971, and September 29, 1971. Also included in the packet of material Senator Dole sent to me was a copy of a personal letter he had sent to members of the House and Senate. In that letter, he requested that members of Congress offer their allocated seats to POW and MIA family members from their States to attend the Joint Session of Congress on September 22, 1970. At that time, Colonel Frank Borman would report on his eleven-nation trip in support of the POWs and MIAs. From these documents and other files from the National Archives, it is apparent that Mr. Dole was tireless in his efforts to gain support, publicity, and maintain pressure on North Vietnam for their violations of the Geneva Convention. Most of this was done without the public fanfare, which resulted in him never given the credit for his efforts. The wives I interviewed, however, knew about the external support Senator Dole provided their organization and their organization's agenda.

Other External Support: The National Advertising Council's Campaign

As has already been noted in the discussion of the national organization's finances, the National League also benefited from significant (but unsolicited) donations from a number of organizations. One organization that was mentioned as significant by a number of the wives I interviewed - and by Richard Capen and Alexander Butterfieldwas the Advertising Council. The Advertising Council is, as it was then, a private, nonprofit organization that produces public service announcements that addresses critical

${ }^{154}$ Ibid. 
Developing an Organization for Exposure of the POW and MIA Issue social issues to educate Americans and change public attitude. The Council made a major effort to publicize the plight of the prisoners, and a number of the wives, even decades later, continue to believe that this publicity was important in raising public awareness of the POW and MIA issue.

It is not clear what role, if any, the National League played in encouraging the Advertising Council's media blitz. What is clear was the role that President Nixon and members of his administration played in encouraging the Advertising Council's POW campaign. For instance, a March 22, 1971, White House memorandum from Alexander Butterfield to Brigadier General Hughes contains the subject line, "Full-Time PR Activities relative to the administration's efforts on behalf of POWs and those listed as MIA" and refers to a March 10 meeting between Mr. Robert Keim, President of Advertising Council, and the President. ${ }^{155}$ As the later section on the government's response to the POW issue, in general, and the National Leagues efforts, in particular, will make clear, the Advertising Council's POW campaign was part of a more general strategy within the Nixon administration to use the POW and MIA issue to address a number of diplomatic and political goals.

In discussions of the political process, however, intentions must be separated out from effects. Whatever intentions motivated the Advertising Council's campaign to increase public awareness of the POW issue; the wives who recalled the campaign were convinced that the campaign provided their cause invaluable support.

${ }^{155}$ The memo also refers to "other members of the ad hoc interagency group on POW's and MI's." Alexander P. Butterfield, Assistant Chief of Staff and Special Assistant to President Nixon, to Brigadier General James D. Hughes, Military Assistant to the President, Washington, DC, Mar. 22, 1971; Presidential Materials Review Board, Review on Contested Documents, White House Special Files; Staff Member and Office Files; Alexander P. Butterfield, (Mar. 1971); Nixon Presidential Materials; National Archives at College Park, College Park, MD. 


\section{Chapter Six}

Putting External Support in Context

What this section demonstrated was that the wives and family members did not work in isolation. Individuals such as Ross Perot and Senator Robert Dole and organizations such as the National Advertising Council became powerful and important allies, and they were, in fact, highly important in communicating the National League's message about the unjust and illegal treatment of the POWs.

This discussion of external support, however, should not be seen as, in any way, minimizing the importance of the wives' and family members' efforts to get the POW issue onto government officials' agenda and into the consciousness of the American People. The POW wives were out in front on the POW issue; they were publicizing the POW issue before any of their external allies embraced it. Even before a national organization had been formed, and long before Senator Dole attempted to rouse his colleagues and Ross Perot was attempting to influence President Nixon or the American public, the POW wives were making their personal visits and corresponding with government officials. As early as January 1969 soon after the telegraph-in discussed above, Sybil Stockdale wrote to President Nixon, in her leadership role in what was then the League of Wives, asking for a meeting with him. It took almost a year for that request to be granted - the meeting finally occurred on December 12,1969-but, during the intervening year, as the section on the government's response will clearly indicate, the administration was quite aware of the wives and the issue that they had raised.

Furthermore, even before the Advertising Council entered the picture, the wives had been working to generate publicity to, as Mary Winn said, "arouse the support of the American public" and have "local groups appeal to Congressman and Senators and 
Developing an Organization for Exposure of the POW and MIA Issue government officials." Over the years, the wives and the other family members who became part of the formal organization that had been formed became quite adept at doing publicity and applying pressure indirectly. In part, this was because of only the wives and family members had a truly compelling personal story to tell. Sybil, for instance, was convinced that if the reality of the POW and MIA issue failed to touch the publics' soul it would not spread; therefore, according to Sybil, "the idea was to involve everyone emotionally."

By the time Sybil Stockdale and a group of representative wives and mothers from, what had become, the National League of Families of American Prisoners in Southeast Asia met with President Nixon at the end of 1969, it was obvious that the group had achieved its goals of both obtaining the public's attention and placing the POW and MIA issue on government officials' radar screen. It was still not clear, at the time, however, whether or not the treatment of the prisoners had improved, nor was it clear that improvement would occur in the near future. Consequently, the National League adopted a new set of strategies that, in at least some significant respects, broke with the standard operating procedures that the group had used in the past: the group decided to become players on the world stage.

Bold Maneuvers: The National League Becomes a Player on the World Stage

"In 1972 I did go under the League umbrella to Paris for [the] International Communist Conference on Indo-China at Versailles. There were 800 communist delegates. . . three of us were chosen to go over. I represented all families in North Vietnam, one representing South Vietnam, and one from Laos." 
Chapter Six

Phyllis Galanti, Wife of POW

As with most other strategies employed by the National League, even what I have characterized in the heading for this section as the National League's "bold international maneuver," had been, in a sense, rehearsed on a more informal basis prior to the National League officially embracing and utilizing the strategy. Indeed, one-third of the wives I interviewed spoke of making a trip to Paris, to confront the North Vietnamese representatives to the Peace Talks. Many of these trips happened outside of the auspices of the League of Wives or the National League.

The first trip to Paris, in fact, occurred in September 1968 with a second one two months later in November. A local Dallas, Texas, television station, paid for the first trip and Ross Perot funded the second trip. The first trip included a delegation of four POW wives from Texas headed by Bonnie Singleton; the second trip included Bonnie and one other wife from the first trip. This group-like all the other groups that would follow them to Paris with and without the imprimatur of the League of Wives or the National League - had a clear agenda: they wanted information about their husbands and their questions about their husbands' situations answered. Furthermore, they wanted to confront the North Vietnamese about their mistreatment of the prisoners, violations of the Geneva Convention, and generate publicity about the plight of the prisoners.

Bonnie also told me that she and the others who accompanied her to Paris understood the need to remain independent of the United States government. While discussing this point with me, Bonnie recalled the advice of Murphy Martin, a local television personality in Dallas. According to Bonnie, Martin had told her that the wives were "best served by not affiliating with anyone but just going as yourselves—be yourselves." Bonnie told me that 
Developing an Organization for Exposure of the POW and MIA Issue she and the others "knew that the North Vietnamese would immediately claim [they] were pawns of the government and the military." Consequently, she--and most of the other wives I interviewed who had worked internationally-understood that keeping their distance from the United States government and eschewing official governmental sponsorship-would help them, in Bonnie's words, "have credibility in the world." ${ }^{156}$ Interestingly, Sybil Stockdale opposed the Texas delegation's trip. Bonnie recalled receiving a phone call from Sybil in 1968, while Bonnie was planning the Dallas-based wives' first trip to Paris. According to Bonnie, the major objection was that the group had not done its homework and, consequently, could do more harm than good.

During their telephone call, Sybil told Bonnie about a similar group of wives from California that was planning a similar group. Members of this group, however, were educating themselves about the cultural differences between Americans and Vietnamese before making the trip. Sybil believed that such knowledge was of vital importance so that the wives would not "make [the North Vietnamese officials] angry by embarrassing them." Bonnie told me that she "explained to [Sybil] that [the Dallas group] never thought about anybody not liking the idea or feeling like [they] were doing something wrong." Bonnie said, "It was an independent decision that [they] made," not an organizational one. She and her delegation went to Paris, and Sybil and Bonnie agreed to

${ }^{156}$ Some of the wives I interviewed did speak about receiving advice or guidance when they visited Paris. For instance, Bonnie Singleton recalled that before departing on their first trip Frank Sieverts, Department of State, told the women that they could not make it appear they had any connections with the American government. Furthermore, he told her that neither the Department of State nor the American government could be held "responsible for what might happen to you." On her second trip, Henry Cabot Lodge was in Paris and wanted to meet with her and the other wife before they went to the North Vietnamese Embassy. Because of her commitment not to be viewed as a patsy or entangled with American government interests she refused to meet with Lodge. Another instance was mentioned by Chloe Moore. She told me that prior to her and three other women departing America for Paris they were "debriefed" by governmental authorities and told not to discuss with anyone the status of their husbands as either POW or MIA. They could only talk in terms of: "My husband is in the service, he's overseas." 
Chapter Six

respectfully disagree on this point. The emphasis here is on the adverb respectfully. As with a number of other significant disagreements among members of the League of Wives and the two iterations of the National League, those who disagreed found ways to manage these disagreements and keep them from becoming personal and undermining the effectiveness of the group.

Other informal delegations followed Bonnie Singleton's lead in going to Paris before the strategy was officially embraced and employed by the national organization. Sybil's concerns about avoiding offending the North Vietnamese became a moot point during most of these early visits. From the women I interviewed it appeared that for sometime after meeting with Bonnie Singleton and her group the North Vietnamese delegates to Paris mostly ignored the wives who came to meet with them-often not even opening the door.

Chloe Moore, for instance, recalled feelings of desperation and frustration when she and a group of wives went to Paris and were denied any opportunity to speak with North Vietnamese officials. She told me, "We'd wait at the door [of the North Vietnamese embassy] and bang on the door. The French police would come and say to us; 'Leave right now, or we'll take you in.' They weren't very friendly. We were not successful."

Similarly, Marie Estocin's told me that during her first trip to Paris with Jenny Connell Robertson and their children, the North Vietnamese officials "slammed the door" in their face. Jenny told me that the experience "was very painful" for her and her children. On their second trip to Paris, during which their children once again accompanied them, Marie and Jenny were advised, and Marie did not remember by 
Developing an Organization for Exposure of the POW and MIA Issue whom, to have media personnel follow them to the North Vietnamese Embassy. Marie told me she remembered UPI camera crews and photographers at the Embassy and "shot the whole series of [them] pounding on the door and note getting a response." Marie told me the goal "was to prove to the American public that the Vietnamese were not cooperating with us as far as getting out information in a truthful way. UPI cameras shot that whole series and situation of us pounding on the door and not getting a response." Indeed, although the wives who went to Paris without the official support of the national organization were less than successful in getting access to the North Vietnamese, their trips were quite successful in generating publicity at home and abroad. Ross Perot and Congressman Olin Teague (D-TX), for example, had used their influence to ensure that the Dallas media covered Bonnie Singleton's first and second trip to Paris. And Jenny Connell Robertson recalled that the news media that covered their second attempt to speak to the North Vietnamese delegation in Paris photographed the children carrying pictures of their dads. If pictures are worth a thousand words, these pictures instantaneously told a truly compelling story.

This sort of human twist, along with the inherent drama associated with confrontation, ensured continued media interest in covering wives groups' attempts to talk with the North Vietnamese delegates, and the stories the media reported ensured global recognition of and continued worldwide publicity for the POW and MIA issue. The wives also traveled to neutral countries and, at times, were successful in arranging meetings with government officials in these countries. Bonnie Singleton, for example, told me of her meeting with Olof Palme, Prime Minister of Sweden. 
Chapter Six

Whether meeting with international leaders or talking with the international press, the wives' message was always the same. As Chloe Moore told me, the wives did not "request that they [the North Vietnamese] release our husbands . . that was futile." Rather the request was for information, humane treatment, adherence to the Geneva Convention Relative to the Treatment of Prisoners of War, and holding the North Vietnamese accountable for the men.

This focus on the need for humane treatment and the failure of the North Vietnamese to provide such treatment and adhere to the Geneva Convention served to embarrass the North Vietnamese, according to Bonnie Singleton. She noted that the North Vietnamese began to mount their own publicity campaign aimed at denying the wives' charges about prisoner mistreatment, which taught the wives an important lesson: "The North Vietnamese were responsive to the pressure of public opinion."

Sybil Stockdale first traveled to Paris in August 1969. She headed an official delegation representing the newly formed National League. Unlike most of the other wives who had been rebuffed in their attempts to talk with the North Vietnamese representatives in Paris, Sybil and her delegation were formally received by the North Vietnamese delegation. Presumably, this occurred, at least in part, because Sybil and her delegation were official representatives of national organization and because of Sybil's status as the National's League's founder and initial National Coordinator of the League of Wives and National League of Families. The decision by North Vietnamese officials to meet with Sybil and her delegation may also have been influenced by what appeared to be growing concerns among the North Vietnamese about negative POW publicity. 
Developing an Organization for Exposure of the POW and MIA Issue

At any rate, the meeting took place on October 4. After a few opening remarks, Xuan Oanh, head of the North Vietnamese delegation, pulled out the July 31, 1969 , edition of the New York Times that contained a story and a photo of her sitting on the steps of the Capital in Washington DC. According to Sybil, Xuan Oanh told her, "We know all about you Mrs. Stockdale .... We know you are the organizer" of the National League of Families. Sybil told me that her "heart just dropped" because she was "scared to death about what he was going to say" next. What else did he know, she wondered. What other issue was he about to raise? There was an extended period of silence, during which Sybil purposely refrained from speaking. She simply waited. After a time, the conversation turned to other matters, i.e., the issues that the National League had been raising for a number of years: mail delivery, Red Cross inspections, the North Vietnamese to provide a list of prisoners and account for the missing, and adhere to the Geneva Convention agreement about the treatment of prisoners. As the discussion began to cover very familiar ground (albeit with a very unfamiliar audience), Sybil told me, decades later, that she began to "feel a lot better." 
Chapter Seven: The United States Government Responds

"It's pretty hard for them [the wives] to do much if they don't feel the government wants them to do it. You're running a risk that you might in fact be jeopardizing lives, or, jeopardizing our ability to negotiate a settlement in Paris. How would you know?

If they're [government and military officials] telling you for five years you're going to endanger their life ... the Peace Talks . . embarrass the North Vietnamese ... it will prolong the war.

All those things could have happened when we did what we did.

But, we didn't think we had the luxury of doing nothing!"

\section{Richard Capen}

After nearly four decades, the wives I interviewed, who were part of the League of Wives or the National League of Families, remained uncertain — and some were downright skeptical—about the impact their group had had on the policymaking process. For instance, they were unaware - after all these years - if their work had any direct influence on elected or appointed officials in Washington DC. Most wanted to believe that they had made a difference, but many doubted that this was the case and all the women I interviewed were uncertain about the matter.

At a POW and MIA wives gathering in August 2004, I presented several White House documents to show them the extent of their influence. As the fourteen ladies viewed the sample documents, I listened to their comments to each other. It quickly became apparent that, for all of the wives, including the politically savvy leader of the group, Sybil Stockdale, this was the first time they had been informed of - much less seen-documents that focused on their efforts and the impact of these efforts on the 
The United States Government Responds

Nixon White House. The question put to me, again and again, was, "Do you think we really made a difference?" The data reported in this final section strongly supports the claim that the women's actions did, indeed, have a significant impact.

Precipitating Events to Influence Nixon White House

This section begins by discussing activities that the wives engaged in that have already been focused on in earlier sections. Here, however, the focus is on the government's reaction to these activities.

The League of Wives Telegraph-In

By the time of Richard Nixon's election as President in 1968, the National League activities, in Sybil Stockdale's words, had "really became refined in response to specific events." During my interview with Sybil, she talked about the late 1960 s and the number of protest conducted through "sit-ins" and "stand-ins" on college campuses and at governmental buildings across America. This effort on the part of anti-war and civil rights demonstrators gave her an idea. She decided the League of Wives would conduct a "telegraph-in" with the target being the Nixon White House.

Communicating with an estimated sixty wives across the country, which in turn communicated with other wives, Sybil asked the wives to send as many telegrams as possible to the newly elected President on Inauguration Day, January 20, 1969. According to Sybil, the message was simple; the wives were "asking him to give the prisoner situation a high priority in his administration." The result, she said, was over, "two thousand telegrams on his desk that day after his inauguration."

The Nixon White House files stored at the National Archives and Records Administration in College Park, Maryland contain actual telegrams sent to the White 


\section{Chapter Seven}

House. One such telegram, dated January 20, 1969, is from Mrs. Nell R. Peele of

Raleigh, North Carolina. Her request to the President is straightforward: "I ask today every effort be made on behalf of the prisoners who are utterly helpless without the intervention by you—our President — their Commander-in-Chief. My congratulations to you on this historic day; my prayers join those of millions for your immediate solution to our agony of suspense, as we await the release of our prisoners and the return of our sons and husbands."

The files also contain numerous letters and memoranda regarding the wives "telegraph-in." In a White House memorandum dated January 22, 1969, Gwen King, White House Staff and Correspondence, informed Bromley Smith, White House Staff, about the telegrams arriving for the President from families of prisoners of war in North Vietnam. She wrote:

Since noon January 20, 1969, 424 telegrams have been received from families of POW in NVN - and the telegraph office says they are continuing to come in. The theme is substantially the same: (a) that the President give top priority to obtaining the release of the prisoners of war (b) that the North Vietnamese supply a list of the prisoners of war (c) that the families be allowed to correspond with them, and (d) that no deals be made with the North Vietnamese in negotiation in Paris without including release of prisoners of war. ${ }^{158}$

${ }^{157}$ Mrs. Nell R. Pelle, to Richard Nixon, President of the United States, Raleigh, NC, January 20, 1969; White House Central Files ND 18-3; Prisoners; [1969-70]; Nixon Presidential Materials; National Archives, at College Park, College Park, MD.

Gwen King, White House Staff and Correspondence, to Bromley Smith, White House Staff, Washington, DC, January 22, 1969; White House Central Files ND 18-3/CO 165; Beginning; 12/31/69; Nixon Presidential Materials; National Archives at College Park, College Park, MD. 
The United States Government Responds

She also informed Smith that 393 telegrams "have been sent to the Department of State" and she wanted to know from Smith about routing procedures she should take for those continuing to arrive. ${ }^{159}$

As mentioned in Chapter 7, Sybil Stockdale had had the opportunity to speak with Alexander Butterfield, Assistant Chief of Staff, and Special Assistant to President Nixon, at a function in Coronado, California, where he discussed his experiences in the Nixon White House. She told me that they spoke about the telegraph-in and that from Butterfield's recollection the "two thousand telegrams on his desk really made a difference" and that they "had an effect on the President." Years later, during an interview with me for this study, Butterfield reiterated the belief that the telegrams that arrived on inauguration day certainly got the POW and MIA issue on Nixon's radar screen.

There is one other bit of, admittedly, circumstantial evidence that Butterfield's judgment about the impact of the telegram campaign is, indeed, correct. President Nixon conducted his first press conference, on January 27, 1969. During the press conference, when prompted by two different questions about ending the war, President Nixon said that certain steps "can be taken now ... [that] we believe the other side should agree to and can agree to." These steps included, as Nixon said, "the exchange of prisoners," something that, as has been noted, traditionally occurs only when a war has ended. ${ }^{160}$ It is difficult to definitively connect the dots between President Nixon's press conference endorsement of exchanging prisoners sooner rather than later, on the one hand, and the telegraph-in, on the other. Indeed, at the press conference, President Nixon

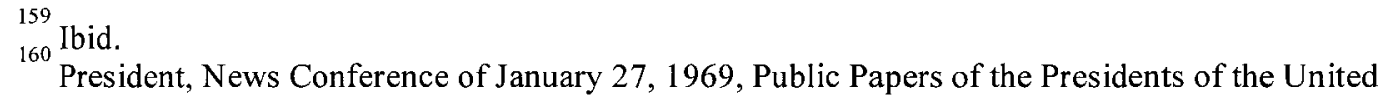
States, Richard Nixon, (1969): 10. 
Chapter Seven

clearly indicated that he was endorsing the recommendations for immediate action made by Ambassador to South Vietnam, Henry Cabot Lodge. Lodge's influence on Nixon's thinking also is confirmed in notes that Nixon made on ledger paper a week or so prior to the press conference: "V. Nam: Lodge statement—sets forth American position: (1) Mutual withdrawal - (2) D.M.Z. restoring - (3) Prisoner Exchange." 161

Even if Lodge was the prime catalyst, however, it is possible that the wives influenced Lodge's thinking. Bonnie Singleton mentioned corresponding with him and his request to meet with her. Bonnie, however, was about to embark on her second trip to Paris to confront the North Vietnamese delegation when Mr. Lodge wanted to meet. Consequently, she refused in order to maintain a sense of independence from government.

Sybil Stockdale indicated that she also had contacted Ambassador Lodge to inform him of a second telegraph-in two months after the group's first effort. The second telegraph-in was aimed, not at President Nixon, but at Xuan Thuy in Paris, Chief of the North Vietnamese Delegation to the Paris Peace Conference. ${ }^{162}$

Whether any of these contacts stimulated Ambassador Lodge's advice to the President on the POW issue cannot be known, at this point. Even if it did not, however, it seems reasonable to assume, in light of Butterfield's remarks about the White House's awareness of the thousands of telegrams that arrived on inauguration day, that the women's actions played at least some part in increasing the saliency of the POW and MIA issue within the Nixon administration. From the wives perspective, of course, the

${ }^{161}$ President's Handwriting, Washington, DC, January 20 and 21; White House Special Files, President's Office Files; White House Notes April 1969; Handwriting 1968-April 1969, January 1969; Nixon Presidential Materials; National Archives at College Park, College Park, MD. (See note 142.) 
The United States Government Responds important thing was the President of the United States, for whatever reason, mentioned the POW/MIA issue during his first press conference.

The League of Wives Official Request to Meet with Nixon

"I think we will prevail in our efforts to see the President personally."

$$
\text { Sybil Stockdale }
$$

Immediately after the wives telegraph-in, Sybil Stockdale sent a telegram dated January 23, 1969, to President Nixon requesting a meeting with him. In her telegram, Sybil informed President Nixon that she was asked by the League of Wives of American Prisoners in Vietnam "to represent them in asking for a brief visit." She requested that, if possible, the meeting be scheduled on either January 30 or 31 , which corresponded with the two days that she would be in Washington DC. ${ }^{163}$

As it turned out, this lone telegram by Sybil Stockdale initiated several internal White House, Department of Defense, and Department of State memoranda. In a letter dated January 29, 1969, Carl S. Wallace, Office of the Secretary of Defense, wrote to Colonel Hughes, Armed Forces Aide to the President, and discussed Sybil's request to meet with the President. Wallace's memorandum indicated that the Office of the Secretary of Defense and Department of State recommended the President see her, but in conjunction with other wives. Furthermore, Wallace wrote, if President Nixon were to meet with the women, the recommendation is that "no advance publicity of this meeting be given." The memorandum also included background information about Sybil Stockdale; Wallace characterized Sybil as an "articulate, forthright, and a vigorous leader among this group of women whose husbands are prisoners." (This is also the

${ }^{163}$ Sybil Stockdale, unpublished data, private collection. 


\section{Chapter Seven}

memorandum that characterized Sybil's personality as "intelligent, stable and articulate woman.")

On January 30, 1969, Colonel Hughes sent a memorandum to John D. Erlichman, Assistant to the President for Domestic Affairs about Sybil's request. The opening line of the memorandum is indicative of the amount of influence Sybil Stockdale and the wives had gained within the Department of Defense. Hughes wrote: "We have received some pressure from within the Department of Defense for a Mrs. James B. Stockdale to be received by the President in an official call." ${ }^{165}$ He also addressed additional matters, which, according to him, required serious consideration "if any meeting should take place and, if so, what form it should take; and who should be represented." 166

The Hughes memorandum is important for a number reasons. One reason is that it documents that the women had been successful in signing up allies within the Department of Defense. The memo also is important because it is the first official indication about the government's perception of the number of women involved with the League of Wives; the memo estimates the number as "fifty." The estimate is significant because it demonstrates that size does not necessarily matter when it comes to garnering political influence. Despite their small size, the wives had the power to generate a flurry of activity within the Nixon administration.

${ }^{164}$ Carl S. Wallace, Office of the Secretary of Defense, to Colonel James D. Hughes, Armed Forces Aide to the President, Washington, DC, January 29, 1969; White House Central Files ND 18-3/CO 165; Beginning; 12/31/69; Nixon Presidential Materials; National Archives at College Park, College Park, MD.

${ }^{165}$ Colonel James D. Hughes, Armed Forces Aide to the President, to John D. Erlichman, Assistant to the President for Domestic Affairs, Washington, DC, January 30, 1969; White House Central Files ND 18-3/CO 165; Beginning; 12/31/69; Nixon Presidential Materials; National Archives at College Park, College Park, MD.

${ }_{167}$ Ibid.

Ibid. 
The United States Government Responds

Just over three decades later, Richard Capen, during my interview with him, offered a somewhat different perspective about the size of the group relative to those advancing the cause; he noted that "there were a lot more members ... [but] there were relative small numbers who were really leading this effort." Even when less active and potential members are included in the count, the group could hardly be considered sizable. It is much more likely that the group got the White House's attention because of its cohesiveness and consistent message rather than the size of its membership.

Colonel Hughes responded to Sybil's request on January 31, 1969, and informed her that President Nixon could not meet with her due to "an extremely heavy schedule and post-transition workload." ${ }^{168}$ He reminded Sybil that at the President's first press conference and "from other public statements which he has made [the prisoners] are a matter of primary concern to him." ${ }^{169}$ The letter concluded with his assurances that the POWs "will not be forgotten here at the White House. They will be a matter of concern to the President and to all of us until they are safely returned to this country."170

On February 12, 1969, Sybil Stockdale sent a letter to Colonel Hughes at the White House in response to his January 31 letter. Its full contents demonstrate Sybil's determination, her continued commitment to the personal visit strategy for influencing public officials (even the President of the United States), and her developing political savvy which, in this instance, is demonstrated by her expressed intent to establish a broader and more representative political coalition prior to making a second request a

\footnotetext{
${ }^{168}$ Colonel James D. Hughes, Armed Forces Aide to the President, to Mrs. Sybil Stockdale, Washington, DC, January 31, 1969; White House Central Files ND 18-3/CO 165; ND 18-3, Beginning; 12/31/69; ${ }_{169}$ ixon Presidential Materials; National Archives at College Park, College Park, MD.

170 Ibid.

Ibid.
} 


\section{Chapter Seven}

meeting. (This last insight, of course, mirrored the recommendation in Wallace memorandum that the President should meet with other POW and MIA wives, not just Sybil. Sybil, of course, did not know about the Wallace recommendation.) Here is what Sybil wrote to Colonel Hughes:

Thank you for your very kind reply about my request to visit with the President. I am indeed glad that the military representatives at the White House are so aware of the POW's in Vietnam and any efforts which you exert to give their plight a high level priority consideration will be much appreciated. However, I think we will prevail in our efforts to see the President personally, as nothing (as I am sure you know) is as impressive as a personal visit. I will take heed from my recent experience, however, and will join forces with the other services having prisoners there when submitting my next request. I hope that we may meet soon and thank you for your past efforts in my behalf. ${ }^{171}$

After Sybil sent the above letter, the issue of a White House visit appears to have been closed. The National Archives, for instance, contains no letters or memoranda on this topic for a number of months after Sybil sent her letter to Colonel Hughes. Closure, however, was only temporary. As comments in Sybil's letter promise, the personal visit issue did, indeed, re-emerge later in the game as the women intensified their efforts to compel the United States government to take action on the POW and MIA issue. There will be more on these intensified efforts-including efforts to use the personal visit strategy with the President of the United States-in the later parts of this chapter.

${ }^{171}$ Mrs. Sybil Stockdale, to Colonel James D. Hughes, Armed Forces Aide to the President, Coronado, CA, February 12, 1969; White House Central Files ND 18-3/CO 165; Beginning; 12/31/69; Nixon Presidential Materials; National Archives at College Park, College Park, MD. 
Capital Hill Visits and the Congressional Record

"This fact, that the wives had been badgering members of Congress and that [their] activity started to appear in the news and television, kind of forced Nixon to finally see them and talk to them."

\section{Alexander Butterfield}

As was noted in previous sections, the wives extensively used their personal visit strategy on members of Congress. Over time, and as a result of these visits and the relationships and sensitivity to the POW and MIA issue that developed from them, statements were made on the floors of the House and Senate that demonstrated growing support in the legislative branch for the women and their cause. The Congressional Record of the era, in fact, documents mounting support on Capital Hill among Senators and Congressman, including members of President Nixon's political party.

Senator Hugh Scott (R-PA), echoed many of the National League themes regarding the plight of the prisoners, accountability of POWs and MIAs by Hanoi, lack of communication between prisoners and families, violations of the Geneva Convention, and even the accusation of possible murder. He stated: "We who have not suffered such a loss first hand must do more than wring our hands in sympathy. We must make this problem one of the highest possible priorities in our every contact with the Communist world. . . Until the day they are free, we Americans cannot rest. Our national conscience will not permit us to." ${ }^{172}$

The same day, Senator Charles Goodell (R-NY), referred to how the POW and

${ }^{172}$ Remarks: American Prisoners of North Vietnam, $91^{\text {st }}$ Cong., $2^{\text {nd }}$ sess., Congressional Record 116 (April 23, 1970, to May 4, 1970): p. 13850. 


\section{Chapter Seven}

MIA matter had gained unanimous support among Americans who demanded justice even though the war has created division in the country. Senator Goodell said, "Last year, I noted that among the many sad chapters to the history of the war in Vietnam, the most obnoxious chapter of all deals with the mistreatment of the POW's. This was true then. Sadly, the same is true today." ${ }^{173}$

Congressional support for the League and its cause did not only come from Republicans; rather, the evidence from the Congressional Record suggests that interest in the POW and MIA issue and support for the National League was bipartisan. Senator William Proxmire (D-WI), for instance, used time on the Senate floor to request support for Republican Senator Robert Dole's Constitutional Hall tribute scheduled for May 1970. Like other elected leaders, Republicans and Democrats, his speech echoed the themes of the National League before appealing to the Nixon administration for "a determined commitment" on the POW and MIA matter. That commitment, he said, "cannot live on rhetoric alone. It is time to reaffirm that commitment by action: action in serious negotiations through the Read Cross, the United Nations, and other international organizations; action to get other nations to intervene in our behalf for the prisoners of war; and action by individual citizens working through local groups." ${ }^{174}$

There is other evidence, beyond the formal speeches recorded in the Congressional Record, to demonstrate that the members of the National League had become, over the years, exceedingly influential with members of Congress. Sybil's correspondence file from the era, for example, contains a letter to her from Congressman

\footnotetext{
${ }_{174}^{173}$ Ibid., Remarks: Appeal for International Justice on POWS. p. 13875. Ibid., Remarks: Serious Commitment Needed to Help Prisoners of War-Rally at Constitutional Hall. p. 13876.
} 
The United States Government Responds

Olin Teague (D-TX). In the letter, Congressman Teague indicates that he had heard about a "newsletter" Sybil Stockdale was developing for wives and family members of POWs and MIAs. He wrote: "I do not know whether or not the Congressional Record can be used for a medium of exchange; but if you think so, just let me know." ${ }^{175}$

The Congressional Record turned out to be an ill-suited venue for publishing a newsletter written for wives of POWs and MIAs, and issues of the newsletter, consequently, never were published in the Congressional Record. Congressman Teague's offer to attempt to do this, however, illustrates the sort of relationships the women had established with certain members of the legislative branch by the start of the Nixon administration.

\footnotetext{
${ }^{175}$ From Congressman Olin Teague (D-TX) to Mrs. James Stockdale, February 3, 1967. Sybil Stockdale, unpublished data, private collection.
} 


\section{Chapter Seven}

A Defining Moment: Secretary of Defense Melvin Laird Goes Public and Shift's the

\section{Government's POW and MIA Policy}

"I had a responsibility to them."

Melving Laird, Secretary of Defense

"Once Melvin Laird did that [the public announcement] it became a National 'Okay." My God, you couldn't keep'em from jumping on."

Sybil Stockdale

One of the members of Congress the wives visited during the Johnson administration was a nine-term congressman from Wisconsin, Melvin Laird. As the ranking Republican on the Defense Appropriation Subcommittee, he knew a lot about Defense issues. He had also been President Nixon's defense advisor during the presidential campaign.

When Richard Nixon became President, he tapped Congressman Laird to be his Secretary of Defense. This meant that the National League had at least one exceedingly influential "friend" within the Nixon administration. Laird, in fact, used his influence in a number of ways to support the goals of the National League. His actions and influenced are discussed below.

Melvin Laird: The Reluctant Secretary of Defense

Richard Capen, an Assistant Secretary of Defense in the Nixon administration, told me during an interview, that Melvin Laird had "reluctantly agreed to become Secretary of Defense" (emphasis added). Capen also told me that Melvin Laird established two ground rules before accepting the appointment. First, "he would pick his own people." This was because, as Richard Capen said, Melvin Laird did not "want any 
The United States Government Responds

political cast offs, or IOUs, or some governor who had lost and needed to have a job" working for him. The second ground rule was just as definitive: "If anybody in the White House had a reason to contact the Department of Defense, they had to contact him [Melvin Laird] and it [i.e., the person initiating the contact] had to either be the President or Kissinger. No one else was allowed to contact people down the line and cause problems and confusion in the Department of Defense."

These conditions, which the President, obviously agreed to, meant that the National League's friend in the executive branch of government was, indeed, powerful, even more powerful than the typical Secretary of Defense would be. Laird quickly used his power to make the POW and MIA matter as a salient political issue within the administration.

Richard Capen: A Second Ally in the Department of Defense

Another of the National League's allies within the upper echelon of the Nixon Department of Defense, Assistant Secretary of Defense for Public Affairs Richard Capen. Capen was not only a competent ally but also an essential sounding board for Laird on the POW and MIA issue, which eventually led to the reversal of the previous administration's policy of Quiet Diplomacy. ${ }^{176}$

During my interview with Capen, he recalled that, during Melvin Laird's first meeting with the Assistant Secretaries of Defense, the group reviewed the first of many casualty reports from the war. According to Capen, the reported "number was 502 killed." With great emphasis, he told me, "I will never forget that number! All of the sudden it was our war and those are our killed" (emphasis added).

${ }^{176}$ Capen's later post was Assistant Secretary of Defense for Legislative Affairs. 
Chapter Seven

Handling the POW and MIA issue was also now their responsibility — or at least they would make it the Department of Defense's responsibility even though the Department of State had been responsible within the Johnson administration. Capen told me that, early in the Nixon administration, "it was hard to get anybody's attention [on the POW and MIA issue] because there were so many more huge issues involved at this point." According to Capen, the issues included the ABM treaty (antiballistic missile), the war in Vietnam, and then the issue on Capital Hill to "limit the President's flexibility" to conduct the war. This already full agenda meant that any proposal for the government to become more proactive on POW and MIA matters competed with a plethora of other as geopolitical and domestic issues already on the administration's plate.

Still, at the start of the Nixon presidency, Melvin Laird's staff reviewed the POW and MIA issue and the prior administration's approach to it. Capen was already familiar with the issue because he had lived in San Diego, California, before accepting the Assistant Secretary post in the Department of Defense. Consequently, he was aware of the personal impact of the POW and MIA issue on wives and families, as well as family members' views of the existing policy and the government's rationale for it. Decades later, during my interview with him, Capen referred to the POW and MIA issue as "a huge cloud of pressure hanging over everybody, including the government [on] how to treat this issue and save lives." He also indicated that he knew that maintaining the previous administration's Quiet Diplomacy-Keep Quiet policy on the POW and MIA issue would result in a revolt by the POW and MIA family members.

Based on his experience and knowledge, he decided to speak with Laird about the status of the POW and MIA issue, but not before, he had additional evidence to show 
The United States Government Responds

Laird. The evidence included all the photographs the Department of Defense had gathered through intelligence and other means, including photographs and films of the POWs paraded through the streets of Hanoi. When he completed his review and compiled his data, he went to Laird and said: "Mel, I don't think we can afford to keep quiet anymore. We know they're being tortured. We know they're not getting letters. We know they're not getting medical care. We know some of them are dying in captivity. We've got some famous pictures; including the one of John McCain." ${ }^{177}$

Capen's advice to Laird was unequivocal: Capen told me he told the Secretary of Defense, "We have an obligation to go public. We cannot take the chance that any more men are going to die. We're going to have to take the chance that by putting the heat on we will cause the enemy to treat the men better."

As it turned out, the Secretary agreed. As Capen later told me: "We didn't think we had the luxury of doing nothing." Laird, himself, during my interview with him as part of this study, characterized President Johnson's Quiet Diplomacy strategy a "do nothing policy" because it did not address the plight of the POWs nor seek to change the conditions for the men.

\section{Laird's Publicly Announces a Change in POW and MIA Policy}

So, at a press conference in the Pentagon on May 19, 1969-which not so coincidentally, was the birthday of Ho Chi Minh, the President of North Vietnam, and a day of celebration for the North Vietnamese-Secretary of Defense Laird spoke to the

${ }^{177}$ Richard Capen told me that Melvin Laird asked him, as a courtesy, to show Admiral John McCain II, Command-in-Chief of Pacific Forces, all the photographic evidence they obtained on his son John and the pending decision to go public about the abuse and maltreatment of the prisoners. Capen said Admiral McCain committed himself to the decision and told Capen he would: "Help sell it with the POW and MIA families." 


\section{Chapter Seven}

American public and the world about the plight of the POWs and his concerns over MIAs. Strongly critical of North Vietnamese government he said:

I am deeply shocked and disappointed by this cruel response of Hanoi's representative to such a basic request for humanitarian action. Hundreds of American wives, children, and parents continue to live in a tragic state of uncertainty caused by the lack of information concerning the fate of their loved ones. This needless anxiety is caused by the persistent refusal by North Vietnam to release the names of U.S. prisoners of war.

I want to reaffirm the continuing hope that Hanoi will provide a list of American prisoners and permit a free flow of mail between U.S. prisoners of war and their families. We continue to urge the immediate release of sick and wounded prisoners, the neutral inspection of prisoner of war facilities, and the prompt release of all American prisoners. ${ }^{178}$

These comments (and others in a DOD News Release) signaled, clearly and unequivocally, an end to the government's so-called Keep Quiet policy. Interestingly, during my interview with Laird, he confirmed that the "the public announcement [about the shift in policy] was not approved by Richard Nixon or Henry Kissinger." He did not ask for approval, he told me, because Kissinger opposed any public discussion by administration officials about the plight of the POWs because he was concerned about Hanoi's diplomatic response and possible repercussions on his secret negotiation track. Richard Capen, who characterized the shift in policy that Laird announced at his

${ }^{178}$ Mr. Melvin Laird, Secretary of Defense, to Press Conference, Washington, DC, May 19, 1969; Melvin R. Laird Papers; Laird Public Statements (Bound); 3/27/69 - 6/20/69; Department of Defense Papers; Gerald R. Ford Library, Ann Arbor, MI. 
May 19 press conference "a big moment for [the POW] issue," told me that the announcement was "a huge risk on Melvin Laird's part." "People were pretty unhappy" with his decision, Capen told me. He recalled hearing comments like: the "Secretary of Defense - he's gone off and created all this thing and we don't have the diplomatic strategy behind it. . . . We don't know where it's headed. . . . We don't have any control over it." Capen also articulated another complaint he heard during this time: "We've got all these women who are calling on members of Congress, they're having their meetings, they're going to the White House."

Capen did acknowledge that the strategy that he had urged Laird to implement was, indeed, "high-risk stuff." In retrospect, however, he is certain that, despite the negative comments of many government officials at the time, the decision to go public about violations of the Geneva Convention and the inhumane treatment "made a huge difference."

Capen did complain that Laird "never received the credit" for his action on reversing the Quiet Diplomacy policy nor for the initiatives he undertook on the POW and MIA issue. "Everyone was getting the credit [for the eventual success of the POW and MIA efforts], including the liberals," he told me; "but so what; that's life!"

Among the wives of the POWs, however, Laird's efforts were noted and very much appreciated. As was indicated in an earlier section, the wives recognized —and continue to recognize - the contributions he made, including his decision to reverse what was, for them, the Keep Quiet Policy And Laird, himself, even today, is clear about his motives. During my interview with him, Laird indicated that he decided to circumvent Kissinger (and, also, in effect, the President) because he saw his primary responsibility, 


\section{Chapter Seven}

as Secretary of Defense, as being to the American servicemen held captive in Hanoi: "I had a responsibility to them - the military men," (emphasis added), he said. He went on to explain that this sense of responsibility came, in part, from having read the prisoners coded letters, taking note of the lack of information made available to the International Red Cross, and the wives stories! $!^{179}$

\section{The Washington Road Show Rolls Again!}

Richard Capen told me he immediately realized the announcement of the policy shift would create confusion among the families. Military casualty officers, he noted, had constantly reminded families not speak to anyone about their situation. Furthermore, Capen was aware that officials within the Department of State and Defense had been telling the wives that, if they spoke out, they "might endanger the lives of men" or jeopardize the government's "ability to negotiate a settlement in Paris." With the government now going public on the inhumane treatment, the families-Capen surmised - would have legitimate questions about the effect on their husbands or sons.

In fact, the women that I interviewed for this study had concluded that the government's Quiet Diplomacy policy was dysfunctional long before the Secretary of Defense's announcement of its demise. Long before Laird made his announcement, in fact, Sybil Stockdale had led the fight to obtain a change in the policy. Because of these efforts, Sybil received a courtesy phone call from Richard Capen (Department of Defense) and Frank Sieverts (Department of State) on the morning of May 19. As Sybil told me, she recalled that Capen told her, "At ten o'clock this morning, Washington time, Melvin Laird, Secretary of Defense, is going to stand up and acknowledge the fact

${ }^{179}$ The Honorable Melvin R. Laird, correspondence with author, May 22 and June 14, 2003. 
The United States Government Responds

publicly that our prisoners are not being treated humanely." Sybil she said the announcement was a "major, major, major victory." She hastened to tell me, somewhat somberly, that, by then; her husband "had been in prison four years."

Of course, it is certainly possible - and even likely - that not every wife shared Sybil's views about the Quiet Diplomacy policy. As Capen noted, the wives were not a "monolithic group of women." Thus, it was probably appropriate that Laird and Capen decided it was necessary to bring POW and MIA families up-to-date on the Department of Defense's POW and MIA policy and what going public would mean in terms of the government's overall POW/MIA strategy. At any rate, in the summer of 1969, the decision from May 19 was translated into a new series of briefings for families. Or, to use the wives' words, there was a new Washington Road Shows coming to town.

As was noted in a previous section, the perceptions of the wives I interviewed with respect to the new round of briefings was conditioned, at least somewhat, by their experience with prior performances by government officials. Even today, many remain critical of what they saw and heard. Some of the women, however, did detect some differences between the government briefings before and after the Laird announcement.

Jenny Connell Robertson, for instance, told me that, after the announcement, government and military officials "seemed to listen to [the wives] more intently and more seriously ... and $\operatorname{tr}[\mathrm{ied}]$ to answer some of our questions." During the previous administration, she told me, Washington Road Shows were nothing more than a series of speeches; when the women spoke "they [government officials] didn't listen . . . they wanted us to sit and listen." After Laird's announcement of the government's change in 


\section{Chapter Seven}

policy and his willingness to speak publicly about the mistreatment of the POWs, the "response was definitely different."

\section{So, What Did the Wives Play in Laird's Decision to Reverse the Quiet Diplomacy Policy}

It is always difficult to attribute a shift in policy to the actions of a particular group of individuals or to a particular set of strategies. Comments by Richard Capen suggest that this is certainly the case due to Laird's decision to reverse the government's policy of Quiet Diplomacy, as well as with other governmental actions that flowed from this policy reversal. In my interview with Capen, he acknowledged the wives "worked hard" to bring about the government's public acknowledgment of inhumane treatment and to hold North Vietnam accountable for the prisoners and of those missing. He told me, however, that the wives did not save "the lives of their husbands single-handedly. It just doesn't' work that way." Rather, "an issue like this," according to Capen, "grows much beyond any one person or one department." Indeed, in one sense, he said, the POW and MIA issue was not the "driving force behind the overall effort to end, to win, or resolve the war in Vietnam." He added, however, that the POW and MIA issue "was a part of it." Clearly, the wives actions helped make the POW and MIA issue "a part of it"; their actions kept the issue front and center in discourse and debate about what to do about the Vietnam War.

Capen, in fact, characterized the relationship between the Department of Defense and the wives and their formal organization as a partnership, albeit a partnership with self-imposed limitations. "It would have been inappropriate to team up per se because the beauty of this was it was independent," Capen told me. According to Capen, it was functional for both parties to maintain a degree of separation between the National 
The United States Government Responds League and a government agency and between the leaders of the National League and government officials. Because of this separation—or, according to Capen, because of itthe wives, in Capen's words, "played a very important, a very strong supportive role" (emphasis added).

Maintaining this supportive role and the influence that went with it while also remaining separate and independent could not have been easy. Comments that Secretary of Defense Melvin Laird made in 1981 during an interview with Vernon E. Davis, Consultant for the Historical Office in the Office of the Secretary of Defense, suggest the wisdom of the League's conscious decision to remain focused on the POW and MIA issue and to remain nonpartisan on other aspects of the war. In a "Memorandum for the Record," Davis summarized a comment Melvin Laird made about the National League as follows: "The impression Mr. Melvin Laird retained of the National League of Families was that its members, especially its leadership, had consistently supported Department of Defense policies. In particular, they had defended Vietnamization after others had become critical of it" ${ }^{180}$

In fact, there was considerable disagreement within the organization about the administration's Vietnam policies. In deciding to sidestep such issues at the organizational level, however, the National League transformed itself into the organizational equivalent of a Rorschach test. As noted earlier, the decision not to take sides on the larger Vietnam War questions helped promote group cohesion as well as ensured that the League would have a consistent and highly focused message. Laird's

\footnotetext{
${ }^{180}$ Memorandum for the Record by Vernon E. Davis, April 10, 1981, Office of the Secretary of Defense, OSD Historical Office.
} 


\section{Chapter Seven}

comments suggest that the strategy also helped maintain the League's fragile partnership with the Department of Defense and, in so doing, maintain League members' access to those with power and their ability to influence the issue that was their central concern. The organization's nonpartisan stance, of course, also did not alienated the dovish critics of the administration, many of whom also supported the League.

Nixon White House Activity on POW and MIA Wives Meeting

"We had a hell-of-a-time getting Kissinger to meet with [the wives] - they didn't want to meet with Kissinger. They wanted to meet with the President."

\section{Richard Capen}

As part of the research, I considered it critically important to locate official White House documents to determine — as best as possible — what any impact that the League's actions had on the Nixon White House, not just the Department of Defense. This research took place at National Archives and Records Administration (NARA) in College Park, Maryland.

The amount of relevant material housed at the National Archives is enormous. I ended up reviewing about seventy-five boxes of materials related specifically to POW and MIA issues. These boxes contained letters, notes, and memoranda related to POW and MIA issues within the Nixon administration. A typical box contains approximately 1,000 pages of material; some of the boxes I examined contained less than this amount.

Of the tens-of-thousands of pages I reviewed, approximately 350 pages were deemed sufficiently relevant to my research topic to make copies for analysis. Systematically analyzing even this number of pages was a daunting task. I must note, however, that thousands of documents remain unread while others remain classified by 
the government and are not releasable to the public-unless a researcher submits a "Mandatory Review Request" form. I submitted such forms; at the Department of Defense, which enabled me to have two classified documents from the Office of the Secretary of Defense declassified. ${ }^{181}$ At the National Archives, however, I could not get approval in a timely manner, possibly because all such requests also required approval from attorneys for the Nixon estate. Even within the boxes of materials to which I had access, often I discovered a "Document Withdrawal Record" form, which indicated materials had been removed from the box for national security reasons or because of privacy issues.

Despite the access problems, I learned that some members of the White Staff had a greater level of involvement in POW and MIA matters than other members did. One of those who the records indicated was heavily involved with the issue was Alexander Butterfield, the presidential aide who, during the Watergate hearings, revealed that the Oval Office had a taping system. I contacted Butterfield, and he agreed to be interviewed. He also commented on a number of memos he had authored that I had discovered in the National Archives.

Butterfield turned out to be a man who possessed - and was willing to share - a unique insider perspective of how the Nixon White House operated, in general, and the White House's treatment of the POW and MIA issue, in particular. Consequently,

\footnotetext{
${ }^{181}$ I made an attempt to listen to one White House Oval Office audio tape, which the NARA White House tape logs indicated Oval Office discussions related to POW and MIA matters. Within the Nixon Presidential Materials at NARA, the catalogue of tapes lists 312 audio tape reference numbers that contain conversations related to POW and MIA matters. Due to the deplorable audio quality I could not be confident in my ability to correctly decipher conversations. However, once the audio tapes are professionally remastered and transcribed, the conversations would be invaluable for additional research on POW and MIA matters.
} 


\section{Chapter Seven}

interview data was used to supplement information gleaned from National Archives documents in attempting to connect any dots that existed between the wives' actions and the administration's shifts in policy.

During my interview with him, I soon realized that this was a public figure of uncharacteristic candor. Without being braggadocios, he told me his relationship with President Nixon was akin to a "personal aide [doing] many things for Richard Nixon on a personal level." Before becoming part of the White House staff, Butterfield had retired from the United States Air Force. Because he had been a Squadron Commander in Vietnam, as well a career officer, he knew some of the prisoners in Hanoi. Also, having been raised in Coronado, California, a naval aviation town, many of his friends were graduates of the Naval Academy who later flew in the Navy or Marine Corps. A number of these pilots had been shot down and imprisoned. He spoke to me about this unusual twist of fate and said, "I had friends in prison, and, suddenly, there I was in the White House."

Butterfield also told me that many of the POW and MIA wives - through their communication network-had learned that he was working in the White House. Their hope, he said, was that he "would be able to pick up their cause and be one of their representatives ... in the White House." He told me that he did end up playing this quasirole, though "in a completely unofficial capacity." He added that he was "not necessarily the White House's point man, although maybe in the eyes of some [he] came to be that" but he "wasn't designated by Nixon" to deal with the POW and MIA issue, however. 
White House Considers Plans for POW and MIA Wives to Meet with the President

As has been noted in a number of places already, Sybil Stockdale considered personal visits one of the most effective ways of influencing public officials. At the outset of this section, a failed attempt to arrange a meeting with the President was discussed. It was also noted that Sybil "did not take no for an answer" and made it clear that she would make another request for a meeting in the near future. Several months later, she did just that.

The archival material I reviewed indicated that the second request created a flurry of activity and memo writing among the White House staff. The staff may have preferred to ignore the POW and MIA matter, as Capen had noted, but Mrs. Stockdale's request to discuss the matter with the President required some sort of response. White House staff members disagreed about what that response should be.

A key actor, of course, was Alexander Butterfield. Butterfield drafted a memorandum for the President titled: "A Plan to Counter Assertions of an Ineffective Vietnam Policy." This memo outlined a number of arguments that could be used to counter false assertions about Nixon's Vietnam policy. Under a separate cover, Butterfield attached a document to the memorandum titled: "Game Plan for The President's Pursuit for Peace Speech." Item number 46 of the memo highlighted the fact that the POW issue could now benefit the President and suggested that the administration "plan for bringing to Washington a representative group of POW wives for call on the President-mid December." ${ }^{182}$

${ }^{182}$ Alexander P. Butterfield, Assistant Chief of Staff and Special Assistant to President Nixon, to Richard Nixon, President of the United States, Washington, DC, September 23, 1969; White House Special Files; Staff Members and Office Files; Alexander B. Butterfield, Correspondence, File January 1969 to June 1970; Nixon Presidential Materials; National Archives at College Park, College Park, MD. 


\section{Chapter Seven}

A couple of days after Alexander Butterfield sent his memorandum to the

President, Melvin Laird also sent a memorandum to the President. Dated September 25, 1969, this memorandum appealed directly for the President to intervene and meet with POW and MIA wives. In making his case, Laird explained his own actions during the May 19, 1969 press conference discussed previously. He told the President that he had acted out of a "deep concern for the welfare of our captured and missing servicemen, together with my concern for the inhumane attitude on prisoner matters by the North Vietnamese and the Viet Cong." He also assured the President that he had taken action only after "a thorough review of the problem." ${ }^{183}$

Finally, the Laird memo noted that "an increasing number" of prisoner's relatives have contacted "government officials, members of Congress and the news media." Wives and parents, he told the Nixon, were requesting, via his office, a meeting with the President. He recommended to the President that a representative group of twenty family members of POWs and MIAs meet in the White House. The meeting, Laird wrote, would also provide the President with an opportunity to express his personal concern and indicate concern for the matter at highest level of government. ${ }^{184}$

Internal White House's Debate over the Proposed Visit

By September 27, 1969, the idea of the President meeting with the wives was gaining momentum in the White House. In a memorandum from Colonel Hughes to Stephen Bull, Special Assistant to the President and Appointments Secretary, it appeared Bull had requested Hughes' assistance to set up an appointment with "two wives."

${ }^{183}$ Mr. Melvin Laird, Secretary of Defense, to Richard Nixon, President of the United States, Washington, DC, September 25, 1969; White House Central Files, ND 18-3/CO 165; Beginning; 12/31/69; Nixon Pressidential Materials; National Archives at College Park, College Park, MD. Ibid. 
Hughes' memo referred to the memorandum "just received" by the President from Melvin Laird. Colonel Hughes informed Bull that he considered the wives meeting with President Nixon appropriate, but recommended one wife from each branch of service rather than the plans stipulated in either the Bull or the Laird memos. Hughes also recommended scheduling the meeting in conjunction with a church service after which the President would speak with the wives. In his mind, the meeting would have a "much better public impact if it were done in this manner." He added that whatever decision was made about the number of people who should attend; those who attended needed to be "carefully screened for emotional stability and judgment." ${ }^{185}$

Other archived memos indicate that not all members of the White House staff supported the meeting. The memo writers articulated a number of reasons for opposing the meeting. One reason echoed Colonel Hughes' concern about the emotional stability of those who would attend the meeting. In a memo Bryce Harlow sent to another White House staff member, Hugh Sloan, Jr., Harlow indicated that he was "much afraid of a personal meeting of these distraught women with the President." Unlike Hughes, Harlow did not appear to believe that the potential problems that might arise from the President meeting with what he believed were emotionally distraught women could be managed by simply increasing the number of women in attendance. ${ }^{186}$

A far more compelling and influential reason for not scheduling the meeting was

185

Colonel James D. Hughes, Armed Forces Aide to the President, to Stephen Bull, Special Assistant to the President and Appointments Secretary, Washington, DC, September 27, 1969; White House Central Files, ND 18-3 CO/165; Beginning; 12/31/69; Nixon Presidential Materials; National Archives at College Park, College Park, MD.

Bryce Harlow, Presidential Counselor and Adviser, to Hugh Sloan, Staff Assistant to the President, Washington, DC, October 6, 1969; White House Central Files, ND 18-3 CO/165; Beginning; 12/31/69; Nixon Presidential Materials; National Archives at College Park, College Park, MD. 


\section{Chapter Seven}

put forth by Henry Kissinger who, at the time was Assistant to the President for National

Security Affairs. In a memo to the President to the President dated October 2, 1969 ,

Kissinger first acknowledged the President's concern about the POW and MIA matter. He then wrote the following: "There is some tenuous evidence that Hanoi, on the defensive from our demands for an accounting of our prisoners, has shifted its policy somewhat and may be willing to provide the families, privately, with information on their loved ones' status. Thus, we have taken a careful hands-off policy with regard to the wives, lest we jeopardize their chances of learning the facts about their husbands." Kissinger concluded his memo as follows: "Because of this, I would recommend that you do not meet with any of the wives involved." 187

There is evidence that the President attended to and, with some reluctance, decided to heed Kissinger's advice, at least for a while. I found another copy of the Kissinger memo in the White House file box, for example, and beside Kissinger's punchline ("I would recommend that you do not meet with any of the wives involved.") there is the following handwritten note: "but let's reexamine each week RN." 188

I also discovered the following short memorandum from Dwight Chapin, the President's Appointment Secretary, to H. R. Haldeman that presumably had the Kissinger memo attached: "Here is what Kissinger said - - - let me know if this should be reopened.

\footnotetext{
187

Dr. Henry A. Kissinger, Assistant to the President for National Security Affairs, to Richard Nixon, President of the United States, Washington, DC, October 2, 1969; White House Central Files, ND 18-3 CO/165; Beginning; 12/31/69; Nixon Presidential Materials; National Archives at College Park, College Park, MD.

Dr. Henry A. Kissinger, Assistant to the President for National Security Affairs, to Richard Nixon, President of the United States, Washington, DC, October 2, 1969; President's Office Files, President's Handwriting; September 1969-November 1969; File Box October 1 thru 15, 1969; Nixon Presidential Materials; National Archives at College Park, College Park, MD.
} 
It is now off the schedule." Haldeman response was a handwritten note on the memo:

"No-leave it off. H."

There are a number of other indications that the Kissinger argument had garnered widespread support among White House staff members and that there was a growing consensus within the staff against scheduling a meeting. I discovered a memo from Colonel Haig to Hugh Sloan dated October 8, 1969, in which Haig referred to a "paper on Mr. Kissinger's desk." Their position, Haig told Sloan, was based on the "pitfalls of associating them [the wives and family members] officially with the US Government and thus providing an excuse for the North Vietnamese not to be responsive to their requests for the names of prisoners. ${ }^{190}$ Haig noted that if Kissinger's recommendation was approved, there would - in all probability — not be a meeting between the President and the wives.

The following day, October 9, Colonel Haig sent a memorandum to Dwight Chapin, who evidently requested "Henry's opinion" on inviting POW and MIA wives to meet with the President. Colonel Haig states:

Henry is opposed to an official White House appearance of POW wives until such time as we are sure that private initiatives made by some of them in Paris will reap no benefit. Official government linkage with these women at this time could be used as a basis by Hanoi for refusal to give the wives the names of their loved ones.

189

Dwight Chapin, President's Appointment Secretary, to Bob Haldeman, Assistant to the President/Chief of Staff, Washington, DC, October 6, 1969; White House Central Files, ND 18-3 CO/165; Beginning: 12/31/69; Nixon Presidential Materials; National Archives at College Park, College Park, MD.

Al Haig, Senior Military Assistant to the President, to Hugh Sloan, Staff Assistant to the President, Washington, DC, October 8, 1969; White House Central Files, ND 18-3 CO/165; Beginning; 12/31/69; Nixon Presidential Materials; National Archives at College Park, College Park, MD. 


\section{Chapter Seven}

We should let the situation run until we are convinced that Hanoi has not responded to their requests and then make an official overture in behalf of the wives, including a visit to the White House. ${ }^{191}$

There was also a handwritten note, presumably written by Dwight Chapin, on the copy of the Haig memorandum that I reviewed. The note stated: "Ask Henry every week if change. $\mathrm{C}^{192}$

Colonel Haig's memo to Chapin also included one other element that I found in a number of other memoranda, which discussed the White House visit. Haig proposed an alternative to the White House meeting, which seemed, in his mind, to offset concerns expressed by other staff. His specific alternative would have had the wives meeting with the recently returned prisoners. "A visit of this type would be of far more benefit at this time," Haig wrote. ${ }^{193}$

Other White House staffers recommended other alternatives. There were recommendations to send the wives to Paris, to have the various service auxiliary organizations (e.g., the Veterans of Foreign War and the American Legion) meet with the wives and respond to their needs, or invite the wives to attend a worship service in the White House in lieu of holding a formal meeting. ${ }^{194}$

191

Al Haig, Senior Military Assistant to the President, to Dwight Chapin, President's Appointment Secretary, Washington, DC, October 9, 1969; White House Central Files, ND 18-3 CO/165; Beginning; 12/31/69; Nixon Presidential Materials; National Archives at College Park, College Park, MD.

${ }_{193}$ Ibid.

194 Ibid.

Bryce Harlow, Presidential Counselor and Adviser, to Hugh Sloan, Staff Assistant to the President, Washington, DC, October 6, 1969; White House Central Files, ND 18-3 CO/165; Beginning; 12/31/69; Nixon Presidential Materials; National Archives at College Park, College Park, MD. The church service idea is located in: Colonel James D. Hughes, Armed Forces Aide to the President, to Stephen Bull, Special Assistant to the President and Appointments Secretary, Washington, DC, September 27, 1969; White House Central Files, ND 18-3 CO/165; Beginning; 12/31/69; Nixon Presidential Materials; National Archives at College Park, College Park, MD. 
The United States Government Responds

A not-so-subtle subtext in many of the memos-and, at times, a memo's explicit text—involved domestic political considerations. For example, Alexander Haig wrote in a memo to Dwight Chapin: "We have again taken the temperature on the pros and cons" of the President hosting the wives for a personal visit. We still recommend against the President becoming involved at this time." Haig cited two reasons for such a position. The first reason was familiar: Hanoi will view wives as "propaganda agents of U.S. Government." The second reason also was familiar, but it normally was implicit rather than explicitly stated in staff memos: The visit, Haig said, would in effect, "add another page to the book of those who claim this is the President's war."

Domestic political considerations also could be used to support the idea of the wives meeting with the President. For example, in a memorandum to the President's Chief of Staff, H. R. Haldeman, dated October 20, 1969, Harry S. Dent, Deputy Counsel and Special Counsel to the President, indicated that he recently had seen news reports about the POW wives. He wrote:

Here are some more POW wives speaking out for the President. A White House visit by some POW wives would be a big plus on this question. These ladies have the sympathy of just about everybody these days. ${ }^{195}$

Others in the White House must have seen the same news reports that Dent alluded to in his memo to Haldeman. On October 17, 1969, Dwight Chapin wrote the following to Alexander Haig:

${ }^{195}$ Harry S. Dent, Deputy Counsel and Special Counsel to the President, to Bob Haldeman, Assistant to the President/Chief of Staff, Washington, DC, October 20, 1969; White House Central Files, ND 18-3 CO/165; Beginning; 12/31/69; Nixon Presidential Materials; National Archives at College Park, College Park, MD. 


\section{Chapter Seven}

The President had asked us to check with Henry each week in regard to his visiting with the prisoner of war wives. You undoubtedly saw last evening's $\underline{S t a r}$ and noted the comment from Hanoi that in order for the ladies to get their husbands out of the POW camps they would have to demonstrate against the United States. The women indicated that they would never demonstrate against the government for it would only dishonor their husbands.

The question now is whether or not the President should meet with the ladies at this time. Would you please check Henry? Thank you. ${ }^{196}$

The flurry of activity in the White House on this issue seemed to be generated in part, and possibly to a large degree, by Sybil Stockdale's two written requests, Melvin Laird's intercession, and pressure from Representatives and Senators on the Hill. In the end, it appears as if this confluence of factors led to the decision to schedule a White House meeting.

The Meeting is on and Planning for it Begins

At some point during the Fall of 1969 , the decision was made to have a representative group of POW and MIA wives and family members meet with the President. Who, within the White House, made the final decision, how it was made, and what reasoning led to the decision remain unanswered questions. Possibly, the answers to these questions will some day be found in one or more of the boxes of documents from the Nixon White House that I was unable to examine for this study, or from interviews for future study.

${ }^{196}$ Dwight Chapin, President's Appointment Secretary, to Colonel Al Haig, Senior Military Assistant to the President, Washington, DC, October 17, 1969; White House Central Files, ND 18-3 CO/165; Beginning; 12/31/69; Nixon Presidential Materials; National Archives at College Park, College Park, MD. 
What was clear in the materials I was able to review, however, was that the final details for the visit were being worked out in early December 1969. The files, for instance, include a memo from Richard Capen to Colonel Hughes dated December 3, 1969. The memo contains a suggested letter of invitation, comments on who was to be invited and the noticeable under-representation of some groups (e.g., families of enlisted men, fathers, and certain geographical areas/congressional districts), and a list of Department of Defense past initiatives to keep the wives and family members informed. $^{197}$

Capen's memo also cautioned that, while the families would appreciate the meeting, they, nonetheless, would possibly pose difficult questions for the President to address. To prepare the President for a possible interrogation, Capen provided Colonel Hughes with a list of questions the Department of Defense had been asked on many occasions by family members along with suggested answers to these questions. ${ }^{198}$

Capen concluded his memo with the following recommendations: (a) the President should speak to the media after the meeting, (b) a social meeting with Mrs. Nixon should be scheduled, and (c) a Department of Defense dinner should be scheduled for the night following the family members' meeting with the President. The purpose of the dinner, Capen wrote, was in order "to brief the families on the status of [the Department of Defense's] efforts to resolve the prisoner problem." ${ }^{199}$

${ }^{197}$ Richard G. Capen, Jr., Deputy Assistant Secretary, to Colonel James D. Hughes, Military Assistant to the President, Washington, DC, December 3, 1969; White House Central Files, ND18-3/CO 165; Beginning; 12/31/69; Nixon Presidential Materials; National Archives at College Park, College Park, MD.

$$
\begin{aligned}
& 198 \text { Ibid. } \\
& \text { Ibid. }
\end{aligned}
$$




\section{Chapter Seven}

In a memorandum dated December 4,1969 , one day after the date on the Capen memo, Alexander Butterfield indicated to Colonel Hughes that the date for the meeting with the President had been set; that date, according to Butterfield, was December 12 , 1969. Butterfield also discussed the Capen memo to Colonel Hughes and the material that Capen's office had included with the memo. Among other things, Butterfield expressed his concern about the "representation" issue raised in the Capen memo and suggested that "at least 1 , and preferably 2 more enlisted men [be] represented" by their family members. $^{200}$

In his memorandum, Butterfield also expressed his concern about the three wives scheduled to speak after the President made his official remarks. Butterfield advised Hughes: "I personally would prefer that none of the women speak to the press [but that] they merely stand by the President while he speaks." Once the President has completed his comments, he wrote, the women would depart the Roosevelt Room with him. ${ }^{201}$

Butterfield expressed specific concerns about one of the wives scheduled to address the press; that woman was Sybil Stockdale. "She has expressed in the past her great disappointment over what she terms a lack of concern on the part of the President," Butterfield wrote, "and in a recent phone call to me she sounded almost bitter." ${ }^{202}$

200

Alexander Butterfield, Assistant Chief of Staff and Special Assistant to President Nixon, to Colonel James D. Hughes, Military Assistant to the President, Washington, DC, December 4, 1969; White House Central Files, ND 18-3/CO165; Beginning; 12/31/69; Nixon Presidential Materials; National Archives at College Park, College Park, MD. Butterfield's memorandum also noted that wives and mothers were coming from California, Florida, Virginia, and Washington. This is explained, in part, due to the concentration of military bases in those States, where most of the wives lived while their husbands were either $\mathrm{PO}_{2} \mathrm{~W}$ or MIA.

${ }_{202}$ Ibid.

Alexander Butterfield, Assistant Chief of Staff and Special Assistant to President Nixon, to Colonel James D. Hughes, Military Assistant to the President, Washington, DC, December 4, 1969; White House Central Files, ND 18-3/CO165; Beginning; 12/31/69; Nixon Presidential Materials; National Archives at College Park, College Park, MD. 
The United States Government Responds

In another memo dated December 5, 1969, and sent to Special Assistant to the President, Stephen Bull, Butterfield discussed ways to create a "warmer and a little more personal" invitation telegram to the wives and family members. The memorandum discussed the wisdom of using of such terms as "plight," "predicament," and "tragic situation" to characterize the things that would be discussed during the meeting with the President. $^{203}$

A briefing document, written for the President to prepare him for the meeting with the wives and family members, was part of the Butterfield memo. The briefing document was titled: "Talking Paper for the President: Meeting with Families of Captured and Missing Serviceman," dated December 12, 1969, the day of the President's meeting with family members. The contents of the briefing paper indicate that at least some of the advice contained in Richard Capen's December 3 memo to Colonel Hughes had been heeded. Included in the briefing paper, for example, are questions the President might be asked during his meeting with family members along with suggested answers. The briefing document also informed the President that prisoners still were not receiving mail on a regular basis and that MIA wives "do not even know if their loved ones are alive." In his briefing paper, Butterfield also told the President that the women "have

${ }^{203}$ Alexander Butterfield, Assistant Chief of Staff and Special Assistant to President Nixon, to Stephen Bull, Special Assistant to the President and Appointments Secretary, Washington, DC, December 5, 1969; White House Central Files, ND 18-3 CO/165; Beginning; 12/31/69; Nixon Presidential Materials; National Archives at College Park, College Park, MD.

Alexander Butterfield, Assistant Chief of Staff and Special Assistant to President Nixon, to Richard Nixon, President of the United States, Washington, DC, December 12, 1969; White House Central Files, ND 18-3 CO/165; Beginning; 12/31/69; Nixon Presidential Materials; National Archives at College Park, College Park, MD. Also located in: Alexander Butterfield, Assistant Chief of Staff and Special Assistant to the President, to Richard Nixon, President of the United States, Washington, DC, December 12, 1969; White House Special Files; Staff Members and Office Files; Alexander B. Butterfield, Correspondence, File//January 1969 to June 1970//; Nixon Presidential Materials; National Archives at College Park, College Park, MD. 


\section{Chapter Seven}

carried on with dignity and respect for the cause for which their loved ones were

fighting." The paper encouraged the President to discuss with the women the support and actions taken by various governmental agencies-including the White House. And, he advised the President to provide families with assurance that the POW and MIA matters have the "highest priority both in our negotiations with the enemy and in all our domestic and diplomatic efforts." ${ }^{205}$

On the day of the meeting, December 12 , Alexander Butterfield also provided President Nixon with a "Fact Sheet" on POW and MIA matters. The Fact Sheet contains various data: 418 men listed as captured, 939 listed as missing, governmental initiatives and activities, acknowledgement of the wives painful experiences, and the wives concerns about the men being abandoned by the government. Alexander Butterfield underlined one point that he clearly wanted to draw attention to in the document:

All of these ladies - and their families - are anxious for your personal support, and for your assurance that there is hope. They want more than anything to know that you are continuing to assign this matter the highest priority . . . both in our negotiations with the enemy and in our domestic and diplomatic efforts. ${ }^{206}$

Within the Fact Sheet package Butterfield sent the President, he included a paper titled: "Corrected answer to one of the Questions which might be asked today during your meeting with POW wives and mothers." The question dealt with why it took so long for the wives to obtain an appointment with the President. The response focused on the claim

${ }_{206}^{205}$ Ibid.

Alexander Butterfield, Assistant Chief of Staff and Special Assistant to the President, to Richard Nixon, President of the United States, Washington, DC, December 12, 1969; White House Special Files; Staff Members and Office Files; Alexander B. Butterfield, Correspondence, File//January 1969 to June 1970//; Nixon Presidential Materials; National Archives at College Park, College Park, MD. 
that the POW and MIA issue was a "two-edged sword." The concern, as echoed by

Kissinger and others, was "that Hanoi might take reprisals against our captured men if we were to publicize their plight."

Prior to my interview with Alexander Butterfield, I mailed him copies of a number of documents he had written including both the "Talking Paper" and "Fact Sheet" he drafted to prepare the President for his meeting with the wives and family members. During our interview, and in written comments he sent to me, Butterfield noted that both documents were designed to do more than simply transmit information to the President. In fact, he told me that both documents were designed to encourage some spark in the President, to impress upon him that his message to the wives will be publicized, far and wide, and that he must convince them that every appropriate agency of the federal government will be working non-stop for the release of the prisoners and for a detailed accounting of those missing. He related the following to me:

The memo was for him, to bolster him, to remind him of the fact that this was an opportunity for him to shine. They are all appeals to the President to make his assurances to the ladies loud, clear and convincing. We, the aides, at Defense, State, the NSC [National Security Council] and the WH [White House] Staff are simply advising and guiding a President who, therefore, had not been on top of the POW and MIA issue at all.

207

Alexander Butterfield, Assistant Chief of Staff and Special Assistant to President Nixon, to Richard Nixon, President of the United States, Washington, DC, December 12, 1969; White House Central Files, ND 18-3 CO/165; Beginning; 12/31/69; Nixon Presidential Materials; National Archives at College Park, College Park, MD. Also in: Alexander Butterfield, Assistant Chief of Staff and Special Assistant to the President, to Richard Nixon, President of the United States, Washington, DC, December 12, 1969; White House Special Files; Staff Members and Office Files; Alexander B. Butterfield, Correspondence, File//January 1969 to June 1970//; Nixon Presidential Materials; National Archives at College Park, College Park, MD. 


\section{Chapter Seven}

President Nixon Meets with POW and MIA Wives and Mothers

The meeting between a select group of wives and mothers of POW and MIAs and President Nixon (as well as Mrs. Nixon) took place in the Library of the White House on December 12, 1969. President Nixon's daily dairy for that date noted that the meeting started at 10:06 a.m. and concluded at 10:30 a.m. During the Press Conference that followed the White House meeting, President Nixon made the following statement:

Insofar as the treatment of prisoners is concerned, it would probably not be inaccurate to say that the record in this war is one of the most unconscionable in the history of warfare. And there have been, of course, some very bad examples in past wars, as we know it. What I have assured these very courageous women, is that first, that in reaching a settlement of the war, that an integral part of any settlement that is agreed to must be a settlement which is satisfactory on the prisoner issue and second, ... this Government will do everything that it possibly can to separate out the prisoner issue and have it handled as it should be, as a separate issue on a humane basis.

Finally, I would simply add that while we all know that there is disagreement in this country about the war in Vietnam and while there is dissent about it on several points, that on this issue, the treatment of prisoners of war, that there can be and there should be no disagreement. ${ }^{208}$

After the meeting with the wives and family members, Nixon went to his office

President, Remarks following a meeting with wives and mothers of Prisoners of War and servicemen Missing in Action in Vietnam, December 12, 1969, Public Papers of the Presidents of the United States, Richard Nixon, (1969): 484. 
and met with H. R. Haldeman from 11:01 a.m. to 11:08 a.m. ${ }^{209}$ Later that day, both

President Nixon and H. R. Haldeman made diary entries regarding the meeting with the wives and mothers of POWs and MIAs. Nixon wrote in his Memoirs:

During the Christmas season of 1969 Pat and I met with twenty-six wives and mothers of POWs and MIAs. ... we listened to them tell of the effect of the years of waiting on them and their children, and the terrible uncertainty of not knowing whether their men were alive or dead. From that time on, each POW was an individual to me, and obtaining their release became a burning cause. ${ }^{210}$

In his diary, Haldeman clearly indicated the impression that the meeting had made on the President. He wrote:

Another breakfast-this time McCormack and Albert. Then a meeting w/ POW wives - who really impressed the P. He now has a great interest - amazing what a little personal exposure will do. He now wants all sorts of action. All this got AM sched pretty screwed up \& had to jiggle balance of appts. P. pretty upset that we let it get screwed up. ${ }^{211}$

A week and a half after the event, President Nixon, responded to a letter from Mrs. Abbott, a POW wife who attended the December 12 meeting. He wrote, "Seldom have I been so moved as I was during our recent meeting at the White House." He then complimented her and said, "This indomitable courage which you and the other valiant

${ }^{209}$ President Richard Nixon's Daily Dairy, The White House, Washington, DC, December 2, 1969; Nixon Presidential Materials Staff; White House Central Files; Staff Member and Office Files; Office of Presidential Papers and Archives (OPPA): Daily Diary, November 1, 1969 to March 31, 1970; Nixon Presidential Materials; National Archives at College Park, College Park, MD.

${ }_{211}$ Nixon, RN: Memoirs Richard Nixon, 859.

211 Handwritten Journals and Diaries of Harry Robbins Haldeman, December 12, 1969; January 18, 1969-December 2, 1970; Harry Robbins Haldeman Vol. III; September 23, 1969-January 12, 1970; Nixon Presidential Materials; National Archives at College Park, College Park, MD. 


\section{Chapter Seven}

women in your group demonstrated is a source of profound inspiration to all of us who had the honor of being with you." ${ }^{212}$

Alexander Butterfield's recollections of the day provide context for Nixon's reaction and suggest the wisdom of Sybil Stockdale's continued embracing of the personal visit strategy. During my interview with him, Butterfield told me that President "Nixon went to that meeting fairly kicking and screaming. It was an event he did not want to do, yet one he felt he must do." Butterfield then began reading and simultaneously commenting on a response he had written to one of the questions I had sent to him about the December 12 meeting before the interview:

He [Nixon] didn't want any part of it. It was a big pain in the neck. Meet with a bunch of women? He looked at it like that. I mean we're interested in the prisoner thing ... it was in the news about these wives being up there [on Capital Hill] and talking to a Senator who might have been very sentimental toward their cause and might have responded with, "Have you talked to the President yet?" He was sort of forced into seeing them. It helped my cause a little bit. I can't take credit reminding him everyday that he should do this. Anyway, when it looked like a plan in motion and he might do it-he still didn't want to. I said in here somewhere he went kicking and screaming to that meeting. That's in the privacy of the Oval Office when no one is in there, just Haldeman or myself.

I'm not saying he said, "Oh the hell with those women!" He has big things going on! High priority political things going on! He was going to wind this war down, get the ABM treaty - that was the first big thing on the Hill. He cared ${ }^{212}$ Richard Nixon, President of the United States, to Mrs. Abbott, December 22, 1969, 
The United States Government Responds about the ABM treaty more than anything. . . Then, once with them [POW and MIA wives], he got into it. They invigorated him. . . once he got in a meeting he knows what he needs to do. But it was great for both sides. That is what gave him the impetus to do what he did.

Throughout the interview, Butterfield continued to emphasize that the influence the wives had on the President from the December 12 meeting "was major." He indicated that the wives and family members were a "major influence" on Nixon and Nixon's policies and he credited "the wives one hundred percent for arousing the President's interest—for getting him off the dime." The meeting, in short, got the POW and MIA issue on the White House's radar screen. Among other things, this meant that the White House staff began monitoring media reports on the POWs and MIAs, as well as the public's response to the reports.

\section{White House Monitors Effect of Meeting}

On December 15, three days after the meeting with the wives and mothers, Alexander Butterfield sent a memorandum to the President about his meeting with the wives and mothers. He told the President, "As you know by now, your meeting last Friday with wives and mothers of captured and missing U.S. servicemen received very good play nationwide." Furthermore, he attached a personal letter from Sybil Stockdale, who, he said, "was absolutely overwhelmed," and was highly appreciative for the "words of assurance that resolution of the plight of the prisoners and missing persons will be

Washington, DC; White House Central Files, ND 18-3/CO 165; Beginning; 12/31/69; Nixon Presidential Materials; National Archives at College Park, College Park, MD. 


\section{Chapter Seven}

given the highest priority. ${ }^{213}$ During our interview, Butterfield discussed this

memorandum and the "very good play nationwide" of the December 12 meeting. In the

process of telling me this, he once again provided important contextual information about

how the Nixon White House operated:

We, several of us on the staff, monitored very carefully, what news played on

each major network and for how long — down to the second. We also monitored

the one hundred largest newspapers - so we know when something we did played

well. This event did, indeed. And I do remember that the President was very

pleased and said so.

On the same day that Butterfield sent his memo containing his comments on the success of the White House meeting, he also responded to the President's request for a very detailed "summary of past, present and future activities relating to resolution of the plight of captured and missing U. S. servicemen ... and their families." The report, ten pages in length, reviewed initiatives by the government, private citizens (Six of the ten pages detailed activity by Ross Perot), corporations, civic groups, clubs, and professional organizations to support "some guarantee of humane treatment and accounting of those persons now listed as missing." On the report the President noted, "Good job." He also wrote "good" next to the section that discussed Fairchild-Hiller Corporation's "full-page advertisements" designed to "focus attention on the prisoner problem."

213

Alexander Butterfield, Assistant Chief of Staff and Special Assistant to President Nixon, to Richard Nixon, President of the United States, Washington, DC, December 15, 1969; White House Special Files; Staff Members and Office Files; Alexander B. Butterfield, Correspondence, File//January 1969 to June 1970/4; Nixon Presidential Materials; National Archives at College Park, College Park, MD. Alexander Butterfield, Assistant Chief of Staff and Special Assistant to President Nixon, Richard Nixon, President of the United States, Washington, DC, December 15, 1969; President's Office Files; President's; December 1969 - January 15, 1969; Nixon Presidential Materials; National Archives at College Park, College Park, MD. Also in: White House Central Files, ND 18-3/CO 165; Beginning; 12/31/69; Nixon Presidential Materials; National Archives at College Park, College Park, MD. 


\section{White House Motivations}

Some of the White House memoranda I reviewed and copied referred to President Nixon's "continued," "steadfast," or "special" interest to resolve the POW and MIA dilemma. After reviewing these documents, Alexander Butterfield told me he really did not think it was "all that 'continued' or 'steadfast."' However, he quickly added, "it is true that the meeting on December 12 got him [Nixon] 'into the issue' and he'd mention it now and then." He also claimed "the POW and MIA priority-especially in '69 and '70could not compare with issues the President considered much more politically important. In the back of the President's mind, it was always a matter of politics." Alexander emphasized, as he had earlier, that Nixon ultimately viewed events with a political eye.

When I asked Butterfield why the President decided to actively address and become involved in the plight of prisoners and support the wives of POWs and MIAs, he bluntly stated: "Politics, politics!" Butterfield told me that he considered "that little, if any, of the President's motivation was for prisoners as individuals or as husbands." In spite of that, however, he said, "Nixon was a caring soul and he had thoughts and feelings like everyone else." Nevertheless, Butterfield emphasized yet again that the President's "political considerations - 'Will this be a good move politically?' - trumped all others."

In my correspondence with Al Haig, Jr. regarding the same question about Nixon's motives on the POW and MIA issue, he clearly indicated the President's motivation came from a moral imperative and not of political necessity. Haig provided the following statement:

Having worked personally with the President, Henry Kissinger and those on the National Security Staff as well as many legislative leaders, there is no doubt in 


\section{Chapter Seven}

my mind that the moral imperative predominated throughout. From my perspective, many war opponents endeavored to seize the issue as one of political expediency. $^{215}$

The interviews and archive material indicate that White House staff, quite naturally, viewed events, activities, and actions of the President from different perspectives. Whatever Nixon's motives may have been-humanitarian, political, or some complex amalgam of the two- he and his administration did attend to the POW and MIA after December 12, 1969, much more than they had before the President's December 12 meeting with the wives and family members. The issue, in fact, was front and center in the negotiations to end the war, despite the precedent that the prisoner issue traditionally is handled after a peace settlement has been reached.

\section{Nixon White House POW and MIA Initiatives}

From Alexander Butterfield perspective, at least, Nixon was, at base, "a political animal." Whether his comments after the meeting were simply a temporary foray into the sentimental or whether they were sincere and sustained over time cannot be determined. What the evidence does make clear, however, is that, after his meeting with the wives and family members, Nixon and his administration used the POW and MIA issue to support the administration's political agenda.

\section{White House Develops Propaganda Offensive for POW and MIA Issue}

As was noted above, political and propaganda considerations were hardly absent from the internal debate about whether or not the President should meet with a representative group of family members. In fact, the archives contain many memos about

${ }^{215}$ General Al Haig, Jr., correspondence with author, April 29, 2003 
The United States Government Responds

the administration's propaganda offensive against North Vietnam, and the POW and MIA issue often played a prominent role in the strategies that memo writers proposed.

Three months before the President's December 12 meeting with the wives and family members, for example, Ken Cole raised the POW and MIA issue in a memo to Bob Haldeman. The memo was precipitated by a summary story Nixon read in an internal White House media memorandum. In his memo, Cole told Haldeman that the:

President noted the report regarding the wives of the captive pilots and the POWs who came forward and told their stories of ill treatments and how these stories helped to keep the Administration on the propaganda offensive, painting the

North Vietnamese into the corner of inhumane obstructionists of peace.

Cole also reminded Haldeman that the President had said he wanted more of this type of media attention and to possibly have one or two wives come to the White House, which would expose the issue even more. ${ }^{216}$

Bob Haldeman, in turn, informed three White House officials-Henry Kissinger, Herbert Klein, Director of Communications for the Executive Branch, and Ronald Ziegler, White House Press Secretary - about the story Nixon saw regarding POW wives. Haldeman told them that the President "feels this is the sort of propaganda offensive that we need to keep generating toward the Vietnamese. Would you please follow up in generating more stories of this type?" Haldeman also told the three men that Nixon wanted a report, within three days, for a proposed plan of action on a propaganda campaign. $^{217}$

${ }^{216}$ Ken Cole, White House Aide, to Bob Haldeman, Assistant to the President/Chief of Staff, Washington, DC, September 22, 1969; White House Central Files, ND 18-3 CO/165; Beginning; 12/31/69; Nixon Pressidential Materials; National Archives at College Park, College Park, MD.

Bob Haldeman, Assistant to the President/Chief of Staff, to Dr. Henry Kissinger, Assistant to 


\section{Chapter Seven}

Haldeman sent another memo to Dwight Chapin that directed him, Ron Ziegler, and Alexander Butterfield to develop a "game plan" for handling the White House visit of two wives that had tentatively been agreed to at that time. ${ }^{218}$ (By the time the visit actually took place, of course, the initial two wives had grown to twenty-six wives and family members.) Haldeman made clear that the major focus of the game plan was to be on how to use the visit to support the President's desire for propaganda offensives against the North Vietnamese. A secondary strategy was for the President to convey sincere concern about the POW and MIA situation.

On September 24, 1969, two days before the Chapin/Ziegler/Butterfield "game plan" was due to the President, Ken Cole upped the ante, a bit, by sending, in essence, the same directive that Haldeman had sent. This time, however, the request for a document that responded to the "President's request for a plan of action to generate a propaganda offensive toward the Vietnamese" was sent not only to Ziegler, who was also mentioned in the Haldeman memo, but also to Kissinger and Klein. The Cole memo also specified a time by which the memo was to be delivered to Nixon's staff secretary: 2:00 p.m. on the date that had also been stipulated in Haldeman's memo to Chapin; September 26, 1969.

I did not find a copy of the requested report in the archived material I reviewed. I could not determine whether this is because it was not included in the material I reviewed, whether the report was written but never archived (either intentionally or

\footnotetext{
the President for National Security Affairs, Herbert Klein, Director of Communications for the Executive Branch, and Ronald Ziegler, White House Press Secretary, Washington, DC, September 23, 1969; White House Central Files, ND 18-3 CO/165; Beginning; 12/31/69; Nixon Presidential Materials; National Archives, at College Park, College Park, MD.

Bob Haldeman, Assistant to the President/Chief of Staff, to Dwight Chapin, President's Appointment Secretary, Washington, DC, September 23, 1969; White House Central Files, ND 18-3 CO/165; Beginning; 12/31/69; Nixon Presidential Materials; National Archives at College Park, College Park, MD.
} 
unintentionally), whether the report, for some reason, was never prepared, or whether it is classified. What I did find, however, was a memo Henry Kissinger sent to the President dated six days after the deadline for the report both Haldeman and Cole had requested. The memo summarized the administration's "POW Policy in Vietnam," and, among other things, discussed the President's goal to develop and sustain a POW and MIA propaganda offense against North Vietnam. Kissinger summarized the past activities of the Department of State and Department of Defense in the POW and MIA matter, and indicated that both departments "are attempting to use every appropriate forum possible to keep the heat on." Kissinger added: "There is some tenuous evidence that Hanoi, on the defensive from our demands for an accounting of our prisoners, has shifted its policy somewhat and may be willing to provide the families, privately, with information on their loved ones' status." ${ }^{219}$

Six days prior to the wives and family members meeting with the President, the propaganda offensive was discussed again, this time a memo sent by John Brown III, White House Staff Assistant of H. R. Haldeman to Alexander Butterfield. In the memo, dated December 6, 1969, Brown referred to a December 2 article in the Christian Science Monitor about "North Vietnam showing itself to be acutely sensitive to charges that it has ill-treated US POWs."

Even though the administration had initiated a propaganda campaign focused, in part at least on the POW issue months earlier, Brown informed Butterfield the President 219

${ }^{19}$ Dr. Henry A. Kissinger, Assistant to the President for National Security Affairs, to Richard Nixon, President of the United States, Washington, DC, October 2, 1969; White House Central Files, ND 18-3 CO/165; Beginning; 12/31/69; Nixon Presidential Materials; National Archives at College Park, College Park, MD.

John Brown III, White House staff assistant of H. R. Haldeman, to Alexander Butterfield, Assistant Chief of Staff and Special Assistant to President Nixon, Washington, DC, December 6, 1969; 


\section{Chapter Seven}

now wanted "a massive campaign" because it was now apparent that Hanoi was noticing the international attention the POW issue was receiving. Specifically, Brown told Butterfield: "The President requests that we initiate a massive campaign on the inhumane treatment of US POWs by Hanoi" and that "you [Butterfield] submit the report to him on what is planned." ${ }^{221}$ As he had done on other occasions, Ken Cole wrote a more formal, "White House Action Memorandum," which repeated the request contained in the more informal, less weighty memo from Brown. ${ }^{222}$

During my interview with Alexander Butterfield, he confirmed that the POW and MIA issue, indeed, had been the key element in a concerted effort to embarrass Hanoi on the world stage while simultaneously bring pressure on the Communist government of North Vietnam to change their treatment of the prisoners. "There was ammunition to embarrass Hanoi on an international scale," Butterfield said; "it was to Hanoi's disadvantage if we [i.e., the Nixon White House] could beat that drum around." Butterfield added, however, that, at the start of campaign, "nothing had been thought through."

What is clear, however, is that, even in its early stages, the POW and MIA issue was thought of as the bedrock of the administration's propaganda initiative. The POW and MIA issue is so foundational to the propaganda campaign, in fact, that it is reasonable to assume that propaganda concerns led President Nixon to agree to meet with

\footnotetext{
White House Central Files, ND 18-3 CO/165; Beginning; 12/31/69; Nixon Presidential Materials; National Archives $_{2}$ at College Park, College Park, MD.$$
{ }_{222} \text { Ibid. }
$$
Special Assistant to President Nixon, Washington, DC, December 6, 1969; White House Central Files, ND 18-3 CO/165; Beginning; 12/31/69; Nixon Presidential Materials; National Archives at College Park, College Park, MD.
} 
POW and MIA family members, despite the initial misgivings about holding such a meeting that were documented above.

Whether the somewhat improvisational issue was effective is difficult to gauge. There is a memo, declassified at my request, written by Colonel Robert E. Pursley, Military Assistant in the Office of the Secretary of Defense, and dated December 29, 1969 that expressed concern about what was gaining the attention of the North Vietnamese delegation. Pursley indicated that he had been "reading closely" the cable traffic between Paris and the State Department on the POW issue. It was his opinion that "compliance with International Conventions and the trustworthiness - or lack thereof - of the NVN vis a vis such international agreements or protocol, seem to have been lost in our recent pronouncements." Furthermore, he indicated that Hanoi's response to other initiatives on POW and MIA matters would possibly benefit American strategy. He wrote: "The precedent of how the Hanoi government acts in conjunction with international agreements and conventions could be a major factor in the way we view any prospective NVN agreements in other areas and /or leverage against Hanoi to make them more forthcoming on the POW issue." ${ }^{223}$

Of course, the monitoring described in the Pursley memo, and the early response of North Vietnam, occurred relatively early in the propaganda offensive. Much happened in the between 1969 and the signing of the Peace Accord in January 1973. During this intervening period, National League members were knocking on the North Vietnamese delegation's door in Paris, Sybil Stockdale met face-to-face with members of the North

${ }^{223}$ Colonel Robert E. Pursley, Military Assistant, Office of the Secretary of Defense, memorandum to Assistant Secretary of Defense (International Security Affairs), Washington, DC, Dec. 29, 1969 , Office of the Secretary of Defense. At my request the memorandum was Declassified on January 20, 2004, Declassified authority EO 12958. 


\section{Chapter Seven}

Vietnamese delegates, wives and family members called on officials in Washington DC, and there were nearly constant letter-writing campaigns to international newspapers. Most of these activities generated extensive international coverage of National League members and their efforts to accentuate the POW and MIA issue. In short, over time, the administration acquired attention-getting allies in its propaganda campaign.

The relationship between the allies (Washington and National League members) remained an arms-length one, however. Administration officials did not prevent members of the National League from going to Paris, but they also did not officially encourage such visits. Some of the memos I read expressed concern about the visits; others readily acknowledged their propaganda potential. But there was always an implicit—and, at times, an explicit — acknowledgement that problems would be minimized and/or the propaganda potential was likely to be maximized if there was no official connection between League members and the government.

The National League also valued its independence. League members understood the importance of being seen as representing themselves and an independent organization rather than official Washington when they knocked on the door of the North Vietnam delegates in Paris.

This arms-length relationship played out in other areas, as well. National League members had come to understand the political milieu in which they were operating and the importance of retaining the option (and the threat) to be critics of, rather than takenfor-granted cheerleaders for the administration. To be sure, the relationship between the League and the government became considerably cozier after the Nixon administration embraced the POW and MIA issue, which Sybil Stockdale told me, was like "an 
The United States Government Responds

afterburner" kicking in. Because of the government's embrace of the issue, the wives and family members gained considerable access to high-level officials along with growing support on Capital Hill. Organizationally, however, the League and its leadership retained their independence. A number of archived memos that I reviewed demonstrated that administration officials, in particular, not only respected Sybil Stockdale; they also, to some extent, feared the influence she could have on the public and League supporters.

The archival material also makes clear that the government and the National League had somewhat different agendas. It probably would not be inappropriate, in fact, to claim that, at times, at least, Nixon administration officials used the women and their cause for the administration's own purposes, i.e., to embarrass the North Vietnamese and, ultimately, to end the war.

Fortunately, for the National League and its members, the two groups' agendas were more complementary than conflicting. No matter what their reasons, officials in the Nixon White House ended up doing what the wives had asked the government to do all along: Put pressure on the North Vietnamese to treat their relatives humanely. In addition, there is some fairly convincing evidence that, after the family members' December 12 meeting with the President, the administration's actions on the POW and MIA issue reflected more than simply using the issue to serve another, grander end. Much of this evidence relates to the stance the government took in negotiations to end to the United States' involvement in the Vietnam conflict.

White House Includes POW and MIA Issue into War Settlement

Three days after the meeting with wives and mothers of POWs and MIAs in the Oval Office, President Nixon addressed the nation; his topic: "Progress Toward Peace in 


\section{Chapter Seven}

Vietnam." In the television address, he spoke about Hanoi's inhumanity regarding POW and MIA matters and their failure to address POW and MIA issues at the Peace negotiations in Paris. He said:

Typical of [North Vietnam] is their absolute refusal to talk about the fate of the American prisoners they hold and their refusal even to supply their names so as to ease the anguish of their loved ones in the United States. This cruel, indefensible action is a shocking demonstration of the inflexible attitude they have taken on all issues at the negotiating table in Paris.

On December 29, 1969, Melvin Laird sent President Nixon a memo, which, in part, discussed Nixon's new interest in making the POW and MIA issue a part of the negotiated war settlement rather than follow the traditional strategy of dealing with the issue after a peace treaty has been successfully negotiated. In this memo, which I managed to have declassified for this study, Laird acknowledged Nixon's intent: "Within the past few days you have reiterated your desire that the highest priority be assigned to the prisoner of war question and that the prisoner problem should be considered separately from other negotiable issues of the war itself."

Laird then recommended a strategy for "specific actions" that would "assist ongoing efforts to obtain the release of and a full accounting for all men who are identified as prisoners or missing in action." Laird codified his proposal to the President in five concise statements, which all sought to ensure the POW and MIA issue remained

\footnotetext{
${ }^{224}$ President, Address to the Nation on progress toward peace in Vietnam, December 15, 1969 , Public Papers of the Presidents of the United States, Richard Nixon, (1969): 486.

Mr. Melvin Laird, Secretary of Defense, memorandum to Richard Nixon President of the United States, Washington, DC, December 20, 1969, Office of the Secretary of Defense. Declassified on January 20, 2004, Declassified authority EO 12958.
} 
inextricably linked with the negotiations to end the war. Laird listed these as follows:

1. Designate a special presidential emissary ... who could visit the capitals of selected countries which previously have expressed a concern for our prisoners of war.

2. An alternative to the above, you could designate a joint White House/National Security Council and Defense Team that could visit the same areas.

3. Our Delegation in Paris should develop a series of hard-hitting statements on the prisoner issue. Such statements made during the negotiations could give emphasis both to the violations of the Geneva Agreement as well as violations to human standards on prisoner treatment.

4. You might wish to reconsider the proposal of designating the Vice President as your personal representative on prisoner matters.

5. We would recommend that when appropriate, your speeches and statements continue to include prisoner of war references. ${ }^{226}$

Part of the effort to incorporate the POW and MIA issue into the Paris Peace negotiations was also referred to in a March 1970 memorandum from Alexander Butterfield to Margarita White, White House Communications. In it, he mentioned, among a number of other issues, the development of a POW task force, which, he said was "in the making." ${ }^{227}$ He also noted plans to not only seek a strategy to force the North ${ }_{227}^{226}$ Ibid.

Alexander P. Butterfield, Assistant Chief of Staff and Special Assistant to President Nixon, to Mrs. Margita White, Assistant to Herbert G. Klein, Washington, DC, March 10, 1970; White House Special Files; Staff Members and Office Files, Alexander B. Butterfield; Correspondence File//January 1969 to June 1970//; Nixon Presidential Materials; National Archives at College Park, College Park, MD. This memo discussed a number of topics, one dealt with whether or not a private visiting should be granted for a POW wife with the President, the other addressed the pressure on the President by the organization "Fighting Home Folks of Fighting Men" for more overt demonstration of his support for POWs and MIAs. 


\section{Chapter Seven}

Vietnamese to comply with the Geneva Convention, it also separated out the POW and

MIA issue and make it a provision within the negotiations to end the war in Vietnam. ${ }^{228}$

Nixon's desire to make the POW and MIA issue a part of the peace settlement continued to be part of his mindset even at the war's end. In 1973, when nearly all as the POWs had been released, President Nixon spoke with Brent Scowcroft, Deputy Assistant to the President for National Security Affairs, and Ron Ziegler in the Oval Office about the Vietnam War settlement issue. Their conversation, which was taped by the secret Oval Office taping system, clearly indicated that, in the President's mind, the settlement to end the war included the release of all prisoners throughout all Indochina. During their conversation, Nixon seeks confirmation from Ziegler about the matter. He said, "You got across the point that we're conditioning that on a withdrawal of the, of the Laotian ones too." Ziegler responded, "The agreement clearly states prisoners throughout Indochina." However, Scowcroft interjected that the agreement did not specifically state Indochina, though he tells the President that his (Nixon's) and Kissinger's separate press conferences established that all prisoners would be released. Ziegler then told the President, "Throughout Indochina. [Unintelligible portion] it's not written." At this point Nixon appeared to lecture both men, especially Ziegler, on the importance he placed on the POWs. It is important to read the comments of the President to understand how Nixon felt about the POW and MIA issue-even to the very end. Nixon said:

228 Alexander P. Butterfield, Assistant Chief of Staff and Special Assistant to President Nixon, to The President's File, Washington, DC, February 1, 1970; President's Office Files; Memoranda for the President; Beginning January 4, 1970-May 31, 1970, February 1, 1970; Nixon Presidential Materials; National Archives at College Park, College Park, MD. Also in Alexander P. Butterfield, Assistant Chief of Staff and Special Assistant to President Nixon, to The President's File, Washington, DC, February 1, 1970; White House Special Files; Staff Members and Office Files; Alexander B. Butterfield, Correspondence, File//January 1969 to June 1970; Nixon Presidential Materials; National Archives at College Park, College Park, MD. 
You see, you see Ron, be sure that you don't let the press go off in some kick that failing withdrawal, we're, they're holding prisoners because the last nine [unintelligible portion] are as important as the first nine. I mean, people understand that, don't you agree? (Ziegler said, "Yes Sir).

Until every last prisoner is out, there will be Americans in and out of Indochina, we're gonna keep Americans, see, we don't, we won't have no military forces whatever in Indochina after we withdraw, you realize that, I have always said that until all of our prisoners are withdrawn, there will be American forces in South Vietnam. And I don't mean just from the North. That's the line. Play it very tough. [Unintelligible portion] see, to see that the Pentagon understands that and the State Department [unintelligible portion]. Okay, fine. ${ }^{229}$

\section{White House Ability to Influence Support}

During my interview with Alexander Butterfield, he drew specific attention to the power of the White House to influence and gain support for their initiatives on any given issue. Assertively, he told me, "The White House has tentacles that you would not believe. Through Governors, State Party Chairman, various labor, civic, and veterans organizations, the White House can reach far and wide in a matter of hours." Moreover, Butterfield discussed that the ability to obtain support for the POW and MIA issue — as well as the National League — was just a phone call away. He said, "When you pick up the phone at the White House it is unbelievable what the response is out there. People jump through the hoops to want to help you."

\footnotetext{
${ }^{229}$ Conversation 887-19; Portion of a conversation between The President and Brent Scowcroft, Ronald Ziegler enters during the conversation [Electronic Records]; Transcript (p. 10-11); The Oval Office; March 22, 1973; Nixon White House Tapes; Records of the National Archives and Records Administration, Cassette Number E501; National Archives at College Park, College Park, MD.
} 


\section{Chapter Seven}

Melvin Laird also alluded to the extent to which the White House's could influence initiatives in a memo he sent to Henry Kissinger. At the President's request, he provided material to Kissinger that the President might incorporate into his 1971 State of the Union address, which specifically included POW and MIA matters. The December 1, 1970, memorandum affirmed that the administration was "attempting new vigorous approaches in behalf of the release of American prisoners of war." Laird included a line about his action to go public but deferred to the administration as being the initiators. He wrote, "In May 1969, the Administration began to undertake new initiatives in order to bring the issue of U.S. prisoners of war before the public eye, both here and aboard." ${ }^{230} \mathrm{~A}$ number of the "new initiatives" came from White House Staff preparing "game plans" on the POW and MIA issue, which included the soliciting or support of activities from individuals or organizations.

President Nixon continued, through various presidential and White House means, to address and keep the POW and MIA issue before the American public. This was evident in the Presidential Proclamation released on March 19, 1971, which designated March 21-27 as, "National Week of Concern for Americans Who Are Prisoners of War or Missing in Action." ${ }^{231}$ The House also passed Joint Resolution 16 of the same title. The signing of the Proclamation and Resolution on March 19, in the Cabinet Room included co-sponsors of the Resolution, Executive Committee of the National League of Families,

230

Mr. Melvin Laird, Secretary of Defense, to Henry Kissinger, Assistant to the President for National Security Affairs, Washington, DC, December 1, 1970; National Security Council Files; Henry A. Kissinger Files, Henry A. Kissinger Administrative and Staff Files; Subject Chronological, August 1969August 1974, Folder 4, 1971 Annual Review; Nixon Presidential Materials; National Archives at College Park, College Park, MD.

Presidential Proclamation, March 19, 1971, enclosed in memorandum from Henry A. Kissinger, Assistant to the President for National Security Affairs, to Richard Nixon, President of the United States, Washington, DC, March 18, 1971; White House Special Files; Ronald Ziegler; Vietnam Prisoner of War, II, 02-19; Nixon Presidential Materials; National Archives at College Park, College Park, 
representatives of Department of State and Department of Defense, and others related to the POW and MIA cause. The President's remarks, which Kissinger advised him on, reiterated the same message about the plight of the men but now included the initiatives of South Vietnam to release North Vietnamese prisoners, which totaled around $250 .^{232}$ The President's Proclamation, however, acknowledged the length of captivity for the longest serving prisoners, now seven years, and indicated that the North Vietnamese had not abided by the Geneva Convention of 1949 for humane treatment of prisoners. The second paragraph echoed the National League's long sought objectives and the administration's desire to embarrass North Vietnam. Nixon's Proclamation reiterated:

This Government has made and will continue to make strenuous efforts in behalf of these Americans who are prisoners of war or missing in action. In the face of the enemy's callous indifference to the plight of these men and their families, we have sought to focus the attention of the world on the barbaric attitude of North Vietnam and its agents throughout Indochina. We have conducted vigorous diplomatic efforts to resolve the prisoner of war problem on a purely humane basis for the prisoners we hold as well as for our brave men held prisoner. ${ }^{233}$ The President concluded his Proclamation with a request to the American people to observe the week in prayer "and in ceremonies and activities appropriate to voice deep

\section{MD.}

232

Henry A. Kissinger, Assistant to the President for National Security Affairs, to Richard Nixon, President of the United States, Washington, DC, March 18, 1971; White House Special Files; Ronald Ziegler; Vietnam Prisoner of War, II, 02-19; Nixon Presidential Materials; National Archives at College Park, College Park, MD.

Presidential Proclamation, March 19, 1971, enclosed in memorandum from Henry A. Kissinger, Assistant to the President for National Security Affairs, to Richard Nixon, President of the United States, Washington, DC, March 18, 1971; White House Special Files; Ronald Ziegler; Vietnam Prisoner of War, II, 02-19; Nixon Presidential Materials; National Archives at College Park, College Park, MD. 


\section{Chapter Seven}

concern for the prisoners and missing men, to inspire their loved ones with new courage and hope, and to hasten the day when their ordeal may end..$^{234}$

Attention Must be Paid! The Wives Interactions with the President and Other White

House Officials in the Early 1970 s

The Multiple Meanings of Meetings with White House Officials

During the years that followed the President's December 1969 meeting with the select group of wives and family members, the arduous experience of being a POW or MIA wife or family member began taking a definite mental, emotional, and physical toll on many wives and other family members. Some began to limit their involvement in National League activities; others withdrew completely due to absolute exhaustion. Even among those who remained in the organization through the subsequent years, there was growing discontent and increasing frustration with the lack of resolution of the POW and MIA issue and the war itself. White House documents indicate that the White House was quite aware of - and increasingly concerned about — this state of affairs.

Because of this concern, high-ranking White House officials continued to meet with groups of wives. Many of these meetings involved Henry Kissinger, the President's National Security Advisor and, in time, his Secretary of State. Documents indicate that these meetings occurred both in the White House and at the so-called Western White House in San Clemente, California.

The wives I interviewed had favorable recollections about Kissinger's involvement with them. Marty Halyburton and Phyllis Galanti, for instance, told me of a meeting with Dr. Kissinger that in which they participated. During this meeting, the

${ }^{234}$ Ibid. 
wives were adamant that they needed to be given more information on the status of their husbands. Marty remembered Kissinger "beating his fists down on the table... . He raised his voice and said, 'I give you my word - there's more happening than I can tell you-your men are our first priority."' Phyllis indicated that she understood that Kissinger could not tell the wives the "more [that was] happening," but she was confident "he understood our frustration. .. . even if we didn't get a whole lot of information." Phyllis also alluded to the wives having a sense of validation because of the interest by Kissinger and the White House. "Our talking and his listening. ... [were] valuable from that perspective, even if we didn't get a whole lot of information," Phyllis said.

Other wives also were positive about Kissinger and their meetings with him. For instance, Alice Stratton, who met with Kissinger on a number of occasions, characterized Kissinger, during these meetings, as being "responsive . . very honest . . . and open." Sybil Stockdale also had a positive view of Kissinger and his interactions with family members. In a speech she wrote in the late 1970s for presentations to varied audiences, Sybil indicated that "Henry Kissinger has never received the public acknowledgement he deserves for those patient hours he spent with us explaining over and over how the North Vietnamese negotiate and always giving us his honest appraisal of the chances for peace in the next six months or a year. We weren't an easy or happy group to deal with in those days and to his great credit, he never ducked us or gave us less than his honest opinion." ${ }^{235}$

Sandy Dennison told a more personal story about meeting with Kissinger, a story that seems to suggest that Kissinger was a bit different from his image as a heady and

\footnotetext{
${ }^{235}$ Sybil Stockdale, unpublished data, private collection.
} 


\section{Chapter Seven}

unemotional intellectual and policy strategist. Sandy told me that she had contacted Commander Boroughs and asked him to set up an appointment so she could speak with Kissinger. She wanted to question Dr. Kissinger about the fact that she had received information about her husband's situation from a peace activist who had gone to North Vietnam with Jane Fonda and members of the Chicago Seven. ${ }^{236}$ Even decades later, her voice suggested her frustration with the fact that the American government could not obtain solid information on her husband, yet anti-war activist - with relative easetraveled to Hanoi, returned with information on POWs, and even carried letters for POW families. Her frustration was fueled, in part, by the fact that the anti-war activist who had met with her to share information about her husband also had told her that her husband "got what he deserved."

Eventually, Sandy had her private meeting with Kissinger. She told me that, unlike the antiwar activist, "he [Kissinger] was very kind" and sympathetic to her predicament. He assured her that, in the future, he would give her as much information as he could but told her that America's information "sources are very limited and we don't want to hamper any of the sources." At that point, Sandy asked Kissinger if she was to believe the validity of the POW and MIA list anti-war activist had produced, which indicated her husband had died in prison. She said that Kissinger took her by the hand and said, with considerable compassion, "Sandy, I think you should start a new life."

Thus, the stories that the wives told suggest favorable treatment by White House officials during the early 1970 s. White House documents, however, suggest that the story

${ }^{236}$ The Chicago Seven were a group of individuals charged with conspiracy, inciting to riot, along with other charges related to violent protesting that took place at the 1968 Democratic National Convention in Chicago, Illinois. 
The United States Government Responds

may be a little more layered and the motives of Kissinger and others may have been more complex than simply wanting to express humanitarian concern and provide comfort.

One memorandum, dated May 3, 1971, from Dave Packard, Under Secretary of Defense, to Dr. Kissinger, suggest concern within the White House over the "understandable impatience and exasperation" of families was, indeed, genuine.

However, the memo also reveals a more Machiavellian agenda. Packard wrote:

They [the families] could easily, as they are urged by many, join with dissenting groups to make a satisfactory resolution of the conflict more difficult. It is important that these families continue to support US efforts.

I believe it is advisable that you meet with them [National League Board of Directors] and discuss the hazards to their cause of becoming involved in the political aspects of the problem, and attempt further to define US policy regarding our missing and captured men in terms that assure the families that all feasible efforts are being made. ${ }^{237}$

Other White House documents articulated concerns. In a memorandum to President Nixon, dated April 15, 1971, Brigadier General Hughes (formerly Colonel) referred to an early April meeting that Nixon had had with Senator Robert Dole regarding POW and MIA families. Hughes told the President that the meeting had been brought to his attention because it had left him (Nixon) "with great concern that the families of the POW and MIA are about to defect spontaneously and in large numbers from a position of

\footnotetext{
${ }^{237}$ David Packard, Deputy Secretary of Defense, to Henry A. Kissinger, Assistant to the President for National Security Affairs, Washington, DC, May 3, 1971; White House Central Files, ND 18-3; Prisoners; 1/1/71-[1972]; Nixon Presidential Materials; National Archives at College Park, College Park, MD.
} 


\section{Chapter Seven}

at least tacit support of the administration to the peace groups and others who oppose our efforts in Southeast Asia."

Because of the President's level of concern, Hughes assured the President that he would work with the National Coordinator of the National League to determine the seriousness of the potential defection. He informed the President that his "preliminary survey. . . . indicates that there is no immediate move towards a mass defection." He did, however, let the President know there was "considerable frustration, disappointment and in some cases, despair." Hughes memo also discussed "morale remedies" that were designed to "prove to families how deeply he [Nixon] and the Administration [were]...interested in the welfare of their men and, of course, the families." To provided further support to the families and demonstrate administration commitment to the matter, the Advertising Council agreed to conduct a nation-wide campaign on behalf of POWs and MIAs. General Hughes, quite candidly, told the President that the initiatives are "of a cosmetic nature- - but designed to provide an immediate uplift in the moral of the families." ${ }^{239}$

Thus, the motives that prompted White House officials to meet with members of the National League are nothing if not complex. The wives remember meeting with human beings who were genuinely concerned about their welfare and the welfare of their husbands. There is no reason to believe this interpretation is totally erroneous. After all, after years of witnessing so-called Washington Road Shows, the wives had developed considerable skill in sniffing out disingenuous behavior.

238

Brigadier General James D. Hughes, Military Assistant to the President, to Richard Nixon, President of the United States, Washington, DC, April 15, 1971; White House Central Files, ND 18-3; Prisoners; 1/1/71-[1972]; Nixon Presidential Materials; National Archives at College Park, College Park, MD. 
The United States Government Responds

But the human beings that worked in the White House were also, first and foremost, politicians. Consequently, it is reasonable to conclude that the attention they paid to the wives and their cause had a great deal to do with the fact that White House officials greatly valued the tacit support (or, at least, the official neutrality) of a group of women who had attracted national attention for their cause. White House documents tend to confirm this interpretation.

\section{Nixon and Laird Speak at a National League Convention}

One indicator of increasing political clout of those associated with the National League in the early 1970 s was the fact that both President Nixon and Secretary of Defense Melvin Laird spoke at National League's Annual Convention on September 28, 1971. The mere fact that both of these government officials appeared at the convention speaks to the League's perceived importance within the administration. But the content of both speeches also speak to the success of League members in overturning the earlier policy of Quiet Diplomacy and making the POW and MIA issue an explicit part of the national conversation. The speeches were the antithesis of the canned speeches politicians normally deliver on the "rubber chicken" circuit. Both speakers took note of the magnitude of the wives arduous journey and also assured audience members that the government was, indeed, continuing to address the POW and MIA issue at the highest levels. President Nixon, in fact, assured the group that the POW and MIA issue was his "presidential priority." He said:

As you can imagine, whoever holds the office of the Presidency cannot take upon himself all of the various assignments that come across his desk. Much must be

${ }^{239}$ Ibid. 


\section{Chapter Seven}

delegated. I want each and every one of you to know, however, that from the time in the White House Library, at Christmas time, 1969, I met a group of wives and one mother of some POW's and missing action, from that time ... I have considered the problem of obtaining the release of our POW's and missing in action as being one that has presidential priority. ${ }^{240}$

At the outset of his speech, Melvin Laird acknowledged how widespread the wives influence has been. He said, "You have won the admiration of the nation and of a great part of the civilized world because you have borne uncertainty and loneliness with dignity and courage." ${ }^{241}$

In his speech, Melvin Laird also repeated a refrain well known to the POW and MIA wives and family members. It was a line they publicized in their letters, their speeches, and used in their conversations. It was simply: "The Geneva Convention requires ..." Laird repeated this phrase along with specific Geneva Convention requirements nine times in his speech. Each time, of course, he took note of North Vietnam's failure to comply with international law over the long course of the war.

Laird's acknowledged his own participation in the struggle as well as the significant contributions made by the wives and family members. He said, "If together we continue to persevere, to remain united in purpose, to continue to keep the question of the prisoners and the missing high on the list of international priorities, we will achieve the

${ }^{240}$ Richard Nixon, President of the United States, to the Annual Meeting of the National League of Families of American Prisoners and Missing in Southeast Asia, Washington, DC, September 28, 1971; White House Special Files; Ronald Ziegler; Vietnam Prisoners of War, I, 02-19, [2 of 2]; Nixon Presidential Materials; National Archives at College Park, College Park, MD.

Melvin R. Laird, Secretary of Defense, to the Annual Meeting of the National League of Families of American Prisoners and Missing in Southeast Asia, Washington, DC, September. 28, 1971; White House Special Files; Ronald Ziegler; Vietnam Prisoners of War, I, 02-19, [2 of 2]; Nixon Presidential Materials; National Archives at College Park, College Park, MD. 
The United States Government Responds

objective for which we have been working." ${ }^{242}$ (For transcripts of the speeches, see Appendices $\mathrm{H}$ and I.)

The National League Demands/the Administration Responds: The Formation of the NonPartisan Political Action Committee

If the decision to have both the President and his Secretary of Defense speak to the 1971 National League convention was made, in part, for political reasons and to placate an increasingly powerful interest group, the appearances did not completely accomplish this goal. After the two spoke, in fact, the National League's membership voted to send a series of questions they wanted President Nixon to address.

The copy of the letter from the League to the White House that I reviewed had no date on it, but the White House response, prepared by Dr. Kissinger and sent to Carol Hanson, Chairman of the National League of Families, dated December 22, 1971. The response's bottom-line message was clear and simple: providing answers to the questions that had been posed would not serve either "national interests or interests of the men."

By early 1972, as was alluded to in an earlier chapter, the POW and MIA wives and families had become even more dissatisfied with the seemingly endless war and the continuing uncertainty about a resolution on the POW and MIA issue. In part to respond to the rising level of dissatisfaction, but also because of the presidential election scheduled for November of 1972, the League formed the Non-Partisan Political Action Committee. The Committee's somewhat cumbersome name is reflective of an attempt to respond to the growing dissatisfaction with the Nixon administration's handling of the

$$
{ }^{242} \text { Ibid. }
$$
Hanson, Chairman Board of the National League of Families, Washington, DC, December 22, 1971; White House Special Files; Ronald Ziegler; Vietnam Prisoner of War, I, 02-19; Nixon Presidential Materials, 


\section{Chapter Seven}

war in Vietnam while not totally abandoning the group's commitment to nonpartisanship, a commitment that had served the group well during its earlier years.

Phyllis Galanti, who was on the National League's Board of Directors, wrote a letter to League members about Board's January 22-23, 1972, meeting that discussed the formation of the Non-Partisan Political Action Committee. She wrote that the members on this committee "will ensure that the candidates throughout the country are asked key questions on the prisoner-missing issue either by newsmen or by family members themselves." And, as previously mention, she told members: "No part of this Committee's activities will involve the endorsement or opposition of any candidates." ${ }^{244}$ A sense of how the Committee's balancing act would actually play out can be found in a February 28, 1972, letter that Mrs. Joan Vinson, National League Board of Directors Chairman, sent to President Nixon. In her letter, Mrs. Vinson informed Nixon of the establishment of a "Non-Partisan Political Action Committee" within the National League of Families. The committee, she told the President, was comprised of families and friends of POWs and MIAs who were charged with keeping the POW and MIA issue before the public during the 1972 presidential election. The letter informed the President that the National League would expect all presidential candidates "to state what they would do, if elected, to settle the war and achieve the release of prisoners and an accounting of the missing." Specific questions related to this expectation also were included in the letter.

\footnotetext{
National Archives at College Park, College Park, MD.

In the letter, Phyllis Galanti also informed them of several other committees the Board "set up which will deal at the national level with specific areas of effort." The committees included (a) MIA/POW Readjustment and Rehabilitation, (b) Finances, Public Action and Publicity, (c) Legislative, National Organization, and (d) Foreign Nations. Phyllis Galanti, unpublished data, private collection.
} 
Mrs. Vinson also explicitly stated, in her letter, that the women did not want to hear arguing and bickering among the candidates about the POW and MIA issue. Rather, their goal was "to elicit a plan for the future." She concluded her letter by reminding the President, one more time, that the Non-Partisan Political Action Committee's request was for specific information about future actions and that his response to their request was "part of the democratic decision-making process."

The White House did not respond to Mrs. Vinson's request, but White House documents indicate that the memo - and the League's Non-Partisan Political Action Committee, in general — did not go unnoticed. Indeed, it would have been difficult for the White House to ignore the actions of the League's Non-Partisan Political Action Committee because members of the committee were both persistent and omni-present during the course of the election year.

For instance, when there was no official reply to her first letter to the White House, Mrs. Vinson wrote again. In a letter dated March 17, she informed the President there had been no response to their previous letter. She also noted that the National League's Non-Partisan Political Action Committee would conduct a press conference on March 21 to discuss the candidate's answers to their questions. ${ }^{246}$ The press conference was held, however, on March $27 .^{247}$

Mrs. Joan M. Vinson, Chairman, Non-Partisan Political Action Committee, National League of Families, to Richard Nixon, President of the United States, Washington, DC, February 28, 1972; White House Special Files; Ronald Ziegler; Vietnam Prisoner of War, I, 02-19; Nixon Presidential Materials, National Archives at College Park, College Park, MD.

Mrs. Joan M. Vinson, Chairman, Non-Partisan Political Action Committee, National League of Families, to Richard Nixon, President of the United States, Washington, DC, March 17, 1972; White House Special Files; Ronald Ziegler; Vietnam Prisoner of War, I, 02-19; Nixon Presidential Materials, National Archives at College Park, College Park, MD.

To date, I have not been able to locate a transcript of the meeting. 


\section{Chapter Seven}

The White House did respond to Mrs. Vinson. In a letter dated March 27, 1972,

General Scowcroft, provided Mrs. Vinson with two enclosures with answers to the committee's questions. Scowcroft told her: "There are no easy answers to the questions you have asked, but as you requested I am forwarding statements which set forth the Administration's views and efforts on these issues." ${ }^{248}$

In May of 1972, additional pressure was applied. Chairman of the National League's non-partisan political action committee, Joan Vinson, sent another letter to the President, in which the Committee requested — or, to be more precise, demanded - a meeting with him. ${ }^{249}$ The letter indicated that the purpose of the meeting was to discuss the President's plans in Southeast Asia, the negotiations in Pairs at the Peace Talks to release the prisoners, and what measures were being taken to account for the missing. The letter was signed by so many wives that the signatures cover two pages.

As has already been suggested, the letter's tone was quite demanding. The committee, the letter stated, considered it "imperative that we be given the opportunity to discuss with you. ... imperative that you understand the feelings of the families. . . we feel justified in making this demand upon your time and invoking the presidential priority." 250

Accompanying the letter was a resolution from the National League of Families that stated the families' demands on the administration. The resolution stated that it was

248

General Brent Scowcroft, Military Assistant to the President, to Mrs. Joan Vinson, Chairman, Non-Partisan Political Action Committee, National League of Families, Washington, DC, March 27, 1972; White House Special Files; Ronald Ziegler; Vietnam Prisoner of War, I, 02-19; Nixon Presidential Materials, National Archives at College Park, College Park, MD.

Mrs. Joan M. Vinson, Chairman, Non-Partisan Political Action Committee, National League of Families, to Richard Nixon, President of the United States, Washington, DC, May 7, 1972; White House Special Files; Ronald Ziegler; Vietnam Prisoner of War, I, 02-19; Nixon Presidential Materials, National Archives at College Park, College Park, MD.

Ibid. 
The United States Government Responds the League's purpose to "make known and reaffirm its extreme distress at the failure of this administration's policy to resolve the POW-MIA issue . . . and expect the government to immediately adopt a policy which will ensure an accounting of the missing men and the release of the prisoners of war. ${ }^{251}$ In a bold statement, the National League informed the administration it would elect three members at the May 5-7 annual National League convention, who in turn, would - within ten days - meet with the President and immediate report back to the National League membership. ${ }^{252}$

Phyllis Galanti told me of other actions by the Non-Partisan Political Action Committee. She noted, for example, that some members of the League who attended the May, 1972, convention protested, in front of the White House, what they believed was the government's mediocre response to the POW and MIA issue. She read to me the following statement she had written in May 1972 for the National League of Families newsletter:

During our day in Washington, some of the wives wanted to display their feelings by forcefully picketing in front of the White House. While I am not ready to do that; yet [sic] I am much more tolerant of others' views than I was before the meeting. Each of us has her own cross to bear and each circumstance is different. Although the President's appearance before our group was encouraging, that 10 minute appearance will not carry me through another year. This is not just another cause for us. Our very lives are at stake. Personally, I am going to

$$
\begin{aligned}
& 251 \text { Ibid. } \\
& \text { Ibid. }
\end{aligned}
$$




\section{Chapter Seven}

continue to do everything possible to get our men home and I trust that the

President and the Congress will do likewise. Our men deserve no less. ${ }^{253}$

Phyllis also noted that she and other members of the Non-Partisan Political Action Committee "roamed around and buttonholed people" at both the Republican and the Democrat national conventions as part of their non-partisan yet highly political activities during the presidential year. Like other conventioneers, they wore hats, but instead of candidate's name, they had a bumper sticker that said, "POWs-MIAs dying to vote in '72." At the Republican Convention, Phyllis told me that when President Nixon appeared on the platform the audience began chanting, "Four more years! Four more years!" Phyllis said the person next to her was joining in the chorus. Phyllis, however, shouted: "Heck no! Not four more years of what we've had. My husband's been a POW for six years and I don't want four more years of the same stuff."

When I asked Phyllis if she thought the political action committee strained relationships within the National League or between the National League and the administration, Phyllis reminded me by back to the requirement that the committee was to preserve itself as a nonpartisan group. She told me, "Even though some of us had personal feelings, they were never part of the effort. Any disagreement certainly wasn't voiced publicly. We were trying to bring pressure on all the candidates." Later in the interview, she framed the National League's desire to contain direct public criticism of the administration, even while the League was putting considerable pressure on the administration privately. She said, "We all realized there was too much at stake for any of that to become public."

${ }^{253}$ Phyllis Galanti, unpublished data, private collection. 
None of this went unnoticed by members of the administration. Government documents indicate that administration officials continued to appreciate the Leagues nonpartisan stance, were aware of pressures within the organization to abandon its nonpartisan strategy, and were fearful of the consequences for the administration and its policies should this happen, especially in an election year. General Al Haig, for example, in an undated memorandum, provided a nine-page response for General Scowcroft, Military Assistant to the President to the questions the League had asked the President to answer. $^{254}$ General Haig indicated that, at one level, he did not believe that providing specific answers to the League's questions was a good idea. He noted that "the issues are complex and other senior Administration officials ... have addressed them in considerable detail." However, he acknowledged that he and others in the administration who had maintained contact with the National League had a strong sense that the "League's candidate project and their current mood makes it absolutely essential to provide specific answers."

Interestingly, the President of the United States also acquiesced to the demand that he meet with League representatives. The details of the meeting will be discussed in the next section. Here, it is sufficient to note that the files suggest that, this time, the White House staff did not play Hamlet with the question of whether or not to hold the meeting. Undoubtedly, election year politics made the decision relatively easy to make. And, almost certainly, the somewhat radical element that had emerged within the League influenced the decision to acquiesce to the League's demand for another meeting with the

${ }^{254}$ General Al Haig Jr., Senior Military Assistant to the President, to General Brent Scowcroft, Military Assistant to the President, Washington, DC; undated; White House Special Files; Ronald Ziegler; Vietnam Prisoner of War, I, 02-19; Nixon Presidential Materials, National Archives at College Park, College Park, MD. 


\section{Chapter Seven}

President. Even Sybil Stockdale, who had always argued that the National League refrain from engaging in partisan politics, seems to appreciate the positive role that the more radical element within the League played prior to the election.

Of course, there is another part to the story. It is unlikely that the League's demands would have been accommodated had the organization not remained officially neutral and non-partisan. As long as criticism of the administration came from individuals within the League rather than from the official organization, itself, there was an incentive for administration officials to attend to the League's concerns, if only to keep the organization from aligning with the administration's critics on the Vietnam War. The notion of a non-partisan political action committee may be a bit of an oxymoron, but the League's decision to form such an odd-sounding committee and the administration's response to it suggest that, in politics, oxymorons can be exceedingly functional.

\section{President Nixon Meets with National League Leadership}

On May 15, 1972, Sybil Stockdale, Maureen Dunn, and Phyllis Galanti met with President Nixon and Henry Kissinger at the White House. I was not able to find any archival material related to the meeting (other than Kissinger's May 13, memo to the President, which included "Talking Points"), though the White House taping system might have recorded it. ${ }^{256}$

What is currently available is a transcript of the press conference that the women held in the Rose Garden after the meeting. Sybil told me that the White House had made

${ }_{256}^{255}$ Ibid.

Sybil revealed she had interjected some humor into the meeting with a recommendation that the Marines go ashore in North Vietnam and "claim it as U.S. territory. . . . until all Americans are released and accounted for." Reporters asked what the President said and Sybil told them, "He laughed. . . He smiled handsomely." 
The United States Government Responds

meeting with the press optional; but she said she had learned, by this point, that unless the press documented an event, the event, for all intents and purposes, never happened.

The White House transcript of the press conference revealed the women were knowledgeable and in command of the POW and MIA issues. They articulated the complexities of the government's policies well and exhibited confidence. The transcript also suggested that the White House decision to acquiesce to the League's demand for a meeting had an exceedingly positive payoff in an election year.

Maureen Dunn, for example, told the reporters that she felt that the President "answered even the questions for the dissident factors [i.e. factions] in our League." Maureen, the only MIA wife present at the meeting, also expressed confidence about the President's commitment to accounting for the missing, not only in South Vietnam, but also in Laos and Cambodia. ${ }^{257}$

Phyllis Galanti told the reporters that she had been "very, very critical of the Administration in recent months; she added, "I wanted with all my heart to be convinced that everything possible was being done. . . the meeting today has given me assurance." One reporter asked if the President had given them any "optimism." Phyllis responded and told the reporters that as they left the Oval Office the President had said, "Our long vigil would end." She added, "He felt confident that that day [the return of the POW and an accounting of the MIAs] was coming." ${ }^{258}$

Just before their meeting with the President and White House staff members, President Nixon had made the decision to mine Haiphong Harbor. In her press conference

${ }^{257}$ Office of the White House Press Secretary, to Press Release, Washington, DC, May 15, 1972; White House Special Files; Ronald Ziegler; Vietnam Prisoner of War, I, 02-19 [2 of 2]; Nixon Presidential Materials 258 ational Archives at College Park, College Park, MD.

Ibid. 


\section{Chapter Seven}

comments, Sybil Stockdale referred to this decision and told the reporters that Nixon

gave his assurances "that the harbor would stay mined until the prisoners are released."

Thus, the women said positive things about the President and his administration during the press conference that followed their meeting with the President and highranking White House staff. They also were quite critical of one of the White House's major critics on the Nixon administration's handling of the Vietnam War, Senator William Fulbright (D-AR), chairman of the Senate Foreign Relations Committee. ${ }^{260}$

The women, however, stuck to their well-established game plan and did not to take sides on the war, itself. Sybil Stockdale, in fact, explicitly stated the following during the press conference: "Our organization, as you know, takes no position on any political issues at all." Thus, the leadership within the League still understood that taking a stand on the war would limit support for them and their cause and distract from their central concern, bringing their husbands home. In addition, at this point, publicly supporting - or opposing - the administration's continuation of the war would, almost certainly, has created internal problems within the League itself. Sybil also mentioned this point during the press conference. "We have, within our organization, probably every political point of view that you could imagine in this country." At another point during the press conference, Maureen Dunn articulated this same idea, albeit in a somewhat more colorful way. She stated that the League was made up of "doves and hawks" as well as "pigeons and whatever."

$$
\begin{aligned}
& { }_{259}^{259} \text { Ibid. } \\
& { }_{261} \text { Ibid. } \\
& \text { Ibid. }
\end{aligned}
$$


Thus, instead of criticizing Senator Fulbright's position on the war itself, the wives expressed a more focused criticism about the Foreign Relations Committee's failure to hold a single hearing on the prisoner issue since the first prisoner was taken captive in 1964. During her press conference remarks, in fact, Sybil took note of "a strongly worded resolution condemning the Senate Foreign Relations Committee" that had recently been adopted by the league, and then she stated: "We [the National League of Families] consider the committee derelict in its responsibilities, and we said so." Nixon's Support of the POW and MIA Issue in the Early 1970 s

The White House files I reviewed indicate that once the POW and MIA issue got on the White House radar screen, the issue continued to be a significant concern to the President and members of his staff. In a memorandum dated April 19, 1971, for example, Kissinger recommended the President address, in his April 20 meeting with International Red Cross (IRC) President Marcel Naville, the POW issue by focusing on Hanoi's refusal to afford our men the protection of the Geneva Convention. ${ }^{263}$ He admonished the President to impress on Naville the importance of the POW issue while expressing hope that prison camps in North Vietnam would be inspected by the IRC. The President was encouraged to urge the IRC would do all it could on behalf of the prisoners and to "press Communist authorities in Laos and South Vietnam for information on our POW's there." ${ }^{264}$

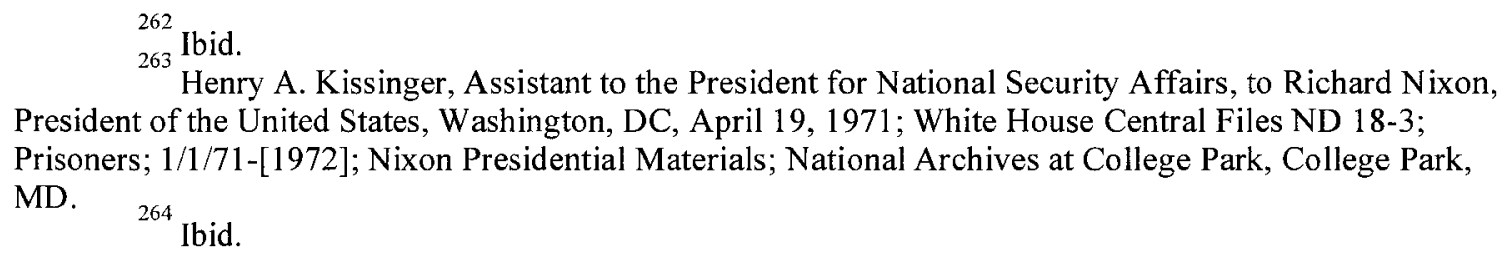
President of the United States, Washington, DC, April 19, 1971; White House Central Files ND 18-3; Prisoners; 1/1/71-[1972]; Nixon Presidential Materials; National Archives at College Park, College Park, ${ }^{264}$ Ibid. MD. 


\section{Chapter Seven}

I also found a comprehensive document sent by Al Haig to John Erlichman on December 16, 1971; the document was titled, "Preparation of National Security Issues Papers." The section that focused on the administrations' policies to end the war and "win" the peace highlighted the initiatives taken by the President on POW and MIA matters. The unnamed author(s) of the report wrote, "Unlike the previous administration, President Nixon brought the plight of our prisoners of war to the attention of the world. He has tirelessly and unceasingly pursued every possible avenue to secure their release or at least the humane treatment to which they are entitled by the Geneva Convention." ${ }^{265}$

\section{On February 9, 1972, President Nixon sent "A Report to Congress" on POW} matters, February 9, 1972. The document stated, "No single issue has received greater attention or been the subject of more intense efforts ... than the plight of our prisoners of war in Indochina." In the report, the President summarizes his initiatives since July 1970 and his administration's ongoing efforts to secure POWs "proper treatment and prompt release." 266

In addition, on March 10, 1972, President Nixon signed his second Presidential Proclamation on the POW and MIA issue at the request of S. J. Resolution 189, "National Week of Concern for Americans Who Are Prisoners of War or Missing in Action" (Appendix J). The tone of this Proclamation was a bit different from the tone of earlier documents on the POW and MIA issue. The report's language was forthright, and the

${ }^{265}$ Al Haig, Jr., Senior Military Assistant to the President, to John Ehrlichman, Counsel to the President and Assistant to the President for Domestic Affairs, Washington, DC, December 16, 1971; National Security Council Files; Henry A. Kissinger Office Files, HAK Administrative and Staff Files; Subject Chron, August 1969-August 1974; Nixon Presidential Materials, National Archives at College Park, College Park, MD.

Richard Nixon, President of the United States, to Congress, Washington, DC, February. 9, 1972; White House Special Files; Ronald Ziegler; Vietnam Prisoner of War, I, 02-19; Nixon Presidential Materials, National Archives at College Park, College Park, MD. 
report expressed harsh criticisms of the North Vietnamese. The report noted, for instance, that several men were beginning their ninth year in captivity and that 1,623 American servicemen were listed as POW or MIA. Nixon's Proclamation stated, "The POW and MIA story of this long and difficult war is a tragic one... . This is the longest internment ever endured by American fighting men; it is also one of the most brutal." ${ }^{267}$

Arguably the most convincing evidence that the POW and MIA issue remained on the President's mind and on the Administration's policy agenda comes from a source that was not intended to be a public document, i.e., a tape from the secret taping system that Nixon had installed in the Oval Office. ${ }^{268}$ Of the 312 tapes that the National Archives index refers to the POW and MIA issue, only three had been transcribed at the time of this study. One of these transcripts was from April 11, 1973. The transcript includes a record of a conversation between President Nixon and Roger Shields, Head of the Department of Defense POW and MIA Task Force. The twenty-three minute conversation took place a month after the last POW was released. ${ }^{269}$ During the conversation, President Nixon asked Shields if he was working on the MIA issue. When Shields told him he was, Nixon replied by saying that he "consider[ed] it [accounting for MIAs] of highest importance ... that ... we go to every effort possible, [every effort] is made on the MIA. . . . leaving no stone unturned." The President added: "I can think of those families that have waited so long, always hoping, and, of course, always

${ }^{267}$ Richard Nixon, President of the United States, to Proclamation 4115, Washington, DC, March 10, 1972; White House Special Files; Ronald Ziegler; Vietnam Prisoner of War, I, 02-19; Nixon Presidential Materials, National Archives at College Park, College Park, MD.

As noted earlier, NARA White House tape logs indicate 312 Oval Office conversations related to POW and MIA matters.

Conversation 893-13; Portion of a conversation between The President and Roger Shields [Electronic Records]; Transcript (p. 18); The Oval Office; April 11, 1973; Nixon White House Tapes; Records of the National Archives and Records Administration, Cassette Number E501; National Archives at College Park, College Park, MD. 


\section{Chapter Seven}

wondering, you know, when they get this first list, well, maybe, maybe somebody's

alive." Later in the conversation he told Shields he wanted him to write the MIA families, as the President, himself, had done earlier, and tell the families that the "President ... does not consider the peace ... won until we get an absolute, complete, satisfactory account of all MIAs." Nixon said he considered this his "highest priority."

During their conversation, Nixon and Shields also discussed the December 1972 bombing campaign by American bombers that targeted positions in and around Hanoi. During this portion of the conversation, Nixon brought up the POW issue. He told Shields that, in late 1972, "the North Vietnamese had reneged on the [Paris Peace] agreement" by attaching conditions to the return of POWs. Nixon told Shields how the United States had responded to the North Vietnamese: "We said no conditions." Nixon then added: "That's why we had to bomb. One of the major reasons we had to bomb. And it worked. ${ }^{1271}$

Thus, the evidence suggests that, after the 1969 meeting between the President and the POW and MIA family members, the POW and MIA issue continued to influence United States policy. The impact may have had something to do with the compelling story that the women told the President and the Presidents seemingly empathic response to it. However, as Alexander Butterfield told me, the President was first and foremost a

\footnotetext{
${ }_{271}^{270}$ Ibid.

During one of my interviews with Sybil Stockdale, she told me that after her husband returned from prison he had a one-hour private meeting with President Nixon. After the meeting, Sybil's husband told her that the President had asked him a question that he did not understand, which, he said, had to do with a renewed bombing campaign in North V ietnam. Sybil told me that she told her husband, "Kissinger said [that] was the plan all along. They knew the North Vietnamese were not going to abide by the terms of the treaty, so they signed it to get the prisoners out. Then after they got the prisoners out, they were going to go back in and bomb the North Vietnamese into abiding by the treaty." But, they couldn't do it, she told me, because the next week John Dean went to the Prosecutor about Watergate.
} 
political animal, and White House documents provide ample evidence of political pressure being applied from a wide range of sources on the POW and MIA issue.

\section{Pressure to Keep the POW and MIA Issue on the Agenda}

There is considerable documentation, in fact, that White House staff kept the President current on POW and MIA initiatives by American citizens and companies. These updates included information about Perot's "United We Stand," and activities conducted by civic clubs and groups, committees, and professional organizations.

The President, for instance, was briefed on a whole range of initiativeseverything from the National Football League's and National Basketball Association Commissioner's "10 Tons of Mail" campaign which enlisted sports fans to write letters supporting the prisoners ${ }^{272}$ to the Longshoreman's Association's willingness to end its eighteen-year boycott of Soviet cargo and passenger ships if Moscow was able to convince Hanoi to release five American POWs in return for each vessel serviced in United States Atlantic or Gulf Coast port. ${ }^{273}$

The files also contained copies of letters from the President to groups focused on the POW and MIA issue. In a letter to the Scabbard and Blade Society of Murray State University, for example, President Nixon expressed his appreciation to the "publicspirited members" of the Society because of their "Pen Power" initiative for POWs. He stated that such concern "offers fresh hope for those brave Americans whose well-being

272 Jeb S. Magruder, Special Assistant to the President, to Dwight Chapin, Washington, DC, Dec. 8, 1970; White House Central Files, ND 18-3; Prisoner; [1969-1970]; Nixon Presidential Materials, National Archives at College Park, College Park, MD.

Alexander P. Butterfield, Assistant Chief of Staff and Special Assistant to President Nixon, to Richard Nixon, President of the United States, Washington, DC, Dec. 15, 1969; President's Office Files; President's Handwriting; December 1969_January 15, 1969, December 1-15, 1969; Nixon Presidential Materials; National Archives at College Park, College Park, MD. 


\section{Chapter Seven}

is of primary importance to all of us." It was his opinion, he said, that such groups were a support to the government's "unceasing efforts" on the POW issue. ${ }^{274}$

The files I reviewed also documented lobbying efforts within the White House staffers to keep the POW and MIA issue on the Administration's policy agenda. In one memo I read from White House staff member, George Bell, to Jim Keogh, Chief of the White House research and writing staff, for instance, Bell argued for the inclusion of a "complete sentence or so on the POWs" in the Veterans Day Proclamation by the President. Bell even acknowledge in his memo that he had "held up release" of the Proclamation in order to obtain the additional statement. ${ }^{275}$

As was the case with other actions that occurred in the White House, however, it is clear that Bell's was motivated more by political than humanitarian concerns, for after Bell requested that a sentence about the POWs be included in the Proclamation, he provided a rationale for doing this. His rationale emphasized that such a statement would "satisfy our pressures."

Data from Harris Poll conducted in 1972 provides quantitative evidence of the "pressures" to which Bell's memo alludes. Throughout 1971 and the first half of 1972 , poll figures indicated that three-quarters of the American public wanted American troops withdrawn from Vietnam. On June 12, 1972, the Harris polling company asked a somewhat different question: "Suppose you had to choose between the U.S. ending all

${ }^{274}$ Richard Nixon, President of the United States, to Scabbard and Blade Society, Washington, DC, Dec. 5, 1970; White House Central Files, ND 18-3; Prisoner; [1969-1970]; Nixon Presidential Materials 275 ational Archives at College Park, College Park, MD.

George T. Bell, White House Staff, to Jim Keogh, Chief of the White House research and writing staff, Washington, DC, Oct. 28, 1970; White House Central Files, ND 18-3; Prisoner; [1969-1970]; Nixon Pressidential Materials; National Archives at College Park, College Park, MD.

George T. Bell, White House Staff, to Jim Keogh, Chief of the White House research and writing staff, Washington, DC, Oct. 28, 1970; White House Central Files, ND 18-3; Prisoner; [1969-1970]; Nixon Presidential Materials; National Archives at College Park, College Park, MD. 
The United States Government Responds

our involvement in Vietnam with assurances of the return of our men who are prisoners of war, or continuing our involvement in Vietnam until the prisoners are released?" Seventy-five percent thought the United States should remain in Vietnam until the prisoners were released. This strong support for the POW was a radical reversal of the ignorance and indifference the wives had encountered when they first began their public education efforts in the mid to late $1960 \mathrm{~s}$.

The Bottom Line Question: What Difference Did the Wives Make?

The surviving POWs finally came home in February and March of 1973 . The final section of this chapter confronts what must be considered a bottom line question in this dissertation: What difference did the wives' and other family members' political lobbying on behalf of their husbands and family members really make?

Questions of causality are always difficult to answer simply and definitively in historical research. A closer look at the information presented in the prior section provides one reason why this is so. This information clearly indicates that a wide rage of individuals and groups were putting pressure on the White House to keep the POW and MIA issue on the administration's agenda in negotiations with the North Vietnamese. In the absence of such broad-based support, it is doubtful that a small group of women and family members armed with only a compelling story and an improvised lobbying organization would have had the sort of clout to influence the White House. On the other hand, it is also unlikely that the POW and MIA issue would have gotten the attention of the public without the compelling story the women told and their dogged efforts to tell that story to anyone who would listen. 


\section{Chapter Seven}

Much the same thing could be said about the impact of key officials within the government. On the face of things, it certainly seems as if those with more direct access to power-e.g., Melvin Laird, Henry Kissinger, Alexander Butterfield, Richard Capen, Bob Dole, Al Haig — had much more influence on the POW and MIA issue than the National League did. Even Sybil Stockdale, while reflecting on the growing public support and eventual resolution of the POW issue, told me: "Most of the wives and mothers did not realize that White House influence was doing all of this. They thought they were doing it all by themselves." From Sybil's perspective, however, "Once they put their shoulders to the wheel, things began to happen."

Sybil, in fact, had a name for what happened once key government officials "put their shoulders to the wheel" for action: "That afterburner," she called it. Sybil's terminology is intriguing since afterburner is a technical term derived from military aviation that refers to a device incorporated into the jet engine's tail pipe that injects fuel into the exhaust gases, which in turn augments the thrust of the jet with greater power. When I asked Sybil to explain the term so I could understand clearly the meaning of her afterburner metaphor, she said: "You're taking off and then kick in the afterburner. The afterburner is the government backing."

Sybil indicated that she believed the "afterburner . . . kicked in when Mr. Melvin Laird made his announcement" about the treatment of the prisoners. This announcement, in turn, forced the White House to hold North Vietnam accountable for the well-being of the POWs and MIAs, "the power" of the White House, according to Sybil, "is incredible. It's mind boggling." She added: "Until you see that and feel it with your own eyes and heart you can't imagine what it is.... If you ever have the power of the White House 
The United States Government Responds

either against or for you ... if they ever decide to dump you ..." Sybil did not complete the sentence, but her meaning is quite clear.

Yet, once again, the story is a bit more complicated. Even Sybil's afterburner metaphor implies that some burning must occur before the afterburner kicks in, and it is obvious, in this case, that the wives and family members set the initial fire. As earlier chapters have noted, even before there was a National League, the members of the reluctant sorority were lobbying members of Congress, one of whom was Melvin Laird, who later became Nixon's Secretary of Defense. Earlier chapters also documented that Richard Capen, who lived in San Diego prior to moving to Washington DC to assume a high ranking position in Nixon's Defense Department, acknowledged to me that he first became aware of the POW and MIA issue through the actions of the POW and MIA wives in San Diego, and that Alexander Butterfield, the informal point person on POW and MIA issues within the White House staff, had ongoing interactions with the San Diego wives and, eventually, the formal leadership of the National League.

Furthermore, even once the afterburner kicked in because of Secretary Laird's very public reversal of the government's quiet diplomacy policy, the wives played what must be considered an essential supporting role in keeping the POW and MIA issue alive both in the government and within the public's consciousness. It may, indeed, have been the case, as Sybil Stockdale believes, that Laird's going public forced the White House to confront the North Vietnamese on the POW and MIA issue, but it also is the case that the wives and family members put a very personal face on the issue during their December, 1969 meeting with the President. And even if the President's seemingly sincere response to seeing this personal dimension of the issue was not enough to sustain a consummate 


\section{Chapter Seven}

politician's interest in the issue through the many years until it was resolved, the personal face was also visible to the public and helped generate the sort of public support that no consummated politician could ignore. Even Alexander Butterfield—who was relatively circumspect about the impact of the League's efforts and who argued that the League's efforts must be viewed in conjunction with many other groups' efforts-acknowledged that President Nixon knew the National League "could stir up or arouse interest here on the home-front by talking to Congressional reps, the media, etc."

Yet, the storyline about whether and how the wives impacted the POW and MIA issue is even more complex than the League applying political pressure, either directly or indirectly, and the government responding to this pressure. Over time, a sort of symbiotic relationship between government officials and the League's leadership developed out of a complex mix of motives. Richard Capen provided one of the more obvious examples of this symbiotic relationship: He noted that, after he was reassigned to the position of Assistant Secretary of Defense for Legislative Affairs, he traveled around the country to speak to joint sessions of State Legislatures. When he spoke at these various venues he "encourage[d] the wives to show up" to publicize the POW and MIA issue. (He noted that he and the wives also encouraged state legislatures to pass legislation that would waive tuition for children of POWs and MIAs at state institutions.)

Thus, the answer to the question about the wives' (and, eventually, the National League's) impact on the government's POW and MIA policy is as layered and complex as virtually all other answers to questions in historical research. Nevertheless, it seems certain that things would have played out differently had the wives not publicized their "compelling story"; had they not conducted their personal visits with government and 
military officials; had they not maintained their nonpartisan stance; had they not maintained media support through a conscious effort to avoid public relations slickness; and had they not maintained the sort of symbiotic relationship with the White House that resulted in the White House both using them for the White House's own political purposes yet also fearing them. 
Chapter Eight: A Personal Postscript-The Psychological Toll of Exercising Leadership in the Absence of Power

"I don't think the work took a toll. The situation took a toll."

Jenny Connell Robertson

"It is a difficult task indeed to take up your pen and write a letter to someone you love when you know not whether he is dead or alive."

Sybil Sockdale

The Psychological Toll

"New Year's Resolutions: (1) Survive every day."

Sybil Stockdale Diary Entry, January 1, 1973

The story told in the preceding chapters has been, more often than not, a story about performing in the public arena (and, also, in the early chapters, about learning how to act effectively in this arena). Every wife I interviewed, however, also spoke about a psychological and emotional toll exacted by their ordeal, and it quickly became apparent that the personal pain these women spoke of must become at least a postscript in the story I would tell about how a group of women, without political power, exercised leadership in the public arena.

I should add that all the women told me about the personal dimensions of their ordeal matter-of-factly: no one wallowed in self-pity. Phyllis Galanti, for example, told me she did not "remember it [the ordeal] being overwhelming" but she "definitely had [her] ups and downs." She credited a supportive community, the city of Richmond, her employer, a close family, and a strong faith for helping her through the ordeal. 
Some of the women even put a positive spin on their experiences. Jenny Connell Robertson, of example, characterized her ideal as a process of growing. She told me, "You don't have any strength at all when you're first in this situation. So to go from isolationist, no confidence, weakness, to finally feeling like your standing on your feetthat you can function in life ... Yes, that was monumental!"

Mary Winn, still quite prudent, posed a rhetorical question: "Don't all experiences have psychological fallouts?"

As mentioned before, the toll on Sybil Stockdale resulted in hospitalization and therapy. During my interview, she was quite honest and candid, and said she "was exhausted physically and emotionally and [that she] went right into a clinical depression. ... It was like I was swimming under water." One of the youngest wives, Bonnie Singleton, told me that the experience "was not glorious ... every moment of every day [it] was excruciating. ... That kind of emotional pain is just indescribable."

Three of the wives I interviewed spoke about the toll the ordeal had taken on their children. Sandy Dennison, for instance, noted "that war just did terrible things to families." More specifically, she said, "It was really very difficult . . . hard for the children, very hard, very, very hard!"

During my interview with her, Sandy indicated that she was one of the wives who had kept her children informed of her activities and the reasons she gave speeches and interviews. She said she felt the children needed to understand what they would see and hear from the television or read about her. Unfortunately, Sandy also had to prepare her children for the possibility that their father might not be coming home. Such preparation turned out to be appropriate since Sandy's husband did, in fact, die in captivity. Like 


\section{Chapter Eight}

millions of Americans in February and March of 1973, she watched as the prisoners returned to America. "Until all the POWs walked off the plane," she told me, "then I knew he wasn't coming back. ... you know, you live on hope a long time."

In the personal files of Sybil Stockdale, I came across a letter she wrote to a "new" POW wife, named Rene, dated February 12, 1967. The letter revealed the depth of emotional pain and heart wrenching agony associated with being a POW or MIA wife attempting to cope with the ordinary events of daily life. Sybil told Rene:

Children are a tremendous comfort in our circumstance but their guidance often seems beset with problems when there is no one to help with the decisions which invariably have to be made and cannot be postponed. It can be a dark hour when mother alone has to decide whether or not Johnny's educational problems really require the services of a professional psychiatrist or whether the orthodontist should be given the green light for an extensive and expensive program. Usually however, the tears come over the little things which are almost impossible to avoid. Having Johnny, age 6, come to you with tears in his eyes and ask "Is my daddy in jail because he did something wrong?" is enough to tear out a mother's heart but if the washing machine overflowed that morning and had to be bailed out with a pail and if the mail brought nothing but a letter from the bank saying your account was overdrawn and if you had just read an article in TIME saying the war would last another five to ten years, the world turns very dark indeed. So you splash a few tears into dinner that has to go onto the table anyway and into the tub of water for the baths which have to be taken and seek an elusive blessed sleep on a soggy pillow. The mood can come upon you as quickly as turning out a 
light bulb and unfortunately there is no way to predict how long it will last or when it will lift. But it does left [sic] and once again things seem to return to an acceptable level. Time itself $[$ sic $]$, is both your friend and your enemy. The longer you have been alone the more accustomed you are to your circumstance and although nothing gets any better, at least you are used to the way things are and know better what to expect. Once you have lived through every holiday, every birth, every anniversary and every endless Sunday afternoon, you are better able to do it the next time because you have been there before.

Those of us, like myself, have much more reason to hope and believe that someday we may enjoy the reunion to which we look forward with all our hearts. We have several who have every reason to believe that their husbands are prisoners and who are on the captured list but have never had any word from them at all since the last May Day was relayed by air. But we also have several from whom not even a May Day was heard and who just disappeared in darkness. I take off my hat to these girls who are so valiantly courageous and who know that the day reckoning may hold still another blow for them. It is a difficult task indeed to take up your pen and write a letter to someone you love when you know not whether he is dead or alive. ${ }^{277}$

Before concluding this discussion of the personal, psychological toll associated with being the wife of a prisoner of war or someone who classified as missing in action, I must reiterate that none of the women wished to nor did they dwell on this topic or wallow in the memories of the pain they had experienced. Sybil Stockdale's response is

${ }^{277}$ Sybil B. Stockdale, unpublished data, private collection. 


\section{Chapter Eight}

symbolic of the way all the wives I interviewed approached this issue. After reflecting and commenting on my question about the personal aspects of being a POW wife, she stopped abruptly, looked directly at me, and said: "Anyhow, that's enough of that."

\section{Some Closing Comments}

Sybil Stockdale closed her story, and our formal interviews, with reminiscences about the return of the men in 1973. She spoke about the celebrations that erupted across the nation and the White House gala for the prisoners and their families. For her, at least, the celebratory spirit was tempered by the knowledge that several husbands of dear friends remained unaccounted for. As she reflected on her contradictory feelings, she told me an interesting story about an encounter she had had with a member of the National League who hailed from a small town in Iowa. The woman, Mrs. Spencer, was the mother of LTjg Larry Spencer. Larry had spent seven years in captivity in Hanoi. Since Mrs. Spencer's son and Sybil's husband were both recovering at the same military hospital, she tracked Sybil down so they could talk.

Sybil recalled Mrs. Spencer asked her, "Mrs. Stockdale, what are you going to do now?" Sybil told her, "I don't know, Mrs. Spencer. I don't think anything is going to seem very grave, pressing, or worthwhile." Mrs. Spencer then told Sybil that she had "become quite famous . . . because [she had] been on television." Forthrightly, she told Sybil, "I'm not sure I can get along without this." Graciously, Sybil said, "Well, I think you just have to choose another cause and throw yourself into it. But, there will never be anything like this again." 
Chapter Nine: Discussion and Recommendations

It is customary in the final chapter of a dissertation to accomplish three things: first, to link dissertation findings to existing research and theory in the field; second, to discuss implications for practice; and third, to describe implications for further research. This chapter is organized around these three tasks. Additionally, and due to the historical nature of this dissertation and the uniqueness of the wives situation, this section will also address what obstacles the women had to overcome to influence policy makers and what their experience can teach about democratic participation.

\section{Linkages to Theory}

Before agreeing to participate in the study, several wives wanted assurances that their work — and their lives - would not simply be used to support or illustrate some academic theory. I provided the requested assurances, and, consequently, I have written this section (and complied with a traditional expectation of dissertation writing) with considerable caution and more than a little ambivalence.

In fact, the historical data reported in the previous five chapters are consistent with a number of prominent theories in Leadership Studies field, as well as with certain theoretical work emerging from the field of Public Policy. Consequently, this dissertation can be viewed as providing empirical support for a number of already well-established theories. This study, however, also extends and expands on this earlier work. Three particularly relevant theoretical works - two from the Leadership Studies field and one from the field of Public Policy_ - are discussed in this section.

Before proceeding with this largely theoretical discussion, however, I need to note that the material in the previous five chapters also provides the kind of understanding that 


\section{Chapter Nine}

theoretical abstraction can never provide and that only the "thick description" ${ }^{278}$ of historical research can offer. Consequently, readers are urged not to lose sight of the pragmatic, improvisational, innovative, and fluid activity that was described in previous chapters as they read the more theoretically oriented discussion below. Ultimately, this dissertation is about complex human beings who should never be transformed into social scientists' ideal types and whose remarkable accomplishments should never be merely subsumed under (and obscured by) theoretical constructs.

\section{Linkages to Ronald Heifetz's Leadership Without Easy Answers}

This research focused on how a group of women without formal positional power influenced government officials within the United States and, also, internationally. This focus is certainly consistent with the view of leadership articulated by Ronald Heifetz in Leadership Without Easy Answers. In this book, Heifetz defines leadership as an activity by anyone to mobilize people; the book emphasizes that the concept of leadership should not be associated only with those who have acquired formal positional power.

This study certainly speaks to the utility of Heifetz's theoretical efforts to decouple the concepts of leadership and positional power. It demonstrates that even within the large-scale national (and international) policy arena, those without formal positional power can mobilize people and have a major impact on public policy. They can exercise leadership, as Heifetz defines the concept, and can do so quite effectively.

In the process of demonstrating that "anyone" has the potential to exercise leadership, even on a national and international policy level, the study also expands our understanding of the sources of a leader's authority. The historical data reported in this

${ }^{278}$ Geertz, Interpretation of Culture, 3-31. 
Discussion and Recommendations

dissertation, in other words, not only gives flesh and blood reality to Heifetz's theoretical notion that authority is not merely a synonym for formal positional power. It also demonstrates that authority also can, at times, be rooted in personal relationships and the "compelling stories" a potential leader tells about these relationships. At least at an intuitive level, the leaders of the National League of Families seemed to understand this point. Their decision to keep the National League organization small by restricting membership to POW and MIA family members is evidence of this understanding.

Finally, this study also suggests the need for those whose authority is rooted in something other than formal positional power to recognize that they, in fact, have legitimate authority before they can act in ways that will lead others to recognize the legitimacy of their authority. Sybil Stockdale, for instance, advocated early on that the wives not transfer their authority on the POW and MIA issue to military and government officials by acquiescing to the government's so-called "keep quiet" policy. As was documented in the earlier chapters, Sybil unequivocally stated: "For the government to have the authority, the sole authority—heaven help us—no way!" Sybil-and the other wives I interviewed-knew that the men who were imprisoned in North Vietnam were their husbands, and they believed that this fact gave them a legitimate reason to have a say on the POW and MIA policy. To state this point another way: the wives understood that they were the ones operating from the front lines of the POW and MIA conflict, and their front-line status assured them of their right to tell their stories and become major players in the policy process.

In time, the wives felt sufficiently empowered to demand a meeting with the individual who held the ultimate positional-power job, i.e., President of the United States, 


\section{Chapter Nine}

within a specified period. By then, of course, many others had recognized the women's authority to exercise leadership on the POW and MIA issue, and, consequently, the "most powerful man in the world" acquiesced to the demand of a group of women whose authority was, to the end, much more personal and relational than positional.

To summarize, this study certainly provides empirical support for the utility of Heifetz's efforts to decouple the concepts of leadership and positional power and authority. But the study also extends Heifetz's theory of leadership by demonstrating both that personal relationships can be a source of non-positional authority and that those who wish to lead in the absence of formal positional power and authority must first recognize that they have authority and a right to speak on the issue. Thus, this study both supports and expands on the theory of leadership that Heifetz articulates in Leadership Without Easy Answers.

\section{Linkages to Heifetz and Linsky's Leadership on the Line}

Because it deals directly with the policy process, a more recent book by Heifetz and his co-author Marty Linsky, Leadership on the Line, is even more closely aligned with the findings of this study. Once again, the study reported here both provides empirical support for Heifetz and Linsky's largely theoretical (and quite prescriptive) discussion and extends many of Heifetz and Linsky's points.

In Leadership on the Line, Heifetz and Linsky discussed six aspects of thinking politically: find partners, keep the opposition close, accept responsibility for your part of the mess, acknowledge loss, model appropriate behavior, and accept casualties. Each of these six notions can be layered onto the data presented in the previous five chapters relatively comfortably, and, consequently, the historical data from this study suggest that 
Heifetz and Linsky have gotten things more-or-less right (or at least not dreadfully wrong). These data, however, also remind us that Heifetz and Linsky's six aspects of thinking politically can get a bit more complicated than the theorists indicate.

For example, according to Heifetz and Linsky the first directive for "thinking politically" is to find partners. The wives certainly found a large number of partnerseveryone from the very rich (and very generous Ross Perot), who financed many of the wives trips to the Paris peace talks; to the San Diego YMCA that offered free office space to the group before it became a national organization with a Washington DC office; to First Lady Pat Nixon, who invited Sybil Stockdale to ride on the first lady's plane (if Sybil chose to do so) when she flew between Washington DC and the Western White House in Southern California - and the wives' success most certainly had a lot to do with the partnerships that were formed.

But this study also suggests that partnerships can be a double-edged sword. Partners' agendas may overlap, but the overlap is seldom perfect. Thus, when partnership relationships are established, there is always the potential of being used to serve an agenda other than one's own.

In this study, for example, a review of government documents demonstrates that even when the government embraced the wives' agenda and, in a sense, became the women's partners, some government officials were not above using the wives and family members to build support for their Vietnam War policies, which some members of the National League did not personally support. To their credit, the wives were aware of efforts to use them and their public relations cachet, and they managed their relationship with the Nixon administration accordingly. For example, they were careful to keep their 
Chapter Nine

organization, the National League, officially non-partisan, but leaders of the organization also intentionally played a kind of Cheshire cat role that, in turn, kept administration officials guessing about what the members of the National League would do. In short, the wives allowed themselves to be used by the administration when it served their purpose, but they made it clear that their support could not be taken for granted.

The wives recognition of the potential downsides of partnerships also was evident in their parsing of the fund-raising issue. To this day, the wives insist that they did not engage in fund raising; they simply accepted donations. To some, this may sound like a meaningless distinction. To the women, however, the distinction is highly significant. It allowed them to retain a sense of independence and to stay disengaged from the need to accommodate the requirements of others, even while receiving the sort of financial support that was necessary to accomplishing their objectives.

There is little in the Heifetz and Linsky book about the potential complications that can arise when people embrace Heifetz and Linsky's first component of "thinking politically," i.e., finding partners. There is even less about how these complications might be managed. Thus, the material in the previous five chapters extends Heifetz and Linsky's theoretical discussion of what it means to think politically, even as it supports the claim that the Heifetz and Linsky book is generally on target. Much the same thing could be said about the other five components of the theory about political participation that Heifetz and Linsky articulate in Leadership on the Line.

Linkages to John Kingdon's Policy Entrepreneurs

In his book, Agendas, Alternatives, and Public Policies, John Kingdon wrote about policy entrepreneurs who, whether out of self-interest or altruism, sense problems 
Discussion and Recommendations

and then seek a solution to solve the problem. ${ }^{279}$ These entrepreneurs, Kingdon argued, have the ability to "soften up" the problem using speeches or other activities to focus attention on the issue that concerns them. Kingdon's theory proposes that policy entrepreneurs could influence the government's agenda if three conditions are met: first, the individual must has some claim to a hearing; second, the person must have political connections or negotiating skills that get the attention of policymakers; and third, and probably most important, successful entrepreneurs are persistent - their tenacity pays off. $^{280}$

Once again, there is consistency between an existing theory and the historical data presented in the prior chapters. Thus, the data presented in this dissertation can be used to empirically support a theory, in this case, a theory from the public policy field. As was noted above, the women had a clear claim to be heard, and it was this claim that was a primary source of their authority and influence.

In addition, some of the wives husbands were senior ranking military officers in prison, which created ready-made access to political and, especially, military leaders. To be sure, this access could be a bit of a mixed blessing because there was a tendency, especially in the military, for wives of officers to be perceived in certain ways. This notso-subtle bias, could be overcome, however, because of many of the women were well educated and had high social intelligence. Their decision never to cry in front of a public or military official is but one indication that they knew who they were dealing with and what needed to be done (or, in this case, not done) to be effective with these people.

\footnotetext{
${ }_{280}^{279}$ Kingdon, Agendas, Alternatives, Public Policies, 122. Ibid., 180-181.
} 


\section{Chapter Nine}

Finally, the wives were nothing if not persistent. Sybil Stockdale's ongoing attempts to arrange family members' first face-to-face meeting with the President - a meeting that appears to have resulted in a major shift in attitude on the POW and MIA issue within the White House-is one indication of this persistence. She simply did not take no for an answer.

Thus, this study supports the theoretical points articulated in the John Kingdon's book Agendas, Alternatives, and Public Policies, just as it supported the thinking on display in the two Leadership Studies texts discussed above. Once again, however, the story told here is much richer than the theory to which it so closely corresponds. Two examples of this richness should suffice.

First, with respect to persistence, it makes little sense to persist in doing things that are ineffective, and part of the women's success had to do with their shift in strategy in response to negative feedback. For instance, the wives' failure to interest the editors and writers of Look magazine in telling their personal stories became a valuable learning experience when the wives noted that the editors were at least somewhat interested in the fact that they had formed a formal organization. This observation was the impetus for Sybil Stockdale to (as she said) "wave [her] magic wand" and create a national organization.

The women also made adjustments in response to changes in the larger context. As the war dragged on and the prisoners did not return, Leaders of the National League recognized the need to adjust somewhat the League's longstanding commitment to nonpartisanship on the war issue. They allowed individual members to take sides as individuals. They also formed the Nonpartisan Political Action Committee, a group 
whose oxymoronic name signified both a shift in strategy but, also, that the group's nonpartisan stance had not been completely reversed. These compromises had two positive effects: first, they effectively managed disagreements about the Nixon administration's policies within the organization and, second, they signaled the White House that it really could not take the National League's neutrality for granted.

In short, the POW and MIA wives were nothing if not persistent. But they were also flexible. This leavening of persistence with flexibility allowed the wives to learn from their failures and permitted them to adjust to changes in both the external environment and the environment within their organization.

\section{Linkages Conclusion}

In this section, I focused on three major theoretical worksLeadership Studies and one from the field of Public Policy - that appear to be highly consistent with the findings of this study. The study, in fact, provides considerable empirical support for each of the theories. But the study also extends all three of the theories. Furthermore, even when extended and expanded, the theories discussed hereor any other theories, for that matter-can never completely accommodate the richness and complexity of the historical data presented in Chapters 4 through 8 .

\section{Implications for Practice}

The problem alluded to in the final sentence of the previous section is also a problem that writers of historical dissertations must manage when doing another task that dissertation writers are expected to accomplish in their final chapter: articulate a relatively clear and straightforward set of implications for practice. It is not that history has no practical implications. Nothing could be further from the truth. It is just that the 


\section{Chapter Nine}

practical implications that can be gleaned from reading history can become rather superficial and prosaic when separated from the contextual data that gave rise to them. It is the details of the historical story that tend to produce new understandings and suggest new possibilities for practice, much as the details of day-to-day experience lead us to learn new things and new ways of working. Indeed, good histories provide virtual experiences in places and times that we cannot encounter in our every day lives, and, as a result, they provide opportunities for "experiential" learning that extend beyond the direct experiences of learning of day-to-day life.

Nevertheless, my task, in this section, is to reduce the rich historical data that took four chapters to present to a list of relatively simple and straightforward implications for practice. I have reframed this task as providing a list of "lessons learned" from this study about how to provide leadership in the policy arena when one lacks both positional power and the sorts of resources that groups like big business and big labor have available. As readers review the list of lessons learned below, I urge them to recall the rich historical data from which the lessons were abstracted.

\section{Lesson \# 1: Do Your Homework}

The wives in this study were well educated and continued to educate themselves throughout the process on a number of pertinent issues. They also were astute observers who could figure out quickly what worked and what needed to be modified.

The women, for instance, actually read and studied the Geneva Convention Relative to the Treatment of Prisoners of War, as well as books about and related to Vietnam. Consequently, when they interacted with military and government officials, they could not be easily dismissed, even in an era when women-and especially military 
Discussion and Recommendations

officers' wives - were cast in stereotypical roles, roles that did not include the role of political activist.

Lesson \# 2: Size Matters; Resist the Organizational Urge to be Big

There is a tendency to assume that, organizationally, bigger is better, especially when a group is attempting to influence national policy. But it is clear that the wives would have never been able to form an organization that would have had the resources and political clout of, say, a major labor union. The women in this study needed to play a different sort of political game, and to "win" that game, the women needed a small, tightly knit organization. Thus, the decision to limit membership in the National League to family members of POWs or MIAs was obviously important.

Keeping the organization small meant that the organization required very little bureaucracy. Also, by staying small, the organization could continue to be held together by personal relationships rather than organizational structures. As a result, flexibility was maintained and morale remained, for the most part, high. The national organization, it might be argued, was merely an extension of Sybil Stockdale's dining room table writ large, and that was a good thing. Limiting membership in the organization to family members made this personal organizational environment possible.

\section{Lesson \# 3: Tell a Compelling Story}

Limiting the organization to family members of POWs and MIAs also was important because it meant that the organization and all of its members were able to tell a compelling personal story. As noted above, the women's authority ultimately was rooted in the personal story they were able to tell and the personal relationships in which their story was grounded. 
Chapter Nine

Lesson \# 4: Nothing is More Important than a Personal Visit

This fourth lesson was actually one of Sybil Stockdale's dictums and was a strategy that the wives and the national organization they formed used throughout the process they engaged in to lobby for the humane treatment of their husbands. The personal visit strategy was highly effective. It helped build a level of congressional support that the executive branch could not ignore, and Sybil Stockdale even used the strategy with the President of the United States. The family members meeting with the President, in fact, seems to have been an important turning point in garnering the administration's support for the issues the women had been championing.

\section{Lesson \# 5: Stay Focused/Remain Non-Partisan}

Another key to the women's success was that they remained focus on their objective: to promote the humane treatment of their husbands. At the organizational level, they did not allow themselves to lose focus by taking a position on the Vietnam War or on the administration's handling of the war. This non-partisan stance not only allowed the women to "stay on message"; it also meant that they were able to develop allies within both parties and among both hawks and doves.

As noted, the National League did modify its commitment to nonpartisanship as the war dragged on and frustrations within the organization continued to rise. But the group never totally abandoned its commitment to nonpartisanship, and, thus, the organization, at least, never lost sight of its objective and never obscured its central message. 
Discussion and Recommendations

Lesson \# 6: Form Partnerships, but Keep Partners at Arms-Length

The members of the National League had generous and powerful allies, including the Nixon administration. But they were careful to maintain an arms length relationship with allies. They refused to solicit funds and would only accept donations with no strings attached. In addition, the women did not allow themselves to be taken for granted. Indeed, one benefit of the National League's softening of its commitment to nonpartisanship in the latter years is that the organization kept the Nixon administration guessing about what the National League might do and ensured that the Nixon administration officials would continue to attend to and attempt to accommodate the women's concerns.

\section{Lesson \# 7: Don't get Slick/Avoid Public Relations Professionals}

Undoubtedly one of the best pieces of advice the women received — and which they followed to the end-was to avoid hiring a public relations professional to plead their case with the media and the public. Their very lack of public relations savvy turned out to be a highly effective public relations "strategy." The media loved them precisely because they were not slick. Indeed, as has already been noted, their authority was rooted in personal relationships and the compelling story they told of these relationships. Any hint of slickness would have undermined this authority at least with the somewhat jaded Washington press corps and probably with the general public, as well.

\section{Recommendations for Future Research}

Based on the research and what it has revealed, three types of studies are recommended. 
Chapter Nine

Studies of Other Influential Individuals or Groups on the POW/MIA Issue

All research studies-and certainly all-historical research which, by design, sacrifices breadth for depth-can only tell a part of the story. The focus here has been on a group of wives. There was certainly good reason to focus on this group since members of this group formed and became leaders in the National League. But there were other actors-other wives from other parts of the country, as well as mothers, fathers, sisters, and brothers of POWs and MIAs - who played an important role in keeping the POW and MIA issue before the public. There is a need to document their stories, as well. Studies of Other Groups That Have Exercised Leadership on Other Public Policy Issues in the Absence of Positional Power/Constructing Grounded Theory

There is also the need to conduct studies of other groups and individuals who lacked formal positional power or the sorts of resources normally associated with being able to influence the policy making process yet still provided leadership on a range of public policy issues. Once a number of studies on a wide range of policy issues have been completed, an effort to should be made to compare and contrast the findings of different studies with an eye toward building grounded theory about exercising leadership in the policy domain in the absence of either positional power or a rich resource base.

Oral History Project

In order to preserve the wives' and family members' experience in a relatively unmediated form, an oral history project should be undertaken by the either the Richard M. Nixon Library, Gerald R. Ford Library, or a prominent university or college. This project should also involve the children of POWs and MIAs, who, undoubtedly, have their own unique stories to tell. 


\section{Conclusion}

Today it can seem as if special interest groups, political action committees, lobbyist, and financial contributors muffled the voice of the American citizen. Indeed, many Americans feel powerless and marginalized, unable to influence their government despite the country's continuing rhetoric about democratic participation.

This dissertation has presented a narrative to counter the current malaise. It suggests that, at least under certain circumstances, citizens without the trappings of power can have a significant influence on government policy and world events. The story of how a group of wives who first gathered around a table in San Diego, California, got the attention of the President and other world leaders is a story about persistence, the exercise of intelligence, and learning through experience. It is also a story about the power that a compelling narrative can have, especially when those telling the story are, themselves, the very embodiment of the story's message.

Though written about men, the words of Walter Isaacson and Evan Thomas are most apropos for concluding this dissertation about a stalwart group of women who managed to exercise national leadership in the absence of formal positional power: "For better or worse, they were positioned by the chance of history to have consequence far beyond their individual identities. Secure in their common outlook, empowered by the bonds of trust, they met the challenge of a demanding new age. In their sense of duty and shared wisdom, they found the force to shape the world." ${ }^{281}$

\footnotetext{
${ }^{281}$ Isaacson and Thomas, Wise Men, 741.
} 
1. The interview being granted is for Steven Lee Smith's doctoral dissertation at the University of San Diego, San Diego, California. The purpose of this form is to grant consent to being interviewed as it relates to:

a. The experience of being the spouse of a Vietnam Prisoner of War (POW) or Missing in Action (MIA) and the personal actions taken to influence American policy.

b. The experience of being associated with or knowing the activities of the wives of POWs or MIAs to change national policy related to the treatment of POW and MIAs in North Vietnam.

c. The experience of being associated with or knowing the activities within the Nixon Administration's involvement with POW and MIA matters and activities related to the wives of POW and MIAs and the National League of Families.

2. Participation does not involve any physical or legal risk. Social or professional risks are minimal since participants can choose what to disclose.

3. Some participants might experience a degree of anxiety in being asked to recall personal events and are always free to move away from any topic, terminate the interview at anytime, or be referred to a counselor.

4. The project seeks to increase understanding about leadership without authority and power as it relates to the influencing of national policy. The participant, therefore, is able to engage in self-reflection and dialogue via an oral history about personal and historical events from 1965 to 1973.

5. Participation is voluntary. The participant can discontinue the interview at any point without prejudice. If a participant decides to withdraw from the study, data collected prior to withdrawal will not be used.

6. The participant will have the opportunity, prior to the interview, to review the content of the questions. Participants will be provided the opportunity to review the transcript and note material "off the record."

7. Participants will be asked to take part in an interview that will last approximately 1 to 3 hours. If necessary, for clarification or additional information, phone calls will be made to the participant.

8. Due to the historical nature of this research, participant names will be used in the dissertation. However, if a participant determines certain statements are best kept confidential, confidentiality of participants and responses will be granted and the researcher will do his best to disguise the identity of the speaker. 
9. The interview will be tape-recorded, with the tape and transcript kept in a locked filing cabinet located in the researcher's home.

I understand the above explanation and I give consent to my voluntary participation in this study.

Signature of Subject

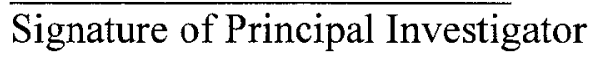

Date

Date 
1. Would you tell me what is was like being the wife of a POW and MIA?

2. Would you tell me about your involvement with the National League of Families? Or, How would you describe your involvement with the National League of Families?

3. What National League activities or events did you plan or participate in?

4. What type of strategy did the National League use to influence national policy on POW and MIA issues? Did you help formulate strategy?

5. What events or activities of National League do you consider having the most influence on governmental officials?

6. Were there any specific factors influential in the choice of strategies?

7. Do you remember encountering obstacles from the government or military officials? How did you deal with them?

8. Did you ever feel the experience was taking a psychological on you? How was that handled?

9. What specific and important events do you recall chronologically? 
Appendix C Survey Questionnaire: Government or Military Officials

1. What was your position within the Nixon Administration?

2. Would you tell me what you knew about the activities of the wives of POW and MIAs and the National League of Families?

3. What was the level of your involvement with the wives of POWs or MIAs?

4. To your knowledge how influential were the wives of POWs or MIAs within the Nixon Administration?

5. To your knowledge how influential was the National League of Families of Prisoners of War and Missing in Action?

6. Did the strategy of the National League influence national policy toward POW and MIA issues?

7. Were there any specific actions or events from the wives or the National League that you remember as being most influential within the Administration?

8. In your professional opinion and based on your recollection do you feel the support of the Nixon Administration for the wives and National League was based on a moral imperative or one of political necessity?

9. What specific and important events do you recall chronologically? 
Appendix D Geneva Convention Articles Relative to the Treatment of Prisoners Cited by

Wives

Article 2-In addition to the provisions which shall be implemented in peace time, the present Convention shall apply to all cases of declared war or of any other armed conflict which may arise between two or more of the High Contracting Parties, even if the state of war is not recognized by one of them.

-Although one of the Powers in conflict may not be a party to the present Convention, the Powers who are parties thereto shall remain bound by it in their mutual relations. They shall furthermore be bound by the Convention in relation to the said Power, if the latter accepts and applies the provisions thereof.

- The provisions of the present Convention constitute no obstacle to the humanitarian activities which the International Committee of the Red Cross or any other impartial humanitarian organization may, subject to the consent of the Parties to the conflict concerned, undertake for the protection of the prisoners of war and for their relief.

Article 10-If protection cannot be arranged accordingly, the Detaining Power shall request or shall accept, subject to the provisions of this Article, the offer of the services of a humanitarian organization, such as the International Committee of the Red Cross, to assume the humanitarian functions performed by Protecting Powers under the present Convention.

Article 13-Prisoners of war must at all times be humanely treated. Any unlawful act or omission by the Detaining Power causing death or seriously endangering the health of a prisoner of war in it custody is prohibited, and will be regarded as a serious breach of the present Convention.

- Prisoners of war must at all times be protected, particularly against acts of violence or intimidation and against insults and public curiosity.

Article 15-The Power detaining prisoners of war shall be bound to provide free of charge for their maintenance and for the medical attention required by their state of health.

Article 17-No physical or mental torture, nor any other form of coercion, may be inflicted on prisoners of war to secure from them information of any kind whatever. Prisoners of war who refuse to answer may not be threatened, insulted, or exposed to any unpleasant or disadvantageous treatment of any kind.

Article 18-At no time should prisoners of war be without identity documents. The Detaining Power shall supply such documents to prisoners of war who possess none.

Article 25-The premises provided for the use of prisoners of war individually or collectively, shall be entirely protected from dampness and adequately heated and lighted, in particular between dusk and lights out. All precautions must be taken against the danger of fire.

Article 26-The basic daily food rations shall be sufficient in quantity, quality and variety to keep prisoners of war in good health to prevent loss of weight or the development of nutritional deficiencies. Account shall also be taken of the habitual diet of the prisoners. 
Geneva Convention Articles Relative to the Treatment of Prisoners

Article 29-The Detaining Power shall be bound to take all sanitary measures necessary to ensure the cleanliness and healthfulness of camps and to prevent epidemics. Article 125-The special position of the International Committee of the Red Cross in this field [humanitarian aide] shall be recognized and respected at all times. 
Appendix E Advice to Potential Prisoner of War Families ${ }^{282}$

Subject: Advice to potential prisoner of war families

From: Public Information Officer, ComNavAir Pac Staff

By: Sybil B. Stockdale

A. Method of Notification

1. Every effort will be made to notify the next of kin personally. If this is not possible next of kin will receive a telegram. This telegram will give the name of someone in the State Department who can be referred to for further information concerning the prisoner, etc.

2. In some cases, in order to "beat the press" the next of kin will be notified by telephone. It is considered the better method than having next of kin hear the news via public address medium.

B. Immediate recommended action by next of kin

1. Parents of the prisoner and parents-in-law of the prisoner should be notified by telephone. They should be warned not to release any information about the prisoner and not to be interviewed by the press concerning his background, etc.

2. Next of kin should engage someone to act as her telephone operator. This person should be instructed to accept no calls from foreign cities outside the limits of the United States. No information of any kind should be released about the prisoner or his family. All such inquiries should be referred to the Public Information Officer at AirPac headquarters.

3. The standard answer to all news agencies should be "Mrs. has no comment for the press at this time".

(A) The reasons for maintaining press silence are in the best interests of the prisoner. Any information other than name, rank, serial number and age can be skillfully used in psychological warfare to coerce the prisoner to aid the Communist propaganda program.

(B) Pictures of the family of the prisoner can also be used as coercion and thus be detrimental to the welfare of the prisoner.

C. Treatment of the Prisoner

1. Prisoners at present are being well treated and authorities have every reason to believe that this condition will continue. If present conditions do continue the prisoner will probably not have to undergo brutal torture.

2. The family of the prisoner can expect that eventually the Communists will announce that the prisoner has signed some paper which he would not sign under normal circumstances. The family should not comment on this announcement as the information is probably correct. All prisoners to date have signed some paper which they would not be expected to do unless victims of psychological warfare.

${ }^{282}$ Sybil B. Stockdale, unpublished data, private collection. 
3. Any medals awarded the prisoner in his absence should be accepted by the family of the prisoner when they are offered.

4. The family may expect to see pictures of the prisoner in various compromising roles released by the Communists for propaganda purposes. Comments about such pictures only help serve the purposes of the enemy.

D. Communication with the prisoner

1. The family will be given an address through which they can write to the prisoner.

(A) All letters should be of a very general nature. Children or friends should not be mentioned or referred to other than in general terms.

(B) Families are warned to delete terms of endearment from their mail as these an be used to the prisoner's detriment.

(C) No letter sjpi;d be wrotten [sic] that one would not be able to tolerate if printed on the front page of any newspaper.

2. Mail may eventually be received from the prisoner and will probably be forwarded through the International Red Cross. These letters will also be of a very general nature and will not contain any of the usual terms of endearment used by the prisoner. delivery.

3. Packages may be mailed to the prisoner but there will be no assurances of

E. General expectations for the captivity period.

1. The Casualty Assistance Officer will call on the family and give aid and advice regarding the financial status of the next of kin. It is most strongly urged that all next of kin have an adequate allotment made out to her before the officer departs the continental limits of the United States.

2. The family can stay best informed about the welfare of the prisoner of they live in the home port of the prisoner.

3. News agencies may from time to time have information about U.S. prisoners. It is advisable to watch major news programs on television regularly, to read the daily paper and such news magazines as TIME, U.S. NEWS AND WORLD REPORT, etc.

4. There is little chance that the prisoner will be able to escape. His release should be expect only through negotiation or through peaceful settlement of differences with enemy forces.

(A) Families are strongly urged not to intercede on behalf of the prisoner without State Department approval.

(B) Independent intercession on the part of the individual could seriously damage negotiation being conducted in behalf of the prisoner by the State Department. 
Appendix F Additional References on Inhumane Treatment of the Prisoners

Additional references regarding inhumane treatment of the prisoners after 1966 include the following:

- Sybil Stockdale, under the guidance of Naval Intelligence, participated in covert communications with her husband. In a letter she received from her husband, dated January 2, 1967, and later deciphered by naval authorities, she was made privy to its full contents. In coded form her husband had written: "Experts in Torture Hand and Leg Irons 16 hours a day." In Love and War, James B. and Sybil Stockdale (New York: Harper and Row, 1984), 207.

- In a Department of State publication (referred to as a White Paper), Viet-Nam Information Notes, Number 9, August 1967, confirms "there are increasing indications of the deliberate mistreatment of prisoners" and that the record of humane treatment to American POWs by the North Vietnamese government "has been deplorable." Department of State, Viet-Nam Information Notes, Number 9, August 1967. Sybil Stockdale, unpublished data, private collection.

- In a letter to Sybil Stockdale from Congressman Olin E. Teague (D-TX), Mr. Teague informs her about his trip to Vietnam and subsequent letters he has written to the Secretaries of Defense and State "to find out just what is being done for our boys who are captured by the North Vietnamese." He also told her "that until the North Vietnamese are willing to abide by the provisions of the Geneva Convention, we cannot learn the real truth about the treatment of these prisoners. From Olin Teague, Congressman, to Mrs. James Bond Stockdale, October 10, 1967. Sybil Stockdale, unpublished data, private collection.

- Washington Post, columnist George C. Wilson wrote about the "brutal treatment and torture of American prisoners." George C. Wilson, "Freed Prisoners of War Tell Of Hanoi Brutality, Torture," New York Times, September 3, 1969. 
Appendix G How to Handle Your Contacts with the Media ${ }^{283}$

HOW TO HANDLE YOUR CONTACTS

WITH THE NEWS MEDIA

A basic "primer" of information

and suggestions, prepared by:

THE NATIONAL LEAGUE OF FAMILIES

OF AMERICAN PRISONERS AND MISSING

IN SOUTHEAST ASIA

1 Constitutional Ave., N.E.

Washington, D. C. 20002

\section{INTERVIEWS}

Generally speaking, there are two basic situations in which you may be interviewed by the news-media:

1 - A reporter has contacted you to ask for an interview, or

2 - You have contacted a reporter or editor, on your own, to suggest an interview.

If either of these contacts is a telephone-contact, you should comment that you would be happy to meet with the newsman either in your own home or at his office --- by try to arrange for a personal meeting --- this is much more satisfactory than a telephone interview where the reporter cannot see or relate to you as an individual.

Most interviews probably will focus initially on your personal circumstances, but regardless of whether the reporter asked for the interview or you asked for the interview, remember that you are not limited by the questions the reporter asks.

You should think of every interview as an opportunity to discuss all facets of the prisoner-issue. In other words, this is your opportunity to help inform and educate the public and to stir some form of public response.

${ }^{283}$ Phyllis Galanti, unpublished data, private collection. 
During the interview, for example, even though the reporter has not asked you about mail-delivery (or if he has discussed the subject only in a limited context), don't hesitate to bear-in on the issue. Try to make the reporter understand that he has a responsibility to bring the mail-issue into sharp focus. You can say to him, for instance: "Nothing you write will tell the whole story unless you make your readers understand the terrible communications problem." This, or some similar statement, should open the subject to detailed discussion.

The same is true of all other aspects of the overall problem. You can open discussion on anything you feel a strong need to talk about.

Here are some further examples of the kind of statements you can make to the reporter to further stimulate his interest after the interview begins to warm-up a little and you are both more relaxed and comfortable with each other:

. "I suppose you want to know some of the facts and figures about the number of men who are missing or captured." as prisoners."

. "You probably wonder how we've been able to identify the men who are listed purposes."

. "I imagine you're aware of the way the prisoners have been used for propaganda

. "Have you heard about some of the experiences that have been related by the few men who have been released or escaped?"

Don't hesitate to appeal to the reporter to highlight certain facts. Frequently, if you make such an appeal, the reporter may feel obligated to discuss the specific matter you consider so important.

One example already has been cited, concerning mail-delivery. When you say to the reporter, "Nothing you write will tell the whole story unless. . ", you are, in effect, demanding something of him, but in a nice way. Examples:

The same approach can be taken on a number of other topics, in a variety of ways.

. "I certainly hope you will stress such-and-such."

. "Frequently, this information doesn't get printed, so please try to include some discussion of it in your story."

. "It's so important for the public to understand such-and-such. If you could just help educate them to this fact, you really would be performing an invaluable service to the families of these men."

The variety of appeals is almost infinite. Don't over-use them, but don't hesitate to make four or five such pitches to the newsman, threading them her and there throughout the interview. And you may want to summarize them near the end of the interview by saying something like this:

"I've mentioned how important I think it is for the press to inform the public about the truth of the letters-situation, the horrible conditions of captivity, the heartless way the prisoners have been used as propaganda hostages (etc). Whatever else you write, please try to help your readers understand these points."

Attached are a number of "information sheets" the League believes will be helpful to you in conducting interviews. These will be supplemented or up-dated from time to time as the need arises. 
Appendix H Remarks of the President at the Annual Meeting of the National League of

Families of American Prisoners and Missing in Southeast Asia ${ }^{284}$

FOR IMMEDIATE RELEASE

OFFICE OF THE WHITE HOUSE PRESS SECRETARY

SEPTEMBER 28, 1971

the white house

remarks of the president

at the annual meeting of the

national league of families

of American prisoners and

missing in southeast asia

statler-hilton hotel

AT 7:15 P. M. EDT

Mrs. North, Mr. Secretary, all of the distinguished guest who are at the head table and all of those who are in this audience.

I have spoken in this room many times over the past, believe it or not, 24 years, starting as a Congressman. I can assure all of you that this brief remark that I will now address to you is spoken more from the heart, I think, than anything I have ever said before.

The Secretary of Defense - and I have had an opportunity to read his remarks and endorse them - will address you later. He will tell you what we have been doing, what we are doing, what we hope to do with regard to the great objective in which all of you and all of us are interested, and that is obtaining the release of all of our POW's and missing in action wherever they may be in Southeast Asia.

But I wish to underline what the Secretary will tell you by indicating the personal commitment of the President of the United States. As you can imagine, whoever holds the office of the Presidency cannot take upon himself all of the various assignments that come across his desk. Much must be delegated.

284

Richard Nixon, President of the United States, to the Annual Meeting of the National League of Families of American Prisoners and Missing in Southeast Asia, Washington, DC, Sep. 28, 1971; White House Special Files; Ronald Ziegler; Vietnam Prisoners of War I, 02-19, [2 of 2] Nixon Presidential Materials; National Archives at College Park, College Park, MD. 
I want each and every one of you to know, however, that from the time in the White House Library, at Christmas time, 1969, I met a group of wives and one mother of some POW's and missing in action, from that time, as the Secretary of Defense can tell you, and the Secretary of State can tell you, I have considered the problem of obtaining the release of our POW's and missing in action as being one that has presidential priority.

I can assure you that every negotiating channel - and now I say something here that I am sure all of you will understand - including many private channels that have not yet been disclosed, have been pursued, are being pursued and will be pursued.

I can assure you that with regard to this problem, that whenever any matter comes to the attention of the Secretary of Defense, or the Secretary of State, from a Senator or Congressman or the rest, it is brought to my desk and we run out the lead, whatever it may be.

You know the tragedy we have found so often - hopes are raised and then dashed, because we are dealing here with a savage enemy, one who has no concern for humanitarian ideals.

But on the other hand, we believe that it is essential to check every possible lead; we don't care where it comes from. We are doing that.

I have personally ordered that and we will continue to do so, and I believe that we will eventually succeed in our goal. That is my commitment that I make to all of you.

Now, I have delayed your dinner too long, but I would like to add one other rather personal note. Many times when I travel around the country, people - particularly young people in school - will say, "You know, Mr. President, that must be a terribly awesome responsibility to serve as President of the United States." And people sometimes feel that all of the great burdens of the world are on the shoulders of the President and that the responsibilities are indeed awesome. I would be less than candid if I were not to say that the responsibilities are heavy.

But let me tell you something: Any day that I sometimes feel that it has been a rather hard day and that I have had to make some real tough decisions, and I haven't' had very much support, and any time I begin to feel a bit sorry for myself, I think back to that day just before Christmas in 1969.

I think of airports where children have come up and said, "My daddy is missing in action." I think of the wives who I have seen and the mothers and the rest. I think of their courage and what they have done and what they have given for their country, and then I realize my job isn't all that hard. down.

I am just so proud of how great you have been and I am not going to let you

END (AT 7:22 P.M. EDT.) 
Appendix I Address by the Honorable Melvin R. Laird ${ }^{285}$

HOLD FOR RELEASE

UNTIL 7:00 PM (EDT)

TUESDAY, SEPTEMBER 28, 1971
No. $828-71$

OXford 7-3189 (Copies)

OXford 5-0192 (Info)

Address by The Honorable Melvin R. Laird, the Secretary of Defense at the annual dinner of the National League of Families Of American Prisoners and Missing in Southeast Asia, Washington, DC, Tuesday, September 28, 1971.

In my many meetings with the wives, parents and other family members of our Prisoners of War and missing in action around the country, I have come to know many of your personally. To be with you here this evening is again an inspiring and humbling experience.

You have won the admiration of the nation and of a great part of the civilized world because you have borne uncertainty and loneliness with dignity and courage.

I pray that you will continue to have the inner resources to maintain that dignity and that courage until the day on which uncertainty ends and on which those who are prisoners are reunited with their loved ones. I want tonight to reaffirm my pledge to you that we will not forget your husbands, your sons, your fathers - and, we will not forget you.

Each of you is aware that the U.S. Government was following a policy of virtual silence on the issue of prisoners of war and the missing until early in 1969. This former approach was followed, I know, not because of lack of concern for the men who were in prison or whose fate was unknown. On the contrary, it was assumed that the welfare of the prisoners would be best served by public silence.

A change of policy was effected after President Nixon entered the White House. We felt that the enemy's violation of the Geneva Convention should not continue to pass unnoticed. We were disturbed by Hanoi's failure to account for our servicemen whom they held and for those who they knew had died in territory under their control in North Vietnam, South Vietnam, and Laos. We were incensed by reports of inhumane treatment of Americans.

And so I recommended that a different policy be pursued and that we discuss the humanitarian issue of prisoners of war and missing in action, openly, candidly, forcefully, and repeatedly.

As you know, I have made it a point on my trips to Europe and even on my last trip to Vietnam, to make a stop in Paris for the exclusive purpose of meeting with our delegation on this issue. Also, I have sought, whenever possible, in any meeting with my fellow Defense Ministers or other foreign government officials to discuss it and to seek the active support of other governments for our efforts to return theses men to their families. I will continue to do so every chance I get.

285 Melvin R. Laird, Secretary of Defense, to the Annual Meeting of the National League of Families of American Prisoners and Missing in Southeast Asia, Washington, DC, Sep. 28, 1971; White House Special Files; Ronald Ziegler; Vietnam Prisoners of War, I, 02-19, [2 of 2]; Nixon Presidential Materials; National Archives at College Park, College Park, MD. 
The President of the United States, our Commander-in-Chief, similarly has made this topic a priority item on the agenda in his discussions with leaders around the world, and he will continue to do so.

I need not remind you that President Nixon has made far-reaching proposals at the negotiating table in Paris, including specifically the immediate and unconditional release of all prisoners of war. That proposal was perhaps the most forthcoming ever made on prisoners of war in history. Yet, the other side has refused even to address it.

I believe that whatever the frustrations, whatever the uncertainties, we jointly should continue our policy of focusing world attention on our prisoners of war and the missing in action.

As long as Americans are held prisoners in Southeast Asia, as long as Americans missing in action have not been properly accounted for, our efforts must continue to keep this issue before the public in our own country and in the rest of the civilized world and to reinforce the demand for justice for these men.

We must continue unceasingly to demand that the rights of prisoners of war under the Geneva Convention be respected. We must continue to call attention to Hanoi's violation of those rights.

The Geneva Convention requires that prisoners be humanely treated and protected. This provision has been consistently violated. Among other things, the enemy paraded prisoners in the streets, forced them to make statements, and used them for purposes of propaganda.

The Geneva Convention requires that neutral inspection of prisoner camps be permitted, including interviews of the prisoners without witnesses in attendance. The enemy has never permitted such inspection or such interviews.

The Geneva Convention requires that the names of all prisoners be released promptly. Such names as the enemy has released have not been released promptly nor through regular channels. And its lists have not been complete. No list of prisoners held in South Vietnam and Laos has been furnished.

The Geneva Convention requires notification of deaths in captivity and full information on the circumstances and place of burial. The enemy has not furnished any information about circumstances of death and place of burial. There is strong ground for doubt that its list of the deceased is accurate or complete.

The Geneva Convention requires that prisoner of war camps be marked clearly and their location be made public. The enemy has not marked its camps nor divulged their location.

The Geneva Convention requires that the seriously sick and wounded be repatriated or interned in a neutral country. The enemy has refused to comply with this provision.

The Geneva Convention requires that prisoners be permitted to send at least 2 letters and 4 cards a month. The average has been 2 or 3 letters a year and none at all from some prisoners. Only one letter has been received from a prisoner held in South Vietnam, and none from prisoners in Laos. I am deeply disturbed that after a marked increase in the mail received from prisoners last year, this year's trend has gone down. We have worked through international postal contacts to try to establish special channels for prisoner mail to no avail. In every instance, North Vietnam has rebuffed the efforts of 
our intermediaries. Most recently, earlier this month, the North Vietnamese stated they prefer the present arrangements.

The Geneva Convention requires that sufficient food must be given to prisoners. Yet, all of the released prisoners have been found to be underweight and suffering from malnutrition.

The Geneva Convention requires that prisoners not be held in close confinement. Yet, the enemy has held some men in solitary confinement for years.

The list of continuing injustices impels us to persist in our efforts to see that Americans who are prisoners anywhere in Southeast Asia are accorded all the rights they possess by the Geneva Convention. We will persist in our efforts to obtain full information about the missing. We are not satisfied that any list so far released of those held prisoner and of the deceased is complete.

We stand by all the proposals we have made relating to exchange and release of prisoners. We urge particularly that the sick and the wounded be released immediately.

At this convention, you have wisely given careful attention to the problems of readjustment which will be faced when these men return home. It is important to plan now to meet these problems. I want to assure you that the Department of Defense and other agencies of government want to do everything we can to help you meet this challenge.

Let me deal briefly with the varying interpretations of the enemy's Seven Points presented at the Paris negotiations on July 1 of this year. There are many Americans who have claimed on the basis of some direct or indirect contact with North Vietnamese that Hanoi is prepared to be flexible on the issue of separating the release of the prisoners from the other issues. Yet, whenever our delegation I Paris has pressed Hanoi's representatives for a clear-cut explanation of Hanoi's stand, they have received no response or a response veiled in ambiguity.

Among the questions of particular concern to you which Hanoi's representatives refuse to answer are these:

- Does the release of prisoners mean all prisoners - or only those whom Hanoi has admitted it hold in North Vietnam? What about the other American prisoners including those held in South Vietnam, Laos, or elsewhere? When and how and where will release take place?

- What about the missing? Will they be accounted for? Without such an accounting, we cannot know whether any list of prisoners is complete.

At the time of the $120^{\text {th }}$ plenary session of the formal talks, the North Vietnamese had met about 130 times with various unofficial [sic] American delegations. These meetings have produced in our own society much misleading speculation about the war, the Paris talks, and the prisoners of war issue. In fact, Hanoi has never said to any one authorized to negotiate for the United States that the prisoners will be released if American troops withdraw, and, of course, there are other conditions which they want fulfilled.

On September 16 the North Vietnamese restated their seven point peace plan in the hardest terms, apparently repudiating the reports made by some Americans who see flexibility in Hanoi's propaganda.

Hanoi's inflexibility and changing signals, coupled with its failure to abide by the most rudimentary humanitarian standards, have led to unproductive results. We shall 
continue to press urgently for a full explanation of Hanoi's position, but we will not accept any proposition which is not clearly in the interests of this nation or of the prisoners themselves.

I wish I could say that I fully appreciate the anguish that each of you has undergone and continues to bear. Yet I realize that no one but you who are separated from your loved ones can know how hard it is to wait without knowing when the waiting will end. As I said at the outset, you and your loved ones are in our thoughts and in our prayers. We pray that you will continue to have the strength to hold fast to the conviction that the waiting will end - and it will.

Every resource of you government will be employed to speed the day when the waiting ends. Our efforts on behalf of the prisoners and the missing and on your behalf will not flag.

If together we continue to persevere, to remain united in purpose, to continue to keep the question of the prisoners and the missing high on the list of international priorities, we will achieve the objective for which we have been working. We will learn what has happened to the missing. And together we will welcome back our men. 
Appendix J National Week of Concern for Americans Who Are Prisoners of War or

$$
\text { Missing in Action }{ }^{286}
$$

National Week of Concern for Americans Who Are Prisoners of War or Missing in Action

Proclamation 4115. March 10, 1972

By the President of the United States of America a Proclamation

1,623 American servicemen and some 50 U.S. civilians are now either missing in action or being held captive by North Vietnam and its allies. At the end of this month, the first men to be taken prisoner will begin their ninth year in captivity. This is the longest internment ever endured by American fighting me; it is also one of the most brutal.

The POW and MIA story of this long and difficult war is a tragic one:

The enemy continues adamant in his refusal even to identify all the Americans being held. He continues to flout the Geneva Prisoner of War Convention which establishes minimum humane standards for treatment of prisoners-a treaty to which North Vietnam is a signatory, just as are South Vietnam and the United States and 128 other nations. He continues to block impartial inspection of the prison camps. He continues to deny repatriation for seriously sick and wounded prisoners. He continues to ignore the prisoners' right to regular correspondence with their families.

And so those families suffer in spirit hardly less than their men suffer in the flesh. They live in a nightmare of unremitting anguish and gnawing concern. Many cannot even know whether their loved ones are still alive; those who do know this much, must live with their additional knowledge of the cruel conditions in which the prisoners exist.

Each new chapter in this outrage has stiffened the American people's determination to see justice done. We have stood and will continue to stand united as a nation in our concern and compassion for the prisoners and missing men. We mean to see this matter through.

Concern for the prisoners' plight, moreover, has spread to the people of goodwill around the world — and we may be confident that their humanitarian efforts, though so far rebuffed as callously as our own, will still continue as steadfastly as our own.

The United States has spared no effort—by diplomacy, by negotiation, by every other means - to secure fair treatment of our captive sons and brothers and to obtain their ultimate freedom.

As we set aside a special week of national concern for this continuing tragedy, and a special day of prayer for its resolution, we do so with a determination to persist in this effort-for principle, for peace, for the sake of these brave men and their parents and brothers and sisters and wives and the children some have never seen.

${ }^{286}$ Richard Nixon, President of the United States, to Proclamation 4115, Washington, DC, Mar. 10, 1972; White House Special Files; Ronald Ziegler; Vietnam Prisoner of War, I, 02-19; Nixon Presidential Materials, National Archives at College Park, College Park, MD. 
Now, Therefore, I, Richard Nixon, President of the United States of America, as requested by the Congress in Senate Joint Resolution 189, do hereby designate the period of March 26 through April 1, 1972, as National Week of Concern for Prisoners of War/Missing in Action, and Sunday, March 26, 1972, as a National Day of Prayer for the lives and safety of these men.

I call upon all the people of the United States to observe this week with such appropriate ceremonies and activities as will stir and sustain widespread concern for the missing men and prisoners, nourish the patient courage of their loved ones, and-above all-hasten the day of their safe return to home and freedom.

IN WITNESS WHEREOF, I have hereunto set my hand this tenth day of March, in the year of our Lord nineteen hundred seventy-two, and of the Independence of the United States of American the one hundred ninety-sixth.

Richard Nixon.

[Filed with the Office of the Federal Register, 11:52 a.m., March 13, 1972]

NoTE: The proclamation was signed in a ceremony at the White House 


\section{Bibliography}

Brunner, J. Acts of Meaning. Cambridge: Harvard University Press, 1990.

Butler, Karen. 2003. Interview by Steven L. Smith. Tape recording. May 24.

Butterfield, Alexander. 2003. Interview by Steven L. Smith. Tape recording. August 12 .

Capen, Richard. 2003. Interview by Steven L. Smith. Tape recording. August 12.

Davis, V. E. The Long Road Home. Washington, DC: Office of the Secretary of Defense, 2000.

Dennison, Sandy. 2003. Interview by Steven L. Smith. Tape recording. April 14.

Denzin, N. K., and Lincoln, Y. S. Handbook of Qualitative Research. Thousand Oaks, CA: Sage Publications, 2000.

Diplomatic Conference for the Establishment of International Conventions for the Protection of Victims of War. Geneva Convention Relative to the Treatment of Prisoners of War, 1949.

Estocin, Marie. 2003. Interview by Steven L. Smith. Tape recording. October 11.

Fontana, A. and Frey, J.H. "The Interview." In Handbook of Qualitative Research, edited by N.K. Denzin and Y.S. Lincoln, 555-672. Thousand Oaks, CA: Sage Publications, 2000.

Galanti, Phyllis. 2003. Interview by Steven L. Smith. Tape recording. April 26.

Garrett, D. L. "The Power of One: Bonnie Singleton and American Prisoners of War in Vietnam." Master's thesis, University of North Texas, 1999.

Geertz, C. The Interpretation of Culture. New York: Basic Books, 2000.

Haig, Albert. 2003. Interview by Steven L. Smith. Tape recording. May 1. 
Bibliography

Halyburton, Marty. 2003. Interview by Steven L. Smith. Tape recording. February 8.

Hart, G. Restoration of the Republic: The Jeffersonian Ideal in 21st Century America. Oxford: Oxford University Press, 2002.

Havel, V. The Power of the Powerless: Citizens Against the State in CentralEastern Europe. Edited by John Keane. Armonk, New York: M.E. Sharpe, Inc., 1985.

Heifetz, R. A. Leadership Without Easy Answers. Cambridge: Belknap Press, 1994.

Heifetz, R. A., and Linsky, M. Leadership on the Line. Boston: Harvard Business School Press, 2002.

___ "Think Politically." Chap. 4 in Leadership on the Line. Boston: Harvard Business School Press, 2002.

_. "Orchestrate the Conflict." Chap. 5 in Leadership on the Line. Boston: Harvard Business School Press, 2002.

Hodder, I, "The Interpretation of Documents and Material Culture." In Handbook of Qualitative Research, edited by N.K. Denzin and Y.S. Lincoln, 703-716. Thousand Oaks, CA: Sage Publications, 2000.

Isaacson, W. and Thomas, E. The Wise Men: Six Friends and the World They Made. New York: Simon and Schuster, 1986.

Keenan, B.M. Every Effort. New York: St. Martin's Press, 1986.

Kiley, F. and Rochester, S.I. Honor Bound: American Prisoners of War in Southeast Asia, 1961-1973. Annapolis: Naval Institute Press, 1998. 
Kingdon, J. Agendas, Alternatives, and Public Policies. Michigan: Harper Collins College Publishers, 1995.

Laird, Melvin. 2003. Interview by Steven L. Smith. Tape recording. June 14.

Lindblom, C. and Woodhouse, E. The Policy Making Process. New Jersey: Prentice Hall, 1993

Martin, Sherry. 2000. Interview by Steven L. Smith. Tape recording. September 1.

McCain, J. Faith of My Fathers. New York: Random House, 1999.

McDaniel, D.H. After the Hero's Welcome: A POW Wife's Story of the Battle Against a New Enemy. Chicago: Bonus Books, 1991.

Merriam, S.B. Qualitative Research and Case Study Applications in Education. San Francisco: Jossey-Bass Publishers, 1998.

Moore, Chloe. 2003. Interview by Steven L. Smith. Tape recording. July 10.

National Archives and Records Administration, National Archives at College Park, College Park, MD. Nixon Presidential Textual Materials, White House Special Files: Staff Member and Office Files.

. White House Central Files: Staff Member and Office Files.

-National Security Council Files: Henry A. Kissinger: Office Files.

—. National Security-Defense (Prisoners) Files: White House Central Files:

ND 18-3.

-. Haldeman Diaries.

Nixon, R. RN: The Memoirs of Richard Nixon. New York: Grosset \& Dunlap, 1978. 
Bibliography

-. Public Papers of the Presidents of the United States: Richard Nixon,

1969. 1 vol. Washington, DC: Government Printing Office, 1971.

Placier, M., Hall, P. M., McKendall, S. B., and Cockrell, K. S. "Policy as the Transformation of Intentions: Making Multicultural Educational Policy." Educational Policy, Vol. 14, No. 2 (2000): 259-289,

Polkinghorne, D.E. Narrative Knowing and the Human Sciences. New York:

State University of New York, 1988.

- Narrative Configuration in Qualitative Analysis. Qualitative Studies in

Education, 8 (1), 5-23.

President, News Conference of January 27, 1969, Public Papers of the Presidents of the United States, Richard Nixon, (1969): 10.

Purcell, B. and Purcell, A. Love and Duty. New York: St. Martin's Press, 1992.

Riessman, C.K. Narrative Analysis. Newbury Park: Sage Publications, 1993.

Robertson, Jenny Connell. 2003. Interview by Steven L. Smith. Tape recording. June 25 .

Rubin, H.J. and Rubin, I.S. Qualitative Interviewing. Thousand Oaks: Sage Publications, 1995.

Rutledge, H. and Rutledge, P. In the Presence of Mine Enemies. New Jersey:

Fleming H. Revell, 1973.

Schattschneider, E. E. The Semisovereign People: A Realist's View of Democracy in America. Forth Worth: Harcourt Brace Jovanovich College Publishers, 1975.

Silver, J. and Gottlieb, L. Limbo. New York: Viking Press, 1972. 
Singleton, Bonnie. 2003. Interview by Steven L. Smith. Tape recording. September 6-7.

Stark, Shirley. 2000. Interview by ««GreetingLine»». Tape recording. September 9.

Stockdale, J. B. and Stockdale, S. In Love and War: The Story of a Family's Ordeal and Sacrifice During the Vietnam Years. New York: Harper and Row, 1984.

Stockdale, Sybil. 2000. Interview by Steven L. Smith. Tape recording. June 7-8, 16-17, and October 6.

Stratton, Alice. 2003. Interview by Steven L. Smith. Tape recording. February 10.

Taylor, L. Honorbound. New York: Franklin Watts, 1988.

Tierney, W.G. "Undaunted Courage." In Handbook of Qualitative Research, edited by N.K. Denzin and Y.S. Lincoln, 537-553. Thousand Oaks, CA: Sage Publications, 2000.

US Congress. Congressional Record. $91^{\text {st }}$ Cong., 2d sess., 1970. Vol. 116, pt 6 and pt 10 .

Van Manen, M. Researching Lived Experience. London: State University of New York, 1990.

Winn, Mary. 2003. Interview by Steven L. Smith. Tape recording. June 20. 
Let's not allow having been a POW or a member of a POW's family

to become equated with Motherhood to the extent that we become exponents of the policy which proposes that no amount of money is too much to spend for research to prevent future family chaos and heartache if we have future American POW's. The two conditions are inseparable. Keep what can realistically be accomplished in its proper perspective. Continue the medical follow-up for those who were POW's, assist the MIA families by giving supportive help in the areas they find supportive, put all the information that has already been collected onto microfilm, put it in a drawer, close the drawer, and hope to God we never have to open it again.

\section{Sybil Stockdale}

"My Philosophy about the Center for Prisoner of War Studies" 